\section{DÜBLIN}

Books

AFIS (Association of Franco-Irish Studies)

Publications

\title{
Cultural Perspectives on Globalisation and Ireland
}

\author{
Eamon Maher \\ Technological University Dublin, eamon.maher@tudublin.ie
}

Follow this and additional works at: https://arrow.tudublin.ie/afisbo

Part of the Arts and Humanities Commons

\section{Recommended Citation \\ Maher, Eamon, "Cultural Perspectives on Globalisation and Ireland" (2011). Books. 6. \\ https://arrow.tudublin.ie/afisbo/6}

This Book is brought to you for free and open access

by the AFIS (Association of Franco-Irish Studies)

Publications at ARROW@TU Dublin. It has been

accepted for inclusion in Books by an authorized

administrator of ARROW@TU Dublin. For more

information, please contact arrow.admin@tudublin.ie,

aisling.coyne@tudublin.ie,

gerard.connolly@tudublin.ie.

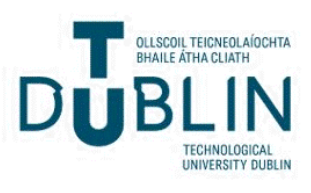


Cultural Perspectives on Globalisation and Ireland 


\section{Reimagining Ireland}

Volume 5

Edited by Dr Eamon Maher

Institute of Technology, Tallaght

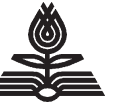

PETER LANG

Oxford $\bullet$ Bern $\bullet$ Berlin $\bullet$ Bruxelles $\bullet$ Frankfurt am Main $\bullet$ New York $\bullet$ Wien 


\section{Eamon Maher (ed.)}

\section{Cultural}

Perspectives on Globalisation and Ireland

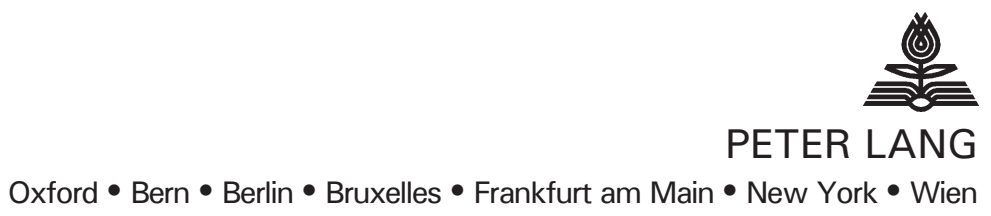


Bibliographic information published by Die Deutsche Bibliothek Die Deutsche Bibliothek lists this publication in the Deutsche Nationalbibliografie; detailed bibliographic data is available on the Internet at $<$ http://dnb.ddb.de $>$.

A catalogue record for this book is available from The British Library.

Library of Congress Cataloging-in-Publication Data:

Maher, Eamon.

Cultural perspectives on globalisation and Ireland / Eamon Maher. p. cm. -- (Reimagining Ireland ; 5)

Includes bibliographical references and index.

ISBN 978-3-03911-851-9 (alk. paper)

1. Culture and globalization--Ireland--History--20th century. 2.

Globalization--Social aspects--Ireland. 3. Ireland--Civilization--20th century. 4. Globalization in literature. 5. Literature and globalization--Ireland--History--20th century. 6. English literature--Irish authors--History and criticism. 7. English literature--20th century--History and criticism. I. Title. DA959.1.M25 2009

303.48'2417--dc22

\section{9}

ISSN 1662-9094

ISBN 978-3-03911-851-9

Cover image: collage created by Paul Butler.

(C) Peter Lang AG, International Academic Publishers, Bern 2009 Hochfeldstrasse 32, CH-3012 Bern, Switzerland info@peterlang.com,www.peterlang.com,www.peterlang.net

All rights reserved.

All parts of this publication are protected by copyright. Any utilisation outside the strict limits of the copyright law, without the permission of the publisher, is forbidden and liable to prosecution. This applies in particular to reproductions, translations, microfilming, and storage and processing in electronic retrieval systems.

Printed in Germany 


\section{Contents}

Foreword vii

FINTAN O'TOOLE

Introduction

EAMON MAHER

PART I: Globalisation and Irish Society

I. Inside Out: Time and Place in Global Ireland II MICHAEL CRONIN

2. The Global Irish Spirit

CATHERINE MAIGNANT

3. In at the Death: The French Press and the Celtic Tiger GRACE NEVILLE

4. Negotiating the Self: The Spectral Mobile Subject EUGENE O'BRIEN

5. Globalisation, Vulnerability and the Return to Religion:

Reflections from the Irish Experience PEADAR KIRBY

6. The Global is Personal TOM INGLIS 
PART II: Literary Perspectives on Globalisation and Ireland

7. Contemporary Irish Fiction and the Transnational Imaginary 133 ANNE FOGARTY

8. 'Root and Routes': Home and Away in Friel and Heaney 149 ALISON O'MALLEY-YOUNGER AND TOM HERRON

9. Irish Theatre and Globalisation: A Faustian Pact? PATRICK LONERGAN

Io. 'Coming of Age' (and other Fictions of Globalisation) in Three Novels by Seamus Deane, Roddy Doyle and Patrick McCabe I9I WILLY MALEY

II. 'The Universal is the Local without Walls' John McGahern and the Global Project EAMON MAHER

Notes on Contributors 233

Index 


\section{Foreword}

FINTAN O'TOOLE

A long time ago, in a galaxy far, far, far away, the Communist Party in each part of the Soviet empire was given a 'brotherly working-class party' from a benighted capitalist country to look after. The special protégé of the Soviet Socialist Republic of Lithuania's Communist Party was Ireland, so the general secretary of the Communist Party of Ireland, Michael O'Riordan, was a regular guest at the official seaside town of Palanga. On almost every visit, he gave an interview to the state newspaper. He would stress the similarities of Lithuania and Ireland, with their comparable area and population size. But, recalled the Lithuanian writer Simonas Daukantas, his recurring theme was, 'How much Ireland could learn from Lithuania's non-capitalist way of development' and that 'Lithuania shows what would be Ireland's achievements if the country went socialist.'

By 2005 , there were 70,000 Lithuanian immigrants working in Ireland. Lithuanian students were being told 'How much Lithuania could learn from Ireland's free market way of development' and that 'Ireland shows what would be Lithuania's achievements if the country went capitalist'. The Lithuanians were urged to create a Baltic Tiger in conscious emulation of the Celtic Tiger. And by the end of 2008 , the Lithuanian government was running job fairs in Dublin, offering the migrants a way out of the imploded Irish dream. ${ }^{2}$

I S. Daukantas, review of Lee Komito, The Information Revolution and Ireland: Prospects and Challenges (Dublin: University College Dublin Press, 2004). In Information Research, IO (3), 2005, review no. Ri7i. Available at: http://informationr.net/ir/ reviews/revsi7 I.html.

2 Ronan McGreevy, 'Lithuanian immigrants urged to come home', in The Irish Times, 22 November 2008. 
It is tempting - and not entirely wrong - to see this circular journey as a small parable of the dislocations and ironies of Ireland's experience of postmodern globalisation in the late twentieth and early twenty-first centuries. Yet, by stressing the newness and strangeness of that experience, we can oversimplify the Irish past. Lithuanian migration into Ireland, for example, did not begin in the late 1990 s, when the Celtic Tiger was a magnet and a model. It began in the I88os, when anti-Jewish pogroms followed the assassination of Tsar Alexander II. Jews from Lithuania, indeed largely from the single shtetl of Akmijan, formed the core of the Jewish communities of Dublin, Cork, Belfast and Limerick. That single community produced such important figures of late twentieth-century Irish culture as the editor and novelist David Marcus, the film maker Louis Marcus, the politician and intellectual Gerald Goldberg and the director and documentary maker Louis Lentin. In the Jewish cemetery that was literally over the wall from where I grew up in Dublin, there were gravestones marked with inscriptions like 'a Good Woman of Akmijan'.

Amnesia has overtaken Akmijan: it is now called Akmeme and all trace of its Jewish community has been obliterated, first by the pogroms, then by the Holocaust. Amnesia has also overtaken the Lithuanian Jewish communities of Irish cities, the Little Lithuanias long gone, the memory of their existence rapidly fading. ${ }^{3}$ We must bear in mind that understanding globalisation in the Irish context is as much a task of remembrance and recovery as it is of encountering the new.

The paradox of globalisation is that it is at once a process of cultural homogenisation (the aim, as the Irish capitalist Tony O'Reilly put it, is to make all cultures alike so as to 'generate the cosmopolitan aspirations best satisfied by global brands ${ }^{\prime 4}$ ) and a process that is experienced in ways that highlight the specificity of every culture it touches. In the Irish case, that specificity lies, not in genuine newness, but in a sense of what might be

See Dermot Keogh, Jews in Twentieth Century Ireland (Cork: Cork University Press, I998), passim.

4 See Fintan O'Toole, The Ex-Isle of Erin: Images of a Global Ireland (Dublin: New Island Books, 1997), pp. 129-30. 
called dislocated continuity. What I mean by this is the sensation of experiencing the same things in a different spatial and temporal context. Within this sensation, there was a constant slippage between apparent opposites new and old, history and current affairs, home and abroad, familiarity and estrangement. Put simply, between 1990 and 2007, Ireland experienced as newness and postmodernity what Irish people as emigrants had experienced as modernity in the nineteenth and early twentieth centuries.

This experience has to be distinguished from the obvious ways in which globalisation itself is not a new experience for Ireland. As far back as the late Iron Age, Irish elites were adopting fashionable European styles (so-called Celtic art) to distinguish themselves from their humbler fellow countrymen and women. Since then, we can distinguish three huge waves of globalising influences. There was Christianity, with its revolutionary privileging of the universal over the local and stunning new communications technology (literacy). There was imperialism, experienced both through the forcible incorporation of Ireland in the burgeoning British Empire and through the deployment of Irish people in the projection of imperial power. (This process was as complex and multi-dimensional as anything experienced in the twenty-first century. As early as the 1750 s, for example, we find Irish men killing each other in the forests of the North American frontier, some as 'French' soldiers, some as 'English' troops and all therefore as suspect and unstable elements in a supposedly clear dichotomy.)

And there was consumerism. Global trade may have expanded and contracted in different phases since the eighteenth century, but it affected Irish culture in the most profound ways. Again, as early as 1745, we can find the Irish trader William Johnson selling Chinese vermillion, wrapped in convenient little packages, to Iroquois warriors for use as war-paint - an example of the pure globalised consumerism that we tend to associate only with late modernity. ${ }^{5}$ At home the nineteeth-century consumer revolution affected Ireland at least as much as any other part of western Europe. By the early twentieth century, for example, even the inhabitants of the remote

5 See Fintan O'Toole, White Savage: William Johnson and the Invention of America (London, Faber, 2005), pp. 54-5. 
Blasket Islands, held up as examples of Gaelic pre-modernity, were part of a consumer culture. 'I was a grown man before tea was known ...' recalled Tomás O'Crohan in The Islandman (1937). 'But the tune has changed altogether in the matter of food for a long time now. We have wheat-flour in these days, and tea and sugar.' 'We had tea and sugar to spare', recalled his son Seán O'Crohan, 'because we used to bring tea back to the Blasket in pounds, and sugar by the stone weight."

James Joyce's reconstructions of Dublin in the early twentieth century are already awash with the virtual realities of a global consumer culture in which Otherness has been thoroughly commodified and objects are instinct with the desires they provoke. From the enchantment cast over the narrator of 'Araby' by the very name of the commercial bazaar that is selling Eastern promise, to the Turkish Delight with which Miss Devlin in 'A Mother' sublimates her romantic desires, from the travel books on China that are on Leopold Bloom's shelves to the exotic racing cars that spin through the Dublin suburbs in 'After the Race', and from the Wild West stories and detective novels that have formed the imaginations of the boys in 'An Encounter' to the lush fantasies of Molly Bloom's light opera songs, the culture Joyce presents is one that is already profoundly shaped by advertising, the mass media and consumerism.

If these globalising forces have been at work for so long, how can we say that the experiences of Irish culture since 1990 have been in any way different? Yet, even while avoiding the trap of inventing some kind of 'authentic' and unmediated past, we do need to grasp the specifics of recent years. Over this period, after all, Ireland did not merely become more globalised. It became, according to the A.T. Kearney/Foreign Policy magazine Globalisation Index, the most globalised society in the world in 2002 , 2003 and 2004. (Ireland's ranking dropped by 2007 , but it is still ranked fifth, well ahead of countries like the United States and Britain.) Ireland Press, 2000), p. 32.

7 Seán O'Crohan (trans. Tim Enright), A Day in Our Life (Oxford: Oxford University Press, 1993), p. 29. 
was both the most extreme example of globalisation and a global model for apparently successful adaptation to the twenty-first-century economy. There is a qualitative difference between being affected by globalisation, as Ireland was for previous centuries, and being its poster child, as it became in the recent boom years. It would be surprising if this difference did not manifest itself in cultural terms. But, given the fractal geometry of Irish culture, its fracture and sedimentary nature, it would be equally surprising if the difference was expressed in mere novelty.

This is where the concept of a dislocated continuity may be useful. There is a sense in which both time and space acquired the feeling of being, in that favourite Irish paradox, 'the same only different'. The sense of space, at one level, seemed to become vastly more coherent. With the virtual ending of involuntary mass emigration, and the settlement of the Northern Ireland conflict, the Republic of Ireland held together as both an inhabited and a political space in a way that it had arguably never done before. Politically, the state was both successful and, with the removal of the constitutional claim on Northern Ireland, securely bounded. As an inhabited space, it could be imagined as a genuine entity. The long separation - due to mass emigration - of 'Ireland', the place, and 'Irish', the people, seemed to be definitively overcome. Spatially, Ireland was apparently settled.

In temporal terms, the same thing was apparently true. In the idiotic phrase that became one of the great clichés of public discourse, we were 'putting the past behind us'. This was true of Northern Ireland, in which political and sectarian divisions were allegedly transcended in the Belfast Agreement. It was also true of the economic miracle of the boom in which a past of underdevelopment and failure was banished. There was a process of temporal alignment in which Ireland ceased to be an anomalous rearguard of western European progress and streaked into the vanguard. The future of which the patriot dead had dreamed had finally arrived - we were it.

And yet, these apparent continuities of space and time - becoming a 'normal' country with a 'normal' history in which the past stayed past - were in tension with the effects of the same process of extreme globalisation that had made them possible. The apparently settled sense of space was no such thing. What ought to accompany the end of mass emigration - the feeling of being 'at home' - was conspicuously absent. At the simplest physical 
level - home as house - a manic property boom disrupted any clear sense of belonging. It was not just that one in six of the entire national housing stock was built between $200 \mathrm{r}$ and 2006 , creating a very real sense of physical change. It was also that, in a haunting example of the same things being experienced differently, emptiness continued to be a central aspect of Irish housing. Before the 1990 s and the boom, empty houses were a product of emigration and a symbol of poverty. In the boom years, we actually manufactured empty houses as a symbol of demented riches. In 2006 on census night, 266,000 homes were classified as vacant. In County Leitrim, an area long denuded by emigration, almost a third of all houses were empty - not because of emigration, but because of purposeless building. The meaning of vacancy had fundamentally changed, but its reality persisted.

This spatial confusion extended from the micro-level of empty houses to the macro-level of uncertainty about Ireland's place in the world. The question asked by a character in Sebastian Barry's play Prayers of Sherkin - 'Do you not feel that this island is moored only lightly to the seabed, and might be off for the Americas at any moment?' - took on a peculiar relevance. Because Ireland's hyper-globalisation had been driven largely by American investment, it generated a belief that Ireland was not really European at all, but existed, imaginatively, at least a thousand miles further west in the Atlantic than its physical co-ordinates would imply. As Mary Harney, then Tánaiste, put it: 'Ireland is spiritually closer to Boston than Berlin'.

And as well as being further west, Ireland was also further south. In its boom years, it ceased to be a rain-soaked, fog-bound, windswept northerly island and shifted to a sun-kissed Mediterranean latitude. Pavement cafes and outdoor seating proliferated. People wore fewer clothes, as if the cold and the wet could be defied by mere denial. And the imagery of the new Ireland was bathed in sunlight. As the property editor of The Irish Times, Orna Mulcahy, noted of one the iconic (doubly iconic in being unbuilt) developments of the boom years, a towering complex in the Dublin suburb of Ballsbridge: 
I dug out the architects' drawings from the bottom of a heap under my desk and yes, there it was: sunshine, flooding the imagined plazas and courtyards and bouncing off the glass of towering apartment blocks. Pert-breasted women strolling around in T-shirts and sun glasses. Even the underground shopping mall appeared to have an abundance of sunlight spilling in via a mini Eden project jutting up at ground level, filled with palms, orchids and cacti. The central piazza, with I4- and I5-storey buildings all around, had the baked ochre look of a Las Vegas resort slumbering in 100 degree heat, with office windows above flung open ... On the property developer's compass, you see, there is no north. Invariably, their computer-generated plans for housing or office schemes are forever drenched in sunshine, no matter what the aspect. High noon type shadows are cast by computer generated people... the vast majority of balconies built during the boom faced south - even the many that actually looked due north and enjoyed direct sunlight about once a year, Newgrange-style, on June 2ist at four in the morning. ${ }^{8}$

These strange shifts of space were matched by a collapse of linear temporal sequencing. The apparent arrival of a 'normal' history in which the past was where it should be - 'behind us' - was deceptive on two levels. Firstly, the process of secularisation and of the disruption of traditional authority that accompanied extreme globalisation, led to an opening of the past in which history became current affairs. The exposure of the scandals of child abuse within the Catholic Church and the multiple tribunals of inquiry into the corrupt relationships of business and politics gave a decidedly retrospective cast to Irish culture in the boom years - a mould into which a great deal of the contemporary literature continued to fit. Secondly, there was the return of the repressed in the form of inward migration. The rapid change from emigration to immigration and the quick shift from a society with minimal inward migration to one in which I2 per cent of the workforce was born outside Ireland affected the sense of spatial boundaries, but it also disrupted any linear notion of time. Migrants disturbed the apparent settlement of boom-time Ireland because they were both new and old. They were, on the one hand, the most visible sign - and through their multiple languages, sound - of radical globalisation. They literally

8 Orna Mulcahy, 'Abysmal in the Gulag after sun and fun of boom days', in The Irish Times, 6 February 2009. 
embodied a major break with the past. Yet, on the other hand, they were also old. They were us - twenty years, or fifty years, or 150 years before. Their presence created overlapping realities. In one, Ireland was still an emigrant society, demanding decent treatment for those who left Ireland for England in the 1950 s or who went as undocumented workers to the United States in the 1980 s. In another, it was an arrogant, resentful host country in which the words 'economic migrant' formed a term of abuse.

And in this double reality, time refused to go in straight lines. For what the Irish in Ireland were experiencing as new - rapid urbanisation, multiculturalism, the need to make one's way in a polyglot and physically unfamiliar society - was a recapitulation of the experiences of their own ancestors. The diasporic life was now lived at home - a logical outcome of the economic reversal in which, instead of Irish labour moving towards American capital, American capital had moved towards Irish labour. The sense of estrangement felt by generations of emigrants could now be felt without actually going anywhere.

All of this is so recent, and may have been so confusingly evanescent, that it has not yet been fully processed by cultural, intellectual and artistic reflection. And yet there is a sense that it cannot be fully experienced, and therefore collectively owned, until that reflection has taken place. With the shock of the return of all the other repressed fears - emigration, mass unemployment, failure - there is no better time for that process to begin and no better place than in the subtle, alert and probing essays which follow. 


\section{Introduction}

EAMON MAHER

It is a truism to state that in the space of a few decades Ireland became one of the most globalised societies in the Western world. The full ramifications of such a transformation for traditional Irish communities, religious practice, economic activity, literature and the arts, are as yet unknown. What we do know is that Ireland's unthinking embrace of globalisation has at times had negative consequences. Unlike some other European countries, France and Germany in particular, Ireland eagerly and sometimes recklessly grasped the opportunities for material advancement afforded by the global project. The French saw more clearly than most how globalisation (which they associated with the Americanisation or $\mathrm{McD}$ onaldisation of the universe) posed a threat to their cultural specificity. The fact that English became the lingua franca of commerce as well as the dominant language used in the ultimate globalising technology, the internet, made the French wary of what lay ahead for their language and culture. They spoke out vociferously against the pervasive use of English and the uniform acceptance of unbridled capitalist ideology. They put measures in place to support things like French literature and cinema and asserted their cultural uniqueness whenever the opportunity arose.

Their independent stance had broader ramifications when in 2003 , on the eve of the outbreak of the war in Iraq, the then French Minister for Foreign Affairs, Dominique de Villepin, strongly questioned the wisdom of waging war without just cause at the Security Council of the United Nations. This opposition was a source of resentment in the United States for some time: they argued that they were engaged in a global war on terror 
and that it was the duty of all 'civilised' ${ }^{\text {' }}$ nations to support them. French wine and cheese products were subsequently boycotted in America, with disastrous consequences for these key industries, but the French held firm on their opposition to the war.

The Irish government, on the other hand, aware of the extent to which economic prosperity was strongly linked to the presence here of American multinationals like Intel, Dell and Hewlett Packard, who were attracted initially by a very favourable corporate tax regime, were quick to offer Shannon Airport for the refuelling of American aircraft on their way to Iraq or, some would argue, for the rendition of prisoners en route to Guantanamo Bay. This gesture, which was portrayed as a signal of goodwill to our 'special friend' and guarantor of our economic progress, did not prevent the loss of over $\mathrm{I}, 000$ jobs in Dell in 2009 as the company moved its manufacturing operation from Limerick to low-wage Poland. Dell could do this because globalisation enables a swift setting up of new businesses and their equally rapid winding up when a better deal presents itself elsewhere. Multinationals are primarily interested in profit and are not controlled by national governments. Gratitude and loyalty do not feature prominently in their game plan in the way in which the Irish government believed.

Likewise, commentators who warned that Ireland's unhealthy dependency on foreign multinationals, the financial services, construction and the property boom - all manifestations of the effects of globalisation in Ireland - could ultimately lead to financial ruin, were treated like pariahs. They were accused of talking Ireland into a recession, of being kill-joys, and of having no concept of how a modern open economy works. Undoubtedly they would have preferred their predictions to have proved unfounded as the current recession has had negative consequences for everyone in the country, including the commentators. Writing in 2002, Peadar Kirby questioned the basis of the Irish economic miracle. At the heart of his critique was the conviction that it was the economic and political elites who were benefiting inordinately from the new-found prosperity: time. 
The highly positive reading given these transformations can only be understood as deriving from a fundamental misunderstanding - namely that the interests of the whole of Irish society are equated with the interests of those elites who are benefiting from this newly invented Ireland. But this reading has also taken on a power in its own right, promoting economic growth as an end in itself and equating social success with the enrichment and conspicuous consumption of wealthy elites. This has the effect of dispossessing those who do not share in this success, and who are therefore redefined, not as citizens whose rights and needs can make justifiable claims on society, but as outside observers who can only look on in envy at the growing takeover of society by these elites. ${ }^{2}$

This is an insightful summation of what occurred in the years referred to as the Celtic Tiger. Statements to the effect that the enrichment of Irish society was undemocratic, with a small minority benefiting inordinately from greater access to capital and a regulatory system that relied on a light touch, were seriously frowned upon by the ruling elite and those to whom the criticism was attributed were excoriated. The last months of 2008 and the beginning of 2009 brought to light the existence of a 'cosy cartel' within corporate Ireland, where banks and other lending agencies vied with each other to offer sweet deals to property developers and other businesses. The result is a crippling amount of toxic debt that the government and tax payers have to underwrite. In spite of protestations to the effect that we are caught up in what is in effect a 'global problem', most people know deep down that unbridled greed and a lack of efficient regulation have meant that we are more exposed than our more prudent European partners. As corrective measures come hailing down, with a promise of more severe cut-backs to come, with unemployment having exceeded ro per cent for the first time in a number of decades, the realisation is beginning to sink in that the boom years, instead of closing the gap between rich and poor, have only accentuated it.

An examination of why we were so enamoured with capitalism and its global manifestations must take into account the desire of many Irish men

2 Peadar Kirby, 'Contested Pedigrees of the Celtic Tiger', in Kirby, Gibbons and Cronin (eds), Reinventing Ireland: Culture, Society and the Global Economy (London: Pluto, 2003), pp. 2I-37, pp. 32-3. 
and women to see the demise of what they viewed as a regressive, Churchdominated society which was viewed as a barrier to social and material advancement. Joe Cleary makes the following observation:

However one makes sense of the last century, it can hardly be disputed that most of the people on the island of Ireland now are materially better off and have more social rights and liberties than had their antecedents either when the two states were founded in the early 1920 s or even in the early 1960 s. This, surely, must be the definitive litmus test of the generally 'progressive' character of the modes of capitalist modernization supervised by the ruling classes in Northern and Southern Irish society in recent decades? ${ }^{3}$

While accepting that progress has been made on a number of fronts, Cleary does not impute the dawning of this new era to capitalist modernisation, but rather to 'radical movements from below.' To the defenders of capitalism who claim that the working classes are now better off than the lower middle class of former times, Cleary counters:

But this ignores the economic logic of late consumer capitalism, which requires a mode of production that generates not only affluence but also endemic frustration and dissatisfaction. Only by manufacturing a perpetually dissatisfied sense of want can consumer capitalism sustain the continual demand for the unlimited goods it needs to sell in order to reproduce itself. ${ }^{4}$

This 'dissatisfied sense of want' is what best characterises Irish society in the past number of years. The Church had been one of the main lobby groups to speak out against unbridled consumerism, but as its role as moral arbiter dissipated in the mists of the mishandling of child abuse scandals, there was no real powerful voice left to represent the plight of those whom the Celtic Tiger had passed by. In addition to the greatly diminished influence of the Catholic Church, the last two decades witnessed the election of the first female President of Ireland, Mary Robinson, the decriminalisation of homosexuality between consenting adults, the liberalisation of artificial

3 Joe Cleary, 'Introduction', in Outrageous Fortune: Capital and Culture in Modern Ireland (Dublin: Field Day Publications, 2007), p. 9. 
means of contraception, the legalisation of divorce, the emergence of a multicultural Ireland. The country has witnessed change on a scale never before witnessed in such a short period. The sociologist Tom Inglis sums up the transformation of Irish society very well when he notes:

What was crucial during the second half of the twentieth century was how, for some people, that sense of difference moved from a predominantly Catholic culture to one of commodity capitalism. Instead of realising ourselves through the language of the Church and its teachings and practices, we gradually switched to realising ourselves through the language of the market and its teachings and practices.

As more and more money poured into the country, an inordinately large chunk of it came into the possession of a privileged few who made massive fortunes and were allowed generous tax exemptions on the premise that they were generating wealth and creating employment. Very few questioned what was really happening in Irish society: most were too busy indulging in an orgy of consumer spending to cast a nostalgic glance to what was being lost. Anthony Giddens argues that globalisation takes a hold so quickly that people fail to notice what is happening around them:

We live in a world of transformations, affecting almost every aspect of what we do. For better or worse, we are being propelled into a global order that no one fully understands, but which is making its effects felt upon all of us. ${ }^{6}$

The speed with which massive global financial transactions can now take place has no parallel in the past. The world has become a smaller place as technology becomes ever more sophisticated. Young people in Beijing are dressed similarly to those in Paris, London, New York or Dublin. They tend to listen to the same type of music on the same iPods and congregate in McDonald's or Kentucky Fried Chicken where they drink Coca Cola or Pepsi. A uniform global culture has taken hold and Ireland has been prominent in adopting its various manifestations. 
This book, largely the fruit of two workshops organised under the auspices of the Humanities Institute of Ireland at University College Dublin and the National Centre for Franco-Irish Studies at the Institute of Technology, Tallaght, explores how globalisation has affected Ireland and provides a unique cultural perspective on the phenomenon. Following the thought-provoking Foreword by Fintan O'Toole, Part I concerns itself with manifestations of globalisation in Irish society. Issues such as time and place, spirituality, religion, politics, cultural theory and the media are addressed with a view to assessing the path that has led Ireland to its current state. The need 'to analyse how being turned 'inside out' by changing relationships of time and space affects in profound ways the human capacity to dwell in any given place', is emphasised by Michael Cronin. The lens of the French print media is employed by Grace Neville to offer an external glance on the Irish engagement with globalising forces, with conclusions that show that the formerly close relationship between the Celtic cousins has changed significantly. The section concludes with Tom Inglis' discussion of how the global is also highly personal. Inglis underlines the necessity for our understanding of globalisation to 'move beyond the orthodoxy of seeing it primarily as an economic, political and social process. It is also fundamentally a cultural one.'

Part II discusses contemporary Irish literature's attempts to come to grips with a rapidly changing social context. Authors such as Roddy Doyle, Colum McCann, Brian Friel, Seamus Heaney, Conor McPherson, Seamus Deane, Patrick McCabe and John McGahern are evoked to telling effect. Willy Maley argues that 'we ought not be too hasty in our efforts to be done with the past' and urges that a note of caution be sounded in relation to 'an over-optimistic attitude to globalisation.' The writers mentioned are cognisant of the dangers and try to suggest new ways of envisioning existence through their art. Eamon Maher relates how the late John McGahern liked to quote the Portuguese writer Miguel Torga's comment that 'The universal is the local without walls' and shows how McGahern's concentration on the small area of Leitrim-Roscommon allowed him to make of one small place an everywhere. Irish fiction writers are clearly sensitive to the winds of change that have come with the advent of immigration (Anne Fogarty and Willy Maley touch on the work of Roddy Doyle, who deals 
with this theme in some of his more recent work), the decline of organised religion, death, the importance of place (Friel, Heaney and McGahern are all dealt with in this context) and the various chapters reflect the concerns of writers on these matters.

I have not considered it necessary to summarise each individual contribution. It should be clear from the chapter headings which approaches have been adopted by the various authors. What I hope emerges from the collection is an enriching panoply of cultural perspectives on globalisation and Ireland. A sincere word of thanks to all the contributors for their unstinting cooperation during the elaboration of this project: they were really a pleasure to work with. Fintan O'Toole also deserves special mention for agreeing to write an illuminating Foreword to what I hope will be a worthwhile commentary on one of the most pressing issues in contemporary Irish society. 



\section{PART I}

Globalisation and Irish Society 



\section{Inside Out: Time and Place in Global Ireland}

MICHAEL CRONIN

The piper, it is said, calls the tune but in Ireland he is often expected, in addition, to explain it. The great piper and folklore collector Séamus Ennis was no exception and he frequently prefaced his tunes with an account of their origin. One such tune was Cornphipopa na Siog or the Fairies Hornpipe and Ennis's story went as follows. A man returning home from a wedding loses his way and if that happens to any of you, you have but to take off your coat and turn it inside-out and put it on again and you'll find your way home alright.' The wedding reveller does this and he ends up three fields away from his own house. At the bottom of the long field in which he finds himself there is a fairy host dancing to music played by a piper. Listening to the music he falls asleep and when he awakes next morning and goes home to tell people what he saw, no one believes him. It was only when they hear him play the tune he picked up from the fairies on the pipes that they decide he was not making it up. Thus, ever afterwards the tune is known as the 'Fairies Hornpipe'.

In a twinkling, the wedding guest is transported to the vicinity of his house. The vignette from Irish folklore anticipates the phenomenon of space-time compression in modernity where successive generations find getting people and information from one point to another takes progressively less time. In Ennis's story, losing your way is also about finding your way but finding your way involves change, transformation, inversion ('you have but to take off your coat and turn it inside-out'). The coordinates in the musical parable are space and time. What happens when trying to find out where you are might involve turning your world upside down before the sceptical welcome of homecoming. In this essay, we will explore the 
consequences for contemporary Ireland of changes in perceptions and experiences of place and time as they are experienced in late modern Ireland.

The Czech novelist Milan Kundera in his first French-language novel La Lenteur (1995), published in English as Slowness (1996), notes that when people try to remember, they slow down and when they want to forget, they accelerate. He describes a man walking down the street:

At a certain moment, he tries to recall something, but the recollection escapes him. Automatically he slows down. Meanwhile, a person who wants to forget a disagreeable incident he has just lived through starts unconsciously to speed up his pace, as if he were trying to distance himself from a thing too close to him in time. ${ }^{2}$

For Kundera, place is bound up with pace. The more you seek to get away from a place, the faster you go. Conversely, the slower you go, the more you become aware of place, and more particularly, the more you become aware of the place of memory. Mnemosyne for the writer is the deity of deceleration. It is not surprising then that when we go to look at narratives from contemporary Ireland, an exploration of place is going to involve the manipulation of time.

\section{Muintir}

In order to provide a properly stereoscopic view of a place at a particular moment the essay will begin with two prose narratives, one in English and one in Irish, both published in 2007 and both dealing with the lives and characters of suburban Dubliners. The novels are The Gathering by Booker Prize winner Anne Enright and Cnoc na Lobhar by Lorcán S. Ó Treasaigh. In Enright's novel the death in England of a family member, Liam, brings the family together for his funeral, a story narrated principally by his sister

2 Milan Kundera, Slowness. Translated by Linda Asher (London: Faber, 1996), p. 34 . 
Veronica who is responsible for the repatriation of his body. The protagonist of Ó Treasaigh's work, Labhrás, is in an old folks' home awaiting in bitter recrimination the inevitable end stop of death. Death and old age bring with them their own rhythms. Both works, then, are studies in the effects of a change in tempo, memories bustling in as a fast-paced globalised Ireland is bracketed by grief and loss.

A common preoccupation for both Labhrás and Veronica is how to prevent a gathering in from becoming a falling out. That is to say, as they find time to think about the place in which they live and have lived, they are forced to think about the people who have shared that place with them, whether it be in the present or in the past. Labhrás, an old school nationalist, who has remained all his life deeply committed to the cause of the Irish language, sees his ideal of a shared place initially in expansive, communitarian terms. The Ireland that he has dreamed of is a collective enterprise:

Roinn siad saol is teanga, brón is áthas, gliondar is briseadh croí, sheas siad le chéile ag baisteadh is pósadh, thóg ualach a chéile idir chliabhán is chónra agus bí cinnte má bhain an saol tuisle asat ar an mbóthar go mbeadh lámh do chomharsan faoi do chloigeann sula mbuailfeá le talamh é. ${ }^{3}$

(They shared life and language, sadness and happiness, joy and heartbreak, they stood side by side at baptisms and weddings, they supported each other from the cradle to the grave and you can be sure that if life did you a bad turn there would always be a helping hand to stop your fall. [My translation.])

'Muintir' is the term that is used by Labhrás to describe this cooperative community of equals who were united at an undetermined moment in the past by their common condition of being inhabitants of a particular place and remaining committed to the language of their forebears. As the story of Labhrás's life unfolds, however, the semantic range of the term contracts and Labhrás, up late drinking in the silence of his fractured household, contemplates his present with contempt: 
Seo é an teach agam, seo iad mo mhuintir agus seo é mo shaol, a bhí mé ag ceapadh sular thit mo chodladh orm sa tolg agus mé ag brionglóidí ar a bheith in áit éigin eile ar thaobh eile an domhain seachas a bheith i m'aonar i ngarraí leathscoite i mo shaoránach i measc na saoránach leathscoite ag casadh na cré ar mhaithe lena casadh go dté mé lá éigin inti, cré dhubh mo mhéine, cré fhuar na cille. (p. 142)

(This is my house, this is my family and this is my life, I was thinking before I fell asleep on the couch and I dreaming of being somewhere else on the other side of the world instead of being on my own in my semi-detached garden, a citizen among the other semi-detached citizens, turning the earth for the sake of turning it until the day when I will descend into it, the black earth of my desire, the cold earth of the graveyard. [My translation.])

'Muintir' is no longer the extended family of an imagined past but the biological family of his living present. What is apparent in the narrative is that the space he has shared with members of his own family has become a place of intolerable strife as his ideological certainties inure him to a world that is changing and to personalities and values which are evolving. As time slackens, Labhrás begins in effect to take stock of the collapse of this imagined community of place and of the fallout of casting his own 'muintir' in the image of an Ireland that was not to be.

Anne Enright's heroine Veronica is similarly troubled by how families fail to live up to their own promise. Not only does she feel temporarily estranged from her own husband and children, but the experience of making the arrangements for Liam's burial makes her realise the extent to which her own experience of family growing up has always been deeply conflicted. Her own memories of relationships between parents and children in late modern Ireland on the eve of the economic boom are avowedly unromantic:

Back in Belfield, my best friend Deirdre Moloney had just been thrown out by her mother for nothing at all: a very low-key sort of girl, she only ever had sex twice. Children were being chucked out all over Dublin. All our parents were mad, in those days. There was something about just the smell of us growing up that drove them completely insane. ${ }^{4}$ 
More damaging evidence of dsyfunctionality in families in both novels comes from hidden tales of abuse by close members of a family circle. One could argue that the unhappy Irish family is such a staple of late twentiethcentury Irish fiction and memoir that its repeated appearance is more wearisome than illuminating. However, it is worth considering the collapse of a certain idea of muintir or family, not as yet another tired sally in the battle against Mother Church or Mother Ireland, but as relating to a very real crisis in how wider communities are to function in an Ireland deeply implicated in global socio-economic relations.

\section{Progeneration}

To see how this might be the case it is worth examining briefly the distinction the social anthropologist Tim Ingold makes between 'genealogy' and 'relation'. In the genealogical model, individuals are seen as entering the lifeworld with a set of ready-made attributes which they have received from their predecessors. The essential parts which go to make up a person, his or her 'culture', are handed on, more-or-less fully formed. The popular image for this conception of personhood and community is that someone has something in their 'blood' or, more recently, 'in their genes. The metaphor indeed became commonplace in the last general elections in Ireland where certain independent TDs were described by media pundits as being in the Fianna Fáil 'gene pool'. The relational model, on the other hand, relates to the concept of 'progeneration' which Ingold defines as the, 'continual unfolding of an entire field of relationships within which different beings emerge with their particular forms, capacities and dispositions.5 That is to say, whereas the genealogical model is concerned with past histories of relationship, the unfolding development of a bundle of preset attributes in

5 Tim Ingold, The Perception of the Environment: Essays in Livelihood, Dwelling and Skill (London: Routledge, 2000), p. I42. 
a given space, the progenerative model is primarily concerned with current sets and fields of relationships for persons in a given lifeworld.

The genealogical model has obvious affinities with the notion of 'family' or indeed, muintir, in both a narrow nuclear and wider kinship definition of the notion. It is the model which clearly informed the 2004 Citizenship Referendum that introduced the notion of bloodline into definitions of Irish citizenship. It is also a model which is implicit in the blueprint for future economic development promoted by the social commentator David McWilliams. In his work The Generation Game, based on a TV series of the same name, he argues that Ireland's hopes lie with its diaspora, who are seen to have a more viable emotional and cultural commitment to the island's future than recent non-diasporic migrants to Ireland. ${ }^{6}$ In the genealogical model the descent line is separate from the life line and life and growth become the realisation of potentials that are already in place. So being Irish is to be a member of family which through immediate (domestic) or extended (diasporic) bloodline is endowed with a culture that is determined by essence rather than context. One consequence of the model is that cultural difference in Ireland is almost invariably construed as 'diversity'. That is to say, the notion of diversity, which is becoming something of a mantra of official pronouncements on multicultural Ireland, supposes that different groups possessed of different sets of ready-made attributes are juxtaposed in the shop window of contemporary Ireland and each group acting out their pre-defined cultural script contribute to the effervescent display of cultural diversity. So the invocation of diversity which is often seen as a way of countering nativist genealogical exclusiveness in fact tends to partake of the same logic but simply multiplies the examples of genealogical inheritances rather than challenges the basic logic.

In the narratives of Enright and Ó Treasaigh, the logic is questioned, albeit in less than explicit ways. Labhrás finds sympathy and self-understanding of a kind through his conversations with Darach, a refugee in time from the ravages of the Black Death in fourteenth-century Ireland. Darach comes not only from a different age but he is outside Labhrás's family circle. 
He is an antecedent not an ancestor. Similarly, Veronica's movement beyond the emotional stalemate of her life is not through the fraught communion with her immediate family but by way of the encounters she has with relative strangers in Ireland and in England. Stephen Dedalus's befriending of Leopold Bloom or Marcel's coming of age in the company of the invertis in La Recherche are earlier paradigms of a way of viewing personhood and community which is progenerative rather than genealogical. In other words, it is the sets of relationships which individuals and communities enter into at a given moment which engender change and the emergence of new forms, forms which are not obsessively pre-scripted by birthright. From this perspective, it is more appropriate to speak of positionality rather than diversity. Positionality, in effect, is to do with the sets of relationships obtaining at any moment between and within groups, relationships that are subject to an endless process of change, change which is the very stuff of the human life-line and which crucially includes the dimension of power. But even if the writers are suggesting that relationships need to be construed differently and that the cultural homeliness of the genealogical is no longer viable, where are these relationships going to take place and how will place itself affect them in a globalised world? How is the shared place that is the island of Ireland going to affect the forms that positionality will take as the society evolves through time?

\section{Altericide}

It is something of a philosophical and sociological truism (which does not make it any the less true) that our identity is defined through others. Just as difference is inconceivable without distinctness, so too identity is unimaginable without someone or something against which that identity 
is contrasted. ${ }^{7}$ Ireland as a country, for example, has notably defined itself through its relationship to Faith (religion), Fatherland (nationalism) and Fataí (land). An intense sensitivity to the view and perceptions of others is a notable feature of Irish public life and the lavish domestic coverage of the then Taoiseach Bertie Ahern's address to the United States Congress, as opposed to the general indifference of the United States media, showed how the good opinion of powerful others is an intrinsic component of Irish self-identity. Part of the difficulty in late modern Ireland is that the Others which defined the country, ethnic conflict (nationalism), a confessional state (religion) and an agricultural economy (land) are no longer dominant as ways of defining emerging Irish identities given that political, social and economic developments in the 1990 s and 2000 s spelled an end to Irish exceptionalism. ${ }^{8}$ One of the more stable elements of Irish intellectual life for three decades was the anchor of conflict so that where anyone stood on the National Question was an infallible guide to whether the Other should be eulogised or excoriated in print. The structural cues of attrition are no longer there and their absence makes, among other things, the future of Irish studies deeply problematic. But the changing status of otherness needs to be situated in a wider context to get a keener sense of the dilemmas faced by populations trying to make sense of where they stand in the present global moment.

Dominique Quessada has argued in Court traité d'altéricide that the most striking feature of the contemporary age is the prevalence of what he calls 'altéricide' which he defines as the 'liquidation systématique des modalités d'existence de la figure de l'Autre" ('systematic liquidation of the modes of existence of the figure of the Other'; [my translation]). Quessada traces a history for altericide which begins, he argues, with the Christian Incarnation. When a deity takes on a human form, there is a diminution in the radical otherness of the divinity. As Yahweh, the radically unknowable

7 François Julien, De l'universel, de l'uniforme, du commun et du dialogue entre les cultures (Paris: Fayard, 2008), p. 34.

8 Michael Cronin, 'Minding Ourselves: A New Face for Irish Studies', in The Field Day Review, 4 (2008), pp. 175-85.

Dominique Quessada, Court traité d'altéricide (Paris: Gallimard, 2007), p. 40. 
Other, becomes Christ, the mortal human, the gods not only mingle with mortals, God becomes mortal. Jesus as man becomes the subject of readily identifiable human narratives in the gospels. Following through to the present, Quessada sees the collapse of Soviet communism and the worldwide embrace of the market economy as a further evidence of the demise of the Other, as the alternative economic and geopolitical order of the Soviet bloc gives way to the hegemony of commodity capitalism. The very concept of globalisation itself with its notion of the 'global' as all-inclusive is symptomatic of the absence of an exteriority, of an outflanking of critique by larger categories of co-option. The death of the Other does not mean, however, that there are no longer any differences. On the contrary, there have never been so many. As Quessada intimates:

Si les différences peuvent proliférer, c'est parce que l'Autre n'est plus là pour leur faire barrage globalement: le concept métaphysique de l'Autre est ce qui contenait (au double sens d'englober et de retenir-empêcher-freiner) les différences, puisqu'il représentait la différence absolue face à laquelle les différences et microdifférences qui coexistent aujourd'hui n'avaient pas le moindre sens en elles-mêmes. ${ }^{10}$

(If differences can proliferate, it is because the Other is no longer there as an overall obstacle. The metaphysical concept of the Other is what contained (in the dual sense of encompassing and holding back-preventing-restraining) differences because it represented the absolute difference compared to which the differences and microdifferences which co-exist today did not have the slightest bit of meaning. [My translation.])

A direct consequence of the destruction of alterity is the multiplication of differences. It is not because the Other disappears that we are all condemned to sameness. It is possible to find the summary analysis of Quessada too glib and to point to American Special Forces in Iraq and Afghanistan as very much believing in a radical other that they have every intention of exterminating along with the persistence and deepening of global inequality as a reminder of the countless human Others who will not go away. However, it is nonetheless striking that the collapse of the public sphere in Ireland over the last decade is partly attributable to a native form of altericide. All 
the potential sources of political opposition in the form of unions, community groups and NGOs were brought into partnership arrangements with government and social partnership signaled the end of any serious opposition to official policy in the wider society. Similarly, the support of all four of the major parties for a Yes vote in the Lisbon referendum or the broad political front backing guarantees for the banking sector in October 2008 showed that any sense of radical otherness had succumbed to the managerial consensualism of a professionalized political class. That this phenomenon does not somehow announce the end of difference is borne out by the hugely successful pop sociology of Brendan McWilliams whose Pope's Children is replete with the endless differentiation of the pollster and marketeer: 'Yummy Mummies'; 'GI Janes'; 'Hibernian Cosmopolitans' and so on. ${ }^{11}$ The differences can be parsed endlessly because they no longer make any difference.

How then does altericide affect contemporary Irish perception of place and more specifically, how does globalisation inflect this perception in particular ways? A classic trope of Hegelian thinking is the master-slave dialectic, a recurrent figure in Hegelian descriptions of human interactions. Quessada evokes in the late modern world the existential figure of the Esclavemaître, 'un esclave qui est maître en même temps, tout en restant esclave, figure où maître et esclave sont littéralement indistincts, sans pour autant être confondus' ('a slave who is at the same time a master while remaining a slave, a figure in whom the distinctions of master and slave become literally indistinguishable, without the two states ever really being confused with one another'; [my translation]). ${ }^{12}$ This collapse of categories, the emergence of this seemingly contradictory, hybrid figure that is the 'Slavemaster' is deeply revealing of a profound uncertainty about Ireland as a place in the early twenty-first century. In 2007, Maureen Gaffney, the psychologist and media pundit, offered the Master's narrative in a warm encomium to the feel-good factor of Irish affluence:

II McWilliams, The Pope's Children: Ireland's New Elite (Dublin: Gill and Macmillan, 2005).

I2 Quessada, Court traité d'altéricide, p. I26. 
We seemed to have used our prosperity as an opportunity to enjoy stable family relationships, to develop our personal expressiveness and to show the world what we're good at. Given Ireland's economic, cultural and religious history - still in living memory - we have embraced prosperity, the good life and personal freedoms with unabashed relish, and we won't lightly let them go. ${ }^{13}$

The tone is not untypical of a slew of articles and public pronouncements in the boom years which presented Ireland as moving beyond the depressed divisiveness of the eighties to the irenic utopia of the twenty-first century. In contrast to the discourse of the Irish as Masters and Mistresses of all they Surveyed was an equally explicit narrative of dystopian malcontent. In this view, Irish society was one where citizens were the slaves of a brutalising and alienating system that led to the abandonment of values that had previously sustained it. The most notable exponent was the Ombudsman and Information Commissioner Emily O'Reilly in an address to the Ceifin conference in County Clare:

Many of us if we have any developed sensibility recoil at the vulgar festival that is much of modern Ireland, the rampant, unrestrained drunkenness, the brutal, random violence that infects the smallest of our townlands and villages, the incontinent use of foul language with no thought to place or company, the obscene parading of obscene wealth, the debasement of our civic life, the growing disdain of the wealthy towards the poor, the fracturing of our community life, the God like status given to celebrities all too often replaced somewhere down the line with a venomous desire to attack and destroy those who were on pedestals the week before, the creation of 'reality' TV, more destructive in its cynical filleting of the worth and wonder of the human soul than anything George Orwell could have imagined. ${ }^{14}$

O'Reilly and Gaffney co-exist in the same society and both would presumably see themselves as describing the same country. What is less important than adjudicating the respective merits of the Master and Slave narratives here is to suggest that public receptivity to both of these radically different interpretations of a particular time and place is in part to do with the presence of the Slavemaster as a dominant paradigm in a liberal-democratic

I3 Maureen Gaffney, 'What's the Craic?', in Irish Times Magazine, 25 August 2007.

I4 Emily O’Reilly, 'What has happened to us?', in The Irish Times, in November 2004. 
market economy. On the one hand, the citizen is consumer, the supreme master of choice, the active agent of destiny, the flattered subject of his or her multiplying desires. On the other, the citizen as producer is simply another object to be used, an eminently replaceable part of a process, a figure on a balance sheet, utterly subject to forces over which he or she has no control. ${ }^{15}$ Hence, the repeated feeling that the citizen is both master and slave depending on which role he or she happens to occupy at any given moment. The overall emergent effect is that of the Slavemaster, the shifting, uncertain inhabitant of contemporary Ireland whose view of the place is alternatively that of subject or object, in control or out of control, at home in the world or trying to cope with the world at home.

One factor that the citizen as Slavemaster has to contend with, and that we mentioned at the outset of this essay, is the incidence of time and how the accelerated time-space compression of globalisation impacts on appropriations and reappropriations of place. Tim Robinson, in his work Stones of Aran: Labyrinth, speaks of the daughter of one of his native informants on Inismore: 'I imagine his daughter is one of the smart young women I see driving into Cill Rónáin as if they were on a freeway to a shopping mall, slamming themselves through the island's spaces; she runs a chilly, hygienic, tourist-board-approved $\mathrm{B} \& \mathrm{~B}$, and hardly tolerates her father in the back kitchen. ${ }^{16}$ The elderly man and the young daughter may inhabit the same geographical space but their time zones are markedly different. The daughter's car slams through spaces collapsed by the acceleration of time. What Robinson attempts to do in his work is to restore the infinite complexity of those spaces, partly through his own decelerated practice of walking the fields of Inismore but partly also through the memories of older inhabitants, his informants, whose physical slowing down becomes a creative act of remembering. In a sense, Robinson's move is linked to the rehabilitation of dwelling as a creative or enabling way of engaging with places subject to the peripheralising dismissal of velocity.

I5 Christian Laval, L'Homme économique: essai sur les racines du néolibéralisme (Paris: Gallimard, 2007), p. I5. 


\section{Dwelling}

One of the most common icons of the global age is not surprisingly the globe itself. From the shots of the blue planet suspended over abyssal darkness courtesy of the Apollo space missions to the sketchy outline of earth on notices encouraging hotel customers to re-use their towels, the images of the planet are increasingly common in the contemporary imaginary. Seeing things from a distance is as much a matter of subjection as observation. Occupying a superior vantage point from which one can look down on a subject people or a conquered land is a staple of colonial travel narratives. ${ }^{17}$ There is a further dimension to the question of distance described by Tim Ingold where he draws a distinction between perceiving the environment as a 'sphere' or as a 'globe'. For centuries, the classic description of the heavens was of the earth as a sphere with lines running from the human observer to the cosmos above. As geocentric cosmology fell into discredit and heliocentric cosmology came into the ascendant, the image of the sphere gave way to that of the globe. If the sphere presupposed a world experienced and engaged with from within, the globe represented a world perceived from without. Thus, in Ingold's words, 'the movement from spherical to global imagery is also one in which "the world", as we are taught it exists, is drawn ever further from the matrix of our lived experience. ${ }^{18}$

In the movement towards the modern, a practical sensory engagement with the world underpinned by the spherical paradigm is supplanted by a regimen of detachment and control. As the images of the globe proliferate, often ironically to mobilise ecological awareness, the danger is that these images themselves distort our relationship to our physical and cultural environment by continually situating us at a distance, by abstracting and subtracting us from our local attachments and responsibilities. However, it is precisely such an ability which is often construed as a basic requirement

17 Mary Louise Pratt, Imperial Eyes: Travel Writing and Transculturation (London: Routledge, 1992), p. 216. 
for both national and, more latterly, global citizenship. It is the capacity to look beyond the immediate interests of the clan or village or ethnic grouping which creates the conditions for broader definitions of belonging at a national or indeed global level. Szersynski and Urry argue, for example, that 'banal globalism', the almost unnoticed symbols of globality that crowd our daily lives, might, 'be helping to create a sensibility conducive to the cosmopolitan rights and duties of being a 'global citizen', by generating a greater sense of both global diversity and global interconnectedness and belonging. ${ }^{19}$ The promise of such citizenship is an almost axiomatic contemporary defence of why anyone should bother, for example, with translation. When Pascale Casanova in her survey of the World Republic of Letters tries to synthesise those elements which have conditioned eligibility for citizenship of this Republic, translation is very much to the fore:

Dans l'univers littéraire, si l'espace des langues peut, lui aussi, être représenté selon une 'figuration florale', c'est-à-dire un système où les langues de la périphérie sont reliées au centre par les polyglottes et les traducteurs, alors on pourra mesurer la littérarité (la puissance, le prestige, le volume de capital linguistico-littéraire) d'une langue, non pas au nombre d'écrivains ou de lecteurs dans cette langue, mais au nombre de polyglottes littéraires (ou protagonistes de l'espace littéraire, éditeurs, intermédiaires cosmopolites, découvreurs cultivés ...) qui la pratiquent et au nombre de traducteurs littéraires - tant à l'exportation quà l'importation - qui font circuler les textes depuis ou vers cette langue littéraire. ${ }^{20}$

(In the world of literature, if languages can also be represented using a 'floral figure', that is to say a system where languages on the periphery are linked to the centre by polyglots and translators then it is possible to measure the literariness (the power, prestige, the volume of linguistico-literary capital) of a language, not by the number of writers and readers in a language, but by the number of literary polyglots (or main players in the literary arena, publishers, cosmopolitan intermediaries, well-educated talent spotters ...) who know it and by the number of literary translators - for export as well as for import - who cause texts to be translated into or out of this literary language. [My translation.]) the world from afar', in The British Journal of Sociology (2006), 57 (I), pp. I13-31, p. 122. 
The global standing of a literature depends on the efforts of those language learners and translators who can stand outside their own language and learn the other language for the purposes of reading and/or translation. But Szersynski and Urry ask the following questions: 'Is this abstraction from the local and particular fully compatible with dwelling in a locality? Could it be that the development of a more cosmopolitan, citizenly perception of place is at the expense of other modes of appreciating and caring for local environments and contexts? ${ }^{21}$

In opposition to the figure of the citizen we find the notion of the 'denizen' which has been propagated notably by the non-governmental organisation Common Ground where a denizen is deemed to be a person who dwells in a particular place and who can move through and knowingly inhabit that place. Therefore, Common Ground dedicates itself to encouraging the proliferation of vernacular, ideographic and connotative descriptions of local places which can take the form of place myths, stories, personal associations and celebrations of various kinds (www.commonground.org.uk). What Robinson's exploration of time and space on the Aran Islands points to is a form not so much of citizenship as of denizenship where 'caring for local places and contexts' is powerfully determined by an ability to shift time zones.

Implicit in the move is a relationship to land and place which is not wholly over-determined by an obsession with ownership. Finbarr Bradley and James Kennelly have noted that possession and care are not necessarily common bedfellows. They claim: 'In Ireland, ironically, a lack of concern with design and aesthetic quality tends to go hand in hand with a preoccupation with place. This affinity with place (it can hardly be called a sense of place) appears to have little to do with tending, cultivating or enhancing the material environment. ${ }^{22}$ In the light of Ireland's demonstrably poor world from afar', p. I23.

22 Finbarr Bradley and James Kennelly, Capitalising on Culture, Competing on Difference (Dublin: Blackhall Publishing, 2008), p. 49. 
environmental record, ${ }^{23}$ a seeming allegiance to place, repeatedly articulated in advertising campaigns around GAA championship competitions, is accompanied by a manifest inability or unwillingness to care for them. The hold of property over the national psyche as evidenced by the almost neurotic rehearsal of anxieties and fears during the post-boom downturn stands in vivid contrast to the general lack of urgency and engagement in addressing the systematic deterioration of place through climate change. In effect, what joins the concerns of Robinson to the ruminations of Enright's Veronica or Ó Treasaigh's Lahbrás is how to dwell properly in a place. How is it possible, for example, to dwell meaningfully in a country which has altered so dramatically in such a relatively short period of time?

\section{Time}

Quessada claims that one further consequence of the phenomenon of altericide is the triumph of the spatial over the temporal. That is to say that the preferred time of democracy is the present as both the past (different political regimes) and the future (everything from popular revolt to terrorism) both potentially threaten its legitimacy. He argues:

L'absence de temps, spécifique de la marche de la démocratie vers son accomplissement, fait que, pour être et avoir lieu, tout doit être et avoir lieu en même temps, c'est$\dot{a}$-dire dans le même espace. (p. Ioo; his emphasis)

(The absence of time, specific to the movement of democracy towards its realisation, means that, to be and to take place, everything must be and take place at the same time, that is to say, in the same space. [My translation.])

Arguments take time. It takes time to put forward a thesis sequentially, a counter-thesis and eventually some form of synthesis. In the sound bite

23 See for example Harry McGee and Tim O’Brien, 'Ireland far off emissions and waste targets, says EPA report', in The Irish Times, 9 October 2008. 
instantaneity of media-saturated democracies, the time of exposition is anathema. This is not to say that different viewpoints are not aired. They are, if only because there is a legislative obligation to do so. But to return to our earlier discussion of genealogy, what is offered is the spectacle of diversity rather than an engagement with positionality. In other words, different opinions on the budget are summarily aired, from the politicians to the trade unions to the employers' bodies. The opinions are simply juxtaposed as if they were all equally valid and everyone had the same ability to determine outcomes in the society which is patently not the case, as evidenced by strikingly uneven distributions of income in Irish society. ${ }^{24}$ So there is much diversity of a kind but rather less understanding. The time needed to tease out strands of power and influence is denied in favour of the spatialised collage of clips, individuals and groups rehearsing the prescripts of the representational ('on behalf of my party I would like to say'). In a sense, space is what happens to place when time tends towards zero. The less time a person has to dwell on what it means to live in a particular place, the more the place they inhabit becomes filled with the spatialised ubiquity of commodity advertising, ratings-driven media product and context-less information bites. Place becomes the site of the multiple surfaces of consumption, a tantalisingly fragmented space, detached from any longer-term sense of what it means to dwell in and be responsible for a particular place and how the place might be positioned relative to others. In this context, there is nothing more conservative than the repeated exhortations to abandon the past (Tara) and move rapidly into the future (the kinetic utopia of the $\mathrm{M}_{3}$ ). The truly radical scenario is to abandon the obsessive-compulsive rigidities of the short-term for the unsettling and innovative dwelling perspectives of the long-term.

In the short term in Ireland, of course, there is nothing more difficult than planning for the long term. The acceleration of technological change, the short-horizon perspective of a market-driven economy, the next-election

24 Brian Nolan and Bernard Maître, 'Economic Growth and Income Inequality: Setting the Context', in Tony Fahey, Helen Russell and Christopher Whelan (eds), Best of Times: The Social Impact of the Celtic Tiger (Dublin: IPA, 2007), pp. 27-42. 
perspective of representative democracy and the frantic multi-tasking that has become the daily lot of so many living and working on the island mean that a potentially fatal short-sightedness becomes the norm.

It is often said that what a people strive for is the greatest happiness of the greatest number but it is worth bearing in mind that the greatest number have not yet been born. Therefore, when we speak about the greatest good, what we really mean is the longest good. There is not much we can do to improve the quality of life of those who are already dead on this island but immeasurable good can be done to improve the quality of lives of those who will be born or come to live on the island. In order to give force to this notion of the longest good, it would be necessary to make the taking of long-term responsibility the most important political issue of our time. How might we do this and what are the short-term implications of long-term thinking?

Writing in The Irish Times, Frank Convery argued that 'a sustainable climate change strategy for Ireland must focus on the long term. ${ }^{25}$ The Stern Report and the reports from the UN Intergovernmental Panel on Climate Change have clearly spelt out the consequences of global warming and unchecked carbon emissions for water availability, sea levels, species survival, agriculture, ocean acidification, coral reefs, weather patterns and human settlement. The repeated conclusion is that humanity must begin to act now if it is to avoid catastrophic consequences in the long term. So farming practices, the types of crops produced, the way cities are planned and transport systems are organised, the kinds of goods and services that are produced and how they might be produced must change in the short term if there is to be a viable long-term future for humans and many other species on the planet. However, in the era of the instant opinion poll, the relentless style barometers of 'What's Hot' and 'What's Cold' and the instantaneous e-mail message, how are citizens to escape the tyranny of the moment?

25 Frank Convery, 'Climate Change must be factored into every aspect of our lives', in The Irish Times, 7 April 2007. 
In the language of the Tewa Indians of the American Southwest there is an expression, 'pin peyeh obe' which translates as 'look to the mountain'. When the Tewa elders use the phrase they mean that if we look at things as if from the top of a mountain we get a broader view, we see what lies ahead. ${ }^{26}$ We also, however, if we turn in another direction, see what lies behind. In other words, the long view is not only forwards but backwards. Just as our present was once someone's distant future, if we want to make sense of what might or ought to happen in the future we need to understand how we got here from our distant past. As our sense of time extends in both directions, being responsible for what might happen to future generations involves being equally responsible for learning appropriately from past generations. It is in this context that the downgrading of Old Irish as a full degree subject in the country's largest university and the threatened removal of the Chair of Old Irish had a significance which went far beyond the internal budgetary housekeeping of a particular educational institution. Ireland in comparative European terms was enormously fortunate at a very early period to have an extremely wide and varied body of writing in its vernacular language on a multitude of subjects from religion to jurisprudence. ${ }^{27}$ The study, analysis and transmission of the language and the associated culture and society makes a powerful contribution to how we understand the development of Irish writing, culture and society over an extended period of time. To think that far back is to develop the reflex of the long view which is not the subsidised indulgence of the scholar but a core survival value of any culture which wants to exist into the future.

The stereoscopic stories of contemporary Ireland, the Irish and Englishlanguage narratives of contemporary urban experience as they develop in the work of Enright and Ó Treasaigh point to the overwhelming need for the society to stand back, take stock and adopt the long view if the place that is Ireland is to have a sustainable future. What the novelists are suggesting Steward Brand, The Clock of the Long Now: Time and Responsibility (London: Phoenix, 2000), p. I 44.

27 Dáibhí Ó Cróinín (ed.), A New History of Ireland: Prehistoric and Early Ireland (Oxford: Oxford University Press, 2008). 
and what this essay has tried to articulate is that it is necessary to analyse how being turned 'inside out' by changing relationships of time and space affects in very profound ways the human capacity to dwell in any given place. But crises are famously moments of opportunity and it is perhaps time to call a different tune for the piper, a tune that is about place rather than property, about denizens rather than citizens and about the far-seeing rather than the short-sighted. 


\title{
2. The Global Irish Spirit
}

\author{
CATHERINE MAIGNANT
}

In the introduction to her book published in 2001 and entitled Irish Spirit, Patricia Monaghan writes: 'At a time when religion has been de-centred from the lives of Irish people, both individually and as a collective, the world looks to Ireland to save, if not civilisation, at least civilisation's spiritual component.' ${ }^{\prime 1}$ This chapter will seek to analyse this phenomenon, and to suggest interpretations based on the examination of some of its aspects. Patricia Monaghan's book provides a valuable starting point since it is a collection of testimonies by writers from Ireland and the Irish diaspora. All try to identify and define what 'the Irish spirit' means to them. The result is a kaleidoscope of interpretations and representations as the rich spiritual heritage of Ireland finds itself woven into the fabric of narratives inspired by individual experience and imagination. In most cases, it is a source of inspiration for the invention of personal forms of spirituality outside conventional religion. The spirit or spirits of Ireland are invoked through the sheer power of imagination and healing is expected to ensue.

This approach stands in sharp contrast with that of the Christian churches. Imposing the notion of an absolute truth defined by God was a way, for Christianity to rationalise religious feeling and to deny the validity of individual human perceptions. Because they were based on imagination and experience, personal representations of the sacred were indeed a threat to the institution, which feared loss of control: man's animal nature had to be curbed at all costs for order to be maintained among the faithful. Yet modern anthropologists and biologists have argued that imagination stands

I Patricia Monaghan (ed.), Irish Spirit (Dublin: Wolfhound Press, 20or), p. 8. Subsequent references will be to this edition with the abbreviation $I S$, followed by the page number. 
at the core of what it is to be human. In his seminal study of human nature, which he significantly entitled Le paradigme perdu: la nature humaine, Edgar Morin thus suggests that homo sapiens is also homo demens, and that it is precisely man's capacity to go beyond rationality which has allowed the extraordinary development of the human species. Imagination, Morin writes, plays a key role in defining human perceptions of reality. To him, the origin of religious feeling is to be found in the necessity for sapiens to be reconciled with death and must be understood as a response provided by the imagination to unbearable grief and unacceptable loss. Reality and illusion, objective truth and myth thus go hand in hand, as do absence and presence, or life and death, which can co-exist and be reconciled thanks to man's aptitude for both rationality and irrationality at the same time. ${ }^{2}$ Some biologists' recent conclusions may be understood as a confirmation of Morin's theory. Thus in their controversial book entitled Why God Won't Go Away, American brain specialists Andrew Newberg and Eugene D'Aquili argue that religious ecstasy produces visible alterations in some areas of the brain, which justify the feeling mystics have of union with the divine. ${ }^{3}$ This however is not to say that men necessarily imagine or invent their gods. According to the two scientists, this theory can be reconciled with religious belief so long as we admit that if a divine spirit exists, the only way it can make itself known to human beings is through the brain. In the same way as quantum physics demonstrates that the human brain builds its own reality, this theory establishes that there can be no representation of God or the divine outside the human brain.

To the Council for Interreligious Dialogue, such reconciliation between science and religion is a result of the 'tendency to interchange psychology

Edgar Morin, Le Paradigme perdu: la nature humaine (Paris: Seuil (Points Essais), 1973), pp. 107-26.

3 'Les faits donnent à penser que les origines les plus profondes de la religion se fondent sur l'expérience mystique, et que les religions persistent parce que les connexions du cerveau humain continuent de fournir aux croyants une gamme d'expériences unitaires qui sont souvent interprétées comme des assurances que Dieu existe.' Andrew Newberg, Eugene D’Aquili, Vince Rause, Pourquoi 'Dieu' ne disparaîtra pas (Paris: Sully, (200I) 2003), pp. 190-I. 
and spirituality, which developed from the end of the 1960 s. It is also to be connected with 'transpersonal psychology, strongly influenced by Eastern religions and by Jung', which 'offers a contemplative journey where science meets mysticism.' ${ }^{4}$ Pope John Paul II once complained that the 'overall and systematic calling into question of traditional moral doctrine' was linked to what he called 'certain anthropological and ethical presuppositions." What is clear is that the authority crisis which the major Christian churches have been confronted to in the western world in the past decades is connected to the reappraisal of man's humanity and hence his imagination and emotions. In this context, the success of the Irish spiritual tradition as a source of inspiration has been quite striking. In Irish Spirit, Patricia Monaghan argues that Ireland's spiritual heritage is so rich that our contemporaries can find within it their 'way forward into the future.'

Nowhere is this better exemplified than in the fact that Ireland appears to many as a promised land. Of these, the most controversial group is no doubt the neo-pagans. It is usually estimated that the number of pagans in Ireland now reaches a few thousand, most of these being adepts of druidism, shamanism or white magic. The most popular of these movements is actually witchcraft or wicca, as its followers usually call it. The two druids who unsuccessfully requested their community to be included in the first structured talks between the Irish state and various faith groups in the spring of 2007 were Irish. However, a striking proportion of these pagans are foreigners, Europeans for the most part. Dialogue Ireland, the Irish association whose aim is to promote awareness and understanding of New Religious Movements comments that indeed, 'Due to its Celtic origins', Ireland seems to be fast becoming 'the place to be for wiccans and pagans of all kinds.? English-born Bev Richardson, who runs an Irish school of witchcraft at Castle Pook in North Cork thus explains that after travelling

4 Pontifical Council for Interreligious Dialogue, Jesus Christ the Bearer of the Water of Life: A Christian Reflection on the New Age (http://www.vatican, 2003), p. I4. John Paul II, Veritatis Splendor (http://www.vatican.va/holy_father/john_paul_ii/ encyclicals/documents/hf_ip-ii_enc_o).

6 Monaghan $(I S)$, p. 335 .

7 http://www.esatclear.ie/ dialogueireland/. 
across the British Isles in a horse-drawn wagon from the latter I970s into the I990s, 'seeking out hidden places of power' and 'always looking to grow in the mystery,' he and his wife eventually settled in the West of Ireland in 1995. This was no accident. In the eyes of post-modern gurus, Ireland still corresponds to the image conveyed by late nineteenth- and early twentieth-century nationalists: to them, it is by excellence the land of myth and magic, where one can easily have access to spirits of the earth that have disappeared elsewhere.

Very few, however, actually fulfil their dream and settle in the Promised Land that Ireland has become. The hundreds of thousands of other pagans across the world (particularly in the United States) have no option but to invent an artificial connection with the Promised Land. This they do through the means of the internet. Bev Richardson created the very first Irish pagan website (Pagan Ireland) in 1995 and there are a number of other Irish-based websites, but most of the Celtic Irish pagan websites are based elsewhere, most of them in the United States. Some of these are run by second- or third-generation Irish emigrants, like Michael Ragan who founded the organisation of the Temple of Danann in 1979, following a trip to his 'maternal parents' homeland'.

The internet is a place where rationality and irrationality meet. It is consequently no wonder that new religiosities should have felt at home there since the internet embodies our age of globalised information, communication and culture. The internet gave New Religious Movements the possibility to exist and proliferate as technical progress gave them access to new mystical paths beyond the screen. The Irish-based Fellowship of Isis, whose adepts venerate the great cosmic mother in all her shapes, including Brigit, is an excellent illustration of this phenomenon. It started in a small way in Ireland ${ }^{9}$ with forty-four people. Thanks to the internet, the movement gathered momentum in the r990s and it now claims roughly 25,000 members living in ninety-eight different countries. In this new world, the traditional oppositions between reason and faith or science

8 http://www.paganireland.com/.

9 At Clonegal Castle (Huntingdon), near Enniscorthy, County Wexford. 
and religion seem to have become meaningless. To Jacques Derrida, the current 'ré-enchantement du monde' is in fact the consequence of scientific and technical developments. However, he argues, the new forms of religiosity relying on computer systems have induced a 'radical destruction' of religion in its traditional understanding. ${ }^{10}$ Despite the claim that contemporary religiosities are inspired by ancient philosophies, whatever their origins, despite the seeming parallel between these religiosities and past Gnosticism and Hermeticism, they must be understood as complete innovations, both in their contents and practices. They are the product of the late modern age whose fundamental characteristics, contradictions and ambitions they share.

It may seem paradoxical that new religiosities should owe their success, their survival or even their existence to the internet, given that the web theoretically embodies values that are opposed to those preached by the adepts of New Religious Movements. Indeed the latter reject all founding stones of the ideology of progress. The realities of the dehumanised, polluted, all economic contemporary world are also abhorrent to them. The paradox however is no more than apparent for it can be argued that the internet provides an ideal medium for those who are engaged in a quest for a transparent universe where a new disembodied, dislocated or rootless human species may be united in a universal soul. The web is a virtual space where science and religion meet, and where the cyber-faithful are given access to a new identity and a new form of social connection that are both entirely founded on the possibility to communicate and be informed. It seems in fact that the internet is perfectly adapted to the needs of neoarchaic spiritualities from a technical point of view, and that it echoes their ethical ideals. If adepts of cyber-religiosities openly reject modern ideals, they seem in reality to accept most late modern values, including those of the consumer society. Patricia Monaghan notes that 'spirituality has become - along with cream liqueur and traditional music - one of [Ireland's] signature exports. ${ }^{11}$

Io Jacques Derrida, Foi et raison (Paris: Seuil, I996), p. 46.

II Monaghan $(I S)$, p. 2 I3. 
Among other services that are advertised on the internet in the name of the Irish spirit, Celtic pilgrimages deserve special mention. Indeed they combine tourism and spirituality, and they are meant to appeal to people who look to Ireland as a Promised Land. Those who let themselves be convinced to go on an Irish pilgrimage appear to come from very wide-ranging horizons. They are natives of various countries across the Western world. Some have different protestant backgrounds, some used to be Catholic; others claim they still are Catholic to some extent; some even are ecclesiastics or religious, while others still are agnostic or vaguely neo-pagan. Beyond belief in ecumenism, what these pilgrims have in common is their quest for a 'total existential experience' which will transform their lives and result in what they see as 'the growth of the inner self.' ${ }^{12}$

This inner journey is echoed by the outer journey, for 'the primary focus of a pilgrimage is the interior growth resulting from an exterior journey. ${ }^{313}$ These two complementary journeys can finally be understood as a metaphor of the journey life as a whole is thought to be. 'The ultimate pilgrimage is the spiritual journey we all experience from birth through life to death', American Revd Bruce Reed Pullen writes. Indeed, in recent years, voices have been raised throughout the Western World to reinterpret and reinvent pilgrimage as understood by early medieval peregrini, in an attempt to revivify Christianity and adapt it to the needs of our present day and age. Dr Pullen has thus enthusiastically called for a reappraisal of Celtic Christianity and set it as a model for the future. 'Although the Celtic way became "the way not taken", the way of Ninian, Columba and Aidan is still with us', he wrote in 1999. 'The roots of Celtic Christianity are the base from which springs the way yet to be taken. ${ }^{14}$ Celtic pilgrimages, as they are now called, are central to the process of spiritual rejuvenation which aims at healing pilgrims by making them experience the wholeness

I2 Cintra Pemberton, Soulfaring - Celtic Pilgrimage Then and Now (Harrisburg: Morehouse Publishing, 1999), p. 9. Subsequent references will be to this edition with the abbreviation $S$, followed by the page number.

I3 Pemberton $(S)$, p. 9.

I4 Bruce Pullen, Discovering Celtic Christianity (New London: Twenty-Third Publications, 1999), p. I28. 
of the divine. This alchemy, they believe, can only be wrought in very special sacred places, to be found in Celtic lands, and in Ireland particularly, which is saturated with holy memories subsumed in liminal places that are the threshold between heaven and earth. Visiting such places in given circumstances allows one to experience eternity.

Celtic pilgrimages, which have been defined as 'quest [s] for meaning, ${ }^{15}$ are very different from the traditional pilgrimages organised by the Catholic Church. To start with, they are more about healing than about penance. It can also be argued that they are rooted in the desire or need to recover the lost sense of mysticism. That they suggest an answer to those who have lost faith in the institution is no less clear. Sister Cintra Pemberton, ${ }^{16}$ another American expert in Celtic pilgrimages, actually thinks that:

[...] contemporary pilgrimage reflects today's spirituality, which tends to be more holistic. Today's holistic pilgrimage [...] may not be church-related at all but rather related to a widespread disillusionment with the institutional Church. Pilgrimage today is likely to be undertaken as a way of assuaging spiritual hunger - a hunger that for many people may no longer be fed by the Church. ${ }^{17}$

The quest which is thus undertaken must lead the pilgrim to reflect on his own life and take the risk of being transformed as a result of the process. According to Mary Condren, the director of the Institute for Feminism and Religion in Ireland, this goes against the sense of false security that can be provided by 'religious pilgrimages, where everything is predictable, ritualised and comfortable.' 'Pilgrimages or exiles that do not make us think', she goes on to say, 'far from being challenging, can lock us into our old versions of truth [...]. They can feed our addictions to answers, blocking out the very questions that might need to be asked. ${ }^{18}$

I6 Cintra Pemberton is a member of the Episcopal Order of St Helena. The order of St Helena is a religious order for lay and religious women in the Episcopal Church. http://www.osh.org.

I7 Pemberton $(S)$, p. 46.

I8 Mary Condren, 'The Uncreated Conscience of our Race', in Padraigin Clancy (ed.), Celtic Threads (Dublin: Veritas, I999), pp. 9-10. 
Questioning established truths and rituals whilst seeking new ways to the sacred naturally involves using the power of imagination, which, to experts in Celtic pilgrimages is a key to success. Dara Molloy observes: 'It means personal empowerment using our own ability to create meaningful worship rather than relying on others to do it for us. It means being able to use material from within a tradition without being limited or constrained by it. ${ }^{19}$ The tradition invoked is basically Christian, though it is critical of canonical Roman Catholicism, but it also derives much of its inspiration from what remains of pre-Christian culture. To Dara Molloy, the preChristian spiritual tradition is 'the Irish Old Testament', and it 'spans five thousand years', thus including the traces of the pre-Celtic, Neolithic age. He distinguishes that period from the early Christian history of Ireland, starting, he says, with St Patrick, reaching its climax between the seventh and the tenth centuries, before being eventually superseded by the Roman tradition from the twelfth century onwards. ${ }^{20}$ All adepts of Celtic Christianity stress the continuity between pagan and early Christian times and they seek to recover what they believe to have been the extraordinary mystical intensity deriving from the merging of different spiritual traditions in Celtic lands.

Following the model of early monks, the most devout are prepared to leave everything behind when a spiritual experience very much of a peregrinate-type results in their finding their 'place of resurrection', where they settle for good. Dara Molloy, who used to be a Catholic priest, explains that he was 'spellbound' when he first visited Aran in 1982. 'It put me in touch with a part of myself that I had not known existed', he writes. 'It brought that part of me to life, and it is that part of me that now forms the centre of my life. ${ }^{21} \mathrm{He}$ came back three years later and started to live as a Celtic monk. Threads, p. I05.

20 Molloy, p. I05. 
To Esther De Waal, the rediscovery of the Celtic World itself is a journey, 'a peregrinatio, seeking, quest, adventure, wandering, exile - it is ultimately a journey $[. .$.$] to find the place of my resurrection, the resur-$ rected self, the self that I might hope to be, to become, the true self in Christ'. Such an understanding of the Celtic pilgrimage allows anyone to feel concerned. One no longer has to renounce everything, but simply to wish for a rebirth, which can fairly easily be obtained as a result of a short trip to a Celtic sacred place. 'This journey', Esther De Waal concludes, 'is only possible because I am finding my roots. ${ }^{22}$ This modern interpretation of the peregrinatio is interesting in that it involves a journey through both space and time. Indeed, it both necessitates 'a sense of connectedness with the earth itself ${ }^{23}$ in some privileged locations and the aptitude to connect with the so-called Celtic past. 'To find my roots takes me back to the part of my self that is more ancient than I am', Esther de Waal explains. ${ }^{24}$ As a consequence, places resounding with memories of ancient cults are channels through which today's pilgrims may hope to be resurrected and filled with spiritual energy even if they have no intention of settling there on a permanent basis.

One central difficulty however, when it comes to creating one's own spiritual self and devise one's own rituals on such a basis, is that the longedfor connection is more imagined than real. Indeed the concept of tradition, which is used to legitimise the contemporary Celtic practices, is derived from the Latin tradere, which means to hand down; and it is quite striking that this form of spirituality has not been handed down to its adepts. In fact, they have even partly rejected the religious tradition of their fathers. Talking about post-Christian France, sociologist Danièle Hervieu-Léger talks of the 'transmission crisis ${ }^{25}$ which is inherent in the current fragmentation of religious identities, and the model she defines certainly applies to Celtic Christians. True, religious tradition has always been adapted to

Esther De Waal, The Celtic Way of Prayer (London, Sydney, Auckland: Hodder \& Stoughton, 1996), p. I.

23 De Waal, The Celtic Way of Prayer, p. 2 I.

24 De Waal, The Celtic Way of Prayer, p. 21.

25

Danièle Hervieu-Léger, Le Pèlerin et le converti (Paris: Flammarion, I999), p. 6I. 
suit the needs of each new generation, but innovation and remembrance were never disjoined, and the past served as a fixed point of reference. At the same time, collective memory ensured the survival of a community's religion by the continuity of transmission. Up to recent times, religion and memory were thus intimately connected. In the present case, not only is the adaptation process stretched to the extreme, but the past that is referred to is so distant that little is known about it and there is no living memory of it. And yet, it is called upon to help the person in need of healing make sense of the present and build the future. The process at play is the reinvention of a religious continuity and of a collective memory based on identification with a largely reinterpreted or even reconstructed tradition. The legitimising function of the past necessarily makes it a central preoccupation, hence the stress that is laid on the 'Celtic heritage'.

The nature of this heritage as it is described by believers is quite significant also of the deep changes that have taken place. What is seen as particularly important is landscape and stories, historical events and their location, and the endless succession of past generations that can be viewed as the true bond between the Celtic past and the present. These dead people are the missing link, the proof that the tradition has been handed down after all. 'Our history has been written in the landscape', Dara Molloy explains, 'when we worship outdoors, we not only see the hand and experience the presence of the Divine in nature, but we also have an opportunity to get directly in touch with our ancestors who lived on the land before us. $\mathrm{He}$ concludes:

Previous generations have marked out for us the sacred hills and wells, the pilgrim paths and holy islands. They have left on the landscape the dolmens, standing stones, ring forts, round towers, churches and monasteries that remind us of our spiritual heritage;

We can connect also with the suffering and tragedies of our ancestors, the famine graves $[. .$.$] the Mass rocks in remote places, the locations of drownings, burnings,$ hangings, murders and accidents.

Connecting with our ancestors through their marks on the landscape is an act of worship, as was the recording in the Bible of the story of the Hebrews; remem- 
bering our history and reflecting on it in the light of God's love is a healthy spiritual exercise. $^{26}$

Stories are powerful guides in this journey to the past and Celtic pilgrimages involve a lot of storytelling. Their organisers always insist that the groups 'will be joined by Celtic specialists, mythologists [...] and storytellers to share experiences and offer guidance $[. ..] .{ }^{27}$ On day five of a walking pilgrimage of Southwest Ireland, the organiser thus announces: 'We gather in the early evening and are honoured to be in the presence of one of the Beara's few seanchai - sacred storyteller. We enter Ireland's landscape of story as we listen to the ancient legends of Ireland and the Beara. ${ }^{28}$

The process is also interactive and the pilgrims are encouraged to tell their own life stories. Dara Molloy includes in his 'suggestions for a Mass based on the Celtic heritage' a storytelling ritual which is understood as follows: 'People are invited to tell a story. Sources to draw from can include the Bible, the Irish tradition, other wisdom traditions and personal stories. ${ }^{29}$ In the same way Sapira.com, advertising a Celtic pilgrimage to be held from Newgrange to Glendalough in May 2005, summarises the goal to be reached in this way: 'This is a journey with the purpose of discovering and connecting our own stories with the tradition as seen through the lens of the magnificent landscape and the luring legends. ${ }^{30}$ Role-playing may be used to that purpose as was for instance the case in the conference entitled 'Brigid: Prophetess, Earthwoman and Peacemaker', which was organized in Kildare in the 1990s. On that occasion, 'Some Brigidine legends and myths were dramatised and retold as parables [...]. ${ }^{31}$ Kate Fitzpatrick, who has been trained in the art of using mythology, drama, gestalt therapy

26 Molloy, 'Creative Worship in the Celtic Tradition', in Clancy (ed.), Celtic Threads, pp. 108-9.

27 http://www.illuminatedjourneys.com/take_a_pilgrimage.htm.

28 http://www.lifepilgrimage.com/walking/where.html.

29 Molloy, 'Creative Worship in the Celtic Tradition', in Clancy (ed.), Celtic Threads, p. III.

30 http://www.sapira.com/ireland_landscapes.php.

3I Mary Minehan, 'Kildare Today: Continuing the Brigidine Tradition', in Clancy (ed.), Celtic Threads, p. 167. 
and ritual to create experiential healing journeys, ${ }^{32}$ explains that type of experience as follows: 'When we work with myth in the healing process, we are re-weaving the original myths. We are restoring our soul's need for myth and our need to be in balance with nature. With the healing symbols that we create in myth-making, we are dreaming the future into manifest existence. ${ }^{33}$ The past, present and future thus merge into an eternal present through the power of imagination. Myth supersedes reason and muthos ousts logos out of the believers' spiritual selves. Individuals can then enjoy a glimpse of eternity. Dolores Whelan puts it this way:

The world of myth allows us to soften the edge of our perception, to loosen the rigidity of boundaries that separate the material from the non-material. It allows us to develop our imagination, to see with the soft focus of inner eyes, to sense images that are gossamer thin and would not survive in the harsh world of logos. ${ }^{34}$

Only in places supposedly 'saturated with the presence of ancient Celts [or] historical saints ${ }^{35}$ and anchored in myth is such a unique experience possible. What sociologist Michel Maffesoli calls 'tribal myths ${ }^{36}$ allow one to weave time into place, a process which is intrinsic to the formation of alternative spiritualities in the post-modern world. 'People of faith have a heightened sense of place', Revd Pullen claims. 'Some believe, as did Ciaran', he adds, 'that a site could be a "thin place" with less of a barrier there between heaven and earth. ${ }^{37}$ Sister Cintra Pemberton agrees that 'certain places $[. .$.$] have a peculiar quality, a liminality, where encoun-$ ter with the Holy is immediate and overwhelming. ${ }^{38}$ According to her,

32 Minehan, 'Kildare Today: Continuing the Brigidine Tradition', p. 196.

33 Kate Fitzpatrick, 'Celtic Myth in Healing Process - A Journey (with Cú Chulainn) to the Warrior of Heart', in Clancy (ed.), Celtic Threads, p. 81.

34 Dolores Whelan, 'Celtic Spirituality: a Holy Embrace of Spirit and Nature', in Clancy (ed.), Celtic Threads, p. 20.

35 http://www.sapira.com/ireland_lanscapes.php.

36 Michel Maffesoli, Notes sur la postmodernité - Le lieu fait lien (Paris: Le Félin, 2003), p. 35 .

37 Pullen, Discovering Celtic Christianity, p. 90.

38 Pemberton $(S)$, p. I3. 
'unknown ancient sites' are even more attractive in many ways than major pilgrimage locations since 'they retain their original rich aura of sanctity and historical authenticity. ${ }^{39}$

In the eyes of would-be pilgrims, thin places may in fact be found anywhere a form of boundary can be identified, and visits to these locations are no doubt justified. One such threshold is that which separates this world and the next. Thus has pilgrimage to Skellig Michael been interpreted as 'a rehearsal for the soul's journey to eternity, ${ }^{40}$ both because St Michael is believed to guide the souls of the dead to the otherworld and because folklore tradition connects this island with Tech Duinn, another name for Tír na nÓg. As a symbolic threshold between the Christian and the preChristian cultures relating to death and eternal life, it is a favourite spot for Celtic pilgrims. In this case the eternal present even seeks to encroach on the eternal future of death, which is thus partly conquered by the living. It naturally also symbolises the sought-after birth to a new life.

This rebirth is the result of a collective as much as individual experience. One could then argue that the necessity to find 'like-minded people' is in fact to be understood as one aspect of the 'hunger to belong ${ }^{31}$ experienced by people who create their own set of beliefs on a pick and choose freelance basis. This need may very well point at the limit of the self-validation of belief when belief is dissociated from the sense of belonging. As in the model defined by Danièle Hervieu-Léger, self-validated beliefs become mutually validated beliefs through communion with others. ${ }^{42}$ In the case of Celtic pilgrimages, this communion is based on personal testimonies and the exchange of personal experiences, which gives story-telling and the telling of one's own story a new meaning. Indeed, 'narrative self-construction' becomes the condition allowing the formation of the collective religious

39 Pemberton $(S)$, p. 49. Bantam Press, 1998).

Seán O'Duinn, 'The Cult of the Dead in Early Irish (Celtic) Spirituality', in Clancy (ed.), Celtic Threads, pp. 68-9.

I The title of John O'Donoghue's book is significant in that respect: Eternal Echoes Exploring our Hunger to Belong (London, New York, Toronto, Sydney and Auckland:

42 Hervieu-Léger, Le Pèlerin et le converti, pp. I80-2. 
identity embodied in the group with which the individual identifies. ${ }^{43}$ But it seems that such forms of spirituality largely rest on the fact that the group symbolically shares a territory for the duration of the mystical union. The site of worship is the only 'common denominator' between the worshippers, and this place becomes what Rilke called Raum des Rühmung, the location where the celebration is held. In this understanding, the celebration place binds people together in an emotional communion. It actually creates the condition for a religious experience to be shared by creating the bonds that it was the original etymological function of religion to establish.

The concept of 'presenteism' has been used to refer to this aspect of the late modern ethos, ${ }^{44}$ which implies the experience and sharing with others of a glimpse of an eternal present subsumed in a given place. Life has become a succession of brief moments of eternity that must be enjoyed as much as possible. This hedonistic ideal is sought within various groups with which the individual chooses to connect and identify for a short period during which he plays an appropriate role. Identities are then fragmented into a series of loose identifications. Nowhere is this phenomenon better exemplified than in Celtic pilgrimages. In Pullen's view: 'The third millennium will see a return to those localized provisional communities which flourished in the first one. ${ }^{35}$ Danièle Hervieu-Léger, for her part, has reached the conclusion that pilgrim religiosity, which has become so fashionable in the Western world under different guises, can be understood as a metaphor of 'an expanding form of religious sociability based on mobility and temporary associations. ${ }^{36}$

Many of those who connect with the land of Ireland through the channel of the internet share with Celtic pilgrims both the hunger to belong and a specific sense of place. Indeed, reinventing the Promised Land and inviting people to meet in virtual Ireland is on the agenda of some neo-pagan webmasters. A significant example of this type of practice is provided by

44 Maffesoli, Notes sur la postmodernité, p. 37.

45 Pullen, Discovering Celtic Christianity, p. 45.

46 Hervieu-Léger, Le Pèlerin et le converti, p. 98. 
an American-based Celtic cyber-community called The Summerlands. Its website includes a very precise map of a marvellous island, which reminds us of Thomas More's Utopia or of the magic islands of the Irish Celts' pagan otherworld. Visitors are invited to meet in various meeting places at appointed times in a very friendly spirit. You can have a pint of virtual Guinness at the virtual pub, you can click on the virtual fireplace to sit by the virtual fire; you can read all sorts of books about Celtic Ireland at the public library and even learn the Irish language. The invention of the virtual territory of the neo-tribe is an indication of the importance of place in contemporary religious movements. The only common denominator between the members of loosely connected 'post-modern tribes', as sociologist Michel Maffesoli calls them, may indeed very well be their perception of a 'sense of place', which makes them adopt a territory as part of their cultural and religious identity. The possibility of social connection relies on the existence of a common territory, he says. The territory thus binds together the members of a community. ${ }^{47}$ Virtual Ireland clearly plays that role for Celtic neo-pagans on the internet.

Connecting with the land one way or another appears to lead some to a rebirth, understood as a birth to their real hidden identities. Adepts have the feeling they are coming home to their true land, whether the homeland of their ancestors, or their adopted homeland. This induces a rejuvenation of the self that somehow makes the future possible. 'When I first set foot on Irish soil', American born Michael Ragan says, 'my only intention was to relax, enjoy and then get back refreshed to a demanding job.' Ten days later, he continues, 'as I climbed aboard the jet at Dublin airport, I realized that something significant had happened, I just wasn't sure what it was. He proceeds to explain that he had had a sort of spiritual revelation which was to determine his whole life. New York's agnostic columnist Pete Hamill admits to having had a similar experience on his first trip to Ireland. It all happened when he first glimpsed Ireland from the plane: 'My scalp tingled', he recalls. 
My skin pebbled. I felt a sensation of something invisible rising towards me, like atomic particles. A kind of fine dust made up a billion of scrambled messages directed at me from the green silent land. Transcending centuries. Or millennia. Rising from beyond the knowable world and its wretched histories, to speak to me.

Come, they seemed to whisper.

Come home, we've been waiting for you. ${ }^{48}$

If the members of the Irish diaspora may rightly feature as the chosen people, because their ancestors came from the Promised Land, Irish neopagan websites suggest that one can also choose the territory of one's rebirth and adopt it as homeland. For instance, one of the most important neodruidic international movements, Ár nDraíocht Féin (or ADF), raises the issue of nationality in a web page entitled 'Frequently Asked Questions about Neopagan Druidism. The first six questions in the list are about the nature of neo-druidism and the legitimacy of druids. Question number seven however reads: 'What if I am not Irish?' A reassuring but puzzling answer follows: 'You don't have to be. Despite ADF's Irish name and their use of the Celtic term for clergy ('druids'), their members come from a wide variety of ancestries, including European, Asian, Native American and African. ${ }^{49}$

The homeland seems in fact to be understood both as the land where one's ancestors are buried and the mother land that will bring one to a new life. One contributor to Patricia Monaghan's collection, Elizabeth Cunningham, thus writes: 'I am not Irish. That is why I am writing this essay - to explain how someone who is not Irish can be captivated by the Irish spirit.' To her, or rather the main character of the novel she wrote, a certain Maeve, 'everyone is a little bit Irish. ${ }^{50}$ Ireland can in fact be anyone's place of origin. Because of the traces of matriarchal culture that survived the Celtic conquest, Ireland can be interpreted as the epitome of mother earth, the symbol of life and regeneration. Interestingly, Elizabeth Cunningham doesn't seem to have good memories of her one and only visit to Ireland as

48 Pete Hamill, 'The Long Circle Home', in Monaghan (IS), p. I8.

49 http://www.adf.org/.

so Elizabeth Cunningham, 'A Celtic Mary Magdalen?', in Monaghan (IS), pp. 97-8. 
a teenager. The land that is meaningful to her therefore is not real Ireland, but the imagined Ireland to which her spiritual quest has led her. Yet this does not mean that she venerates ancient Irish gods or goddesses: in fact, she calls herself 'an ordained interfaith ${ }^{51}$ minister, priestess and counsellor who celebrates the Celtic Wheel of the Year. ${ }^{52}$ The Celtic affiliation is nothing more to her than the most relevant metaphor for her veneration of a universal mother. In the same way, the members of ADF 'honor Celtic, Germanic, Lithuanian, Polish, Greek and other Indo-European deities, ancestors and nature spirits'. Anyone 'interested in any of the old Indo-European cultures and its metaphysics, arts and customs' is welcome in ADF since, its archdruid claims, 'in general, neopagan druids have no time or sympathy for racist nonsense or cultural bigotry. ${ }^{53}$

In her article entitled 'We are all natives of somewhere' Barbara Flaherty, ${ }^{54}$ who has never been to Ireland even though she was born to an Irish-American couple, implicitly insists on the necessity to globalise spiritualities. She tells her readers that one day she was taking part in the ceremony of the Pipe of White Buffalo Calf Woman of the Lakota Nation in Alaska, she invited her Irish ancestors to the Pipe. 'I have had many spiritual teachers from different cultures', she writes: 'I am related to their lineages by teachings. I also have the spiritual ancestors of my faith who I feel guide me like Francis of Assisi. But now is not the time to name them. I am to name my own blood lineage and claim its history, challenges and its wisdom. ${ }^{35}$ The Irish spiritual tradition, or rather all Irish spiritual traditions from the earliest times, are thus called to contribute to the creation of a sort of global spirituality embracing all traditions of the world - yet channelled by the individual.

\footnotetext{
5I My emphasis.

52 Cunningham, in Monaghan (IS), p. 97.

53 http://www.adf.org/.

54 Barbara Flaherty is the founder of The Fourth order of Francis and Clare, 'an interfaith intertribal order of madmen, troubadours, fools and mystics'. Barbara Flaherty, 'We are All Natives of Somewhere', in Monaghan (IS), p. 60. 
Bev Richardson confirms the importance of personal experience when he writes that when he was contacted to contribute to an online discussion, the only relevant thing he could possibly say was 'an honest reiteration' of his 'personal experience of the magic of the living godhead in all its many forms' and his 'own feelings with regard to the spiritual journey that [had] thus far informed [him]. ${ }^{.56}$ The personal myth is written down to be transmitted to the world as a witness's testimony. In all cases, private experience matters much more than any dogma. Through the channel of the internet, or through books such as that edited by Patricia Monaghan, the personal myth is integrated into an age-old universal myth. This gives the individual a privileged access to the personal spiritual path which will allow him to find his place in the cosmos, as part of what Bev Richardson calls 'the planetary Being'; and he adds:

Surely, after 2000 years of organized religion we have reached the point we can collectively say 'enough is enough' and each of us individually reach out without fear into the waiting arms of the loving mother that is our earth-being. And the gentleteaching father that is the fertilising fire to the collective genius that is the living godhead of earth-based spirituality. ${ }^{57}$

According to theologian André Beauchamp, this is an important characteristic of the late modern age. Testimonies, he says, matter more than anything else; sincerity supersedes truth, and appearances have become more important than knowledge. ${ }^{58}$ The theorists of the transpersonal movement, who initiated this spiritual approach, disagree. To them myth is a metaphor. According to Jean Bolen, for instance, 'It's the metaphor that's truly empowering for people. It allows us to see our ordinary lives from different perspectives, to get an intuitive sense of who we are and what is important to us [...]. Myths are the bridge to the collective unconscious' at planetary level. ${ }^{59}$

56 http://www.paganireland.com/pi/confer.html.

57 http://www.paganireland.com/pi/confer.html.

58 André Beauchamp, La foi à l'heure d'internet (Quebec: Fides, 2001), p. I8.

59 Jean Shinoda Bolen, quoted by Drury Neville in Exploring the Labyrinth (Making Sense of the New Spirituality) (New York: Continuum, 2000), p. 57. 
The earth and the cosmos have consequently become the only relevant spatial references to adepts of new globalised spiritualities. The veneration of the planet as Mother Earth has even become a central component of these religiosities. On coming back from a Celtic pilgrimage to Ireland an enthusiastic Scotsman called Alastair McIntosh published an article in which he explained how much the Irish spiritual heritage had to offer in that respect. He wrote that even though he had worked in the past for the ecumenical Iona Community and drew deeply on Christian roots, he also believed in 'interfaith sharing and not just stolid dialogue' and in 'the femininity of God ... (I mean I want her as lover or not at all ... to hell with this "jealous father" heavy trip).' When he went off to Ireland he was looking for a true experience of the sacred, guided as he felt by

the Queen of the Faeries, known otherwise as the GCM or, throughout all Ireland - the BVM - GCM? BVM? - The Great Cosmic Mother, Blessed Virgin Mary 'Mother of God, Queen of Heaven!' It's such fun when you overcome inhibitions and really get into the Goddess right to the depths of her Christian and Pagan roots combined.

And he was not disappointed, because his trip to Ireland helped him recover a sense of what he was yearning for: a pagan Christianity. ${ }^{60}$ Brigit also appeals to many foreigners for the same reason. One contributor to Patricia Monaghan's collection, Aline O'Brien, an American witch who describes herself as a 'Priestess of the Reclaiming Tradition', venerates Brigit. In her article entitled 'Bridey in Cyberspace', she explains that she and her cell sisters - who, she says, are witches, pagans and Christians - are committed to maintaining throughout the world the sacred flame of Brigit, the goddess and the saint. They see Brigit as 'She Who Gives Energy' and they claim that by keeping Brigit's fire alive, they contribute to generating energy for this world and the otherworld. ${ }^{61}$ Three hundred flame-keepers in the world, she says, also light a candle to Brigit on her feast day every year from twelve

60 Alastair McIntosh, 'Over the Rainbow - An Irish Pilgrimage' http://www.alastairmcintosh.com/articles/r994_over_the_rainbow.htm.

6I M. Macha Nightmare (Aline O'Brien's name as a witch), 'Bridey in Cyberspace', in Monaghan (IS), pp. 292-3. 
different countries (Australia, Brazil, Canada, Finland, Greece, Ireland, the Netherlands, New Zealand, South Africa, Spain, the United Kingdom and the United States). 'We honour our heritage', Aline O'Brien concludes, 'as we take it into the age of the internet [...]. We reconstruct the ways of our ancestors in our high-tech, multicultural, post-modern world. We carry Brigit's light of consciousness through the darkness and into the future. ${ }^{62}$ To Mary Condren, the founder of the Institute for feminism and Religion in Dublin, Brigit is 'the Female Spirit of Old Europe personified. ${ }^{63}$ She is also the 'soulsmith for the new millennium' thanks to her power of regeneration. As for musician and songwriter Barbara Callan, she believed Brigit was 'the Goddess', the very embodiment of fertility in all its aspects, including creativity. ${ }^{64}$

It can be argued that the contemporary need for healing and the quest for rebirth in the globalised world leads disoriented people to look for a protective mother, if not a womb in which to be born to a new life. Mother Ireland seems currently to be revisited to suit that purpose. The testimony of Irish painter Fiona Marron is significant in that respect. In an article entitled 'Meeting with remarkable Sheela-na Gigs', she presents Sheelas as the representation of the Cailleach, the Irish crone or hag, 'the old woman who gave birth to all races of people', but also 'the creator and devourer of the world, a symbol of the great mother in continuous cycles of life, death and rebirth.' To her, she is also 'a bridge between pagan and Christian culture. ${ }^{65}$ Fiona Marron actually chose the Burgesberg (Tipperary) Sheela as her 'Soul Carrier' 'because practically all of her had been eroded except her vulva, which she held preciously with her fingers'. And she concludes: 'Her vulva became her soul-centre for me. ${ }^{36}$ She likes the idea that Sheelas 'represent the earth mother waiting to be fertilised by

62 M. Macha Nightmare, in Monaghan (ed.) (IS), p. 296.

63 Mary Condren, 'Soulsmith for the New Millenium', in Monaghan (ed.) (IS), p. I22.

64 Barbara Callan, 'In Search of Crios Bríde', in Monaghan (ed.) (IS), pp. 135-6.

65 Marron, 'Meetings with Remarkable Sheela-na-Gigs', in Monaghan (ed.) (IS), p. 299.

66 Marron, 'Meetings', p. 302. 
the sky father', which, she thinks, may suggest a graphic interpretation of Newgrange. A similar theory is implied by Mary Condren's interpretation of the ruins of a twelfth-century church at Killnaboy (County Clare) since, to her: 'the congregation enters the womb of the church through the arched entrance above which a wonderful Sheela is perched. ${ }^{67}$ The universal Church and the universal mother become one and they carry the promise of a new humanity in their womb.

In this area as in many others, globalisation and localisation are complementary. Universal myths may be embodied in any culture; but Ireland clearly holds a special position in this perspective. Patricia Monaghan argues that if the spiritual heritage of Ireland is adapted to suit late modern needs, it may actually contribute to the regeneration of the global spirit. Indeed, to her, 'spiritual challenges are best met by mining the past while embracing the future. ${ }^{68}$ For that reason, she says, in the new global culture the Irish spirit must be invented anew.' Inventing on the basis of fake authenticity is therefore on the agenda. Adepts of loose contemporary spiritualities unashamedly praise the virtues of imagination when it comes to creating viable individual and/or universal identities for the future. The archdruid of ADF answers the question: 'Are Neo-pagan Druids "Real" Druids?' in the following manner:

[...] There are no 'real' druids left. The Paleopagan Druids were wiped out centuries ago and only fragments of their traditions survived, despite the claims of some would-be con-artists.

Spiritually, we believe that we are following the paths once trod by our namesakes and that no other name is nobler and suited to our modern intentions - and that makes us real as far as we are concerned. ${ }^{69}$

The Pontifical Council for Interreligious Dialogue is appalled at the success of religious movements which, as Paul Heelas says, do not 'demand any

67 Marron, 'Meetings', p. 304.

68 Monaghan $(I S)$, p. 282.

69 http://www.adf.org/. 
more faith or belief than going to the cinema. ${ }^{70}$ Christian religions now seem unable to provide an adequate answer to people's needs. 'The search which often leads people to the New Age', the authors of the Vatican's 2003 report on New Age comment, 'is a genuine yearning: for a deeper spirituality, for something which will touch their hearts and for a way of making sense of a confusing and alienating world. ${ }^{71}$ To French philosopher Jacques Derrida, commenting on contemporary religious phenomena, no talk about religion can be dissociated from the hope of salvation. ${ }^{72}$ Contemporary religious quests must therefore be understood as desperate attempts to be rescued from the evils of the world we live in and to which traditional religions are historically associated. The adepts hope a form of reinvented salvation will ensue. To many, the global Irish spirit may guide the alienated to a true Land of Promise.

70 Paul Heelas, The New Age Movement. The Celebration of the Self and the Sacralisation of Modernity (Oxford: Blackwell, 1996), p. 173.

71 Pontifical Council for Interreligious Dialogue, p. 4.

72 Derrida, Foi et raison, pp. 9-10. 


\section{In at the Death: The French Press and the Celtic Tiger}

GRACE NEVILLE

Over many centuries, French visitors to Ireland have filled countless rich volumes with their first-hand observations on 'la verte Erin': they have bequeathed to us a wealth of details on the Irish themselves, what they looked like, their clothing, housing, customs, pastimes and beliefs, Irish flora, fauna and awful weather, along with persistent hopes for salvation through Napoleon. ${ }^{1}$ The kaleidoscope of early French memories includes slated roofs that look like fish scales, windows that look like guillotines and freckles that look like trout mottling. Much of these pre-modern memories are (refreshingly?) politically incorrect: Irish people have distended lips due to speaking Irish, Irish women allow their breasts to hang loose, Cork is full of mad people wandering the streets. ${ }^{2}$

Especially since the Romantic movement in the nineteenth century, we have become accustomed to a certain kind of stylised lyrical description across a range of genres including fiction and non-fiction, with Ireland transformed into a cornucopia of clichés reprised to great effect by modern tourist advertisements: Ireland (and the Irish) are wild, untamed, shaped by nature rather than by nurture, beautiful and doomed. In haunting landscapes, the inhabitants are either happy (poor but happy because

I See inter alia the excellent chapter by Jane Conroy, 'Entre Réel et Imaginaire: Les Voyageurs français en Irlande, 1650-1850', in Paul Brennan and Michael O’Dea (eds), Entrelacs franco-irlandais. Langue, mémoire, imaginaire (Caen: Presses Universitaires de Caen, 2004), pp. 45-64.

2 See especially the pre-nineteenth-century French texts in Joachim Fischer and Grace Neville, As Others Saw Us: Cork through European Eyes (Cork: Collins Press, 2005). 
they know no better) or, more often, wretched and impoverished, the very embodiment of British colonial tyranny. Pace the adage that my enemy's enemies are my friends, French commentators feel free to heap all responsibility for Ireland's woes onto 'le perfide Albion.' In this context, reflections on economic matters are a constant, with early French commentators providing invaluable, detailed first-hand accounts of a wide range of commercial activities from the international butter and meat trade in Cork to the economic boom in Belfast. The economic stagnation of much of the nineteenth century is captured by visitors as eminent as de Tocqueville and Montalembert. The economic sluggishness of the newly independent state fills countless pages down to recent decades. Pity, anger, disdain and disbelief mark many of these commentaries. However, with the emergence, from the dismal undergrowth, of the Celtic Tiger in the I990s, everything changes. ${ }^{3}$ The binary opposites of 'poor-but-happy' fade, leaving the scene clear for something radically different. Over the past decade in particular, Ireland's 'Celtic Tiger' has featured so prominently in the French press that it risks joining the compendium of Irish clichés alongside bad weather, red hair and pints of Guinness. This chapter will analyse the rise and fall of the Celtic Tiger as depicted in the French press, primarily in the columns of Le Monde $e^{4}$ since 2000.

Attitudes vary to Ireland's meteoric transformation into a success story from an economic disaster spanning the centuries. In the first instance, there is astonishment that Cinderella is now the princess, that the youngest family member has ended up - in true fairytale fashion - outstripping her older brothers and sisters. Ireland is hailed as:

[the] Singapore of Europe, [le] Singapour de l'Europe (M, 6 January 2004) top of the class in the European economy, meilleur élève de l'économie européenne (M, 24 January 2006) économie, état, société (Caen: Presses Universitaires de Caen, 2007).

4 All my references to Le Monde will be abbreviated to $M$, with date of edition supplied in brackets. 
for over a decade now, the 'Celtic Tiger' has been galloping at top speed to the astonishment of Europe, voilà plus d'une décennie que le 'Tigre celtique' galope avec vélocité en étonnant l'Europe ( $M, 29$ May 2007).

Brigid Laffan's explanation for the Celtic Tiger ('when a country is small, it had better be intelligent', lorsquion est un petit pays, il vaut mieux être intelligent, $M, 6$ January 2004) finds immediate approval, unsurprising in the country that often identifies itself with little Astérix facing down the might of the Roman Empire: for, as Astérix always knew, brains inevitably count more than brawn. ${ }^{5}$

Then there is curiosity about how exactly this transformation was achieved (with a sense that French readers might wish to share in this insider information). There is much talk of partnership, with particular focus on former Taoiseach Bertie Ahern's famed negotiation skills (le modèle Bertie, $M, 29$ May 2007). Credit is paid to the reputed excellence of second-level education $(M, 29$ May 2007) and to the substantial investment made in education and training. The role played here by Ireland's tax regimes is highlighted:

[Ireland] remains the most financially attractive country in Europe, if only because of its low corporation tax: 12.5\%, whereas in France it is 33\%, ['Irlande] reste le pays d'Europe au plus fort pouvoir attractif: ne serait-ce quén raison de sa fiscalité très faible pour les entreprises: 12,5\% alors quien France elle est de 33\% (M, 22 May 2008).

Readers are also reminded that Ireland did well economically out of Europe as it played its cards intelligently: perhaps a coded message to any Eurosceptic readers out there ( $M$, January 2004).

So exemplary is this Irish transformation that it is constantly presented as a model that could be emulated back in France. One of the most interesting articles here, penned by le Président de la Région Bretagne, Jean-Yves Le Drian, is remarkable for a number of reasons, not least of which is the fact that Ireland is mentioned in only one paragraph (and this towards the end of the article) although it is clearly the inspiration from the title onwards:

5 See Alain Duhamel, Le Complexe d'Astérix. Essai sur le caractère politique des Français (Freiburg: Heider, 1985). 
'De la Breizh Touch au Breizh fighting spirit' (Libération, i4 December 2007). Le Drian proudly puts forward his region - so long associated with poverty and emigration - as a model for the rest of France and Europe:

Britanny can become a tiger, an engine for growth for France and Europe as well as for numerous other regions within France, La Bretagne peut devenir un tigre, un moteur de croissance pour la France et l'Europe commenombre d'autres régions de France (Libération, I4 December 2007).

Le Drian's homage to his native region would need only minimal tweaking to function as a paean to modern Ireland. Brittany was for so long 'the daughter of penury' (longtemps fille de la misère), ravaged by seemingly endemic poverty and mocked for its perceived backwardness: 'some people think that Brittany equates only with pigs and pollution', certains pensent que la Bretagne rime avec seulement 'cochon' et 'pollution'. Ireland and Brittany are alike down even to details of exactly who emigrated: when reading of Brittany's much ridiculed Bécassines who 'servaient les riches Parisiens', one cannot help recalling Ireland's 'Bridgets', young Irish domestic servants frequently mocked in the very homes of the American bourgeoisie for whom they worked. Brittany is a latter-day (former?) colony whose relationship with Paris recalls Ireland's relationship with London: 'we have polluted our land, our water in order to feed France', nous avons dégradé nos sols, nos eaux, pour nourrir la France. However, if - in so many ways Brittany is a mirror image of Ireland, it too - just like the unnamed Ireland, and well before the emergence of Ireland's Tiger - could always call upon its people's same never-say-die attitude:

This was without taking into account the will of men and women who could not resign themselves to seeing their region die. From all political horizons and from all sectors of the workforce, Bretons came together from the r950s onwards to present their demands and their development plans to successive governments. That was the spark that marked the revival of Brittany. Other factors included a strong birth rate, the return of retired people and of Bretons in their thirties.

C'était sans compter la volonté d'hommes et de femmes qui ne pouvaient se résigner à voir mourir leur région. Venus de tous les horizons politiques et de tous les secteurs d'activités, des Bretons se sont rassemblés à partir des années so pour porter leurs revendications et leurs plans de développement devant des gouvernements successifs. C'est cette étincelle 
qui a sonnéle réveil breton. Natalité dynamique, retour des jeunes trentenaires Bretons, arrivée de retraités (Libération, ${ }_{4} 4$ December 2007).

Strong traditions and rich history are not synonyms of rigidity, however: on the contrary, Brittany is strong enough to reinvent itself without losing any of its cultural wealth:

It is not only a land of traditions and of stories. It is also a modern, innovative region. Brittany is changing. The high quality of our researchers in marine and plant biotechnologies, of our imaging and acoustic laboratories, of our agro-industrialists, amount to advantages that provide Brittany with the keys to growth and employment, while all the time respecting who we are. Because Brittany meshes tradition with modernity, innovation with history.

Ce n'est pas qu'une terre de traditions, d'histoires. C'est aussi une région innovante, moderne. La Bretagne change. La qualité de nos chercheurs en biotechnologies marines et végétales, de nos laboratoires d'imagerie et d'acoustique, de nos industriels de l'agroalimentaire, sont des atouts qui donnent à la Bretagne les clés de la croissance et de lemploi, dans le respect de ce que nous sommes. Car la Bretagne conjugue tradition et modernité, innovation et histoire (Libération, I4 December 2007).

The message is clear: the Celtic Tiger is alive and well and living not just in Ireland but equally in the Celtic realm of Brittany. Brittany and Ireland fuse into a single unified source of inspiration ('ce trait de caractère celtique') shedding light not just on France but further afield, causing other tigers neither Irish nor Breton - to emerge in the recent European Union accession states, 'les tigres de l'Europe de l'Est' (M, 27 April 2008).

In general terms, up to the summer of 2008 , most articles on Ireland's Celtic Tiger are positive and upbeat. They are full of barely disguised messages for French readers on the Celtic Tiger mentality seen as a model that could usefully be adopted in France. Typical of these is an extensive article entitled 'A One-way Ticket to Ireland' (Aller simple pour l'Irlande, M, 22 May 2008). It hails Ireland as the new California:

a European-style 'American dream', un 'american dream'à l'européenne, an Eldorado for anyone with flair, un eldorado pour ceux qui ont du flair.

Mainland Europeans flock there as if on some latter-day gold rush (á la conquête de l'ouest). French citizens living in Cork, Dublin or on the 
banks of the Erne become young Midases making sudden fortunes unheard of in France:

Everything reeks of money, artifice and globalisation [...] The Irish Revolution has taken place, but not the one we expected. Instead, it's the money revolution [...] There is so much money here that people no longer know what to do with it.

Tout sent le fric, le toc et la mondialisation [...] la révolution irlandaise a eu lieu. Pas celle que l'on attendait. Celle de l'argent [...] Il y a tellement d'argent que les gens ne savent plus quoi en faire (M, 22 May 2008).

It is the new Irish mindset of the Tiger cubs - imitated by these young French entrepreneurs - that explains the rise of the new Ireland:

Young, ambitious, outspoken people full of dreams and ready to grasp at life, jeunes gens aux dents longues et au parler libre, prêts à croquer la vie, tout imbibés de rêves (M, 22 May 2008).

This Ireland has an open, energetic, can-do attitude that commentators declare unknown in France. Ireland's future is ahead of it, France's is already over: 'here everything is to play for ... in France it's already over, ici tout est à inventer ... En France c'est déja fait. Just as Ireland is reinventing itself, so too can its cubs, Irish or immigrant:

You have a kind of mental freedom there that we don't have. In France, everything is fossilised: you're born something and you stay something ...

On y trouve un espace mental que nous n'avons pas. Chez nous, la société est figée: on naît quelque chose et on reste quelque chose ... (M, 22 May 2008).

Thus, in Ireland, a finance graduate from Marseille makes a fortune selling sex toys, an arts graduate from Paris holds a senior post in IT, a young lawyer from Toulouse works in HR ... All that is required is a strong work ethic:

In Dublin, you are given a chance at every turn, at every level. You are not judged by your face or the topic of your Masters [...] but on your ability to work hard.

A Dublin, on vous donne votre chance à tout moment, à tout niveau. On ne vous juge pas sur votre faciès ou sur le sujet de votre master [...] mais sur votre capacité à bosser ( $M, 22$ May 2008). 
That said, the Celtic Tiger is not without its warts. Sudden riches breed racism, a trait unheard of in the earlier accounts of 'la verte Erin' where French commentators stress that spectacular poverty and spectacular hospitality go hand-in-hand. The Irish Ferries' decision to replace Irish workers with lower paid non-nationals generates much interest and is seen as indicative of profound changes in Irish society:

xenophobic feelings are coming to the fore with the Celtic Tiger's sudden, brutal discovery of mass immigration, les sentiments xénophobes progressent dans ce 'Tigre celtique' qui découvre brutalement l'immigration de masse ( $M$, , December 2005).

And for all its sudden wealth, Ireland is still hampered by 'la misère des services publics', much to the amazement of a French reporter for whom a properly functioning public infrastructure that is not a luxury or an option but quite simply a basic right ( $M$, I5 May 2008).

However, in their assessments, Le Monde's journalists never abandon their critical faculties; their fascination with the Celtic Tiger is tempered with caution and ambiguity. The Irish tiger cubs at play resemble frantic Romans in the dying days of their empire:

Girls wild and half drunk [...] dripping with gloss, in their micro-skirts and shiny shoes [...], their backs bare, their breasts on show [...] Sex toys have become commonplace [...] just open any girl's handbag and you'll see that she has one, I swear!

Les filles rebelles et à demi-saoules [...] dans leurs jupes trop courtes [...] dos nus, le sein nonchalant, gloss à gogo et chaussures brillantes [...] Les sextoys, c'est devenu un lieu commun [...] tu ouvres le sac à main de n'importe quelle gonzesse, elle en a un, parole! ( $M, 22$ May 2008).

No longer a country of saints and scholars, Ireland has cast off its identity formed out of a slow accretion of layers of complex history. It is now a country turned not towards the past as so often throughout its history or even towards an unknown future: it lives resolutely and unapologetically in the present, caught up in the first wild party of its entire life: l'Irlande vit au présent. The Celtic Tiger, with its new value system, has reinvented it as 'this island where English is spoken and hardly any taxes are paid', cette île où l'on parle anglais et où l'on paye si peu de taxes. Le Monde clearly sees these changes as a form of impoverishment. The term 'philistines' hangs in 
the air... Ultimate irony: with its new-found wealth often built on dubious work practices like those of Irish Ferries, Ireland is the new coloniser $(M$, Io December 2005). Fintan O'Toole is quoted, lambasting this

unknown Ireland: the Ireland that exploits migrants who get to do all the awful work in sectors where the country is experiencing a worker shortage, Irlande inconnue: celle de l'exploitation des migrants, corvéables à merci dans les secteurs où le pays souffre de main-d'auvre ( $M$, io December 2005).

Thus, the positive terms used in this account of an IRA protest against the proposed visit by Queen Elizabeth reveal the journalist's admiration and even his relief:

A dozen hardy Gaels in workers' jackets, and a beautiful, dignified old woman with grey hair, try to remind the human flood that once upon a time this was a country where people fought for something other than money.

Une douzaine de robustes Gaels en parkas de travailleurs et une vieille femme belle et digne aux cheveux gris tentent de rappeler à la marée humaine quil fut un temps où le pays se battait pour autre chose que l'argent (M, 22 May 2008).

For almost a decade before the current economic meltdown, Le Monde had been casting a cold eye on the health of the Celtic Tiger. Already in 2000 , an article headlined 'Is Ireland soon to be victim of its success?' (L'Irlande, bientôt victime de son succès?) pointed to rising inflation rates and declining purchasing power ( $M$, 19 September 2000). The flow of jobs from Ireland to low-cost bases in Asia is also highlighted ( $M, 27$ January 2004). In 200I, in a strongly worded article, Le Monde reported that 'Brussels lambasted the bad example of spendthrift Ireland' (Bruxelles fustige le mawvais exemple de l'Irlande 'dépensière') but that Ireland was unapologetic in the face of Brussels' unprecedented criticism of a national budget ( $M$, II February 200I). More recently, Ireland's new identity - for instance as a country of net immigration - is cast as perhaps just a passing aberration: Le Monde reports an OECD finding that after five years of residency in Ireland, 60 per cent of immigrants to Ireland leave: a higher statistic than that quoted for any other country ( $M$, I6 September 2008). Similarly, the slowdown in the Irish economy already evident in early 2008 means that, according to an ESRI report quoted on 24 June 2008 : 
Ireland which had welcomed so many immigrants in recent years, especially whole hosts of American and European expatriates, may become once more a country of emigration: the ESRI has predicted that 20,000 people may leave next year. L'Irlande, qui avait accueilli de nombreux immigrés ces dernières années, et notamment des contingents importants d'expatriés américains et européens, devrait redevenir une terre d'émigration: elle devrait enregistrer 20 ooo départs nets l'an prochain, a prédit l'ESRI.

Headlines such as 'Ireland may experience in 2008 its first recession in 25 years' (L'Irlande pourrait connaître en 2008 sa première récession depuis 25 ans, $M$, 24 June 2008) and soundbites such as 'Ireland's crash landing' (Irlande: atterrissage brutal, M, 27 April 2008), along with entire articles, warn of the threatened implosion of the Celtic Tiger economy in early/ mid-2008:

The 'Celtic Tiger' has taken the full brunt of the credit crisis, the downturn of the construction market and the strength of the euro.

Le 'Tigre celtique' est frappé de plein fouet par la crise du crédit, un marché immobilier en pleine déprime, et la force de l'euro (M, 27 April 2008).

The party may indeed be over, concludes Le Monde:

The impact would be all the more painful given that up to now Ireland has been recording some of the highest growth rates in Europe. At the start of the decade, this exceeded $10 \%$, and was still as high as 5.3\% last year. But since the spring, a widespread sluggishness in the economy has undermined one of the Celtic Tiger's main engines of growth: household spending.

Le choc serait d'autant plus douloureux que l'Irlande affichait jusquici des taux de croissance parmi les plus élevés en Europe. Celui-ci avait dépassé 10\% au début de la décennie, et sélevait encore à 5,3\% l'an dernier. Mais depuis le printemps, la morosité s'est répandue dans l'économie et a sapé un moteur essentiel de la croissance du 'tigre celtiqué: la consommation des ménages ( $M, 24$ June 2008).

Less Midas than madness, the Celtic Tiger is seen in an increasingly unsympathetic light throughout 2008: it was not some economic miracle but a 'period of overheating that had created the "Celtic Tiger"' (période de surchauffe qui avait façonné le 'tigre celtique'): 
There is no equivalent in any other country to the Irish Government's response to the banking crisis. Their response reveals just how fragile this sector is in Ireland: small-scale banks in a country hit both by the bursting of the strong property bubble (as happened in Spain) and by an economy dependent on the external world, based primarily on exports and on inward flows of foreign investment $(89$ billion euro in 2007).

La réponse du gouvernement irlandais à la crise bancaire n'a pas d'équivalent dans d'autres pays. Elle exprime la fragilité spécifique de ce secteur en Irlande: des banques depetite taille dans un pays soumis à la fois à l'éclatement d'une forte bulle immobilière, comme en Espagne, et à une économie dépendante de l'extérieur, fondée principalement sur l'accueil des investissements étrangers et l'exportation (89 milliards d'euros en 2007) ( $M,{ }_{3}$ October 2008).

Annoyance that Ireland seems to be getting away with flexing European tax legislation, going it alone and leaving France and other European countries in its wake, explains the strong sense of unfairness that permeates many of these articles. However, with the Irish government's promise in October 2008 to support the Irish banking sector, calm analyses and mild disapproval are no more. Journalists reach for strong images of warfare in order to convey their disapproval: thus, Taoiseach Brian Cowen is said to have used a 'bazooka' to defend Ireland's banks ( $M, 2$ October 2008). Ireland's action is quite simply wrong, we are told:

In the first instance, is it necessary or sensible to follow the example of the Irish Government and to guarantee the liabilities of the banking system in its entirety? The answer is no.

En premier lieu, est-il nécessaire ou même avisé de suivre l'exemple du gouvernement irlandais et de garantir les passifs du système bancaire dans son ensemble? La réponse est non ( $M, 7$ October 2008).

Mr Cowen's plan is based on a mad hypothesis which could irritate his European neighbours. (Leplan de M. Cowen s'appuie sur une hypothèse folle qui a de quoi énerver ses voisins européens, $M,{ }_{3}$ October 2008).

Ireland is now held responsible for the banking crisis threatening all of Europe:

The crisis was sparked off by Dublin's solo run when it unilaterally decided last Wednesday morning to underwrite for two years the entire deposits of all six main 
Irish banks. This amounted to a mere trifle of 400 billion euros: in other words, twice its entire GNP!

La crise est déclenchée par le cavalier seul de Dublin, qui décide unilatéralement mercredi matin, de garantirpendant deux ans l'intégralité des dépôts de six grandes banques irlandaises. Une bagatelle de 400 milliards d'euros, deux fois son produit intérieur brut! ( $M, 2$ October 2008).

The crisis reached the Eurozone, especially with the Irish government's decision to guarantee the deposits of its biggest banks.

La crise a gagné la zone euro, notamment avec la décision du gouvernement irlandais de garantir les dépôts de ses plus grandes banques (M, 7 October 2008).

Ireland's 'exceptionalism' as the European economy's star pupil has now given way to 'exceptionalism' of a different kind: 'In the financial crisis enveloping Europe, Ireland is doing its own thing' (dans la crise financière qui gagne l'Europe, l'Irlande joue en solo, $M,{ }_{3}$ October 2008). In an extremely volatile situation, Ireland - according to one headline - is creating panic by going it alone in the crisis' (sème la panique en jouant 'perso' dans la crise, $M,{ }_{3}$ October 2008). Less Celtic Tiger than Celtic Dragon, Ireland is now a violent, headstrong teenager intent on bringing the house down with no thought for anyone else. For what is dangerous for Ireland could be catastrophic for the rest of Europe:

The reality is more serious still: Ireland is adopting a non-cooperative attitude which risks attracting Europe's entire capital stock and destabilising its European neighbours.

La réalitéest encore plus grave: l'Irlande adopte une attitude non coopérative, qui risque d'attirer tous les capitaux d'Europe et de déstabiliser ses voisins de l'Union européenne ( $M, 2$ October 2008).

Ireland stands accused of lacking that archetypically English trait, "le fairplay':

'Unfair competition!', complained the British Bankers' Association which is worried at seeing depositors flock to its competitors.

'Distortion de concurrence!', a dénoncé l'association des banquiers britanniques (BBA), inquiète de voir ainsi les déposants séenfuir chez leurs concurrents $(M, 3$ October 2008). 
Ironically, the French journalist appears to sympathise more with 'le perfide Albion' than with its former colony, in this instance. The most excoriating attack on Ireland's action comes from MEP Alain Lamassoure, in an elemental fire-and-water image that encapsulates Ireland's perceived irresponsibility, short-sightedness and selfishness:

The Irish are putting out the fire in their own house by tapping in to their neighbours' water pump.

Les Irlandais éteignent l'incendie chez eux en se branchant sur la pompe à eau des voi$\operatorname{sins}\left(M,{ }_{3}\right.$ October 2008).

Ireland's new-found status is as Europe's spoilt, wayward child. Ireland is distancing itself from its former host, warns a headline in early June 2008: 'Irlande-Europe: problèmes de couple' ( $M$, II June 2008). Accusations of ingratitude and short memories are not far off: after all, it was Europe and specifically the European Union that allowed Ireland to 'play with the big boys' (jouer dans la cour des grands, $M$, in June 2008). As Jean-Luc Porquet remarks tongue-in-cheek:

They owe everything to Europe: their wealth over the past fifteen years when grants were showered on them, along with extraordinary agricultural assistance ... Shouldn't they say thank you?

Ils doivent tout à l'Europe: leur enrichissement des quinze dernières années, des subventions comme s'il en pleuvait, des aides agricoles miraculeuses... Ils devraient dire merci, non? (Le Canard Enchaîné, II June 2008).

However, far from displaying any solidarity with the Good Samaritans who helped it when it was destitute, Ireland now leads the way in a display of egoism:

The Irish example in deciding to guarantee the deposits of its largest banks must not be emulated. It is a dangerous, self-centred action.

La décision irlandaise de garantir les dépôts de ses plus grandes banques n'est pas un exemple à suivre. C'est un geste égoïste et dangereux ( $M, 7$ October 2008).

Ireland's new self-absorption explains why it did not even have the courtesy to inform its closest neighbours of its revolutionary rescue plan: Gordon 
Brown first heard of it on the radio ( $M, 2$ October 2008). Ireland had recently shown the way out of economic stagnation, to the extent that Lithuanian Ambassador to Ireland, Martins Lacis, could declare his mission to be 'study even more closely the secrets and tricks of the Celtic Tiger' (étudier d'encore plus pres les secrets et les ressorts du Tigre celtique):

\footnotetext{
'We have already carried out several visits to Ireland to observe at close quarters this small country which for us is one of Europe's finest success stories', 'Nous avons déjà menéplusieurs missions en Irlande pour observer de près ce petit pays que nous considérons comme l'une des plus belles réussites européennes'( $M, 27$ January 2004).
}

Just four short years later, Ireland again leads but this time by bad example. Its unilateral decision to support its banks represents a 'mé-féin' approach (une politique du chacun pour soi, $M, 7$ October 2008). Ireland could now lead the race to the bottom:

God helps those who help themselves is the optimistic version of every man for himself: a strategy [...] applied in haste by the Irish, 'aide-toi, le ciel t'aidera', version optimiste du sauve qui peut' [...] appliqué avec célérité par l'Irlande (M, 2 October 2008).

To quote Eurosceptic Philippe de Villiers, commenting on Ireland's rejection of the Lisbon Treaty: 'We are all Irish now' (Nous sommes tous des Irlandais, $M, 29$ September 2008).

Ireland's earlier lack of enthusiasm for the Lisbon Treaty (ce 'bof' européen, $M, 20$ February 2008) had generated bafflement tempered with not insignificant doses of admiration in the French media: it was interpreted as evidence of Ireland's irrepressible 'fighting spirit'. However, with Ireland's unilateral decision in October 2008 to support its banking sector, centuries of almost invariably benign French commentaries on Ireland now come shuddering to an abrupt halt. It could be argued that never before in the history of Franco-Irish relations has Ireland been so consistently and so unapologetically lambasted. Ireland's image has changed, changed utterly: no longer 'ailleurs' but an intrinsic element in a now globalised economic network, no longer an innocent, non-threatening source of beauty, exoticism and oddities (human and otherwise) but a threat to an unsuspecting 
'vieille Europe' that had, like some latter-day Pygmalion, showered every conceivable blessing on it, Ireland can no longer bask in the warm glow of admiration from iconic hibernophiles like Charles de Gaulle and Jacques Delors: instead, the places at the top table are now occupied by cold-eyed critics such as President Nicolas Sarkozy. It is possible that in the age-old Franco-Irish alliance, things may never be the same again. 


\section{Negotiating the Self: The Spectral Mobile Subject}

EUGENE O'BRIEN

Writing about Jacques Derrida after his death, Simon Critchley made the point that in his view Derrida was a 'supreme reader of texts'. Critchley went on to describe Derrida's legacy in terms of his distinctive mode of double reading which initially was attendant to the scholarly context of the piece of writing in question. This involves 'reading the text in its original language, knowing the corpus of the author as a whole, being acquainted with its original context and its dominant contexts of reception'. Critchley sees this as the first step in the process: it is a laying down of a 'powerful, primary layer of reading.' The second aspect of this double reading is what is more normally seen as interpretation or hermeneutic reading, where the text is 'levered open through the location of what Derrida sometimes called blind spots'. Many of his double readings turn around such blind spots in order to explode from within our understanding of a particular author. The key point is that the explosion has to come from within and not been imposed from without. It is an attempt to think 'the unthought within the thought of a specific philosophical text.'

This is as valid an account of this mode of French literary theory as I have seen and, in the course of this chapter, I would like to engage in precisely such a double reading of the phenomenon of globalisation as it affects Ireland. In this context, I will tease out the different valences of one relatively unthought aspect of globalisation - mobile technology and will attempt to show how this has affected the double reading of our human subjectivity as it is now constituted, what I call 'spectral mobile

I Critchley, Simon, 'Jacques Derrida', in Symposium, 8:I, 2005. http://muse.jhu.edu/ journals/theory_and_event/voo8/8.icritchley.htm. 
subjectivity'. I see the globalised subject as spectral because of the manner in which notions of presence have been deconstructed by mobile phones, text messages and virtual reality. For example, my image can be on video giving a talk in New York, whereas I can contemporaneously be texting someone from my office in Limerick, while also engaged in a conversation with a person in that office. So the question arises as to where, exactly, am I 'present'? And this technology also contributes to the 'mobile' aspect of my term, which derives from the way in which information and knowledge are all available to us on a mobile basis - no longer do we go to a specific place to make a phone call, or to use a computer or access the internet all of these are now freely available to us on mobile phones carried on our person.

The idea of the spectre is one which has haunted culture from time immemorial - it is the ghost, the revenant, the figure which is between living and dead, between the past and the future, and this spectrality is very much at the core of the relationship between globalisation and the subject. In Specters of Marx, Derrida discusses what he terms 'hauntology', in answer to his question: ' $w]$ hat is a ghost?'2 In this book, he discusses the spectrality of many areas of meaning, seeing ghostly hauntings as traces of possible meanings. But Derrida makes one important distinction, in that he sees spectrality and time as closely connected. He makes the point, speaking both of the ghost in Hamlet and the ghost that haunts Marx's Communist Manifesto (where the first noun is 'specter'), that: ' $[\mathrm{a}] \mathrm{t}$ bottom, the specter is the future, it is always to come, it presents itself only as that which could come or come back.' In this sense, hauntology suggests a movement between past, present and future and a process of constant negotiation.

2 Jacques Derrida, Specters of Marx: The State of the Debt, the Work of Mourning \& the New International, trans. Peggy Kamuf, intro. by Bernd Magnus and Stephen Cullenberg (London: Routledge, 1994), p. Io. 
Derrida traces the etymology of 'negotiation' to the Latin neg-otium: 'not-ease, not-quiet ... no leisure." He sees this '[no]-leisure' as the 'impossibility of stopping or settling in a position ... establishing oneself anywhere.' This process is typified by the image of a shuttle, going back and forth between different positions. ${ }^{5}$ He goes on to explain:

I appropriated the etymology for this new writing (ethical or political). Un-leisure is the impossibility of stopping, of settling in a position. Whether one wants it or not, one is always working in the mobility between several positions, stations, places, between which a shuttle is needed. The first image that comes to me when one speaks of negotiations is that of the shuttle, la navette, and what the word conveys of to-and-fro between two positions, two places, two choices. One must always go from one to the other, and for me negotiation is the impossibility of establishing oneself anywhere. ${ }^{6}$

This would seem to be a very postmodern and reflexive position, and given the current debates in Ireland about immigration, religion, identity and our place in Europe, pace the Lisbon referendum, a very contemporary one. However, Derrida is at pains to stress that this shuttling is not a free play of undecidability, where anything goes; rather it is 'always a determinate oscillation between possibilities. ${ }^{7}$ This oscillation is part of the negotiation that I see as central to the interaction between the technological and the personal; the local and the global; the cultural and the political. As Derrida puts it, the word must 'negotiate its usage's in debate, and this ongoing negotiation is probably the best way to view the relationship between the local and the global and between the Irish mobile spectral subject and the processes of globalisation.

4 Jacques Derrida, 'The Deconstruction of Actuality', in Negotiations: Interventions and Interviews 1971-200I, ed. and trans. Elizabeth Rottenberg (Stanford: Stanford University Press, 2002), p. II.

5 Derrida, 'Deconstruction of Actuality', p. I2.

6 Derrida, 'Deconstruction of Actuality', p. I2.

7 Jacques Derrida, Limited Inc., trans. Samuel Webber (Evanston, IL: North-Western University Press, 1988), p. 148.

8 Derrida, 'Deconstruction of Actuality', p. I2. 
Writing in Deconstruction in a Time of Terror, Derrida makes the following points about globalisation:

And yet wherever it is believed globalization is taking place, it is for better and for worse. For better: discourses, knowledge, and models are transmitted better and faster. Democratization thus has more of a chance. Recent movements toward democratization in Eastern Europe owe a great deal, almost everything perhaps, to television, to the communication of models, norms, images, informational products, and so on. Nongovernmental institutions are more numerous and better known or recognized. Look at the efforts to institute the International Criminal Tribunal. ${ }^{9}$

In other words, to see globalisation as either good or bad is overly simplistic. Like so many of its elements, globalisation itself is both spectral and nomadic, moving to bring benefit and loss to different sectors of the global economy through processes of negotiation.

Writing about knowledge, technology and the globalised world, István Mezgár notes that the new world of knowledge-based industries revolves around precognition and adaption. He goes on to make the telling point that:

the new world of Technologies (electronic and mobile) needs very high levels of adaptability to incorporate dynamic changes into the business and information architecture and the ability to develop systems that can be readily adapted for the dynamically changing business environment. ${ }^{10}$

He posits the two main views of knowledge management that are current in a globalised culture - one which notes that it is 'possible to represent knowledge in forms that can be stored in computers' and the other which

9 Jacques Derrida, 'Autoimmunity: Real and Imagined Suicides: A Dialogue with Jacques Derrida', in Giovanna Barradori, Philosophy in a Time of Terror: Dialogues with Jurgen Habermas and Jacques Derrida (London: University of Chicago Press, 2003), p. 123.

Io István Mezgár, 'Security Technologies to Guarantee Safe Business Processes in Smart Organizations', in Cornelius T. Leondes, Intelligent Knowledge-Based Systems: Business and Technology in the New Millennium (London: Kluwer Academic, 2005), pp. $246-87$, p. 258. 
argues that 'knowledge resides in the user's subjective context of action based on the information stored in the computer'. For Mezgár, mobile technology is an important driver of globalised modes of production and interaction because they allow for the connection of the individual to the internet in terms of Wireless Application Protocol (WAP) which provided a platform for the connection of computers, hand-held computers, laptops, mobile phones and smart phones.

The importance of mobile communication as a constituent of the globalised world in which we live is underlined by its habituation, and by the fact that we are actually surprised by the penetration of communications technology in our lives. Residing in our pocket or in our handbag, we now have radio stations, $\mathrm{MP}_{3}$ players, GPS connections, television and webcasts, access to the internet and numerous forms of messaging possibilities. And these messages are not just personal, as financial and market-based data is also transacted at a giddying rate through PC networks, and the virtuality of the financial markets has become a byword for globalised industries. Ironically, in the Financial Services Centre in Dublin, there is very little actual cash to be found: all of the services and the products are virtual.

What this means, in effect, is that we are now transnational citizens of a globalised economy, with almost pervasive interconnection with other places, cultures and people. The mediatised negotiation of these connections has often been the subject of discussion, as PC terminals seem to have taken the place of currency exchanges, and the amount of actual cash notes in the world is dwarfed by the virtual billions that are traded and transacted in the global financial markets. Clearly, the role of technology in the global socioeconomic habitus is crucial, and has been the subject of much discussion in 2008-9. In a global context, the crash of various banks and insurance companies such as Lehman Brothers, Federal National Mortgage Association (FNMA) and Federal Home Loan Mortgage Corporation (FHLMC), more commonly known as Freddie Mac, in 2008 in the United States, and AIG and Northern Rock in the United Kingdom, meant that the effect of globalisation was felt very sharply in Ireland. The response to this crisis was suitably speedy, as befits a financial sector where billions and trillions of dollars are transferred across the globe at fiber-optical speeds. The United States government has guaranteed its sub-prime mortgage market to the 
tune of $\$ 700$ billion while six European governments coordinated a $€ 2$ trillion rescue plan. A guarantee by the Irish government of some $€ 400$ billion meant that we followed suit in this process.

But in this globalised financial sector, one question worthy of being asked is the actual status of such sums of money? Of course, in terms of ontological status this question is easy to answer - there is no actual location where $€ 2$ trillion, or even $\$ 700$ billion, actually exists. These amounts of money are ontologically virtual, they are spectral and very mobile. There is no bank or financial institution where this money is to be found. It is a virtual, hauntological, sum of money created through various symbolic exchanges and negotiations, which are part and parcel of transnational and globalised financial markets. It is endlessly mobile, shifting from bank to bank, as a series of signifiers, wherever interest and investment rates are better. This is spectral capital that has an existence in the ultimate binary opposition that structures our global economy: the ' $\mathrm{I}$ ' and 'o' of the binary computer code.

However, it would be a mistake, and one that is often made in connection with any discussion of French postmodern theory, to suggest that these virtual, spectral, mobile networks of financial transactions have no actual effect in the real world, because they do. At the higher end of the system, billions of euro can be guaranteed through a flick of a finger on a mouse, but at the lower end there are hard financial realities that are far from virtual. Thus the Irish government can guarantee the Irish banks' future with a virtual sum of $€ 400$ billion, in the knowledge that this actual amount of money is not to be found anywhere. However, in the Irish budget in October 2008, so stringent were the effects of the credit crunch, itself an effect of economic globalisation, that the government suggested taking free medical cards away from all of its citizens who were over seventy as a way of saving some $€$ Io० million. It is interesting that a change in figures in the spectral symbolic order of the budget provisions and currency thresholds can make such an actual difference to people living in the country. Here, the spectral financial markets have haunted the government and have caused the usual effect of spectres - fear and terror - in the population of Ireland who are over seventy years old. 
However, the response to this crisis is a further example of spectral mobility, as pensioners travelled en masse to Dublin to voice their frustration and anger at this treatment and they used the power of technology, specifically the media, to argue their case. And these spectral (in a double sense because they are nearer to death than most of the population), mobile (as they travel to Dublin), subjects are examples of globalisation as a form of subjective empowerment, as they refuse to listen to the structural voices of the government. Indeed, after these demonstrations and a general media outcry in the country about the indiscriminate nature of the loss of entitlements - the original income threshold was $€ 240$ per week for a single person and $€ 480$ per week for a couple - the Taoiseach announced that the government had decided to raise these figures to $€_{700}$ and $€_{1}, 400$ respectively, thus removing all but a minimal number from access to free medical care.

This is another aspect of the negotiations of the global; as more people are empowered through communication and technology, so their voices are louder, and they see that they can change the structures which constitute them. Paula Murphy makes this point about the symbolic order of contemporary Ireland:

The shifting symbolic of Irish society [...] does not manifest itself as a linear trajectory, but consists of numerous advances and retreats that occur when the global symbolic of the Western world clashes with its national and local counterparts. ${ }^{11}$

Generally Ireland has had very positive economic responses to globalisation. G. Honor Fagan has made the point that in a survey in $200 \mathrm{I}$ by the American magazine Foreign Affairs, Ireland came out at the top of a world globalisation index. She went on to say that the indicators used were information technology, finance, trade, travel, 'politics' and personal communications, 'all designed to evaluate the degree of global integration', and the success of Ireland's economic policy was such that by $200 \mathrm{I}$, finan-

II Paula Murphy, The Shattered Mirror: Irish Literature and Film, Iggo-2005 (Newcastle: Cambridge Scholars Press, 2008), p. 88. 
cial inflows and outflows were 'the largest in the world in terms of gross domestic product.' ${ }^{12}$

So Ireland, while now a victim of the downturn in globalised economic processes, has for quite some time been very much a global success story. Indeed, one could make the point that through globalisation, technology and the spectral movement of capital, Ireland had developed from a premodern existence, bypassing the classic features of modernity, such as the rise of the bourgeoisie, strong manufacturing industries and a slow process of secularisation, and had become postmodern almost in spite of itself. Perhaps the only area of the country not affected by this was Northern Ireland, dogged by postcolonial and post-imperial violence for over thirty years, but even here, through the peace process, which was globally empowered through the good offices of Bill Clinton, George Mitchell and the European Union, the violence was finally ended, and its end was coterminous with the flourishing of the Celtic Tiger. As Murphy observes: 'there has been a striking decrease in the importance of Northern politics as a theme for Irish writers and filmmakers. It is rarely mentioned, or if it is, only to remark on its distance from the lives of the characters in question. ${ }^{, 13}$ And it is notable that in the media, Northern Ireland is no longer a central news item. In terms of a negotiated Irish globalised identity, Northern Ireland has lost its metonymically central status as a key signifier of nationalism and postcolonialism.

Part of the reason for this is that through mobile technology, and mediatised access to a broader sense of community, the intrinsic binary of nationalism and unionism has been dislocated. Just as the financial system of Ireland has been changed, for better and for worse, by the spectral movement of capital in our technologically driven globalised economy, so, I would argue, have our individual notions of selfhood and our sense of human interaction been equally altered by globalisation. Mobile

I2 G. Honor Fagan, 'Globalized Ireland, or, Contemporary Transformations of National Identity?', in C. Coulter and S. Coleman (eds), The End of Irish History? Critical Reflections on the Celtic Tiger (Manchester: Manchester University Press, 2003), p. IIo.

Murphy, The Shattered Mirror, p. 174. 
technology ensures that the influences of globalisation are ongoing and mutually transformative. I will further argue that mobile technology, far from being something superadded to our sense of subjectivity, has now become a constituent factor of that subjectivity. The beep of our mobile phones, and the ongoing texting of others (six million texts were sent in Ireland in 2006 with almost nine million being sent in 2008), defines a quantum shift in our relationships with the other, on a micro level, and with the global other on a macro level. I will also suggest that this sense of being constantly contactable has altered our sense of ourselves to a very significant degree. The relationship between self and other has been ontologically altered though the hauntological processes of technology. It is my contention that mobile technology is a core constituent of the symbolic constitution of contemporary Irish men and women. As Murphy puts it:

Only a few generations ago in Ireland there was no electricity. Cable television and internet access were as yet unthought-of. The Irish citizen of the early 20 th century experienced a predominantly localized rather than globalised culture. For the generation of the third millennium, the constant exposure to global culture has opened vistas of possibility that were previously unimaginable. In Lacanian terms, the imaginary identifications of this generation are no longer confined to local or national figures: on the contrary, the Other of the third millennium is a global Other. ${ }^{14}$

The negotiations involved in this process are complex and multi-layered, and I would draw on the work of Arjun Appadurai to illustrate this point.

In his seminal essay 'Disjuncture and Difference in the Global Culture Economy', he argues that the relationship between the global and the local, and between capital and the subject, is one which defies definition: 'the new global cultural economy has to be seen as a complex, overlapping, disjunctive order that cannot any longer be understood in terms of existing center-periphery models (even those that might account for multiple centers and peripheries).'. ${ }^{15}$ He goes on to postulate a new interactive negotiation

I4 Murphy, The Shattered Mirror, p. vii.

I5 Arjun Appadurai, Modernity at Large: Cultural Dimensions of Globalization (Minneapolis: University of Minnesota Press, 1996), p. 32. 
(and I use the word deliberately in its Derridean sense) between different aspects of the globalised world:

I propose that an elementary framework for exploring such disjunctures is to look at the relationship among five dimensions of global cultural flows that can be termed (a) ethnoscapes, (b) mediascapes, (c) technoscapes, (d)financescapes, and (e) ideoscapes. The suffix -scape allows us to point to the fluid, irregular shapes of these landscapes, shapes that characterize international capital as deeply as they do international clothing styles. These terms with the common suffix -scape also indicate that these are not objectively given relations that look the same from every angle of vision but, rather, that they are deeply perspectival constructs, inflected by the historical, linguistic, and political situatedness of different sorts of actors: nation-states, multinationals, Diaspora communities, as well as subnational groupings and movements (whether religious, political, or economic), and even intimate face-to-face groups, such as villages, neighborhoods, and families. ${ }^{16}$

And mobile technology, I would argue, produces this negotiation between these different '-scapes' by altering the very nature of what it means to be human. These interactive and multi-perspectival '-scapes' can be seen as broadly analogous to Pierre Bourdieu's concept of the habitus.

The habitus is the practical and unthought (and untaught) background: 'the habitus is necessity internalized and converted into a disposition that generates meaningful practices and meaning-giving perceptions; it is a general transposable disposition which carries out a systematic, universal application - beyond the limits of what has been directly learnt - of the necessity inherent in the learning conditions. ${ }^{17}$ As Bourdieu also explains: the conditionings associated with a 'particular class of conditions of existence produce the habitus, systems of durable, transposable dispositions, structured structures predisposed to function as structuring structures, that is, as principles which generate and organize practices and representation. ${ }^{18}$ Globalisation, the virtual world, mobile technology, hauntological presence - these are all part of the contemporary habitus. In psychoanalytic terms,

Appadurai, Modernity at Large, p. 33 .

I7 Pierre Bourdieu, Distinction. Translated by Richard Nice (Cambridge, MA: Harvard University Press, 1984), p. 170. 
one could make parallels between the habitus and what Jacques Lacan calls 'the big Other'. For Lacan, this is the way in which the symbolic order is experience by specific individuals: it is 'the nexus of social, moral and linguistics codes, in the gaze of which the individual lives, speaks and acts. ${ }^{19}$ This process of negotiation is facilitated through the ability of the individual to enact with his or her local and global community and to have an active role in the transmission of culture through mobile modes of production. Perhaps the most important aspect of our current globalised world is that of information. Time and again we hear about the 'knowledge economy' and the 'knowledge society', and this has now become a key economic driver in Irish society, a point made by Mezgár, as we recall in terms of the global economy in general. But knowledge now is a conflation of those different '-scapes' cited by Appadurai, and as he himself had noted, the imagination is now central to all forms of agency, is itself a social fact, and is the key component of the new global order.' ${ }^{20}$

In previous pre-mobile generations, the relation between the knowledge culture industry and the individual was very one-sided. The culture industry produced books, films, newspapers, television and radio programmes and the subject was the quasi-passive receptor of this process and of these ideological products. One thinks of the individual in Nazi Germany or Communist China where the s/he was constituted through the ideological bombardment of the culture industry, and where the means of cultural production were carefully guarded. In these cases the habitus or 'big Other' was carefully regulated and constructed. The individual was constructed as a passive recipient of such cultural coding, and his or her reactions were limited in terms of how he or she could affect the habitus or big Other of the regime in question. One thinks of the state of censorship that existed in the early Irish Free State, where foreign opinion was very carefully mediated through the established centres of power, namely church and state.

I9 Murphy, The Shattered Mirror, p. I2.

20 Appadurai, Modernity at Large, p. 31. 
Now, however, control of print and image have been deconstructed and liberated so that every owner of a mobile phone can take pictures and videos, and can broadcast these images and videos on YouTube on the internet. Before, the studio, the newspaper office and the relevant government department, all of which were in the service of a single monolithic authority, were the locus of the production of information. However in our globalised Ireland, the individual, the subject, is now the producer of information, and our globalised technological society and culture means that such production is now mobile and democratic. As Derrida puts it: 'information can and must transform itself; it can and it must serve - as it often has - knowledge, truth and the cause of the democracy to come.21 And my analysis of the contemporary mobile subject negotiates with Derrida's definitions and will be deconstructive in its epistemological structure. I use the term 'deconstruction' here in its technical as opposed to popular sense. Derrida argues that a new paradigm to begin, the older certainties and givens must be put into question and this is the mode of deconstruction that I advert to here.

Philosophically, deconstruction is important in its overall thrust towards the future, what Derrida has called the à venir:

What you need deconstruction for is to undo a number of presuppositions, prejudices and so on and so forth. But where you don't need to undo such things, you don't need deconstruction ... So it depends on the type of relationship that you have between interpretation and knowledge, and of course the more you rely on interpretative languages, on institutional practices and so forth, the more you need deconstruction. ${ }^{22}$

And in the case of attempting to analyse the effect of globalisation, deconstruction is crucial. There is very little morality to be found in globalisation because the word itself means so many different things to so many different people that it has almost become an empty signifier. The same is

2I Jacques Derrida, 'Open Discussion', in Jacques Derrida, Deconstruction Engaged. The Sydney Seminars, ed. Paul Patton and Terry Smith (Sydney: Power Publications, 200 I), p. 88.

Derrida, 'Open Discussion', p. ıı. 
true of the ongoing march of technology, itself a metonymic representation of globalisation, what Derrida terms 'technoscience and economic or telemedia globalization. ${ }^{23}$

Technology has the power to change our subjectivity. In this respect, technology can be seen as what Derrida terms a pharmakon. In 'Plato's Pharmacy', Derrida traces the rejection of the god Thoth's gift of writing by the Egyptian King Thamus. Thoth claims that his invention of writing is a pharmakon for memory and wisdom and offers his gift as a cure, but King Thamus returns it as a poison. Derrida observes the problematic aspect of the translation of pharmakon, as it signifies two opposite meanings - it translates as both cure and poison, and thus has both positive and negative connotations. ${ }^{24}$ Paul Virilio makes the same point with respect to technology, speaking of the accidents which are a necessary stage of technological development:

The accident is an inverted miracle, a secular miracle, a revelation. When you invent the ship, you also invent the shipwreck; when you invent the plane you also invent the plane crash; and when you invent electricity, you invent electrocution ... Every technology carries its own negativity, which is invented at the same time as technical progress. ${ }^{25}$

The pessimistic view of technology as poison has a long history. It has been seen as a very negative aspect of human development by various thinkers from popular and high culture. From Mary Shelley's eponymous monster, through to George Orwell's Big Brother, to the nearly omnipotent $\mathrm{Hal}$ in 20or: A Space Odyssey, to dysfunctional cyborgs in Blade Runner and Terminator, to the Borg of Star Trek and beyond, technology has often been seen as inimical to the development of humanity. Indeed, even the term itself can have negative consequences: we often say that we don't want to be 'too technical', or the term can be used as an argumentative escape clause: 'technically he was guilty but in actual fact he was innocent.' Indeed the

23 Derrida, 'Autoimmunity: Real and Imagined Suicides', p. I25.

24 Jacques Derrida, Dissemination, trans. Barbara Johnson (Chicago: Chicago University Press, 198I), pp. 7I-2.

Paul Virilio, Politics of the Very Worst (New York: Semiotext(e), 1999), p. 89. 
irony is that while our lives become suffused with technology, the term itself is still pejoratively seen as a negative. In all of the cultural fusions we see of the subject and technology - Darth Vader, Robocop, the Terminator in all of his (and her) incarnations - this fusion results in humans who move slowly, are robotic in their emotions, and are somehow lesser than the norm.

These technologically-enhanced creatures are seen as less than human and are invariably undone by their problems in relating to the other humans in their cultural contexts. In our culture, its ultimate synecdoche was the technologisation of death on the gas chambers, where instrumental rationality and the Fordist processes of mechanised capitalism, were brought to bear on the Nazi solution to the Jewish 'problem'. In these concentration camps, dead bodies become the product of the technological processes of train transport, cataloguing of people as commodities and bloodless gas chambers, where the dead, stripped of clothing, valuables and all marks of humanity, climbed on top of the dead in a pyramidal shape gasping for the last gulps of fresh air, a pyramid that facilitated the gathering of the bodies, and their transportation to the gas chambers, where the human was reduced to ashes through the processes of technology. Such instrumental reason was what drove Adorno and Horkheimer to publish their Dialectic of the Enlightenment, ${ }^{26}$ and to suggest and warn of the dangers of such technologisation of the human. Virilio, in his theory of technology and accidents, makes the point that now, with the advent of global technology, 'there is the risk not of a local accident in a particular location, but rather of a global accident that would affect if not the entire planet, then at least the majority of people concerned by these technologies. ${ }^{, 27}$ At a further level of pessimism, Virilio cites the case of Bob Dent, who was suffering from terminal cancer and who used a remote-control suicide device developed by his doctor Philip Nitschke, and parallels this with the case of the Russian chess grandmaster Gary Kasparov, playing a game against a computer Cumming (London: Verso, 1997). 
specially designed to defeat him. ${ }^{28}$ In these cases, the human is made lesser by technology, the pharmakon as poison would seem to haunt our study of technology

However, in the context of the pharmakon as cure, there is another perspective to be taken on the technical. Martin Heidegger, looking at the etymology of the term observed:

To the Greeks techné means neither art nor handicraft but rather: to make something appear, within what is present, as this or that, in this way or that way. The Greeks conceive of techné, producing, in terms of letting appear. Techné thus conceived has been concealed in the tectonics of architecture since ancient times. Of late it still remains concealed, and more resolutely, in the technology of power machinery. ${ }^{29}$

This notion of 'letting appear' is important in terms of how technology interacts with the human. In his groundbreaking The Political Unconscious, Fredric Jameson urged the reader and thinker to 'always historicize, ${ }^{30}$ and in the current historical context, our very humanity is in constant negotiation with technology. But as we noted at the beginning of the chapter, Derrida is at pains to stress that this shuttling is not a free play of undecidability, where anything goes; rather it is 'always a determinate oscillation between possibilities. ${ }^{31}$ And mobile technology, I would argue, produces this negotiation by altering the very nature of what it means to be human.

The either/or binary that I looked at earlier in terms of technology as a poison or cure, has been replaced by a more fluid relationship between the technical and the human. There is a Heideggerian revelatory function at work here as the connection between the subject and the other becomes more overt. And there is a similar process of negotiation going on here between the idea of a fixed phone and a mobile one. So we no longer ask who is speaking because we are now ringing a specific person, and not a

Paul Virilio, The Information Bomb (London: Verso, 2000), p. 5.

29 Martin Heidegger, Poetry, Language, Thought (New York: Harper and Row, 1975), p. 159 .

30 Fredric Jameson, The Political Unconscious: Narrative as a Socially Symbolic Act (Ithaca: Cornell University Press, 198I), p. 9. 
phone belonging to a house or place. When the phone is in one's pocket, all sorts of different behaviours accrue. For example, we no longer ask who is calling; instead we ask 'where are you?', as the location of the subject is no longer predicated by the location of the phone. In other words, the subject has become more nomadic due to the technology available, and the phone is now dictated by our location as opposed to vice-versa. Mobility is both caused by, and helpful for, mobile phone interaction - it is a negotiation between them.

In the globalised Ireland of today, we are engaged in a rapid technologisation process and it is my contention that this process is one of negotiation, whereby our very sense of being human in space and time, is being altered by the mobile technology that has become part and parcel of our lives. Culturally, spatially, temporally and politically, the self of contemporary Ireland is radically different to that of the previous decades or historical periods. I would cite Rosi Braidotti who talks about the feminist subject of knowledge in a way that parallels my own thinking:

The feminist subject of knowledge is an intensive, multiple subject, functioning in a net of inter-connections. It is non-unitary, non-linear, web-like, embodied and therefore perfectly artificial. As an artifact it is machinic, complex, endowed with multiple capacities for inter-connectedness in the impersonal mode. It is sexed, but it's all over the place. ${ }^{32}$

And it is to this end that I propose a definition of contemporary subjectivity in terms of the new relationship to the other and to the symbolic order. For Lacan, subjectivity is defined through a relation to the other through language and desire. In terms of our new mobile technology, our relation to the other - be that other people, the Symbolic other or language, is mediated through mobile technologies such as phones and SMS messages. I am suggesting that a definition of the way in which we enact with our global other through Appadurai's ethnoscapes, mediascapes,

32 Rosi Braidotti, 'Between The No Longer And The Not Yet: Nomadic Variations On The Body'. http://www.women.it/cyberarchive/files/braidotti.htm, 2007 (accessed 5 January 2009). 
technoscapes, finanscapes, and ideoscapes. I would see our subjectivity as more instantaneously connected with the other and therefore define it as a 'spectral mobile subjectivity', as mentioned above. That the acronym of this definition is SMS (also standing for short message service) is helpful because the SMS service has revolutionised the way in which we connect to the other. I realise these are large claims but I will attempt to illustrate them under three headings: time, space, and attitude to culture and cultural production. I will look at the mobile phone, satellite navigation and the internet as the indices of this negotiation. It is through this mobile technology that we are spectrally mediated and can affect change in our habitus and big Other.

The inter-connected subject that Braidotti adduces is a function of our mobile technology revolution. In his book The Transparent Society, Gianni Vattimo, the Italian media philosopher, advocates the 'hypothesis' that 'the intensification of communicative phenomena and the increasingly prominent circulation of information, with news flashed around the world (or McLuhan's 'global village') as it happens, are not merely aspects of modernization amongst others, but in some way the centre and the very sense of this process. ${ }^{33}$

Worldwide there will be nearly three billion mobile phone users by the end of 2008 , which means a penetration rate of 51 per cent. There will be 931 million new users over the next five years. Of the almost 700 million mobile phones sold last year, some 250 million had built-in cameras, while, significantly, only some 80 million digital cameras were purchased. These numbers, impressive enough in themselves, reflect some fundamental conditions and changes in the very nature of the individuals who use them. Today there are eight mobile phones for every roo people in Africa. In the Democratic Republic of Congo, that figure is two. These figures appear to be low, but in the Third World phones are widely shared. And the economic benefits of the spread of the mobile are double what they are in the rich world. As recent British research suggests, in a typical develop- 
ing country an increase of ten mobiles per Ioo people boosts GDP growth by 0.6 per cent. ${ }^{34}$

The whole area of mnemotechnics, the ways in which we recall, record and remember the experiences we have, is interesting. And it is my argument that such mobile technology becomes a part of our subjectivity to such an extent that it has altered the way that we define that subjectivity. I argue that we now live in a negotiated relationship with the world and with the other which is mediated through our mobile technology. Pictures are visual recollections, tapes and audio are also ways of capturing the past. However, the digital camera and video recorders in most mobile phones have resulted in an exponential increase in the number of images that have been created and printed in the last two years - the figure, and it is impossible to be accurate, of twenty billion images and videos from mobile phones has been suggested. So, the reification of the image has also been deconstructed. With my camera I can take fifty photos and delete forty-nine of them. There is a new mutability about the image and we are less keen to protect or reify the image as we can always take more. It is as if digitisation has made us less protective of the image and this also has implications for our concepts of selfhood and time. They also have implications for the way in which we act in space and time. We are now able to archive our experiences effortlessly and that means that we are far more inclined to take pictures and images of occasions. We are able to commit to our phone memory images, people, experiences and this can often shape the way in which we react. So my scopic drive is redesigned, and I see the space in which I am in both in the present moment, and as the source of an image which I can then observe. So my memories of a trip to France are now less my images of France, but images of me in France, and visual images which I can send to people on their phones. So even at a banal level, the ordeal of 'looking at my holiday snaps' has been transformed into an ongoing series of images sent from the place while I am still in that place.

34 Leonard Waverman, M. Meschi and M. Fuss, 'The impact of telecoms on economic growth in developing countries', In Africa: The Impact of Mobile Phones: Moving the Debate Forward (The Vodafone Policy Paper Series, No. 2, 2005). 
The temporal sequence of my being in a foreign country, then coming home and relaying my images to those at home is now deconstructed: I can now share my holiday snaps while still on holiday. I am able to transmit myself while mobile and my mobility and connectivity are now a core part of my subjective experience of travel - hauntologically I am in France and Ireland at the same time - a new form of spectral mobility.

In terms of self and other, the SMS service means that relationships are now altered in terms of their symbolic order. This changes much of our sense of self, and of how that is transmitted in literature. For example, the synchronous suicide of Romeo and Juliet, the isolation of Robinson Crusoe, the loneliness of Hamlet or Lear, could be ameliorated through SMS messages - a series of texts would immediately solve the problems. In fact a lot of literary dilemmas are about lack of communication and isolation and the actions that ensue from such isolation. In a contemporary context that just could not happen because we are now in immediate and embodied contact with the other through our phone. Most phones now have a vibrate function wherein there is a physical vibration of the phone to denote an incoming text message. This means that the other is able to physically affect our bodies through contact. In a real sense, we are no longer locked within our bodies as we have a somatic connection with the other through our mobile. The sensation of being alone is ours no longer. We are always contactable - even walking has changed, as the ability to walk, talk and text is now a necessary social skill. And the absent other now has the ability to touch us physically through the vibration of an SMS message - the self is hauntologically imbricated in the other and this is a fundamental change in our habitus and big Other.

Perhaps the most obvious change wrought by the mobile phone is mental and emotional connection. When my phone vibrates and I open the text, I now know, for certain, and without doubt, that someone has been thinking about me in the last $2-3$ minutes and wants to communicate with me now. That means that we are connected to the other, albeit intermittently and albeit sporadically, and this has changed the experience of being human in the third millennium. And while this connection has nothing to do with where I am, and with my location, it has everything to do with me as a person. The SMS text or the call are focused on me. 
So when I am speaking to someone, and simultaneously texting someone else, my relationships with the real and the virtual are in negotiation - and there seems to me to be a need to classify this new sense of subjectivity. The other is in connection with me and yet spectral and mobile because they are obviously somewhere else.

Two people are walking and talking in the street. At a certain point the mobile phone rings and one of the two starts talking to a third person, with all his or her gestures directed at the absent third party and not at the person next to her. In this context, where, precisely, is the person who is replying to the mobile phone? Spectrally present to the caller on the phone, is he or she not also spectrally present to the person to whom they are talking as they are not giving them their full attention? The same is true of people talking in company with friends and texting someone else at the same time. Are they fully present in actuality or in text? And this is also true even before they begin texting. Take the situation of four people talking in a group. A phone beeps or vibrates to signal an incoming text. Immediately all four people will reach for their pocket or for their bag to see if the message is for them. Immediately there is a reduction in attention to the topic of actual conversation as the prospect of a virtual conversation looms. Again, there is a spectralisation of the presence through an absent stimulus. Even the narrative imagination has to come to terms with this development. Whole films would have been impossible if there had been the mobile phone. Dr Zhivago sees Lara as she recedes into the distance. He is unable to stop her. But now the solution is easy as he can just give her a ring or send her a text. Hollywood is now taking note and basing films on this possibility. So our relationships with people become spectralised through the mobile phone and through the SMS message. We are haunted by aspects of the other. The barriers and borders between selfhood and alterity are now far more fluid and the self is more mobile in every sense of that term. As Derrida observed:

when I think negotiation, I think of this fatigue, of this without-rest, this enervating mobility preventing one from ever stopping. If you would like to translate this philosophically, the impossibility of stopping, this means: no thesis, no position, no 
theme, no station, no substance, no stability, a perpetual suspension, a suspension without rest. ${ }^{35}$

And I would argue that mobile technology is both constituent of, and a response to, this new sense of mobile subjectivity. There is no rest between presence and absence just as the spectre is unable to rest after death. But the same is true of another aspect of our mobile subjectivity and that is in our relation with space. Jameson has made the point that postmodernism is focused more on the spatial in contradistinction to modernism which is focused on the temporal.

Technology becomes part of the shaping of people and of space. For example, if my mobile phone has GPS capability, every place I go becomes a 'smart' place, inscribed in electromagnetic grids which can then be used to tell me where I am and where to go. Developed by the United States Department of Defence, GPS is officially named NAVSTAR GPS. The satellite constellation is managed by the United States Air Force soth Space Wing. The cost of maintaining the system is approximately $\$ 750$ million per year, including the replacement of aging satellites, and research and development. Following the shooting down of Korean Air Lines Flight 007 in 1983 , President Ronald Reagan issued a directive making the system available for free for civilian use as a common good. Since then, GPS has become a widely used aid to navigation worldwide, and a useful tool for map-making, land surveying, commerce, and scientific uses. GPS also provides a precise time reference used in many applications including scientific study of earthquakes, and synchronisation of telecommunications networks. A typical GPS receiver calculates its position using the signals from four or more GPS satellites. Four satellites are needed since the process needs a very accurate local time, more accurate than any normal clock can provide, so the receiver internally solves for time as well as position. In other words, the receiver uses four measurements to solve for four variables: $x, y, z$ and $t$. These values are then turned into more user-friendly forms, such as latitude/longitude or location on a map, then displayed to the user. 
Cyberspace and real space coalesce, and my current location becomes a plane of technological inscription for this global information system, and the individual human becomes a series of location zones, an evolving piece of data whose information events are fed back into this digital retention system. It is as if the world is now covered in a layer of 'virtual graffiti' to use a term coined by Howard Rheingold. ${ }^{36}$

This virtual graffiti mediates the new through the familiar - our experience of the new is always slightly fearful, and one of the best examples of this is finding one's way in a strange city. As already noted, the grids of visual graffiti mean that I no longer have to worry about finding my way through streets. I no longer have to wonder if there is a restaurant, a hotel or a shop to be found because my web browser on my mobile phone will allow me to access all of this information at the touch of a thumb - and indeed, the opposable thumb, often seen by evolutionists as the defining creature of humans as toolmakers, has now, in the third millennium, become one of our most important indices of communication - as through it we now access the world of text. Of course at another level, I have become part of the digitized web of visual graffiti because my GPS phone is emitting a signal to the satellite which can then orient me from where I am to where I want to go so I have become. So every beep of the device sends my location to the network, which then collates this information and sends me back a new destination. So my record on this planet is now being recorded on another medium. As well as my carbon footprint, there is also my digitized and triangulated footprint which is saved in various archives. So even my sense of selfhood has been changed.

Part of this change in selfhood is due to the interconnectedness between self and other and between self and place. The spatial relationship works on two levels. Firstly, as I travel through the city I leave other traces too, traces which will be incorporated into the global digital retention system. Every ATM I visit and every credit card transaction I make will be recorded. But my mobile device is a nomadic object; it literally

36 Howard Rheingold, Smart Mobs: The Next Social Revolution (New York: Perseus Publishing, 2002). 
locates me within an electronic reproduction of the territory I walk over. And it is this mobility that is the key to the negotiating powers of mobile technology. The postmodern subject can be seen as nomadic, to use Rosi Braidotti's term, and in terms of her idea of the nomadic subject, the mobile phone is a seminal.

The nomadic subject according to Braidotti's definition is 'postmodern/industrial/colonial, ${ }^{37}$ and is a subject that moves against settled and conventional ways of thinking. The nomad is one who does not suffer from compulsive displacement but travels because he or she wants to. Braidotti advocates the cultivation of a 'nomadic consciousness' which she describes as follows:

The nomadic consciousness combines coherence with mobility. It aims to rethink the unity of the subject, without reference to humanistic beliefs, without dualistic oppositions, linking instead body and mind in a new set of intensive and often intransitive transitions. ${ }^{38}$

For Braidotti, the nomadic subject is a utopian figuration that is not about displacement but about a discursive freedom from dominant narratives:

[The nomadic subject is] a figuration for the kind of subject who has relinquished all idea, desire, or nostalgia for fixity. This figuration expresses the desire for an identity made of transitions, successive shifts, and coordinated changes, without and against an essential unity. ${ }^{39}$

These changes in space have already been examined in terms of how mobile technology changes our perceptions. The same is true of my attitude to space. As I drive from Limerick to Dublin, I look at roads and streets on my GPS receiver and the images I see are almost cartoon-like images of the actual places. So rather than look at the actual space, I look at the virtual space in front of me, and my relationship with signage is also different. 
Instead of looking at a map, and waiting until I come to a specific street to take a turn, I now look at the GPS screen which tells me to turn left in 500 metres. It is important here to stress that the real is not replaced with the virtual mapping of the street; instead, the subject looks at both and negotiates between the two, now looking at the screen and now looking at the real world outside the car. The real streetscape is haunted by its two-dimensional image on the screen just as the two-dimensional image is also haunted by the real street over which and through which the car is traveling. One could see the connection as a haunting or even as a Lacanian méconnaissance, a misrecognition that is a recognition. The added fact that the GPS image of the street speaks to us makes the identification clearer. The voice of the Sat Nav will tell us that after 500 metres we should turn left, or will advise us that at the upcoming roundabout, we need to take the second exit. The more advanced systems will also tell us of traffic alerts and of hold-ups on roads. One could see the negotiation of the real and the virtual as an example of Derrida's idea of hauntology, and of how spectral mobility is now a central metaphor of how we interact with the world.

I have already discussed Derrida's ideas on hauntology, and I would argue that this haunting is part of our visual relationship with GPS (itself a technology predicated on our mobility as subjects). But it is also a significant factor in our relationships with others in terms of presence and absence as mediated by our mobile phones. One of the most common subjective experience is being lost in a strange place and one of the corollaries of being lost is the need to ask directions. However, in some of the more high-tech GPS systems, my mobile phone will tell me how to find my destination with basic instructions like next left, second exit at roundabout etc. Here, a basic human experience has been transformed by technology. In a new town or city, I can access information on tourist sites of interest through the web, and I do not need to actually talk to people. The mobile phone thus causes me to have less oral connections in reality than one might suppose. At another level, through SMS messages, oral interchange can often be interrupted by text messaging. How often do we see people having conversations at a table in a café or bar while at the same time texting someone else. Indeed text itself is a pharmakon as it has all of the immediacy and the direct access of speech while still being a kind of writing. 
As has been his wont, when Derrida looks at a new concept, he looks for a neologism to voice that concept, and in Echographies of Television, the 'portmanteau nicknames' that he outlines at the beginning of the book, 'artifactuality' and 'actuvirtuality', ${ }^{40}$ suggest how technologies create the world as much as reflect it. These two terms take in the Heideggerian connection between techné and poien, between revealing and making, and they both gesture towards the constitutive and transformative role that mobile technology has both on the subject and on the subject's negotiation with his or her world. Both terms are originally used with respect to television, with 'artifactuality' describing how public speech is produced in the maintenance of actuality. 'Actuvirtuality' suggests that with the 'actuality effect' of live television ${ }^{41}$ that the virtual has infiltrated the event to the point where the rhythm of the event, its temporality, has changed. ${ }^{42}$ Artifactuality and actuvirtuality do not attempt to 'deny' the reality of the event. Rather, they aim to deconstruct actuality in order to be attentive to what might be untimely, spectral, or specific to the event as an arrival: to remain open to 'the fact that something happens only once. ${ }^{43}$ In Echographies, Derrida grants that the technological possibility of the live changes 'our understanding of the entire field': As soon as we know, 'believe we know, or quite simply believe that the alleged 'live' or 'direct' is possible, and that voices and images can be transmitted from one side of the globe to the other, the field of perception and of experience in general is profoundly transformed. ${ }^{44}$

He suggests that these same tele-technologies accelerate the speed of democratisation, and indeed 'have done more for what is called democratization ... than all the discourses on behalf of human rights. ${ }^{45}$ So, I conclude by looking at the effect of the mobile phone on our subjectivity and, like

40 Jacques Derrida, Echographies of Television: Filmed Interviews (Cambridge: Polity Press, 2002), p. 3.

4I Derrida, Echographies of Television, p. 5 .

42 Derrida, Echographies of Television, p. 7.

43 Derrida, Echographies of Television, pp. 20-I.

44 Derrida, Echographies of Television, p. 40.

45 Derrida, Echographies of Television, p. $7 \mathrm{I}$. 
Derrida and Braidotti, will suggest that we need to redefine our subjectivity in the light of the influence of the nomadic, spectral, actuvirtual and artifactual negotiations that are created by tele-technology. And to this end I offer the formula SMS - Spectral Mobile Subject - as an apt description of how we relate to our historical context in the twenty-first century. As noted above, this signifier has the ability to stand for Spectral Mobile Subject, or Short Message Service, and I am reminded of the Vodafone advertisement where a woman is passed along a crowd like a text message. SMS captures the dimensions of the relationship between our negotiations of the real and the virtual, self and other, mobility and stasis but most of all, of the hauntings of the one by the other and the one by the all. 


\section{Globalisation, Vulnerability and the Return to Religion: Reflections from the Irish Experience}

PEADAR KIRBY

The emergence of globalisation as a central organising concept in the social sciences and beyond, while being controversial and highly contested, serves to draw attention to ways in which our established map of the social is being reshaped in fundamental ways. Among these is the role of religion in public life and the emergence of distinct horizons of progress associated with religious movements. This is the terrain that this chapter seeks to examine but it does so from a particular experience, that of Ireland. The ways in which these issues have played themselves out in the Irish experience over the past two decades could hardly be more different from that of France, for example. This is for two principal reasons. Firstly, as with so much else, modernity arrived late to Ireland but its sudden arrival has had a transformative impact, in both socio-economic and cultural terms. The period we label the Celtic Tiger, which we can roughly date from 1987 to 2007 , has reshaped the contours of Irish life in fundamental ways with the result that globalisation is widely associated in the Irish mind with what to most seems a largely positive experience of enhanced opportunity and enormous national self-esteem. The reception of the discourse of globalisation in Ireland, therefore, contrasts greatly with its more contested reception in France (as in many other parts of the world). The second difference with France relates to the crisis that has gripped the principal religious institution in Ireland, the Catholic Church, and that coincides exactly with the Celtic Tiger period. For many Irish people, this was a period of liberation from the long and firm grip the Catholic Church had on Irish life. For these two reasons, the Irish experience of globalisation and religion has been somewhat distinct and Ireland provides a particularly interesting vantage point from which to observe this topic. 
This chapter begins by examining the reception of globalisation discourse in Ireland, particularly among policy makers, drawing attention to the positive associations it has generated. The chapter then moves to a more critical reflection on globalisation, using the concept of vulnerability to account for its multifaceted social impacts. It is argued that political economy changes in the relationship of state and market worldwide (though mediated in particular ways in each society according to national political, social, economic and cultural factors) are causing an intensification and broadening of the experience of vulnerability among wide sectors of the population. The implications of this for two essential dimensions of the secular project of the French Revolution are then examined and the argument is made that this helps to explain the emergence of religion as a popular source of opposition to, and protest against, key aspects of neoliberal globalisation. There is nothing distinctively Irish about this analysis, except that it is done by an Irish scholar and begs questions about why this 'return to religion' seems less evident in today's Irish society. The final part of the chapter then turns to examine the changing role of religion in Irish life, tracing the crisis in Irish Catholicism but arguing that this may mask some more interesting changes often missed by commentators. The chapter ends by drawing some conclusions about how the analysis in the first part of the paper may offer some guidelines as to the future role of religion in Ireland.

\section{Globalisation and its Impacts}

There must be few countries in the world whose experience of globalisation is seen to be quite as positive as that of Ireland. After a century of lacklustre economic performance by comparison to most other countries in Europe, east as well as west, from the mid-1990s Ireland came to be seen as a wirtschaftswunder at a time when most of its neighbouring countries were coping with sluggish growth. Inevitably this has coloured how the 
Irish view globalisation, since Ireland's success has been attributed to its ability to avail of the new opportunities that a global economy can offer a small country. As Smith found in her study of globalisation discourse as used by Irish policy makers: 'globalisation continues to be presented in glowing terms ... as the only solution to such problems' as economic growth and social progress. ${ }^{1}$ Drawing on survey evidence, she shows that the Irish public are among the most favourably disposed to globalisation of any country in the EU-Is. She quotes the glowing accounts of globalisation offered her by senior policy makers in interviews:

In the words of one senior civil servant, globalisation has had 'a huge impact here, and it has a huge and favourable impact because we have embraced it and opened up to it.' Another described globalisation as a 'hugely powerful force here that we have turned to our advantage'. Still another declared: 'if it is globalising financial markets, globalising investment, yes please we'll have it thank you. ${ }^{2}$

In all this, Smith emphasises that such discourse is in large part independent of the 'reality' it purports to represent; it is largely a discursive construction. What is noteworthy in the Irish case is just how successful this discursive construction has been in winning public support.

This is not because the negative side effects of globalisation that cause some determined opposition in countries like France are not present in Ireland. In Ireland also, there is widespread public concern at high levels of socio-economic inequality or the growing gap between rich and poor as market liberalisation results in boosting the wealth of the best off in Irish society while making the livelihoods of the poorest more precarious. There is concern at the trend towards the privatisation of key health and education services and the growth of two-tier services as the wealthy can afford to send their children to fee-paying schools and as the public health services grow ever more ramshackle. Like elsewhere, Ireland is experiencing the inroads of the global criminal economy, with soaring gun crime linked

I Nicola Jo-Anne Smith, Showcasing Globalisation? The Political Economy of the Irish Republic (Manchester: Manchester University Press, 2005), pp. 174-5; emphasis in original.

2 Smith, Showcasing Globalisation?, p. I80; emphasis in original. 
to drug gangs and with the trafficking of women and children for the sex trade. All these manifestations of globalisation are clearly evident in Ireland but what is different is that they are not, in the public mind, linked to globalisation, which continues to be viewed in a very positive light. In this way, therefore, it can be said that the battle of ideas over globalisation has been decisively won by those who favour - and often benefit from - the liberalisation of market processes and the co-opting of the state to support and further such processes.

The impact of globalisation that is most pertinent to the concerns of this chapter is the growth in vulnerability that motivates some of the most determined opposition to it through the altermondialisation movement. As I outlined in an earlier work, ${ }^{3}$ vulnerability is the distinctive impact of globalisation on society. Vulnerability entails two dimensions: a growth in the risks or threats that people face, coupled with a weakening of their coping mechanisms to withstand these threats. As the UN put it in its 2003 report on the world's social situation, vulnerability 'exists at all levels and dimensions of society and forms an integral part of the human condition, affecting both individuals and society as a whole.' Increased threats to livelihoods and a weakening in the coping mechanisms of society, of communities and of individuals can be identified across all the principal spheres of today's world such as the financial (the sub-prime mortgage crisis and the vulnerabilities of the global financial system it has revealed), the economic (the intensification of competitiveness and the offloading of risks on to the weakest), the social (growth in inequality and the many social problems of urbanisation, crime and violence that plague people's lives, particularly those of the poorest), the environmental (global warming and the impacts of climate change), the political (the growth of counter-systemic forces, especially on the right, both within and without our political systems), the cultural (the power of the mass media to define the cultural messages

Peadar Kirby, Vulnerability and Violence: The Impact of Globalisation (London: Pluto Press, 2006).

4 United Nations, Report on the World Social Situation: Social Vulnerability: Sources and Challenges (New York: UN Department of Economic and Social Affairs, 2003). 
people receive and the intensification of a consumerist culture), and even the personal (the loss of a secure sense of belonging and a secure horizon of self-becoming). These are manifestations of what Anthony Giddens has called 'a new riskiness to risk' in today's globalised world. ${ }^{5}$ As this happens, our human and social assets are becoming more precarious - most obviously the environmental assets we have taken for granted throughout history such as clean air and water, and the predictability of climate patterns - and we are being thrown back for survival on collectivities and resources that are often themselves in a weakened or even crisis state - the family, trade unions and political parties, and even welfare states.

It is for this reason that many international political economists reach for the work of Karl Polanyi to make sense of what is happening today. For Polanyi's classic text on the British industrial revolution, The Great Transformation, is essentially about the vulnerabilities caused by the utopian attempt to make the self-regulating market the principle of social organisation. As Polanyi analyses it, this attempt to treat labour (human beings), land (the environment) and capital (money, in itself a mere medium of exchange) as marketable commodities had a highly destructive impact on society which spontaneously reacted in what Polanyi called a 'double movement' against it. He wrote that, in all eras previous to the industrial revolution, the market 'was surrounded by a number of safeguards designed to protect the prevailing organisation of society from interference on the part of market practices.' "The market has been the outcome of a conscious and often violent intervention on the part of government which imposed the market organisation on society.7 This self-regulating market treats labour, land and money as commodities and therefore leads to 'the running of society as an adjunct to the market's which 'required that the individual respect economic law even if it happened to destroy him.' This creation of

5 Quoted in Kirby, Vulnerability and Violence, p. 19.

6 Karl Polanyi, The Great Transformation (Boston: Beacon Books, 200I; Ist edn, 1944), p. 65.

7 Polanyi, The Great Transformation, p. 258.

8 Polanyi, The Great Transformation, p. 60.

9 Polanyi, The Great Transformation, p. 89. 
a 'market society' results in 'poverty amid plenty' as it inflicts 'lethal injury to the institutions in which [a person's] social existence is embodied. ${ }^{\prime 0}$ The value of Polanyi's work is that it helps identify the fundamental processes generating increased vulnerability as the market breaks loose from the restrictions imposed by the state after the world wars of the first half of the twentieth century (themselves a direct consequence of the attempt to create a 'market society' in Polanyi's view) and, now at a global level, again seeks to create a society the fundamental organising principle of which is the self-regulating market mechanism. Thus, the concept of vulnerability gets to the heart of the faultlines that divide proponents of globalisation from its critics.

\section{Challenges to the Secular Project}

Analysing the essential core of globalisation processes as the creation of a 'market society' offers a means for linking the topic of globalisation to that of religion. One phenomenon that has surprised some social scientists is the resurgence of religion as a public and indeed popular force in the new circumstances of today's global order. For example, Jürgen Habermas has recently published a book examining, according to its advertising blurb, 'an unexpected revitalization of religious traditions and the politicization of religious communities across the world, ${ }^{11}$ while a widely used reader on globalisation, now in its third edition, devotes a whole section to religion. ${ }^{12}$ The chapters in this section cover not only Islam but Pentecostalism and Catholicism also and a chapter entitled 'The Christian Revolution'

Io Polanyi, The Great Transformation, p. 164.

I Jürgen Habermas, Between Naturalism and Religion (Cambridge: Polity Press, 2008), p. 55 .

I2 Frank J. Lechner and John Boli (eds), The Globalization Reader (Oxford: Blackwell, 3 rd edn, 2008). 
concludes that 'Christianity is flourishing wonderfully among the poor and persecuted, while it atrophies among the rich and secure. ${ }^{13} \mathrm{~A}$ similar point could be made about the appeal of militant Islam, both in the Muslim world and also among the offspring of Muslim immigrants into western societies. The emergence of a political Hinduism in India and of Buddhist monks at the forefront of protest in countries like Burma and Tibet shows similar manifestations in eastern religions.

Here we have a hint of some of the reasons for religion's revitalisation in today's globalised world that refers us back to the concept of vulnerability. For the decline of religion in the West coincided with the rise of the project of state-led secular change that found a forceful articulation in the French Revolution. ${ }^{14}$ Two central dimensions of this project are of particular relevance to explain the fundamental shifts taking place - the first refers to what can be called the secular horizon of progress, based no longer upon religious beliefs of salvation or redemption but upon the secular knowledge provided by science and technology. As Gray puts it, referring to 'the authority of science': 'Modern politics has been driven by the belief that humanity can be delivered from immemorial evils by the power of knowledge. In its most radical forms this belief underpinned the experiments in revolutionary utopianism that defined the last two centuries. ${ }^{15}$ The second dimension refers to the role of the state in realising the hoped for secular progress. The vulnerabilities associated with globalisation and the creation of a market society are undermining both dimensions and thereby creating the conditions for a return to a horizon of progress based on religious worldviews. This, in essence, is the argument being advanced

I3 Philip Jenkins, 'The Christian Revolution', in The Globalization Reader, pp. 379-86, p. 385 .

I I I distinguish here the project of secular progress from the longer-term Enlightenment project on the grounds that the former entailed the secularisation and politicisation of what were central elements of the humanism engendered by the latter - the horizon of human progress, the liberation of the individual from the bonds of collectivities and the emergence of the principle of scientific rationality.

Is John Gray, Black Mass: Apocalyptic Religion and the Death of Utopia (London: Penguin, 2007), p. I4. 
here. Let us now tease out in more detail how globalisation is eroding both of these central dimensions of the secular project.

The two centuries since the French Revolution have been marked by the active propagation of a worldview hostile to religion which it saw as an obstacle to the spread of true and accurate knowledge, derived from scientific experimentation. Religion, associated with dogmatism and superstition, had to be combated and its influence minimised. Some of those motivated by a secular worldview, especially its Marxist variant, actively sought to eradicate entirely religion and its institutions while many believed it would wither of its own accord. However, an accommodation was eventually reached between the religious and secular worldview which was based on the relegation of religion to the domain of the private, where it did not act as an obstacle to the spread of progress based on scientific rationality. This is not to deny public manifestations of religion over this period, but they took place essentially within a framework of personal moral transformation that did not challenge the dominant rationality. While this clash of worldviews predated the recent emergence of globalisation as a concept, let us not forget that it coincided with the creation of a market society based on a fundamentalist belief in the operation of the free market mechanism as the only principle of efficient social organisation, a belief based on a so-called law of economics which was another expression of the scientific worldview. Furthermore, this view justified the colonial expansion of the nineteenth century, regarded by many analysts as the first era of globalisation. Polanyi saw the link clearly when he equated the impact of the Industrial Revolution on Britain's 'labouring classes' with the destruction wrought by colonialism in Africa in the early twentieth century or in India in the nineteenth century, since the expansion of the market principle did 'lethal injury to the institutions in which the [human person's] social existence is embodied. ${ }^{16}$ However, it is only in our own day that the horizon of progress based on the extension and application of scientific knowledge has come to be seen as problematic. This derives from a number of reasons but foremost among them in the contemporary consciousness are almost 
certainly the awareness of the destructive as well as the beneficial potential of science (a legacy in part of the Nazi holocaust and of the nuclear bombs of the Second World War) and the claim that the world's ecological crisis is linked to the scientific methodology of detached observation which has allowed humans treat nature as a reservoir to be exploited rather than as a web of life on which we depend and of which we are part. ${ }^{17}$ This much more ambiguous attitude towards science has found expression in Ulrich Beck's notion of a 'risk society' which faces new 'techno-hazards' such as chemical pollution, atomic radiation and genetically modified organisms that are such defining features of the spirit of today's age. ${ }^{18}$ One rather widespread and revealing expression of this ambiguity is the move to alternative medicines and healing in Western societies, based, not as in previous eras, on a suspicion of science that derived from a pre-scientific mindset, but rather on a suspicion derived from the growth of an alternative scientific mindset often closely associated with forms of spirituality. This situation has given rise to an undermining of the belief that science on its own will lead us to a better future and also to a much more problematic and uncertain attitude to the future which characterises contemporary culture (itself expressed in the postmodern, constructivist turn in the social sciences, for example).

The second dimension of the secular project that has been undermined by globalisation is the role it accorded the state as the principal vehicle for the achievement of a better future. While states remain key actors in our globalised world, the situation in which they operate presents them with new challenges and dangers due to the ways in which technologies are helping transform production and distribution. This is best appreciated by examining the erosion of the forms of state that came to dominate, particularly in the post-Second World War period, arguably the high point of the secular project of human progress. We can identify three dominant and very distinct forms of state though there were significant varieties within each of these. The first and best known to us was the welfare state, based on 1999), pp. 15-17. 
Keynesian economics and a compact between capital and labour. However, we also had the communist state that ruled much of humankind in which the state dominated the market in order to guarantee welfare benefits such as full employment, education and health care. Throughout much of what we then called the developing world, a third form of state predominated, the national development state, aspiring to develop countries through the aegis of the state. The most successful examples of this type of state were the developmental states of East Asian and a few Latin American countries. Each of these regimes was sustained by a perceived commitment on the part of the state to promote the welfare of citizens, what Rapley calls a mass perception of distributive justice, ${ }^{19}$ derived from a close link between the regime of accumulation (broadly speaking the productive economy) and a regime of distribution (broadly speaking the ways in which the state helped channel economic benefits to citizens). Focusing on this grand bargain between rulers and ruled helps identify the essence of what has changed in the nature and role of the state under the conditions of today's globalisation. For, in adjusting to the pressures presented by a more globalised economy, the state has itself become a key actor driving the process. As a consequence, and through the public action of states, 'those rules that favour global market expansion have become more robust and enforceable' (such as intellectual property rights or World Trade Organization trade dispute resolutions) while, at the same time, 'rules intended to promote equally valid social objectives, be they labour standards, human rights, environmental quality or poverty reduction, lag behind and in some instances actually have become weaker. ${ }^{20}$ This marks a decisive shift in the nature of state regulation: from a regulation that sought to harness market forces for the welfare of society to one that seeks to impose competitive disciplines on society for the good of the market. This finds expression in the many ways in which the welfare functions of the state are under pressure or, in

I9 John Rapley, Globalization and Inequality: Neoliberalism's Downward Spiral (Boulder, CO: Lynne Rienner, 2004), p. 7.

20 John Gerard Ruggie, 'Taking Embedded Liberalism Global: The Corporate Connection', in Taming Globalization: Frontiers of Governance, ed. David Held and Mathias Keonig-Archibugi (Cambridge: Polity Press, 2003), pp. 93-I29, pp. 96-7. 
some cases, have disappeared altogether (witness the unexpected collapse of the communist state) while we have the rise of what some analysts are calling the competition state ${ }^{21}$ to capture the new role the state has taken on in imposing the values and practices of competitiveness on society (including bringing them to the heart of our universities). As a result, the state has ceased to embody the central expectation that made controlling it the key objective of political struggle throughout the twentieth century, namely that it embodied the means through which to realise improved livelihoods for society (as distinct from for certain economic and political elites who control it). In this way the state has become a key driver of the creation of a market society.

The vulnerabilities unleashed by the complex forces we label globalisation are therefore eroding some of the central pillars that sustained the secular project and worldview. Without a strong belief that it provides a realisable horizon of progress and with growing disenchantment at the takeover of the state by market forces, a space is opened that may help explain the resurgence of religion to fill it. As Gray has put it: 'we have moved into a post-secular era. ${ }^{22}$ People are turning to religion (or to spirituality, as discourse in the West often prefers to call it) to find something more enduring to believe in, and a more secure sense of belonging. Often this is born of a disenchantment with secular projects (witness the replacing of the secular horizon of hope offered by Arab socialism by politicised forms of Islam) or finding in religious movements a sense of support amid difficult socio-economic conditions (the growth of evangelical sects in Latin America coincided with the worst ravages of neo-liberalism in that region). Religion, therefore, is providing responses to vulnerability alternative to the political and secular responses that were predominant over the past two centuries. It is providing a new idiom through which Polanyi's 'double movement' against the market society is finding expression. The in a Globalizing World', in Global Political Economy: Contemporary Theories, ed. Ronen Palan (London: Routledge, 2000), pp. 21-35. 
world is well aware of the dramatic and destructive idiom of certain forms of politicised Islam. But, for all their high-profile actions, these are minority expressions. Less attention has been paid to the ways in which new forms of popular education, closely linked to religious movements and church groups, have transformed political life in Latin America over the recent decade, channeling widespread discontent against neo-liberalism into new, creative and peaceful political movements for change. Religious movements and groups are also central to the altermondialisation movement and religious views inform the critique of the social inroads of the market mechanism (on the privatisation of water or the pharmaceuticalisation of health care).

This is far from a return to the religious contours of the past; instead, it marks a form of what we can call a 'religious modernity', something that to the secular mindset that dominated social sciences for much of the twentieth century would have seemed a contradiction in terms. For the revitalisation of religion today is essentially a phenomenon of popular culture, not of institutional revival. Paradoxically, certainly in Europe, it goes hand in hand with a continuing decline in religious practice, at least among Christians. It is finding expression within the idioms of contemporary individualistic and consumerist cultural forms. In a review of Charles Taylor's book A Secular Age (2007), Peter Steinfels quotes Taylor as saying that the interesting story about religion today is not simply one of decline, but also of a new placement of the sacred or spiritual in relation to individual and social life. This new placement is now the occasion for recompositions of spiritual life in new forms, and for new ways of existing both in and out of relation to God'. However, an essential feature of these recompositions is that the individual 'is now confronted with a vast range of spiritual alternatives' and often opts, in Taylor's words, for 'believing but not belonging', separating convictions from any regular practice or for a do-it-yourself bricolage, 'patching together bits and pieces from a variety of religious traditions. ${ }^{23}$ It is also therefore essentially pluralist, not mono-

23 Peter Steinfels, 'Modernity and Belief', in Commonweal, 9 May 2008, pp. I4-2I, p. 2I. 
lithic but, in a way that has not taken place for two centuries in the West, it is putting the secular worldview on the defensive. It is easy to dismiss this as a reaction to the emergence of 'Islamist terrorism', namely the use of religion to justify acts of mass murder but something more widespread seems to be at stake. As John Gray wrote about the wave of polemical anti-religious literature that has caused such controversy in Britain and the United States in recent years: ${ }^{24}$

The urgency with which they produce their anti-religious polemics suggests that a change has occurred as significant as the rise of terrorism: the tide of secularisation has turned. ... The current hostility to religion is a reaction against this turnabout. Secularisation is in retreat, and the result is the appearance of an evangelical type of atheism not seen since Victorian times. ${ }^{25}$

Revealingly, the charge of fundamentalism in this instance is levelled against the atheists by their religious critics. ${ }^{26}$

\section{Religion in Contemporary Ireland}

Up to this point, it must be said, there is nothing particularly Irish about this reflection on globalisation and religion, except that it is penned by an Irish observer of these trends. We now turn to how these trends may be manifesting themselves in contemporary Ireland, a society widely regarded

24 I refer to such books as The God Delusion by Richard Dawkins, God Is Not Great by Christopher Hitchens and The End of Faith by Sam Harris, among others, that have been bestsellers in Britain and the United States.

John Gray, 'The Atheist Delusion', in The Irish Times, 20 March 2008, p. 16.

26 See the Catholic theologian John F. Haught's comment on the three books mentioned in note $2 \mathrm{I}$ above in which he writes that 'these tirades simply add to the sad spectre of global fundamentalism' (in Commonweal, 9 May 2008, p. 38 ). 
as among the most globalised in the world.$^{27}$ In religion, as in so much else, Ireland has arrived to modernity 'a little breathless and a little late.' Up to the 1980 s, it was an exception for its very high rates of religious practice (in a 1980 survey, 82 per cent of Catholics reported that they went to church at least once a week) and for the key role played by the churches, particularly the Catholic Church, in the provision of education and healthcare, giving church personnel a major influence over these spheres of public policy. Yet, even then, survey evidence was showing that rates of practice among the young were falling faster than the national average. This powerful, arrogant and domineering Catholic Church found the high point of its expression in the visit of Pope John Paul II to Ireland in September 1979, the only time a pope has visited Ireland. The scenes of mass attendance at papal events and the explicit identification of Catholicism with Irishness expressed more the legacies of the past than the realities shaping the new Ireland, though these underlying realities were little recognised at the time. Within two decades all would have changed beyond anything that could have been imagined amid the triumphalism of that moment.

While the clerical sexual scandals that came to light in the early I990s are often identified with the decline in the influence and prestige of the Irish Catholic Church, these are more the symptoms of a deeper malaise than its principal cause. Even without the clerical scandals, it is more than likely that the Church would have found it very hard to adapt to the economic

This found some evidential support in the fact that Ireland emerged as the most globalised country in the world three years in a row on the widely referenced globalisation index produced by Foreign Policy magazine - 6th place in 2001, Ist place in 2002, 2003 and 2004, 2nd place in 2005, 4th place in 2006 and 5th place in 2007. See A.T. Kearney/Foreign Policy globalization index, 'Globalization's Last Hurrah?', in Foreign Policy, January/February 2002, pp. 38-5I; 'Measuring Globalization: Economic Reversals, Forward Momentum', in Foreign Policy, March/April 2004, pp. 54-69; 'Measuring Globalization: The Global Top 20', in Foreign Policy, May/ June 2005 , pp. 52-60; 'Measuring Globalization: Who's Up, Who's Down?', in Foreign Policy, January/February 2003, pp. 60-72; 'Measuring Globalization', in Foreign Policy, January/February 2001, pp. 56-65; 'The Globalization Index', in Foreign Policy, November/December 2006, pp. 74-8I; 'The Globalization Index', in Foreign Policy, November/December 2007, pp. 68-76. 
boom and the social changes that transformed Ireland over the course of the 1990 . It is revealing that the decline of Catholicism can be said to coincide almost exactly with what we date as the Celtic Tiger period in recent Irish history: there was the prelude from 1987 to 1994 , the high point from 1994 to 2001 and the aftermath from 2001 to 2007 . Similarly, signs of crisis were beginning to become evident from the mid-1980s onwards (a serious crisis in vocations to the priesthood and religious life, accelerating decline in church practice though from a very high point, and a new willingness among political leaders to be openly critical of the church's identification with conservative lobbies); the clerical scandals emerged thick and fast during the high point of the Celtic Tiger to accelerate further the decline in church going and to erode the church's authority in severe ways; and the aftermath of the Celtic Tiger coincided with the church's attempts to put in place mechanisms to deal with the problems identified and to face up publicly to the shame and loss of face it exposed. Just as the transformation of the Irish economy and society surprised most observers over this period, similarly the swift decline of the Irish Catholic Church surprised even the most critical of observers and profoundly shocked many of its most faithful adherents.

However, the Celtic Tiger boom was not a cause of the problems; rather, it helped to expose them. The central cause is that for some decades, Irish Catholicism had been living out of a legacy that was not being renewed and updated. In other words, the very success of the Irish Catholic Church from the mid-nineteenth century to the mid-twentieth century, when it came to embody the aspirations for advancement of the Catholic (and largely nationalist in politics) people of Ireland, became its greatest weakness in a fast changing society as the Church had failed to find a new role for itself in contemporary Ireland. A key aspect of the Church fashioned in the nineteenth century was a strong culture of clericalism, as the institution became top heavy with priests and religious who kept lay people in a passive and obedient state. It was little surprise therefore that the Irish church witnessed few of the movements of lay and clerical renewal that characterised continental Catholicism in the post-war era nor that the reforming currents of the Second Vatican Council were honoured 
more in the letter than in the spirit when implemented in Ireland. ${ }^{28}$ It is no surprise also that the priesthood and religious life hold little attraction for the young in today's booming and multicultural Ireland; in 1996, fortysix men were ordained Catholic priests in Ireland but by 2007 this had dropped to nine. Since 2000, ten times more Catholic priests have died than have been ordained; in 2006 the average age of priests was sixty-three. It is rare now to see a young priest in Ireland and most of those one does see are foreigners. While surveys indicate that 44 per cent of Catholics go to church weekly, the Archbishop of Dublin, Dr Diarmuid Martin, believes the true figure is closer to half that, at least in his archdiocese. He states: 'I can go to parishes on a Sunday where I find no person in the congregations between the ages of 16 and 36. An age-filled church is not a good thing.' Priests report weekly Mass attendance in some working-class parishes to be down to 3-5 per cent while average figures for the capital are around $20-25$ per cent. ${ }^{29}$ For the first time, a vicar for evangelisation has recently been appointed in the archdiocese.

Yet, while crisis and decline seem to characterise today's Irish Catholic Church, this hides a quiet renewal that is taking place behind the public façade. The quality of liturgy and of preaching has improved immensely in recent years, if the sampling of Catholic liturgies in various parts of the country, urban and rural, by this writer is valid evidence. Having fewer priests and religious means that lay people are being brought more into ministry, and new courses established to train and form them. In these ways, a new partnership is being forged between clerical and lay members of the Irish church that is fast overcoming the clericalism of the past. New forms of devotional expression are becoming more commonplace, nurturing a new generation of Irish in ways much more suited to their needs than the devotional fare of the past. Above all, what is striking to the observer of this quiet renewal is the quality of faith and prayer that finds expres-

28 See Peadar Kirby, 'The Catholic Church in post-Celtic Tiger Ireland', in Contemporary Catholicism in Ireland: A Critical Appraisal, ed. John Littleton and Eamon Maher (Dublin: The Columba Press, 2008), pp. 25-42.

29 Patsy McGarry, 'Getting Back to Issues of Belief', in The Irish Times, I2 May 2008, p. I4. 
sion, although Archbishop Martin is correct when he says that it is largely middle class and middle aged. As he has said, the challenge now for the Irish Catholic Church is to reach out to younger people and to those who are more socio-economically and culturally marginalised in the new Ireland. This is going to be a major test of the quiet renewal taking place.

One of the big changes in Ireland's religious situation since the economic boom is the new and vibrant pluralism of religious presence and practice that has resulted. Where religion and Catholicism were largely synonymous in the Irish Republic of the past (with even the Protestant churches often occupying a very marginal position), the immigration of recent years has transformed this situation. For the first time since independence, the mainstream Protestant churches are growing as immigrants revitalise their ranks, while a number of Orthodox churches have also established themselves in Ireland for the first time. Immigrants from further afield, such as India and Africa, bring even more novel and vibrant forms of Christian liturgy and prayer that add an immense new richness to Ireland's religious experience. With 32,500 people declaring themselves to be Muslim in the 2006 census, Muslims now constitute the third largest religious group in the Republic (after Catholics and Anglicans), though this figure is widely regarded as a significant underestimation of the actual number of Muslims. All of this is challenging Irish people's long-established view of themselves as being a very religious people as the vibrancy of new forms of religious expression contrast with the often staid and formal nature of Catholic practice. Judging by recent developments, the Catholic Church seems to be accommodating itself to this new pluralist religious situation. Its decision to join the Dublin Council of Churches on the same basis as all the other member churches (most of which are tiny in size by comparison) is one signal of this; another, and more momentous one, is its welcome for proposals for more pluralist forms of school management structures; indeed, some bishops have been to the forefront in challenging the state to be more proactive on this issue. Its stance on this latter issue marks a major change from its staunch traditional defence of its control of primary and secondary schooling in Ireland.

These changes in Ireland's religious situation need to be placed in the context of the wider changes that are taking place on the island of Ireland as 
the unionist and nationalist traditions begin to collaborate in the political settlement in the North of Ireland. President McAleese reflected on the significance of this when addressing the Church of Ireland synod (the first time a President of Ireland addressed the synod) in May 2008. Referring to the opening of a tourist centre on the site of the Battle of the Boyne (in 1690 which remained a pivotal defining event for Protestants in the North of Ireland) attended by the then Taoiseach Bertie Ahern and the then Northern Ireland First Minister Revd Ian Paisley, the President said: 'That iconic symbol, the site of the Battle of the Boyne where Williamites triumphed and Jacobites were defeated, has suddenly become a symbol of a new, contemporary friendship and indeed partnership between the children of the winners and losers, all of whom are now winners in this new and generous dispensation.' She went on to speak of 'our depressing history of high unemployment and emigration, the mess of distorted relationships reaching east and west, North and South, between Catholic and Protestant, and between our island's two competing nationalisms, one Irish, the other Unionist - these things are fading into the footnotes of history' and she said that Ireland 'is now at a kind of zero hour, a moment when the direction of our next steps will fundamentally determine the trajectory of our history for generations to come (quoted in The Irish Times, Is May 2008, p. 7). Ireland is indeed at a moment of fundamental re-definitions and it is far too early to say what role religion is going to play in them.

\section{Conclusions}

One reading of the changes in Ireland's religious culture interprets the new situation as simply a catching up with the secularisation that has been taking place throughout Europe for more than two decades. Ireland may have arrived very late, but it has caught up fast. ${ }^{30}$ However, there are reasons 
to doubt that Ireland will simply imitate its neighbours and reasons to believe that the trends seen more widely afield as traced above may begin to manifest themselves in Ireland also. As globalisation heightens vulnerability and as the potential for a robust response within the contours of the secular project erodes, there is every reason to believe that the revitalisation of religion is going to continue worldwide. While the vulnerability that results from the creation of a market society has been overshadowed in Ireland amid the cacophony of economic boom, the conditions that have helped create that boom have taken Ireland very far down the road of a market society with a competition state enforcing market disciplines on society and miserably failing the most vulnerable. As economic growth recedes, these realities are already beginning to receive more attention and to impact more clearly on the life experience, especially of those on the margins of Irish society. There are many signs that this is already happening in the crisis of Ireland's health services, its underinvestment in public services, and the growing breakdown of society. In the absence of a strong socialist tradition in Irish politics, about the only institutions with any weight in Irish life that today voice a fundamental disagreement with the values and direction of Irish society are religious ones; indeed, it is striking that among the most respected prophetic public voices in Ireland today are religious figures. It is difficult to identify where a robust contestation of the shifts in power that have characterised Irish society over the past two decades can come from if not from movements and individuals in some way linked to religious motivations and worldviews. Of course, this may not happen but, if it does not, Ireland faces a grim future of greater inequality, injustice, and violence. In experiencing a revitalisation of religion as an alternative horizon of progress, as in so much else, Ireland may indeed be arriving a little breathless and a little late. Only time will tell. 



\section{The Global is Personal}

TOM INGLIS

I am standing in a supermarket aisle looking at an array of deodorants. I am perplexed. I have been told that I need to change my deodorant. I am not sure which one to choose. Would any deodorant suffice or is there one that would suit me best? I have been persuaded to think I am different. The reality, of course, is that I am like most other people in Western society: the way I see, read and understand myself and the world in which I live has been structured by discourses created and developed by institutions and organisations which have led me to this aisle, to the need to go out and buy some deodorant. ${ }^{1}$ The desire and need to buy a deodorant, like consumption itself, has been an unquestioned orthodoxy. Throughout my life, I have become consumed with the desire to consume. I am at the end of a chain of historical events that had their origins hundreds of years ago with the emergence of the modern world capitalist system. I think of myself as an individual. I have my identities and sense of self, but they have been created and developed not in conditions of my own choosing.

We have to move beyond conceptualising globalisation as a merely economic, political or social process. It is also, and perhaps above all, a cultural process and yet, the number of writers on globalisation who have explicitly focused on the cultural are quite few. To understand culture, we have to move beyond institutions such as religion, the media, sport and so forth and focus on meaning. To understand globalisation, we have to

I There are obvious connections, but also important differences, between consumer capitalism, globalisation and Westernisation. Much of this chapter concerns how the local and personal become enmeshed in global flows and, at the same time, how Western consumer practices and lifestyles are penetrating local life and personal desires. 
think of the way we see, read and understand the taken-for-granted world in which we act out our everyday lives, the meaning it has for us, the way it gives us a sense of identity and belonging. We have to think of how this unquestioned orthodoxy reaches down into our minds and bodies. ${ }^{2}$

Part of the cultural revolution of globalisation is thinking of the world as one place. We used to think of the world internationally, that is in terms of different nations and parts of the world as they relate to a particular place, for example, Ireland. Over the last fifty years, particularly after the development of photos of the earth from outer space, we have begun to see and understand the world as a whole. The recognition and acceptance of global warming is making more people aware of global interdependence and their individual moral responsibility to develop an eco-compatible lifestyle. This has brought an increase in the awareness of us being members of humankind. ${ }^{3}$ However, this sense of identity and belonging is still less strong than the sense of belonging to a nation state, ethnic group or religious community. The gap in the practices of everyday life in the West may be shrinking, but religion, language and customs still divide the world. The question is whether these cultural differences amount to a hill of beans and whether what really unites people globally is their similar lifestyles, consumption practices, desires and sense of self.

What binds people together at a global level more than anything else is consumption. The message about deodorants is part of a global cultural flow that passes over, into and through people in supermarkets, homes, schools, places of work and recreation. Strangers can share ideas and knowledge about deodorants as much as they can about football, films and music. This cultural revolution, this constitution of the self as realised through consumption is, of course, part of a more complex matrix. It is linked to the dismantling of barriers to trade and travel, the growth of transnational

2 Appadurai argues that not only is the body at the core of consumption practices but that these practices become unquestioned, repetitious and regulated. See Arjun Appadurai, Modernity at Large: Cultural Dimensions of Globalization (Minneapolis: University of Minnesota Press, 1996), p. 67.

3 See Roland Robertson, Globalization, Social Theory and Global Culture (London: Sage, 1992), p. 58. 
companies and, in general, the way consumer capitalism reaches into minds and bodies in the remotest parts of the world. The penetrative force of consumer capitalism shrinks the importance of time and space in constituting cultural difference. It may well be that in terms of lifestyle and conceptions of the self and the world, a teenager today in a remote village in Mayo has more in common with a teenager in a remote village in Japan than she has with a teenager who lived in her village fifty years ago. The first question, then, when it comes to understanding cultural globalisation, is to what extent there is a significant difference between life in Ireland and in the rest of the West. ${ }^{4}$ The second question is to what extent similar lifestyles and patterns of production and consumption have produced a global habitus, an unquestioned orthodox way of being in the world? Have the cultural differences that come from a strong sense of bonding and belonging to a family, community, ethnic group or nation been dissipated and, consequently, is a major source of individual difference being eliminated? The third question is whether individuals can and do make a difference. In what ways, where and among whom are individuals challenging and resisting the global habitus that has emerged within consumer capitalism? Have the tentacles of global capitalism become so long and strong that they can reach down into the minds and bodies of Irish people and colonise their interests and desires to such an extent that their sense of self is increasingly realised through consumption?

The attempt to make a link between the macro and the micro, between social structures and long-term processes of social change, and the way ordinary individuals live their lives has always been central to sociology. ${ }^{5}$ There is disagreement, however, about how we go about trying to establish these links. Some concentrate on the global and the development of abstract general theories that reveal the structures and processes that are very real and have significant consequences but are not tangible or visible. And then there are those who argue that abstract generalisations

4 Tom Inglis, Global Ireland: Same Difference (New York: Routledge, 2008)

5 See Jeffrey Alexander, Bernard Giesen, Richard Münch and Neil Smelser The MicroMacro Link (Berkeley: University of California Press, 1987). 
are fictitious distortions and we should concentrate on what individuals actually do: look to where the action is. ${ }^{6}$ I believe that when it comes to understanding globalisation we need to do both. Sociology is as much an art as a science. It is about describing action and capturing meaning and, at the same time, trying to develop abstract general theories about the world. To understand globalisation we need, then, to get closer to the action, to see and understand how people live their lives locally and personally. But we also need to develop an understanding of how their lives are constituted through global structures and discourses. We need to understand the meaning of individuals' lives and how the interaction between the local and the global becomes personal.

The Irish have always been connected to the world, but what has changed dramatically is the intensity and frequency of these connections. Time and space, as Giddens puts it, have become disembedded. ${ }^{7}$ Irish people are no longer encapsulated in the time and space of the villages in which they live. The global has reached down into them. To capture this process, I will tell some personal stories that emerged from research I carried out in Ballivor, a village in County Meath. ${ }^{8}$ I will then introduce some concepts and theories that help us understand how globalisation operates and how it has influenced Irish culture, particularly in terms of how Irish people realise themselves as individuals. I will finish by looking at the extent to which individuals can make a difference in globalisation, the extent to which they can think and act outside the taken-for-granted way of being in the world that has become part and parcel of consumer capitalism. I argue that it is the ability to think and act outside of this global 'doxa' that is central to global salvation. Journal of Sociology, 86:5 (198I), pp. 984-10I4.

7 Anthony Giddens, The Consequences of Modernity (Stanford: Stanford University Press, 1990), p. 21.

8 For a more detailed description of this study, see Inglis, Global Ireland, pp. $196-248$. 


\section{Personal Stories from Ballivor}

To understand cultural globalisation operates, we have to understand how consumerism reaches into the practices and desires of individuals in the everyday lives. We have to understand how global culture becomes enmeshed in local culture and, at the same time, both are realised through consumption and, finally, how this becomes a taken-for-granted way of being into which individuals are socialised from a young age. As part my study of Ballivor, I visited the local primary school. I asked the pupils in the sixth class, generally around twelve years of age, to write an essay on 'my world' and what was meaningful and important to them in their world. This is what Joan (fictitious name) wrote:

My name is Joan. I like to horseride, play the piano, swimming and tae kwon do. My favourite programmes are Simpsons. My favourite food is curry, Irish stew, and spaghetti bolognese. My favourite thing to do on a Monday is to see my friends after the weekend. On Tuesday is tae kwon do. On Wednesday I go shopping. On Thursday I do tae kwon do. On Friday I go to scouts. On Saturday I do horseriding and on Sunday I go swimming and spend time with my family. Ballivor is a great vilage. My favourite football team is Manchester United. My favourite singer is 50 Cent (Rap singer). I like to play football with my friends in the local GAA pitch. I have i brother called Michael. I have a pet dog called Honey and a bird called Jack. My favourite DVD is A Cinderella.

Joan has many different identities, tastes and preferences. She easily mixes elements of local and global culture. She is global in her food preferences. She combines Tae Kwon Do with following Manchester United and playing gaelic football. Her tastes in music and entertainment are mostly global products. However, what is central to her lifestyle is consumption. Much of what occupies her world involves spending money.

The gradual immersion in the taken-for-granted world of producing and earning more in order to consume and spend is the story of Irish globalisation. But there was a time when it is what not possible to spend more because earning opportunities were limited. During the latter half of the twentieth century, earning opportunities in Ireland increased significantly. 
Much of this had to do with the opening up of the Irish economy and, in particular, to the arrival of transnational corporations.

In 1974, Kathleen Byrne was a married mother with three young children living in a small house in Ballivor in County Meath. Then the giant transnational corporation NEC built an enormous electronic components factory at the edge of the village. She went for an interview and was hired. Wearing a space-like suit she was trained to look through a microscope and, using a robotic arm, to put a little gold thread on a tiny micro-chip.

In the beginning Japanese operatives were brought in to train the Irish workers and the Irish workers with a good education were sent out to Japan to be trained. As more Irish operatives came up to the required level, the Japanese operatives went home. Very soon, the operatives in the factory had reached global NEC standards of productivity: they had begun to work like the rest of NEC operatives around the world. The operatives were gradually introduced into the regime of working twelve-hour shifts on a seven-days-a-week basis. It was a complete transformation of personal, family and social life. But globalisation has its rewards:

Moneywise, people began to have money because ... when it started people went into work on bicycles. There was an area for bicycles that had a cover on it but you could see after a year ... there was a few got cars, maybe old ones. But give it about seven or eight years there wasn't a bicycle to be seen. People became financially a lot more secure and you could see ... the rate of cars becoming newer and newer and newer.

Kathleen Faulkner did well. She was eventually sent out to Japan to train as a supervisor. She worked with the company for twenty-three years. She is adamant that without NEC she would not have been able to build the house in which she lives, to have her car and, most important of all for her, to send her three sons to third level education. The global flows of capital, technology and people changed Kathleen Faulkner's life as they did the lives of most people in Ireland. She, like her fellow workers, became enmeshed in the taken-for-granted world of relentlessly consumption. Leading a successful, fulsome life became conflated with acquisition. The question is to 
what extent relentless consumption reduces the importance of the local and, in particular, of the value of acquiring local cultural capital.'

\section{Bertie Cunningham}

In 1968, Bertie Cunningham was voted GAA player of the year. He had captained Meath to victory in an all-Ireland football final. There is a plaque in one of the local pubs to commemorate his achievement. And, yet, when I asked him, what was the match or victory he most remembered, he said it was the victory over Screen in an inter-county league match:

We had never had many victories over Screen. Screen would have been kingpins you know. If we ever got a victory over Screen it would be just one. If you were standing above at a Leinster final or an all-Ireland semi-final or an all-Ireland final, standing above at Croke Park and the National Anthem being played and you're standing number 6 , you're a Ballivor man first ... that's what drives you But coincidentally you are [not] just representing Meath but you're a Ballivor man first. You are representing Ballivor. You talk to any fella from any club, I would always be a Ballivor man first. and I'd be ... it would be sort of an accident I'd be playing for Meath .... .

Bertie Cunningham's world revolved around Ballivor. He was literally and metaphorically a giant of a man. When he walked down through the village, he was recognised and respected. This lasted well after NEC had come to the village. It would appear that globalisation did not undermine his status and honour. But towards the end of the r 990 os another aspect of globalisation, the inexorable growth of cities, did begin to erode his recognition and status. During the heydays of the Celtic Tiger, the population of Ballivor grew exponentially from a little under 400 to well over 1,500 . The village became surrounded with new housing developments. Most of the people who lived in these houses came from the Greater Dublin area

9 For a more detailed description and analysis of local cultural capital, see Inglis, Global Ireland, pp. 6I-8. 
and commuted back there to work. The village became swamped with what locals referred to as 'blow-ins'. Among the 'blow-ins', Bertie Cunningham was unknown.

Ten years ago, I could have brought you around every house in Ballivor and I would know everybody. You [referring to me] would be better off to go down to Ballivor on your own now because you'd know more in Ballivor than I would. ... I'd be as much a stray in Ballivor now - well I might know a few - I'd be lost.

Globalisation can be characterised in Foucault's terms as a form of microphysics, a process that reaches into all corners of the earth and which slowly, surely and subtly colonises everyday life and the way people see and understand themselves and the way they live. ${ }^{10}$ While Kathleen Faulkner and many others learned to live and work in NEC - and to prosper - Bertie Cunningham was adamant that his life and the village life of Ballivor had not been changed in any significant way by the arrival of NEC.

The personal impact of globalisation is reflected, world over, in the rise of enormous cities which, in turn, has necessitated changes in lifestyles. The workers I interviewed in Ballivor complained about the long hours they had to work, the demands of shift working, and the relentless demand to be more efficient and productive. But they considered themselves more fortunate than those who lived locally and had to commute to work in the Greater Dublin area. As one worker described it:

The pattern is to drive, they're driving from Laois up to Dublin and they're covering Ioo miles a day and that's ... and then that's not considering ....getting there early and getting home late and avoiding traffic. They're missing time with their wives. They're missing time with their children. They're putting themselves under this stress ... that you're running the risk of an accident. You're having to pay for a car the wear and tear and they say it's just not worth it.

Globalisation, then, has the effect of producing similar lifestyle practices, of working, commuting and consuming. The colonisation of desire through 
the market and the media is a fundamental part of this process. A continual flow of messages, received on a daily basis, constantly stimulate desires and create needs. The young people in Ballivor have become accustomed to adopting personal identities, to realising themselves as individuals through mixing these media and marketing messages and influences with those of the family and community in which they live.

There are many other stories that have been told about how the tentacles of globalisation have reached down into some of the most remote areas of the world. We used to think of cultural globalisation in Ireland as a form of American cultural imperialism - what may be termed the Coca-colanisation or Disneyfication of Ireland. Fintan O'Toole captured this process extremely well. ${ }^{11}$ There was a glorification and idealisation of everything American. When it came to popular culture the Irish were closer to Boston than Berlin. We adopted not just American beliefs and values, but an American disposition, a way of being and presenting oneself, a way of talking and walking, of consuming, eating and being entertained.

But it was soon realised that the notion of cultural imperialism was too strong. It suggested that Irish culture was being swamped if not drowned by American popular culture. It did not capture the way in which this American culture was being assimilated into Irish culture, nor did it say much about how many aspects of traditional Irish culture not just survived but thrived during this time. During the 1980 os, new concepts began to emerge to describe the way in which popular cultural forms developed in different parts of the world, became part of the global flow of culture which, when deposited elsewhere, became mixed with the local and national culture. And so notions of creolisation, hybridisation and mongrelisation began to be developed. These notions of cultural melting pots were important. They captured the dynamic relationship between cultures.

II Fintan O'Toole, The Ex-Isle of Erin: Images of a Global Ireland (Dublin: New Island Books, 1997). 


\section{Global Flows}

Instead, then, of seeing Ireland as being swamped by cultural imperialism or forms of Western capitalist culture, it is useful, following Appadurai, to think of it as being subject to different types of cultural global flows that sweep over the island and through people and the institutions, organisations and groups in which they are involved. The first flow concerns the movement of people in and out of the country: those who go out to learn, work, for holidays, business, education, and those who come in as tourists, immigrants, refugees, asylum seekers. ${ }^{12}$ The second flow is about the movement of technology which can be understood as the ongoing development of more rational, efficient, productive ways of mastering and controlling people and the environment. The third flow has to do with finance and pertains to the amount of money, goods, shares and services that move in, around and out of Ireland to and from centres all over the world, not just on a daily basis, but every hour and minute. The fourth flow is concerned with the reception and dissemination of knowledge, information and images of the world produced through mass media companies which own film studios, television companies, newspapers, magazines and so forth. The final flow has to do with the spread of ideas and knowledge. This flow involves debate and discussion about ways of living in the world, of organising and regulating society, and of developing the controls, freedoms and rights that are central to democracy, peace and self-fulfilment.

These flows are occurring throughout the world on a daily basis. However, they operate unevenly and inconsistently producing disjunctures within and between countries. While their impact on different societies, particularly Ireland, depends on the context and conditions in which they operate, they generally contribute towards increasing deterritorialisation in which daily life - whether it has to do with money, technology, knowledge, people or pleasure - is less and less confined to the boundaries of particular nation states, or of villages like Ballivor. And, of course, it is important 
to remember that the flow is not one way. These flows have their origins in various parts of the world, and Ireland contributes to them in various different ways. For centuries now, Irish people have migrated all over the world. Traditional Irish music has become part of world music. It is hard to find a major city in the world without an 'Irish' pub.

The concept of global flows also helps us analyse how globalisation takes place at local and national level and how, for example, some people and places are more globalised than others. The penetration of these flows, the way they are deposited and received, the way in which they were embodied and operated upon, and the way Irish people contribute to them, varies across time and space. The level of penetration depends on the amount of economic, cultural and social capital available to people and organisations. The way the flows are assimilated into Irish culture also depends on the strength and depth of existing local and national culture, the experience of globality through migration, the Irish diaspora, multinational companies, and the mass media. Embodiment also depends on the strength and depth of community, religion, family, local groups, communities and traditions. Finally, at the most micro level, it depends on the history, experience and disposition of each individual. It is not so much a question of whether hybridisation and creolisation are taking place in Ireland. It is more about questions concerning when, where, how, and among whom.

\section{The Global is Personal}

The concept of global flows helps us to analyse and describe how globalisation operates and how it reaches down into the bodies, minds and desires of people in everyday life in different parts of the world. I have argued, however, that to understand globalisation we have to step back and see how the flows are manifested in the search for identity and meaning. People are not puppets, but they realise themselves within these global flows and within structures, discourses, practices, and long-term processes of change 
that they may not always see, read or understand. The question then arises, if the global is personal, when, where and how can individuals make a difference. How can they change the force and direction of the global flows? The weak, pessimistic response is that individuals, while they like to see and think of themselves as free agents, are effectively constituted as subjects within global flows and have little or no control over them. In this version, the logic of capitalism, the market, economic growth, technology and liberal individualism are inescapable. All individuals can do is to step outside the box as much as possible and try and tell the truth about their lives. The stronger, more optimistic response is that individuals are able to challenge and resist existing orthodoxies and to change the direction of global flows. This is done through reconceptualising what it means to live a good and fulsome life, through changing the practices of everyday life and through engaging in organised opposition. But while political engagement is necessary to change the strength and direction of global flows, what is more fundamental is the development of an ethic of global responsibility which will transcend the differences between religious and secular humanistic ethics. It is necessary to go beyond the politics of the state, social class, the environment and focus on the politics of desire.

\section{Global Habitus}

There is increasing evidence of the emergence of a global culture or habitus; a shared way of seeing, understanding and being in the world that revolves around unquestioned orthodoxies, what Bourdieu calls doxa, that are embedded in most of the global flows. The questions, then, are what is this doxa? What are the institutions and discourses that structure this doxa? ? $^{13}$

I3 When Bourdieu wrote about habitus, it was often in relation to specific fields such as art, sport, religion and so forth. However, he also referred to habitus more generally 
The notion of doxa, or unquestioned orthodoxies, is central to the way fields or societies are structured. It is in the interest of the main stakeholders to maintain this doxa. Transnational corporations, nation states and state federations, organisations and alliances such as the European Union use every opportunity to promote and develop their core beliefs about the world and how we should live in it. But it is not just an ideological battle. Members of dominant elites who embody this global habitus obtain material benefits by engaging in the rhetoric, embodying the practices and, generally believing in (what Bourdieu calls) the illusio that consumer capitalism is the only game in the world. ${ }^{14}$ Through embodying this global habitus they gain access not just to economic but to other forms of capital: resources (political capital), education (cultural capital), social networks (social capital) and honour (symbolic capital). ${ }^{15}$

We need to identify and describe the hard core beliefs, the unquestioned orthodoxy or doxa that is propagated by these institutional players. These include, as already mentioned, the need for economic growth, the primacy of the marketplace, the belief that science will solve our problems, the belief in technology and that there is one best way of doing everything, the belief in the primacy of the individual and his/her happiness and, of course, the primacy of the human species. These beliefs are intricately linked into a cohesive ideology. The maintenance of the neo-liberal

as being class habitus. However, when he first applied the concept systematically it was in relation to the Kabyle in Algeria. There were ways of doing and saying things that had become ingrained in bodies, time and space. More specifically, he referred to ways of being and doing which were beyond debate or discussion as doxa. See Pierre Bourdieu, Outline of a Theory of Practice (Cambridge: Cambridge University Press, 1977), p. I68.

I4 Bourdieu uses the term illusio to refer to the uncritical acceptance not just of the rules of the 'games' we play in social life but of the games themselves. Thus, not just the rules of the capitalist market accepted uncritically but capitalism itself. See Pierre Bourdieu, 'Le Champ littéraire', in Actes de la recherche en sciences sociales 89 (1991), pp. 4-46 (pp. 22, 45).

I5 For a more detailed discussion of the different forms of capital see Pierre Bourdieu, 'The Forms of Capital', in Handbook of Theory and Research for the Sociology of Education, ed. John Richardson (New York: Greenwood Press, 1986), pp. 24I-58. 
belief in the primacy of the market is intrinsically linked to the primacy of liberal-individualism, of individuals being free to choose. The market constitutes individuals as subjects through advertising and stimulating desire. But this depends on individuals believing that the best form of society is based on individuals being, as much as possible, free to constitute themselves as individually different through the market, through strategically pursuing happiness, wealth, and well-being. To understand global habitus, then, we have to understand the way the market stimulates desire and the way this operates through the individual. If globalisation revolves around stimulating desire and people realising themselves as individuals through the market, then there is a need to become more micro in our attempt to understand social life, to come down the level of practice and the ways in which individuals realise themselves as selves, as being different. To understand globalisation we need rich thick descriptions of the meaning the market has for individuals. ${ }^{16}$ It is necessary to understand the way the market, particularly through advertising, constitutes a new sense of self. As the realisation of self through the market becomes doxa, it brings about a new more radical, rugged individual who becomes detached from communities and families and becomes more obsessed with themselves, their bodies, their smells and looks.

The dominance of transnational corporations in structuring global habitus means that, increasingly, they determine not only how to read, understand and operate in the world, but also the definitions of what constitutes the good life, what it is to be an ethical person. They stimulate desire but, at the same time, they constitute the need for people to be rational, predictable, calculable, productive and efficient. What makes the world increasingly the same is that while there are cloaks of cultural difference - and these cloaks are developing and multiplying - they are worn by bodies that have been constituted within discourses which make them the same. In other words, the cloaks of cultural difference have become thinner. The yolk of sameness, constituted through the patterns of production and consumption that structure global habitus, has become thicker. 
Things can change. People can and do resist. Kieran Allen points to signs, sites and struggles of resistance against the forces of globalisation in Ireland and around the world. ${ }^{17} \mathrm{He}$ emphasises the importance of resisting and challenging transnational corporations and states, and coming together to form an effective political grouping. But as well as challenging and resisting structures of power it is also necessary for individuals to challenge and resist existing doxa. There is a need for individuals to develop alternative truths about themselves, to change their practices, to change their lifestyles, to develop a different conception of the good life and a new form of ethics that transcends liberal individualism. ${ }^{18}$

So if we are to understand global habitus and how being in the world has become increasingly the same, we have to understand the discourse of production and consumption constituted by transnational corporations and propagated by states, the media and educational institutions. But it is not just a question of understanding the logic of transnational corporations and the ideology of neo-liberalism. Nor is it simply a question of organising against corporations and states. It is also necessary to understand the logic of liberal-individualism, the appeal and logic of the individual pursuit of pleasure and happiness. It is necessary to go beyond the macro constitutional properties of globalisation and global habitus and seek to discover how it is reproduced at the micro level, in the attempts by individuals to live a good life and realise themselves as different. It is through understanding the logic and appeal of liberal individualism that we can understand the possibility of people thinking outside the box, of

Kieran Allen, The Corporate Take Over of Ireland (Dublin: Irish Academic Press, 2007).

I8 This is what makes Bourdieu interesting. Although he wrote passionately and extensively about and against globalisation, he never undertook a comprehensive empirical study or developed a systematic theory using his own concepts of field, habitus, and forms of capital. While he described and analysed the logic of globalisation particularly in terms of the way corporations and states structured social life, he failed to describe and analyse the logic of globalisation for individuals. Pierre Bourdieu, Acts of Resistance: Against the New Myths of Our Time (Cambridge: Polity Press, 1998); Pierre Bourdieu, Firing Back: Against the Tyranny of the Marke (New York: The New Press, 2003). 
questioning and resisting the existing doxa, of telling different truths and living different ethical lives. It is this question of self-realisation and living ethical lives that most makes the global personal.

The struggle to live an ethical life is a universal feature of human society. It is only by understanding the logic of these ethical systems and the logic of the way we live our lives now, in trying to tell the truth of our times, that we can change the world. But it is fruitless and probably impossible to change the world without first changing oneself. So global change can only take place with personal change. The attempt to tell the truth about the global has to be linked to the attempt not just to tell the truth about one's self, but to live a good life.

\section{Global Ethics}

In Being and Nothingness, Sartre argued that we live in bad faith. We lie to ourselves and others about the true nature of our existence. ${ }^{19}$ There is a gap between the real truth that we know about ourselves and the image we portray to the world. We fail to live up to the truth. We portray ourselves as virtuous, as polite, honest, loyal, trustworthy and so forth, but cover up and fail to tell the truth about ourselves. Now while Sartre was referring to existential truth, what he had to say about lying to ourselves is very pertinent to the era in which we live now. The truth about globalisation is that we are living a lie about the way we are living in the world. We portray ourselves as caring and responsible and yet we are destroying the habitat in which we live and on which we depend. We continue to produce and consume more than we need. We know that present levels of production and consumption cannot go on for ever. We know that the golden rule does not apply. If everyone in the world was to live like us, there would be

19 Jean-Paul Sartre, Being and Nothingness: An Essay on Phenomological Onthology, trans. Hazel Barnes (London: Methuen, 1969), p. 329. 
no world. And, yet we want more. Our desires can never be satisfied. Until we can understand the nature of those desires, until we can tell the truth about ourselves and stop living in bad faith, we can never fully understand and resist globalisation.

One of the reasons we live in bad faith is that we do not make a connection between the global capitalism, environmental destruction and the personal. We live the lie that we can all get richer, that we can go on consuming and destroying the environment. We live the lie that science and technology will find a solution. We do not see the solution to global warming as our individual moral responsibility. We leave it to the state to develop legislation that coerces us into acting ecologically. We have not developed an ethical system which extends individual moral responsibility to include balancing the right and obligation to care for oneself, to pursue pleasure and happiness, with responsibility not just for other human beings, but other species and the environment. We do not see it as morally reprehensible for people to behave in ways that destroy the environment. We are still more obsessed with personal hygiene rather than environmental pollution. We envy travellers. We consider the well-travelled cosmopolitan who has been everywhere but belongs nowhere as more cultured than the local who stays at home. We are disgusted by prostitution but not by large cars. We honour and celebrate the rich instead of seeing them as immoral.

\section{Conclusion}

It is important in our understanding of globalisation to move beyond the orthodoxy of seeing it primarily as an economic, political and social process. It is also fundamentally a cultural one. We have to see global culture as dynamic and fluid. It is not just a case of the rest of the world becoming inexorably Western. There are flows of culture around the world which adapt to local cultural conditions. In examining these flows, it is helpful to look at how they operate not just at local level, but also in terms of 
individuals and their everyday lives. The stories of individuals in one village in Ireland help illuminate the way global cultural flows become embodied at local level. Understanding how individual tastes, preferences and desires become constituted in and through global flows, raises questions about difference, about how culture and difference has become commodified, and about how change can take place. Individual and cultural differences are becoming increasingly similar in that they are becoming embedded in the unquestioned orthodoxy and logic of consumer capitalism. It is not just culture that is becoming commodified, but desire. This, in turn, raises questions about the nature of individual difference, if individuals can and do make a difference, then how, where and among whom are people acting significantly different. Where is the resistance to consumer capitalism? It may well be that the salvation of the earth is not so much about thinking globally and acting locally, it is also about developing not so much an ethic of individual moral responsibility which has its origins in notions of individual salvation, but an ethic of global moral responsibility which is based on global environmental salvation.

This global responsibility may emerge through individuals developing a habitus, a sense of being in the world, in which instead of seeing themselves at the centre of the world, they see global being at the centre of themselves. It may well be that such an ethic can only emerge through myriads of individuals forming local organic collectivities which engage in critical reflection but develop shared rituals and practices that are oriented towards global responsibility. 
PART II

Literary Perspectives on Globalisation and Ireland 



\section{Contemporary Irish Fiction and the Transnational Imaginary}

ANNE FOGARTY

Globalisation is an increasingly vexed phenomenon, even as it has become a pervasive and ineradicable aspect of twenty-first-century existence. Prior to the economic downturn in 2009 , it had frequently been uncritically embraced by Irish social analysts and seen as a guarantor of economic advancement and a token of futurity and unfettered progress. Further, it was advocated as a panacea for insularity and a safeguard both against traditionalism and regressive tendencies to dwell on the past. Often, its impact was measured solely through economic indicators or in terms of easily quantifiable patterns of social change. The manner in which globalisation both impinged on the cultural sphere and was reflected there has until recently been largely ignored. ${ }^{1}$ In addition, the pressing ethical concerns raised by globalisation and the shifts in values that it effected have been insufficiently probed in an Irish context. ${ }^{2}$

This essay sets out to consider how debates about globalisation might be seen to inflect the work of three contemporary Irish writers. In examining Zoli by Colum McCann, The Deportees by Roddy Doyle and The Gathering by Anne Enright, my aim is not to propose that these texts perform

I Patrick Lonergan's study of Irish theatre is a pioneering investigation of this neglected topic. See Theatre and Globalization: Irish Drama in the Celtic Tiger Era (London: Palgrave Macmillan, 2009).

2 A number of recent studies, however, have begun this inquiry into ethical values and globalisation. See Tom Inglis, Global Ireland: Same Difference (London: Routledge, 2008), Peadar Kirby, Luke Gibbons and Michael Cronin, Reinventing Ireland: Culture, Society and the Global Economy (London: Pluto, 2002) and Carmen Kuhling, Cosmopolitan Ireland: Globalisation and Quality of Life (London: Pluto, 2007). 
sociological analysis under another guise or that that they conveniently yield strategic observations about a globalised, post-national Ireland. ${ }^{3}$ Indeed, as will later become evident, the burden of this essay is that, while these works may be viewed as engaging in a dialogue with current economic conditions by which they are in part shaped, their overriding concern with transnationalism is an index of the extent to which they resist and demur against the frequently ideological and normative impositions of a globalised world-view. Before proceeding to an analysis of these texts, I shall first consider the ethical and political issues that have been raised in a range of recent discussions of globalisation. Thereafter, I shall review current definitions of transnationalism and determine how they might offer an alternative vantage point to some of the restrictive isomorphisms of globalisation. As later exploration will indicate, the fiction under scrutiny in this essay is peculiarly focused on the encounter with Otherness, issues of collective responsibility and the problem of accommodating difference in multi-ethnic communities.

Anthony McGrew in his many interventions on globalisation has persistently drawn out its contradictory dynamics. In his essay 'A Global Society', he contended that globalisation leads inevitably to a conflict between homogenisation, on the one hand, and differentiation, on the other. Paradoxically, as systems of economic production and of political power become more global, the desire to establish uniqueness or difference grows. ${ }^{4}$ Even though globalisation is commonly assumed to have a levelling effect, it also produces multiple locations and platforms (especially through the auspices of the media and communications technology) that permit the proliferation and expansion of notions of difference. Globalisation, for McGrew, replaces a single economic system with an array of centres. Decentralisation The Deportees (London: Jonathan Cape, 2007) and Anne Enright, The Gathering (London: Jonathan Cape, 2007). All further references will be to these editions and will be noted in parentheses.

4 Anthony McGrew, 'A Global Society', in Modernity and Its Futures, ed. Stuart Hall, David Held and Tony McGrew (London: Polity Press in association with the Open University, 2002), pp. 6I-IO2. 
is a necessary accompaniment to, and corollary of, centralisation. In the preface to a recent collection of essays, McGrew and David Held reflected further on the divisive debates surrounding the notion of globalisation. ${ }^{5}$ They noted that arguments about the varying normative and ethical stances which it presupposes preoccupy its advocates as much as its detractors. Moreover, they declared that critical and evaluative judgements about the tendencies and consequences of globalisation are perforce an aspect of any analysis of this phenomenon. They pertinently argued that critics falsely see this transformation of contemporary economies as a single hegemonic political project, whether this is construed as neo-liberalism or Westernisation. Instead, they claimed that it is more accurate to see the world as divided between clashing forms of globalisation. Further, they observed that there is no simple correlation between political beliefs, such as left and right, and attitudes towards globalisation. However, drawing on the ideas of Simon Tormey, they ultimately concluded that the most important split in appraisals of globalisation is between what they dub 'ideological' and 'post-ideological' positions: those who judge it in relation to how far it advances or constrains progress towards a particular ideal or social goal and those who assess it on the basis of how far it facilitates or hinders pluralism or diversity. ${ }^{6}$ In the one view, globalisation is to be embraced because it furthers universal values, while the counter-view holds that it should be critiqued and resisted due to its erasure of difference and inability to countenance multiplicity.

This essay will draw on the ideas and propositions of the latter group. Saskia Sassen, for example, has recently argued that the global may be seen as simultaneously transcending the exclusive boundaries of nation states while also partly inhabiting national territories. ${ }^{7}$ She contended that it is vital to retain and critically examine notions of the local and the sub-

5 David Held and Anthony McGrew, 'Introduction: Globalization at Risk?', in Globalization Theory: Approaches and Controversies, edited by David Held and Anthony McGrew (Cambridge: Polity Press, 2007), pp. I-II.

6 Simon Tormey, Anti-Capitalism: A Beginner's Guide (Oxford: Oneworld, 2004).

7 Saskia Sassen, 'The Places and Spaces of the Global: An Expanded Analytic Terrain', in Globalization Theory: Approaches and Controversies, pp. 79-105. 
national as both of these can be sites for the multi-scalar and denationalised workings of globalisation. Further, she pointed out that localities can operate horizontally across borders and, as a consequence, it is erroneous to conceive of the global as a mere scaling upwards of things. Sassen's interventions may usefully be linked with Arjun Appadurai's contiguous account of the concept of locality in his much-cited study, Modernity at Large. ${ }^{8}$ In this volume, he defined this term as primarily relational and contextual, rather than scalar or spatial. He summed up his views by defining locality 'as a complex phenomenological quality, constituted by a series of links between the sense of social immediacy, the technologies of interactivity, and the relativity of contexts. ${ }^{\prime 9}$ He contrasted this notion of locality with that of the neighbourhood which he described as a situated community characterised by actuality, whether spatial or virtual. Appadurai, whose primary interest lies in the field of ethno-geography, further argued that all investigations of neighbourhoods or communities reveal their fragility and precariousness. The locality in a similar manner must be seen as contingent, vulnerable, and subject to constant change and negotiation.

John Tomlinson has also reflected on the crucial concept of the local which is a pendant to and shadow-development of the global. ${ }^{10} \mathrm{He}$ averred that the deterritorialisation that is linked with the increased connectivity and proliferating forms of communication made possible by globalisation does not lead inevitably to a loss of local distinctiveness. However, in a world contoured by numerous possible webs of exchange, it is the case that location is increasingly penetrated or suffused by distance. More and more we live simultaneously at a fixed address while inhabiting multiple, virtual, connected and phantasmagoric sites. Tomlinson claimed what he termed the 'telemediatisation' of communication has created a culture of immediacy. He also considered how the new cultural practices and spaces of global modernity have lead to an intersection of the political and the (Minneapolis: University of Minnesota Press, 1996).

9 Appadurai, Modernity at Large, p. 204.

Io John Tomlinson, 'Globalization and Cultural Analysis', in Globalization Theory: Approaches and Controversies, pp. I48-68. 
ethical. He revisited Jacques Derrida's findings in On Cosmopolitanism and Forgiveness that a cluster of quasi-religious notions and rituals - forgiveness, repentance, confession and apology - have now found general application in cross-cultural acts of public, institutional contrition. Like Derrida, Tomlinson concluded that globalisation permitted the working out and adoption of a universal, cosmopolitan ethics.

While the theories and arguments reviewed hitherto in this essay suggest that difference is a key aspect of the global, rival viewpoints have been put forward by those who declare allegiance to a philosophy of transnationalism. The feminist critic, Inderpal Grewal, in her exploration of Asian writing in English has explored how the transnational may be posited as being in opposition to the global and the universal while also intersecting with them. ${ }^{11}$ Whereas the global is frequently defined in accordance with a homogeneous set of criteria, the transnation designates spaces and practices peculiar to border-crossing agents who can be either dominant or marginal. ${ }^{12}$ Globalisation assumes a universal core and produces a hierarchy of subjects. The transnation, by contrast, can be conceived of as a space of exchange and participation in which processes of hybridisation occur and in which it is still possible for cultures to be performed without mediation by the centre. Transnationalism, as it has been formulated by its proponents, is directed from above and below; it is both an aspect of globalisation but may also be resistant to it. The transnational is not bound by the binary opposition of the centre and the margin and can occur in a variety of spaces, national, local or global.

Colum McCann's Zoli grapples with the politics of such an aesthetic of the transnational. The novel freely adapts the biography of the Romani poet,

II Inderpal Grewal, Transnational America: Feminisms, Diasporas, Neoliberalisms (Durham: Duke University Press, 2005).

I2 For debates about this notion, see Minor Transnationalism, ed. Françoise Lionnet and Shu-mei Shih (Durham: Duke University Press, 2005), pp. 2-23, and The Transnational Studies Reader: Intersections and Innovations, edited by Sanjeev Khagram and Peggy Levitt (London: Routledge, 2008), pp. I-I8. 
Bronislawa Wajs, who was commonly known as Papusza. ${ }^{13}$ McCann borrows aspects of her history, but alters many others. Crucially, he artificially extends her life to the present and also makes her even more nomadic and elusive than she was in actuality. In his hands, she becomes symbolic of the hybridity of contemporary life, while also acting as a reminder of the wager and costs of identity and belonging and as a cipher for the buried atrocities of twentieth-century European history. At the beginning of the novel, Zoli's family is murdered by Slovakian fascists. She is raised by her grandfather who teaches her, contrary to custom, how to write and furthers her accomplishments as a singer and performer of oral poetry. Under communism, she is briefly celebrated as an embodiment of the socialist spirit and designated a voice of the people. Thereafter, she is doubly persecuted, as under the terms of the so-called 'Great Halt', Romani communities are forced to settle. She is also turned into an outcast by her own people and ostracised because they see the publication of poems as an act of betrayal, since it broadcasts what should remain secret. Unlike the historical poet who died in obscurity in southern Poland, McCann's heroine escapes to a new Europe, becomes a refugee after the Second World War and a displaced person in Austria. She later migrates to northern Italy where she marries and raises a child.

McCann refashions history without appropriating Papusza's voice. Zoli is a vivid presence in the novel which is focalised in part from her point of view. But the author does not commandeer her story. This is particularly evident in the fact that he rarely quotes her poems directly. The competing frames and perspectives in the novel which are juxtaposed and partly overlaid raise questions about the validity of cultural assimilation and about the limits of empathy. Stephen Swann, Zoli's lover, tells his story, while we are also privy to the fumbling viewpoint of David Smolenak, a

I3 Bronislawa Wajs (1908-87) was a Romani poet and singer from Poland. She was ostracised by her community for publishing her work and as a consequence she ceased to write and spent the last decades of her life in isolation. For details of her biography, see Isabel Fonseca, Bury Me Standing: The Gypsies and Their Journey (London: Chatto and Windus, 1995). 
Slovakian journalist who is trying to track Zoli, piece her history together and set her up as an icon of Romani culture.

At one point in the novel, Zoli pleads with her publisher, Swann, to retract her work. He refuses as he cannot disappoint the authorities. But he suddenly has an insight into her plight:

She was absolutely real to me then, no longer the Gypsy poet, the ideal Citizen, the new Soviet woman, something exotic to fall in love with. I understood what Stránksy had understood too late - we had interrupted her solitude in order to compensate for our own. (p. 107)

Despite his protests here, Swann in effect persistently turns Zoli into a symbol to suit his needs. The view of Zoli as the quintessence of solitude is a Romantic projection that bypasses her and ignores her actual dilemmas. She is seen in this manner by all of the men in the novel and turned into an embodiment of absolute difference. By contrast, Zoli herself expresses an alternative philosophy. She explains that she had intended her voice to explicate Otherness, 'to pierce the difference between stars and ceilings' (p. I20). However, she also recognises that Otherness gets reinscribed by those in authority and obliterated or used for ideological ends: 'I had sold my voice $[. .$.$] to the arguments of power' (p. 125).$

As Zoli metamorphoses from pariah to refugee and from nomad to asylum seeker, she tries to elude the categories that are used to control and define her. Her migrant existence as she moves from Communist Slovakia and Hungary to Austria and then to Italy also allows McCann to demonstrate how national borders act as systems of exclusion. Yet they also can be reconfigured by his transnational heroine who remakes her identity while retaining its kernel as she moves along. In a reminiscence late in the novel, Zoli reflects on how Romani culture is a shibboleth, an invention by those who have persecuted her people:

I am filled with the memory of those who have lived and died. We have our fools and evils, chonorroeja, but we are pulled together by the hatred of those who surround us. Show me a single patch of land we did not leave, or would not leave, a single place we have not turned from. And while I cursed so many of my own, our sleight of hand, our twin tongues, my own vain stupidities, even the worst of us has 
never been among the worst of them. They make enemies of us so that they do not have to look at themselves. (p. 198)

Through Zoli's self-narration, McCann constructs an indictment of societies that are intolerant of difference and create Others in order to shore up their corrupt regimes. However, he also shows that such racism and suspect manipulation of cultures that are branded as different or exotic are not just facets of the European past. The novel ends in the present in Paris, where Zoli attends a conference about Romani culture, organised by her daughter. After some delay, she evades even this sympathetic academic scrutiny and runs away, observing that 'nothing can ever be arrived at' (p. 272). McCann's restless heroine remains a nomadic, border-crossing subject until the end. She eludes all of the frameworks, fictional and epistemological, that we might apply to decipher her. The novel thus implicitly turns a lens on the ethics of global narratives, the forms of engagement that they encourage and the means they deploy in order to elicit their themes. McCann's transnational heroine is hence in part deployed in order to critique the universalising aspirations of a globalised world and to question the false intimacies that it produces.

Roddy Doyle in the brief preface to The Deportees comments that the recent emergence of a multi-ethnic Irish society retroactively altered his earlier fictions and put pressure on their premises and assumptions. He notes that the line in The Commitments that the 'Irish are the niggers of Europe' has become meaningless now. The presence of so many immigrants from African countries in Ireland today renders such a quip impossible. By implication he suggests that local self-understanding must also be rethought. The stories in The Deportees were composed for Metro Eireann and written in short, weekly installments. They are indicative of Doyle's willingness to experiment with form and to seek and create new audiences, in this case the largely immigrant but partly Irish readership of this free newspaper. Further, the stories may be deemed to embody the immediacy and instantaneity of global culture. However, despite this accessibility and commodification, they reflect seriously and darkly on the themes of distance and the existence of a virulent and endemic racism in Irish society. In the tales, Doyle intertwines the theme of the encounter with 
Otherness and that of prejudice. His characters learn to open themselves in limited ways to those they initially view as outsiders and Others while they also are forced to recognise their own innate tendency towards racist bias. Thus, Larry Linnane in 'Guess Who's Coming for the Dinner' has to reflect on his conflicted feelings and attitudes when his daughter brings home a Nigerian friend whom he thinks is her boyfriend:

He wasn't a racist. He was sure about that now, positive - he thought. When he watched a footballer, for example, he didn't see skin: he saw skill. Paul McGrath, black and brilliant. Gary Breen, white and shite. And it was the same with music. Phil Lynott, absolutely brilliant. Neil Diamond, absolutely shite. And politics. Mandela, a hero. Ahern, a chancer

$[\ldots]$

But, why then? Why didn't he want a refugee in the family? (p. 8)

Racism depends, as many have argued, on making skin colour hypervisible, while also erasing or rendering invisible the presence of ethnic outsiders or migrants within a society. Doyle deliberately exposes these repressive mechanisms by concentrating on moments of looking, exchanged glances and what Emmanuel Levinas calls the face-to-face encounter. Larry feels exposed when he first meets Ben: 'Larry could feel himself shaking. His face was burning. He could feel his heart kicking the blood straight to his cheeks and armpits' (p. 16). Equally, Ben, the Nigerian guest, feels vulnerable as the family scrutinises his reactions: 'He saw that they were looking at him and his mouth opened slightly, and stayed that way for what seemed like hours. It was like he'd become a photograph of himself, his copied eyes fixed on Larry' (p. 22). Through such scenes of mutual viewing, Doyle both explores the painful condition of being cast as an outsider and the grudging and piecemeal adjustment that is made by white Irish culture even as it attempts to embrace Otherness.

In a similar vein, in 'The Deportees', Jimmy Rabbitte's plan to form a new multi-ethnic group forces him initially to racialise the Irish - he toys with inserting the proviso in the advert, 'white Irish need not apply' (p. 36) - as well as to confront his own racism. As in the other tales, Doyle stresses moments of mutual painful encounter. When Rabbitte initially 
meets King Robert, the first African singer whom he signs up for the band, they simultaneously discomfit each other:

Jimmy ordered the pint from the Latvian-looking barman who'd joined the Portuguese-looking one. The place was getting busy, beginning to nicely hop. Jimmy turned back to King Robert.

- Your English is very good, by the way.

- As is yours, Mister Rabbitte. You speak it like a native.

And now Jimmy stared at him. (p. 40)

Here it is Jimmy who has to adjust his vision, but he does so ironically by staring fetishistically at King Robert all the more.

Ultimately, the tenor of these stories is reconciliatory. For Doyle, ethical issues such as trust, responsibility and shared moral values allow a rapprochement between his northside Dubliners and the new immigrants in their city to occur. However, he has been accused of ethnocentrism and of supporting a questionably integrationist model of multiculturalism. ${ }^{14}$ Such a critique is, however, refuted by those stories that envisage the viewpoint of the Other without falsely trying to fuse it with, or assimilate it to, an Irish perspective. 'New Boy' tells the story of Joseph and his attempts to understand Irish culture during his first day at school. He is picked upon by the class bully. In representing Joseph's internal monologue, Doyle creates a cross-cultural perspective which defamiliarises and questions aspects of Irish life:

What did Christian Kelly mean? You are dead. Joseph thinks about these words and this too is not difficult. It is very clear that Joseph is not dead. So, Christian Kelly's words must refer to the future. You will be dead. All boys must grow and eventually die - Joseph knows this; he has seen dead men and boys. Christian Kelly's words are clearly intended as a threat, or a promise. I will kill you. But Christian Kelly will not murder Joseph just because the girl with the magnified eyes smiled at him. I will burt you. This is what Christian Kelly means. (p. 82)

I4 Maureen Reddy, 'Reading and Writing Race in Ireland: Roddy Doyle and Metro Eireann', in Irish University Review 35:2 (2005), pp. 374-88. 
Joseph's struggle with the racist, bullying school boys is interwoven with his memories of his father's brutal murder in an unspecified country in Africa. A moment of solidarity between the boys at the end of the story permits Joseph, however, to recover a happy memory of his father. Doyle's narrative technique makes us aware of distance as well as the seeming cohesiveness of the new globalised community in a Dublin national school. Joseph's traumatic memories of the past are locked into the privatised, hermetic space of internal monologue and can never be integrated into the world of his Irish companions, it is suggested. They remain apart and different.

'Black Hoodie' underscores ethnic division as well as cross-cultural affinities. It is written in the idiom of a Dublin teenager who is carrying out a project testing the racism of Irish society and its dependence on stereotyping. He opens with a statement that he qualifies: 'My girlfriend is Nigerian, kind of, and when we go through shops, we're followed all the way' (p. 130). This linguistic slippage is also evident in his withholding of names. He refuses to divulge his girlfriend's name and as a result he also has to stay anonymous himself. Both protagonists hence symbolically remain nameless in this narrative about difference. At the climax of the story, the hero takes a stand against the racism of the Gardaí who arrest him. But, despite this confrontation, no closure is achieved. Uncertainty and irresolution still reign at the end as he still nervously asserts his connection with his girlfriend: 'I think I'm her fella' - but adds 'we'll see how it goes' (p. 153). Reconciliation and rapprochement, as Doyle indicates, have to be negotiated and they remain precarious and provisional.

Anne Enright's brilliantly economical and affective novel, The Gathering, likewise questions links between the global and the local and broaches a complex series of interconnected issues, including traumatic memory, collective guilt and the ethics of forgiveness. The narrative mimics many of the time-honoured features of the Irish novel and stages conventions of the family reunion, the ritualistic gathering of siblings to mark the death of a relative. The Gathering, in addition to these overt echoes, is a hybrid text, as it also conjoins a feminist story of maturation and release, a multilayered family saga, and a self-consciously symbolist postmodern fable. In bringing all of these elements together, Enright not only deftly interfuses them, but also succeeds in dislocating and altering them. One of the many 
devices of the novel is to make use of orthodox aspects of Catholicism that have apparently been outmoded in a globalised, secular Ireland. The heroine, a failed journalist but aspiring author, who is driven to nocturnal rambling and scribbling because of the death by suicide of her younger brother, Liam, is called Veronica. Enright thus overtly references the saint who in apocryphal Biblical texts helps Christ on his way to Calvary, but is ultimately a figment and invention. In traditional but fanciful iconography, she is linked with a veil or cloth bearing his face which she displays to the viewer. At one point in the narrative, the heroine muses on her feelings towards this holy predecessor:

I became quite fond of her; a figure leaning out of the crowd, both supplicatory and tender. I still think of her whenever wet towels are offered in Chinese restaurants and on old-fashioned airlines. We have lost the art of public tenderness, these small gestures of wiping and washing; we have forgotten how abjectly the body welcomes a formal touch. I knew my fate must be linked to Veronica's in some way. Perhaps I would be a photographer. Perhaps there would come a moment when I would step out of the crowd, and then return - nothing more. I thought I might become a wiper of things when I grew up: blood, tears, all of that. (pp. I28-9)

Images of skin, cloths and veils are recurrent ones in the text and become the means by which Enright envisages the Irish family which has assembled from numerous locations abroad. The trauma of the novel hinges on skin and flesh: the buried history which it slowly excavates is the molestation of Liam by Lamb Nugent, a friend of their grandmother:

He was terrified.

And before the scene became clear to me, I remember thinking, So that's what the secret is. The thing in a man's trousers - this is what it does when he is angry; it grows into the shape of a miserable child $[\ldots]$

I have seen great bleakness in Liam's eyes, on that day and on many days since but when Nugent saw me, a small girl in a school uniform holding the knob of the door, the look in his eye was one of very ordinary irritation.

'Would you ever get out of that.'

And I did. I closed the door and ran to the toilet upstairs with an urge to pee and look at the pee coming out, to poke or scratch or rub when I was finished, and smell my fingers afterwards. At least, I assume that this is what I did if I was eight years old. (p. 146) 
The memory as it is described by the protagonist is both exact, ineradicable and imprecise. Like all trauma, it is repressed but repeats itself in dislocated images and misplaced emotions throughout the narrative.

This story of an abusive primal scene at the heart of the Hegarty family in the novel is interwoven with several other plot strands. The Gathering is also a fiction about migration and the losses that are inscribed in families due to the dispersal of their members. Veronica's recollections of Liam are interspersed with a trip to Brighton to recover his body and memories of her own prior history as an emigrant in London. Liam is depicted as a Christ-like figure who absorbs the dark energies of his parents and siblings and suffers on their behalf. But he also fulfils the function of a prophet who uncovers the secrets buried in the depths of his family. His ability to disturb is additionally linked with the fact that he belongs to a lost generation of Irish emigrants that moved to Britain and never came back: 'My emigrant brother makes an old-fashioned ghost, and when he died, I dressed him in worn-out wellington boots, as the Irish seventies dipped back into the fifties in my mind' (p. 19I). His Otherness is encapsulated in these ill-assorted roles as victim, scapegoat, ungainly and passé emigrant, family goad and conscience. If Veronica produces a searing testamentary narrative due to her closeness (which verges on the erotic) with her brother, she also insists on the distance that is likewise an aspect of global narratives. Distance, in turn, is depicted as a dimension of intimacy and the familiar. The Gathering might be viewed, despite all of the competing frames that it offers us, as a fiction about locality. Its trajectories and plotlines are mapped out with precision - the middle class muddle of the family home on Griffith Way is contrasted with the dislocation of the grandmother's house in Broadstone in the north inner city. Remembered trips to St Ita's psychiatric hospital in Portrane, Donabate form a further counterpoint in the Dublin topography that is traced for us in the novel. All of these sites of trauma are in turn contrasted with the featureless, anonymous abode of the heroine. Her obsessive trips in her car at night allow her to move between and uncover the meaning of these painful localities. Her recovery of the story of her brother coincides with her retrieval of the history of her grandmother, Ada. The tale of Lamb Nugent's abuse of her brother is woven into a more complex narrative of neglect, deprivation and victimisation. Veronica's grandmother 
is shown to have been exploited and herself sexually used by Nugent; her mother is represented as exhausted and depleted by the travails of multiple births and the demands of parenting. Even Nugent, the perpetrator, is portrayed as the product of a society that twists and distorts desire. Yet, the novel while implicating all of its cast of characters in collective guilt also works its way towards forgiveness.

Fraternity and distance are aspects of the universal, cosmopolitan ethics envisaged by Jacques Derrida and Paul Ricoeur. ${ }^{15}$ Enright's narrative realises both these dimensions: her heroine gets under the skin of and incarnates her entire family, but she also skins, defamiliarises them and lays them bare, thus disclosing the Otherness that resides at the heart of the known and intimate. The novel ends fittingly in a postmodern and global space, Gatwick Airport. The final crisis experienced by Veronica permits a change of heart. Even though she has determined to run away, she at the last minute decides to return home to the precarious locality of Dublin and to the possibility of having a further child. In The Gathering, Enright reconfigures Dublin as a networked global centre and as a set of precise localities whose affective and social histories can be exactly excavated and traced. Like Veronica's cloth, the novel exposes human suffering and immerses us in it, but it also frames it and keeps it at a distance.

Luce Irigaray, akin to Derrida and Levinas, has recently propounded how the encounter with the Other might happen. For her sharing is an essential aspect of such interrelations:

We cannot share the world as it already is, with the exception of the natural world. [...] The world that we can share is always and still to be elaborated by us and between us starting from the perception and affirmation of what and who we are as human beings here and now. ${ }^{16}$

I5 See Jacques Derrida, Of Hospitality: Anne Dufourmantelle Invites Jacques Derrida to Respond, trans. Rachel Bowlby (Stanford: Stanford University Press, 2000) and Paul Ricoeur, Oneself as Another, trans. Kathleen Blamey (Chicago: University of Chicago Press, 1992). 
The novels considered in this essay are cognisant of the impact of globalisation on Irish society. They grapple with the effects of such change by probing the ethical responsibilities that this altered milieu brings with it. In looking at the notions of distance and intimacy, the meaning of locality, and staging the problematic dimensions of difference, they broach many of the ontological problems of global communities as they have been enunciated by recent social theorists. Their protagonists, moreover, conform too to notions of the transnational as they move between cultures and differing allegiances. Globalisation in these fictions is less a fait accompli than, as Irigaray argues, a shared world which has always still to be elaborated and imagined. 



\section{8. 'Root and Routes': Home and Away in Friel and Heaney}

ALISON O'MALLEY-YOUNGER AND TOM HERRON

The life of the nomad is the intermezzo.

- Gilles DELEUZE AND FÉlix GUATTARI

The notion of nation is one that has perennially obsessed scholars of Irish Studies. Such a concept is as crucial as it is contentious, addressing disputes that are political, disciplinary, constitutional, sectarian, temporal, theoretical, historiographical, oppositional, local and international. Central to the rhetoric of nation are the highly charged unifying tropes of 'place' and 'home' which sustain the hermetic interiority historically associated with the nation state. To be in and of a place is, according to philosophers such as Martin Heidegger, fundamental to a sense of authentic selfhood. Home is not merely a house, a domicile or an abode, but a powerful cultural signifier that is a point of orientation, an axis mundi that designates a sense of cultural belonging and existential shelter to the individual subject, and provides a sense of ontological surety to a cultural group. Further, as Brian Graham observes: 'place is inseparable from concepts such as empowerment, nationalism and cultural hegemony.' In short, there is a correlation between dwelling in a place and ontology which [revolves] around a profound sense of connectedness to the soil, the land, and home. This results in national identity being 'grounded' and rooted in the soil of the homeland, the heimat.

I Brian Graham, In Search of Ireland: A Cultural Geography (London: Routledge, 1997), p. xi. 
We live, as Homi Bhabha points out, in 'avowedly global times.' The boundaries between the local and the global have become amorphous, even dissolved completely due to digitisation, convergence, cyber-realities and cyber-worlds. Home no longer necessarily exists in the hic et nunc but anywhere and at any time; we are connected to a virtual virtually limitless world with an ease never before imagined which allows us to expand our borders beyond past and patria, territories and temporalities, to an inexhaustible, accelerated, international community which knows and often has no bounds. Yet, as Bhabha observes, such modes of communication simultaneously connect us to a larger world while paradoxically invading the world we recognise as ours, disturbing, 'a sense of ontology, of the essentiality or inevitability of being-and-belonging by virtue of the nation. ${ }^{3}$ Thus, while globalisation can represent a liberation from the static and putatively claustrophobic constructs associated with an 'authentic' cultural homeland, it can also represent a virtual invasion of the home ground, tradition and a sense of national or communal identity. This can lead to a sense of internal exile that leaves, according to Ien Ang, 'displaced peoples ... clinging to a primordial notion of ethnic identity ... as a secure sense of origin and belonging, and roots.'

This essay attempts to negotiate a route between static images of the global and the local by examining tropes of mobility and engaging with those in transit; the travellers, the migrants and the nomads in selected works by Brian Friel and Seamus Heaney. Underpinning our discussion will be an implicit acknowledgement of Deleuze and Guattari's notions of 'nomadism' as a subversive state which defies centres of power, and of Victor Turner's acknowledgement of the liminal state as one that is 'betwixt and between' static binarisms to suggest that for both Friel and Heaney identity is nomadic, limitless, labile and in process, as opposed to primordial, essential and fixed. In the works we discuss 'home' is sundered from Politics of Place (New York and London: Routledge, 1999), p. viii.

3 Homi Bhabha, qtd in Hamid Naficy, p. ix.

4 Ien Ang, 'On Not Speaking Chinese: Postmodern Ethnicity and the Politics of Diaspora, in New Formations, 24 (1994), pp. I-18, p. I8. 
a specific territory or place - home is always mobile: the characters are at home everywhere and nowhere, lacking any fixed ground or permanent abode.

There is a tacit critical consensus that Heaney is a poet fundamentally at home or oriented towards home; returning constantly in his imagination to the world of Mossbawn, Belaghy, Lough Neagh, County Derry, the North. But also, and more expansively, to the matter of Ireland itself; Ireland inscribed onto the land, its painful history bled into the very soil. However, we want to argue that there is also within the work an understated but insistent disturbance of such settled and grounded readings of the poetry. For within Heaney's poetry - from the earliest poems through to the most recent - there is a constant sense of restless movement, of displacement that brushes against the well-known insistence on returning to the centre, to the origin, to the omphalos. This movement, this displacement takes two predominant forms: first a restless travelling in the form of car journeys across Ireland (and beyond), and second, a deterritorialisation of the natal / primal territory itself. In Friel, also, there is a dwelling on the spirit of place as evoked in the imaginary Baile Beag ('small town' or 'small home'); a symbolic borderless locale, in which the parochial is universal and in which displacement and transitus are the norm. Invariably Friel's characters are exiles at home desiring, yet fearing, escape and making imaginary journeys to nowhere and back again. Such is the case with the protagonists of Faith Healer, all three of whom are nomads in a constant process of becoming. Faith Healer presents a ritual world of suspended reality in which the central protagonist, the 'Fantastic Francis Hardy', the faith healer of the title, dwells in the world but is not of it. With his two acolytes, Gracie (his wife or mistress) and Terry (his alcoholic stage manager), he travels around the world and between worlds, peddling his unreliable 'gift' and acting as an interface between worlds for his audience. The characters in Faith Healer are diverse, multiple, contradictory and unbounded; their worlds are transitory, liminal, nomadic, unstructured, destructured, prestructured, infinite and limitless. Their very being challenges existing social structures and definitions not from the position of another moral code, but from the process of transition itself. Thus, they move in what Deleuze 
and Guattari would define as a rhizomatic, nomadic manner: interstitial, inter-being, 'intermezzo'.

To summarise: we are proposing to read the works of Heaney and Friel, as it were rhizomatically; as texts constituting a series of movements that fly beyond what is 'known' and 'secure' towards nomadic and transitional areas of cultural negotiation between polarised opposites. The works of both writers challenge the arborescent discourses of unreconstructed nationalism that seek to subdue and vanquish nomadism: instead, they explore rhizomatic lines of flow, pregnant and indeterminate thresholds of necessary dissolution between the fixed, the finished and the predictable. We will conclude that for Heaney and Friel it is the journey and not the destination that matters, and that in a postmodern, globalised Ireland there is no such place as home.

\section{Friel's Frank Hardy: An Irish Dionysus}

In 'Five Ways of looking at Faith Healer' Nicholas Grene asserts:

One of the measures of a great work of the imagination is not just its openness to several different interpretations, but the unexplained residuum that it leaves after any and every interpretation. Faith Healer is a dramatic enactment of the fictions of memory; it is a portrait of the artist as charlatan/miracle worker; it a parable of Irish exile and return; it is a secular theatrical reading of religious rites: all true, or at least valid readings. ${ }^{5}$

Indeed, these are all ways of reading/analysing Faith Healer. There are others: it is an examination of the actor's ablation of identity in the process of performance; an allegorical depiction of the insecurity of Sinn Féin; a

5 Nicholas Grene, 'Five Ways of looking at Faith Healer', in The Cambridge Companion to Brian Friel, ed. Antony Roche (Cambridge: Cambridge University Press, 2006), p. 53 . 
shamanic quest; an example of scapegoating; the most Irish of Friel's plays; the least Irish of Friel's plays; a tragedy; a tragicomedy; a play which focuses on transcendence, determinism, place, race, and love. The fact is that there is no abstract theory or reading position that illuminates the 'core' of Faith Healer because there is no core, no centre. It is precisely because of the fact that Faith Healer is open to multiple interpretations, critically unbounded, marginal, minor and mobile that it lends itself to a textual rhizomatics a way of reading that examines aporia and interstices, nets, networks and nomadism - in which subjectivity is seen as metastable, malleable and motivated by desire.

The script of Faith Healer is comprised of a network of cross-pollinating but unstable narratives formulated by three obsessive storytellers who perform their contradictory, idiomatic monologues unable to agree on a definitive version. This is complicated by the fact that the play is constructed out of the memories and reminiscences of the three central characters, two of whom are dead. It revolves around the 'Fantastic Francis Hardy', Grace and their English stage-manager Terry, a melodramatic, alcoholic Cockney who has a 'vague sense of being associated with something ... spiritual.' ${ }^{\prime}$ The play has little discernible shape or overall logic; the protagonists have no sense of purpose or dignity and any attempt on their parts to confer significance is ineffectual and, in the final analysis fatal. There is little sense of a plot and the climax (if one exists) occurs before the play begins. Moreover, neither the play nor its characters have any conventional beginning, middle or end, existing instead as and in a perpetual limen, inextricably connected to one another in performative and performable possible worlds in which each of them plays his or her role in perpetuity; narrating and enacting their life-stories without ever reaching a satisfactory denouement or conclusion. Death is not the end for Frank and Gracie as they continue to narrate their lives after the event; but 'home' symbolises a textual death for Frank, (and one could argue, by extension for Gracie). In the moment he 'renounces chance' (p. 55) and returns to the 'homeland', when he relies

6 Brian Friel, Faith Healer (Oldcastle: Gallery Press, 1980), p. I4. All subsequent citations will be to this edition, with page numbers in brackets. 
on his unreliable gift, and forges kinship bonds with 'home', he is brutally bludgeoned to death by his countrymen. Yet, contrary to Elmer Andrews' contention that 'death is the ultimate freedom'7 for Frank Hardy, it is simply a point on a circular journey of pathological recitation, exile and return. His is a symbolic death followed by transformation and rebirth into another performance. This is yet another transgression of boundaries for a deterritorialized renegade whose strength comes from being uprooted, not rooted, and who exists, according to Gracie to 'adjust, to refashion, to re-create everything around him' (p. 25).

The characters in Faith Healer are perpetually in movement, and it is in this that we can draw parallels to Deleuze and Guattari's concept of the rhizome which has 'no beginning or end; it is always in the middle, between things ... it is alliance and conjunction which uproots the verb "to be".' Thus, the rhizome, characterised by connection and movement refuses static ontologies based on roots, successions or bloodlines. The rhizomatic is transitional, transformative, indeterminate and paradoxical. It is a 'betwixt and between' state which like Victor Turner's 'liminoid' occurs 'when the past is momentarily negated, suspended or abrogated, and the future is not yet begun, an instant of pure potentiality when everything, as it were, trembles in the balance.' Furthermore, the rhizomatic is nomadic, embracing 'homelessness' by being at home 'here and elsewhere. ${ }^{10}$ To the nomad there is no single source or site of origin, no linear path leading to and from home but, as Deleuze and Guattari argue, 'other ways of travelling and moving: proceeding from the middle, through the middle, coming and going, rather than starting and finishing. ${ }^{11}$ The nomad embodies

7 Elmer Andrews, The Art of Brian Friel: Neither Dreams Nor Reality (London: Routledge, 1995), p. 107.

8 Gilles Deleuze and Félix Guattari, $A$ Thousand Plateaus: Capitalism and Schizophrenia II, trans. B. Massumi (London: The Athlone Press, 1988), p. 24.

9 Victor Turner, From Ritual to Theatre: The Human Seriousness of Play (New York: Performing Arts Journal, 1982), p. 40.

Io Richard Kearney, Postnationalist Ireland: Politics, Culture, Philosophy (London: Routledge, 1997), p. I00.

II Deleuze and Guattari, $A$ Thousand Plateaus, p. 25. 
'becoming' rather than 'being', existence rather than essence, and in his or her rootless lifestyle $s /$ he is everywhere and nowhere at home.

Frank, Grace and Teddy are itinerant travellers, whose contradictory travelogues relay inconsistent histories of their nomadic exploits around the Celtic fringe. From time to time their stories coincide (such as the return trip to Ballybeg) but in general there is no incontrovertible, totalising narrative which propels either the play or its protagonists. Though Frank views himself as the 'artist' and Gracie and Frank as his acolytes, there is, in fact, no real sense of hierarchy between the three; nor is there between their accounts. They exist in states of nomadic becoming; schizorevolutionary holy fools, on the fringes of society, uncontained and uncontainable by rules and taboos of the arborescent structures which would seek to limit and define them.

As the play begins we meet Frank, on stage in his stained overcoat, shabby suit and stained shirt. Though ageing and jaded he immediately adopts the role of 'homo performans', reciting a litany of place names to himself and to the three rows of empty chairs on the stage:

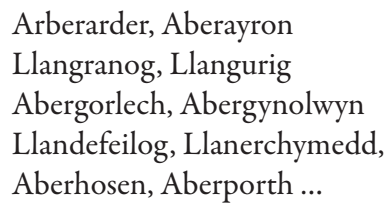

Arberarder, Aberayron

Llangranog, Llangurig

Abergorlech, Abergynolwyn

Llandefeilog, Llanerchymedd,

Aberhosen, Aberporth ...

Kinlochbervie, Inverbervie,

Inverdruie, Invergordon ... (p. I2)

This recitation is a form of self-mesmerism to sedate himself before a 'performance' of his 'unique and awesome' gift. For Grace this recital (that, she feels, not only excludes but actually obliterates her) is a 'consecration' and 'blessing' that Frank confers upon himself in order to induce the altered state of consciousness necessary for his unreliable and elusive 'magic' in which he embraces the ineffable by an ecstasy of dissolution in which his mind is displaced in an exploration of other places and beings. If we concur with this suggestion we can see Frank as shamanic, as a rhizomatic traveller not only around this world, but also a traveller between worlds; 
a wounded healer whose gift allows him to cross the threshold from the material to the non-material world, to exist temporarily out of space and time, and return into new modes of being. Frank frees himself from rationalising modes of thought by constantly transgressing boundaries. But his is not an untrammelled nomadism. His desire for a road home leads him back to the striated space of nation which to him represents a utopia of being, an answer to all the 'questionings', the 'absurd exaggerations' and the 'possibilities' which plague him. Frank desires to move from the thousand plateaus that categorise his becoming, to final destination in which he is irrevocably rooted. In effect he is self-annihilating in his desire to renounce chance. As the play ends we see Frank through his own eyes, facing what Teddy calls 'those bloody Irish Apaches' (p. 45) in the yard of the pub in Donegal. At this dangerous moment he feels, finally, at home:

And as I moved across that yard towards them and offered my self to them, then for the first time I had a simple and genuine sense of home-coming. Then for the first time there was no atrophying terror; and the maddening questions were silent.

At long last I was renouncing chance. (p. 55)

Up to this point, Frank, like Nietzsche's Zarathustra, has 'played dice with the Gods at the divine table of the earth. ${ }^{12}$ Though sometimes unwillingly he has embraced his existence and his becoming as a game of chance as opposed to one of probability and has thus remained multiple and rhizomatic. His 'gift', that he describes as 'a craft without an apprenticeship, and as a ministry without a responsibility, a vocation without a ministry (p. 13), is based on pure chance, on the throw of the dice. Even his sense of self is aleatory, based as it is on the serendipitous but random coming together of his initials: 'F.H. - Faith Healer ... perhaps if my name had been Charles Potter I would have been Cardinal Primate; or Patsy Muldoon, the fantastic Prime Minister' (p. 13). In turn, his life of chance is circumscribed by fictions in which there are no transcendent realities beyond Frank's imaginative inventions. As Gracie points out:

I2 Friedrich Nietzsche, Thus Spake Zarathustra, translated by Thomas Common (Ware: Wordsworth Editions, 1997), p. 187 
It wasn't that he was simply a liar ... it was some compulsion he had to adjust, to refashion, to re-create everything around him. Even the people who came to him they weren't just sick people who were confused and frightened and wanted to be cured; no; no to him they were ... yes, they were real enough, but not real as persons, real as fictions, his fictions, extensions of himself that came into being only because of him. (p. 25)

Like Deleuze and Guattari's 'Wasp and Orchid', each of the fictions Frank creates also creates him - they are part of his process of becoming, of transforming from 'Frank Hardy' to the 'Fantastic Frank Hardy, Faith Healer'. Thus, Frank is constituted by the very fictions he constitutes in what amounts to 'a veritable becoming, a becoming wasp of the orchid and a becoming orchid of the wasp. ${ }^{13}$ This unpredictable symbiosis alters both parties and creates something new in what amounts to a challenge to haecceity. ${ }^{14}$ Similarly, in Faith Healer nothing has any essence in and of itself - only existence as part of an interconnecting, horizontal web with each hetereogeneous element connecting to form rhizomatic structures. We only know, for example, that Frank is dead because Gracie and Teddy say that this is the case, and we are only made aware that Gracie is dead because Teddy recounts having to identify her body in a London mortuary at the end of his monologue. We have given the example above of the creative concatenation between Frank and those he heals but equally there is a fusion and connection between the three central characters that assists in their becomings. Their necessary interconnectedness is summarised by Teddy in a moment of clarity from his drunken reminiscences:

Sure they could have split. Why didn't they then? Don't ask me. For God's sake why didn't I leave them and get myself something nice and easy like - like - like a whistling dolphin? (p. 40)

I3 Deleuze and Guattari, $A$ Thousand Plateaus, p. Io.

I4 Haeccities, according to Deleuze and Guattari, 'consist entirely of relations of movement and rest between molecules and particles, capacities to affect and be affected.' A Thousand Plateaus, p. 26I. 
What is clear of all three characters is that they have no fixed or unified identities but exist relationally, in respect of and to each other. Due to the fictions they construct no given is given: instead, each character is an interwoven system of possible permutations. Yet, they exist reciprocally and symbiotically as wasp to orchid creating themselves and each other in connective synthesis. Each of them is motivated by desire: Frank for the numinous, Grace for Frank, Teddy for Grace and Frank. And as each of them is indifferent to personal identity, they are anomalous but contiguous beings who incorporate and transform the narratives which create and transform them. Grace, for example is indeterminate. She is described by Frank as 'Grace Dodsmith', his 'barren' English mistress from Yorkshire - a woman who is defined by her 'mulish, unquestioning, indefatigable loyalty' (p. I5). In her own words she is an Irish woman, educated in law, named Grace (formerly O'Dwyer) Hardy, who has suffered two miscarriages and a still birth. To Teddy she is Frank's wife but is feisty and wilful rather than perpetually downtrodden and slavishly loyal. There is no objective measure by which the truth or falsity of these statements can be measured - the interest of bias of each particular character determines the point at which the story will begin and each account is only a partial testimony. These accounts are relayed by the most unreliable of narrators whose memories are filtered through the altered states of drink, drugs and death. It evokes, as Fintan O'Toole observes, 'a suspended time and a purely theatrical space' and refuses 'to inhabit fixed categories' to foreground 'the disintegration of personality, the permeability of character, and the discontinuity between cause and effect' (p. 17). It is, as O'Toole argues, an enigmatic and circular play which generates numerous blanks and lacunae and which displays circumspection towards the arborescence of grand narratives with their implications of omniscience, completeness and integration. Equally it challenges the gravitational pull of memory as a form of arborescent tracing. Memory is radically flawed and replaced by a form of rhizomatic forgetfulness which works around modalities of interacting, connections, disjunctions and conjunctions. Instead of ratifiable memories of home, life and family the characters offer a melange of free-floating recollections which are unverifiable but connected through each character's monologue. For example Frank recalls his 'first time home in twenty years' for the death of 
his mother. He was, as he recounts it, 'in a village called Kinlochbervie, in Sutherland, about as far north as you can go in Scotland' (p. 17) when he hears the news. In Gracie's account: 'We were in Wales when he got word of his father's death. And when he came back he spoke of the death as if it had been his mother's ... And the point was his mother had been dead for years when I first met him' (p. 25). This is just one instance in which the 'truth' of the past is rendered undecipherable. Memory itself is seen as obtuse and discrepant while those who remember are unreliable in the extreme. As Seamus Heaney points out, two of them, Frank and Gracie, speak from the position of 'a kind of post-fatal depression' ${ }^{\prime 15}$ and even in this, Gracie thinks she is 'getting better.' Teddy, although still alive is inebriate and common to them all is a conflicted and traumatised relationship to the past. The status of each narrative is indeterminate and what is real (if in fact anything is), is inaccessible, relative and subjective. Because of this concepts such as 'truth' and 'falsity' cannot be employed as evaluative criteria when approaching the play. There is no incontrovertible truth in the Faith Healer, no absolute value, no Aristotelian linear progression, no Hegelian logic of cause and effect, no temporal drive. Everything in the play is fiction. There is no telos or arche; no prima facie evidence; no plot, no beginning, no end - not even a cohesive story which can be and is corroborated by all three protagonists. Instead there are multiple plateaus, shifting borders, unstable chains and lines of flight which are superficially connected, sometimes overlapping but without roots. As such it lends itself to a 'rhizomatic' reading, as Deleuze and Guattari would describe it: 'a rhizome is not amenable to any structural or generative model. ${ }^{16}$ This is equally true of Faith Healer. It is, as Nicholas Grene points out, Friel's 'most extreme experiment in dramatic minimalism. ${ }^{\text {'7 }}$ This minimalist approach is necessary to foreground the act of performance and the event of narrative. Frank, Gracie and Teddy appear on stage as both actors and characters

I6 Deleuze and Guattari, $A$ Thousand Plateaus, p. I2.

17 Grene, 'Five Ways of looking at Faith Healer', p. 62. 
simultaneously; operating in a state of double consciousness in the limens between personal identity and character realisation. This is particularly true of Frank who is constituted in the act of performance; a one man theatrical tour de force, he lives and dies and lives again to entertain; an unruly body who is perpetually becoming something else and ceasing to be in his finale - his denouement is his demise as it represents stasis and the end of his restless, liminal nomadism.

As Rosi Braidotti points out: 'the nomadic style is about transitions and passages without predetermined destinations or lost homelands. ${ }^{18}$ However, for Frank Hardy, according to Seamus Deane, 'the ultimate test of his gift is home.' ${ }^{19}$ 'Ballybeg' as Deane observes, is 'unavoidable.' ${ }^{20}$ It is also chimerical - the homeland which Frank feels will 'recharge' and 'restore' him (p.30) is a fiction. In his yearning for home, Frank moves from being a nomad, 'the kind of subject who has relinquished all idea, desire, or nostalgia for fixity ${ }^{21}$ to an exile - uprooted, homesick and yearning for a point of destination that is a heterotopia - an idea that can never be realised because it isn't real. It is the journey that matters: hence the correspondence in all three accounts of the journey home:

The last day of August we crossed from Stranraer to Larne and drove through the night to County Donegal. And there we got lodgings in a pub, a lounge bar, really, outside a village called Ballybeg, not far from Donegal Town. ${ }^{22}$

Up to this point, the characters' memories have followed forking paths - incommensurable but connected but here they coalesce not so much around Ballybeg but on the passage home. From this point, the accounts of Frank's violent death differ and Ballybeg becomes intangible, permeable and shifting in their recollections. For Grace and Teddy the place recedes

Rosi Braidotti, Nomadic Subjects (New York: Columbia University Press, 1994), p. 25 .

I9 Seamus Deane, in The Achievement of Brian Friel, ed. Alan Peacock (Gerrards Cross: Colin Smythe, 1993), p. IIo.

20 Deane, in Peacock, The Achievement of Brian Friel, p. III.

2I Braidotti, Nomadic Subjects, p. 22.

22 Brian Friel, Faith Healer (Oldcastle: Gallery Press, 1980), p. I6. 
and becomes a setting for the nauseating violence of Frank's death. For Frank it is the axis mundi to which he has gravitated; the place where, as Ulf Dantanus suggests, 'he has found his final identity.' It is here in Ballybeg that Frank, in embracing the certainty of his death at the hands of the wedding guests 'renounces chance.' In this moment of achieving his goal or telos Frank chooses being over becoming, essence over existence(s), roots over routes, and in the finitude of actualisation his meets his end.

It is easy to make a case that Frank experiences a monstrous epiphany amongst the ecstatic revellers on a night he describes as 'frenzied', 'Dionysian' and 'Bacchanalian' ( $p$. 19). If we follow this argument we can suggest that Frank becomes Dionysian and, as Nietzsche comments in The Birth of Tragedy, 'experiencing in himself the agonies of individuation ... [is] torn to pieces by the Titans. ${ }^{24}$ It would follow that in this final ecstasy of dissolution Frank's self-annihilation is heroic - and in a Dionysian sense it is. But this is not, as Nicholas Grene suggests, 'the formal closure of tragedy. ${ }^{25}$ Instead, it is the moment in which Frank experiences a becoming-Dionysian; a moment of enthousiasmos in which he takes on the duality, paradox, illusion, enigma and rhizomatic characteristics of the twice-born god.

As Deleuze and Guattari argue: 'a rhizome may be broken, shattered at a given spot, but it will start up again on one of its old lines, or on new lines. ${ }^{26}$ This could be a description of the Dionysian. Dionysus is associated with masks, role play and loss or change of identity. After his moment of sparagmos he is reborn, as Nietzsche points out: 'Dionysus cut to pieces is a promise of life: it will return again from destruction. ${ }^{27}$ Equally, Frank's onstage death does not mean his end, just the end of this particular performance prior to the curtain rising on the next, where he will continue always to be adrift - privileging the journey over the arrival in a perpetual cycle of the being of becoming. Like Dionysus Frank Hardy is both pharmakos

23 Ulf Dantanus, Brian Friel: A Study (London: Faber, 1988), p. 176.

24 Friedrich Nietzsche, The Will to Power, trans. W. Kaufmann and R.H. Hollingdale (New York: Vintage Books, 1968), p. 73.

25 Grene, 'Five ways of looking at Faith Healer', p. 62.

26 Deleuze and Guattari, $A$ Thousand Plateaus, p. 9.

27 Nietzsche, The Will to Power, p. 543. 
and pharmakeus - scapegoat and sorcerer - a being who exists in indefinite flux, a dissolver of boundaries and purveyor of paradox for whom home is an open-ended [endpoint] of rhizomatic transformation rather than an aborescent root of identity and origin. Thus, for Frank, as for many of Friel's characters, 'home' is neither a goal nor a memory - a place of pilgrimage or exile - but always indefinite, in flux, out of reach.

\section{Seamus Heaney: The Poet Unhoming}

So entrenched is the line of thought that links Seamus Heaney to notions of 'home' - be they the intimate spaces of his County Derry childhood (Death of a Naturalist); or the expanded horizons in which the homeground is conceived as a historiography of colonial usurpation and anti-colonial resistance (Wintering Out); or the feminised and eroticised terrain on which he founds his archetype of sacrifice to Mother Earth (North) - that it may seem absurd to suggest a reading of his work oriented as much to nomadic lines of flight across fleetingly glimpsed territory as to laborious excavations of the 'galleried earth. ${ }^{28}$ Although in recent years there has been a loosening of the critical orthodoxy that had him stuck in the bog and in his father's scraggy acres, there are still few critical commentaries on his work that do not adhere, with varying degrees of insistence, to the notion of Heaney as the most grounded of poets: grounded in the land, in its archaeological properties and mythological potentialities; and grounded in the roots and resonances of language, the etymology and the lore of place names (dinnseanchas). Thomas Docherty suggests that the attention critics have paid to Heaney's relationship to the land is part of a more general positioning of him as 'a late Modernist poet, the ephebe influenced by Yeats and by a Romantic tradition which was crucially concerned with landscape and a particular kind of eco-relation to the

28 Seamus Heaney, 'District and Circle', District and Circle (London: Faber, 2006), p. 2I. 
land. ${ }^{29}$ David Lloyd goes further when he accuses Heaney of replaying the Romantic schema of a return to origins which restores continuity through fuller self-possession, and accordingly rehearses the compensations conducted by Irish Romantic nationalism. ${ }^{30}$ Contrasting Heaney's 'treatment of origins' with those of Paul Muldoon, Sean O’Brien writes:

If Heaney's poems return often to the theme of having somewhere to come from, Muldoon's have a much more unstable, complex sense of the past and of identity. Heaney often earths himself imaginatively in the family farm and its surroundings, while Muldoon's home ground is always already an elsewhere. ${ }^{31}$

In a more general sense as well, Heaney's poetry has often been praised by critics for its truth-value, its fidelity to the natural world, its production or uncovering of truths subtending what were, for such a long period of time, the monotonous and largely bankrupt rhetoric of what has passed for political discourse in, and relating to, the North of Ireland. These are attributes that Heaney himself has not been coy to encourage. In his 1995 Nobel Lecture, for example, he announced that he credited poetry:

ultimately because [it] can make an order ... true to the impact of external reality and ... sensitive to the inner laws of the poet's being ... An order where we can at last grow up to that which we stored up as we grew. An order which satisfies all that is appetitive in the intelligence and prehensile in the affections. I credit poetry, in other words, both for being itself and for being a help, for making possible a fluid and restorative relationship between the mind's centre and its circumference ... I credit it because credit is due to it, in our time and in all time, for its truth to life, in every sense of that phrase. ${ }^{32}$

29 Thomas Docherty, 'Ana-; or Postmodernism, Landscape, Seamus Heaney', in Contemporary Poetry Meets Modern Theory, ed. Anthony Easthope and J.O. Thompson (London: Routledge, 1991), p. 69.

30 David Lloyd, Anomalous States: Irish Writing and the Post-Colonial Moment (Dublin: The Lilliput Press, 1993), p. 20.

3I Sean O'Brien, The Deregulated Muse (Newcastle upon Tyne: Bloodaxe Books, 1998), p. 173.

32 Seamus Heaney, Opened Ground: Poems, 1966-19g6 (London: Faber, 1988), p. 448. 
We are not suggesting that Heaney's poetry is uninterested in place. Instead, we wish to argue that there are other powerful strains within the poetry that would trouble readings that characterise Heaney as exclusively or even predominantly a poet of numinous, centred place - of the well, of the tree, of the omphalos, the source, the bog. Although there are indeed elements of the poetry that might seem to typify all too compliantly Heidegger's vision of the conditions whereby modern man may 'dwell poetically', there is also within the work an unstated but insistent disturbance of such settled and grounded notions of being. Seamus Deane detected as much when, in 1991, he noted in Heaney's more recent work 'a turn from place to time, from a past ... to a mobile future that refuses localism. ${ }^{33} \mathrm{We}$ want to suggest that far from returning to a securely known homeground, Heaney's poetry disavows the nostalgic certitude that follows from the backward look. 'Home' in the work is constantly renewed, reimagined, relocated, made strange and different to 'itself', so that, like Muldoon, Heaney's homeground is 'always already an elsewhere'.

Let's begin with the first mode of displacement: the journey by car. Medbh McGuckian has noted the ubiquity of cars and the prevalence of car journeys in Heaney's poetry: 'for Seamus', she argues, 'the car is not so much an occasionally suitable vehicle for poetic statement as a fifth element. ${ }^{34}$ And true enough, car journeys are everywhere: through 'Montreuil, Abbeville, Beauvais,, ${ }^{35}$ across 'Jutland', ${ }^{36}$ through Tuscany and 'the green / oak-valleys of Dordogne, ${ }^{37}$ 'into the burning valley of Gijon' and along 'the hellish roads, ${ }^{38}$ across the 'high bare roads of the pays basque, ${ }^{39}$ 'at

Seamus Deane, The Field Day Anthology of Irish Writing (Derry: Field Day, 1991), p. 69.

34 Medbh McGuckian, Horsepower Pass By! A Study of the Car in the Poetry of Seamus Heaney (Coleraine: The Cranagh Press, 1999), p. 2.

35 Seamus Heaney, 'Night Drive', Door into the Dark (London: Faber, 1969), p. 34.

36 Seamus Heaney, 'The Tollund Man', Wintering Out (London: Faber, 1972), p. 48.

37 Seamus Heaney, 'On the Road', Station Island (London: Faber, 1984), p. II9.

38 Seamus Heaney, 'The Little Canticles of Asturias', Electric Light (New York: Farrar, Straus and Giroux, 200I), p. 28.

Seamus Heaney, 'High Summer', Field Work (London: Faber, 1979), p. 46. 
five miles an hour, ${ }^{\prime 40}$ along the 'dewy motorway, ${ }^{41}$ through insects' 'hail of bright chaff', '42 'turning a corner, taking a hill / In County Down, ${ }^{43}$ 'beyond Coleraine,' ${ }^{34}$ 'by remote control on this bare road', ${ }^{45}$ ' into a meaning made of trees / Or not exactly trees, ${ }^{36}$ and across the border. ${ }^{47}$ And, of course, into and through the west of Ireland: round the peninsula, ${ }^{48}$ across the Burren to the coast, ${ }^{49}$ towards Lough Derg, ${ }^{50}$ along the Flaggy Shore, ${ }^{51}$ through Connemara $^{52}$ and the Gaeltacht, ${ }^{53}$ and along the Atlantic Drive. ${ }^{54}$

There are several striking features about Heaney's poetry of the car journey. Many of them are undertaken with somebody else - with either a 'real' person, or with the memory or the spectral presence of a person: 'When you're on the road / give lifts to people, you'll always learn something', the ghost of a schoolmaster advises him..$^{55}$ Also striking is the fact that so

40 Seamus Heaney, 'Dawn', Wintering Out (London: Faber, 1972), p. 77.

4I Seamus Heaney, 'This morning from a dewy motorway', Wintering Out (London: Faber, 1972), p. 5 .

42 Seamus Heaney, 'At Ardboe Point', Door into the Dark (London: Faber, 1969), p. 35 .

43 Seamus Heaney, 'Shoreline', Door into the Dark (London: Faber, 1969), p. 51.

44 Seamus Heaney, 'Squarings/Lightenings, xlviii,', Seeing Things (London: Faber, 199I), p. 108.

45 Seamus Heaney, 'Elegy for a Still-born Child', Door into the Dark (London: Faber, 1969), p. 32.

46 Seamus Heaney, 'Squarings/Lightenings, xxxi', Seeing Things (London: Faber, 1991), p. 89 .

47 Seamus Heaney, 'From the Frontier of Writing', The Haw Lantern (London: Faber, 1987), p. 6.

48 Seamus Heaney, 'The Peninsula', Door into the Dark (London: Faber, 1969), p. 9.

49 Seamus Heaney, 'Oysters', Field Work (London: Faber, 1979), p. iा.

so Seamus Heaney, 'Station Island, ii', Station Island (London: Faber, 1984), p. 64.

5I Seamus Heaney, 'Postscript', The Spirit Level (London: Faber, 1997), p. 70.

52 Seamus Heaney, 'Ballynahinch Lake', Electric Light (New York: Farrar, Straus and Giroux, 200I), p. 30.

53 Seamus Heaney, 'Clonmany to Ahascagh', Electric Light (New York: Farrar, Straus and Giroux, 200I), pp. 90-I.

54 Seamus Heaney, 'The Gaeltacht', Electric Light (New York: Farrar, Straus and Giroux, 200I), p. 5 I.

55 Seamus Heaney, 'Station Island, v', Station Island (London: Faber, 1984), p. 73. 
many of these journeys are interrupted, sometimes benignly but at other times aggressively. And the nature of these interruptions is, unsurprisingly perhaps, very much a matter of politics. When he drives in the North, it is more often than not the forces of the state that ruin the journey:

When our rebel anthem played the meeting shut we turned for home and the usual harassment by militia on overtime at roadblocks. ${ }^{56}$

Driving home in his Austin 16 after a date,

policemen

Swung their crimson flashlamps, crowding round

The car like black cattle, snuffing and pointing

The muzzle of a Sten gun in my eye:

'What's your name, driver?'

$$
\begin{aligned}
& \text { 'Seamus...' } \\
& \text { Seamus? } \text { ? }^{57}
\end{aligned}
$$

And while trying to drive across the border from the North to the Republic, he is held under the gaze of the 'marksman training down / out of the sun upon you like a hawk. ${ }^{58}$ It is not, however, always the B-Specials or the RUC who impede his progress by car. In 'The Flight Path's9 Heaney dreams of being flagged down on a mountain road by Ciaran Nugent the IRA volunteer who in March 1976 precipitated years of blanket and dirty protests against the British government's policy of criminalisation of political prisoners - who orders the poet to drive a car-bomb to the customs post at Pettigo, a village on the Derry-Donegal border. Such a

56 Seamus Heaney, 'From the Canton of Expectation', The Haw Lantern (London: Faber, 1987), p. 46.

57 Seamus Heaney, 'Singing School/The Ministry of Fear', North (London: Faber, 1975), p. 64.

58 Seamus Heaney, 'From the Frontier of Writing', The Haw Lantern (London: Faber, 1987), p. 6.

59 Seamus Heaney, 'The Flight Path', The Spirit Level (London: Faber, 1997), pp. 24-5. 
sense of danger recurs throughout the poetry. One of his most anthologised poems, 'Mid-term Break', recalls the fatal damage done by a speeding car's bumper to the poet's younger brother; in a later elegy Heaney mourns Rachel killed by, in Medbh McGuckian's apt phrase, 'the unmentioned, perhaps unmentionable car'; ${ }^{60}$ in 'Station Island' the 'old Land Rover' brings the assassins to the door of the doomed shopkeeper; and in 'The Strand at Lough Beg' the poet's second-cousin Colum McCartney is, most probably, flagged down by his killers at a fake roadblock. In 'Keeping Going' Hugh Heaney's 'big tractor' pulls up at the Diamond with an altogether different purpose and effect than that of the part-time police reservist's killers' car that earlier has

Crossed the Diamond, slowed again and stopped

Level with him, although it was not his lift. ${ }^{61}$

However, once Heaney is beyond the confines of the Northern statelet, once its anxiety-infused border is breached, there is in his car poetry a pleasurable sense of movement that seems to have little in the way of anxiety attending it. Time and again Heaney articulates a powerful sense of deterritorialisation, a purposeful uprooting, a skimming of surfaces. This is a poet who seems to actually enjoy driving:

Travelling south at dawn, going full out

Through high-up stone wall country, the rocks still cold,

Rainwater gleaming here and there ahead,

I took a turn and met the fox stock-still,

Face-to-face in the middle of the road. ${ }^{62}$

One of Heaney's earliest poems of the road is concerned with a journey through the West, all the more mythically 'western' because of its contiguity

60 McGuckian, Horsepower Pass By!, p. 8.

6I Seamus Heaney, 'Keeping Going', The Spirit Level (London: Faber, 1997), p. I2.

62 Seamus Heaney, 'Squarings/Crossings, $x x v$ ', The Spirit Level (London: Faber, 1997), p. 83 . 
to the Northern statelet. In 'The Peninsula' Heaney suggests that if we 'just drive / For a day all round the peninsula' we will return changed, cleansed, and bearing a certain quasi-mystical knowledge:
And drive back home, still with nothing to say
Except that now you will uncode all landscapes
By this: things founded clean on their own shapes,
Water and ground in their extremity. ${ }^{63}$

In the poem, place is not experienced in the contemplative manner in which Derek Mahon, say, contemplates the dozing salmon or the weaving spider ('The Mayo Tao'). Nor is it the close and patient observations of the flora and fauna of Carrigskeewaun undertaken over the years by Michael Longley. Heaney is very much a traveller passing quickly over territory and through landscapes. At the same time as affording pleasure and consolation, Heaney's car journeys more often than not lead toward an unrecuperable lack of signification and ontological certainty. Glimpsed from the window of a passing car, objects in the landscape become simulacra bearing, or producing in the brief encounter with the viewer/poet, only the effect (transient and immaterial at that) of what passes for truth:

The land without marks, so you will not arrive

But pass through. ${ }^{64}$

'The land without marks': an extraordinarily poignant admission of the rupture of eco-relationship between the human passing too quickly across territory that is for him 'without marks' (features, inscriptions, language) but is for others, presumably, full of significance. As opposed to Heaney's celebrated 'sense of place', this type of movement through territory is an instance of 'placelessness, ${ }^{\prime}{ }^{65}$ and as such it represents a strand within Heaney's work that is rarely commented upon. While driving Heaney's relation to place is startlingly insubstantial. In lieu of secure knowledge

63 Heaney, 'The Peninsula', p. 9.

64 Heaney, 'The Peninsula', p. 9.

65 See Edward Relph's Place and Placelessness (London: Pion, 1976). 
and attachment to place and objects there is a hypersensitivity to fleeting images and signs: there is no lingering in phenomena. The distance between, on the one hand, the traveller and the territory he passes across, and on the other, the eco-relationship of 'native' or 'dweller' in particular place can be appreciated if we compare Heaney's 'land without marks' with, say, Desmond Fennell's description of the encryption of place and placenames on the island of Maoinis, off Carna in Connemara:

Every large rock on sea or land, every cove and field, every rise or turn on the road, has a name. Consequently, as one looks out across a scene, it is not a mere 'scene', but a dense web of names, a minutely intelligible grid in which one can fix the position of a man or a thing precisely. ${ }^{66}$

Likewise, from his vantage point at the deserted Loch Swilly line railway station at Caiseal na gCorr, the Donegal poet Cathal Ó Searcaigh reads the landscape as intimately known text:

This is the poem-book of my people, the manuscript they toiled at with the ink of their sweat. Here every enclosed field is like a verse in the great poem of land reclamation. ${ }^{67}$

'The Peninsula' offers a suggestive but transitory 'truth': one that cannot be communicated ('and drive back home, still with nothing to say') and one that remains located in a literal darkness ('and you're in the dark again.') The weight of the poem's argument rests upon the pedestal of the final assertion. Separated from the rest of the poem by the hinge of a colon, this is the 'truth' of the journey round the circular corridor of the peninsula (which seems to be, more likely than not, the Inishowen Peninsula of Country Donegal):

66 Desmond Fennell, 'The Last Years of the Gaeltacht', in The Crane Bag, 1981, 5:2, p. 839 .

67 Cathal Ó Searcaigh, 'Here at Caiseal na gCorr Station'/‘Anseo ag stáisiún Chaiseal na gCorr', in An Bealach 'na Bhaile / Homecoming, trans. Gabriel Fitzmaurice (Indreadhán, Conamara: Cló Iar-Chonnachta, 1993), p. 95. 
... now you will uncode all landscapes

By this: things founded clean on their own shapes,

Water and ground in their extremity.

The poem articulates the consolations not of intimately-known geography, but the pleasures and sensations evoked by a certain manner of looking at that geography: it is an instance of, in John Urry's resonant phrase, 'the tourist gaze. ${ }^{68}$ There are echoes here of Jean Baudrillard's journeying across the deserts of the American West in search of 'l'Amérique sidérale' ('astral America'):

Speed creates pure objects. It is itself a pure object, since it cancels out the ground and the territorial reference-points, since it runs ahead of time to annul time itself, since it moves more quickly than its own cause and obliterates that cause by outstripping it. Speed is the triumph of effect over cause, the triumph of instantaneity over time as depth, the triumph of the surface and pure objectality over the profundity of desire ... Driving like this produces a kind of invisibility, transparency, or transversality in things, simply by emptying them out.... Perhaps, though, its fascination is simply that of the void ... Speed is simply the rite that initiates us into emptiness: a nostalgic desire for forms to revert to immobility. ${ }^{69}$

'Postscript' is an elaboration of the negative ontology of 'The Peninsula' and is also a meditation on the hyper-reality of the west of Ireland. Beginning in media res, in the intermezzo, as if the entire thing were an addition to something already said, a supplement to the volume (The Spirit Level) of which it is the afterthought, the afterwritten, the postscriptum, the poet encourages the reader to undertake a repetition of a journey he has already, seemingly, undertaken. Simultaneously, the poem looks forward and backward:

And some time make the time to drive out west Into County Clare, along the Flaggy Shore, In September or October. ${ }^{70}$

68 See John Urry's The Tourist Gaze: Leisure and Travel in Contemporary Societies (London: Sage, 1990).

69 Jean Baudrillard, America (London and New York: Verso, 1988), pp. 6-7.

70 Heaney, 'Postscript', p. 70. 
On the face of it 'Postscript' might seem to be firmly in the tradition of journeys into the Irish West so beloved of the revivalists, but in fact it breaks with the entire tradition of westward vectorialism in Irish writing. The poem is an articulation and a promise of a form of pure Baudrillardian effect: there is precisely nothing to be gained from this journey through the physical and intertextual (Yeatsian swans occupy four lines of this sixteenline poem) landscape of the Burren coastline. This is landscape once again glimpsed through the toughened glass of the car's windows. The car is a framing device, a field of interrupted vision, and so the road delivers its spectacles only meagrely. With speed, as Baudrillard reminded us earlier, the 'real' is irretrievably lost only to be experienced in the always belated, backward glance:

Useless to think you'll park and capture it

More thoroughly. You are neither here nor there,

A hurry through which known and strange things pass

As big soft buffetings come at the car sideways

And catch the heart off guard and blow it open. ${ }^{71}$

In its unsettled and deterritorialized différance, there is no penetration (despite the urge to drive 'into County Clare') into an actual or real west, into an authentic Irish westernness. The drive here is, as Freud theorized all drives to be, polymorphously oriented. There is no single goal: there is rather sensation, pleasure and, in the final line, amazement at the eirenic force of the west as a distillation of sight, light, movement and, indeed, textuality.

The second mode of displacement comes about when we read the natal place itself not in the orthodox way as a point of origin but against the grain, as it were, as a space shot through with difference(s). On more than one occasion Heaney has invoked the den-like existence of his and his siblings' childhoods, but what is striking is that each articulation of this world registers intrusions from beyond its apparently tightly-bound geography. These influences seem to have preceded any sense of the poet's well- 
known renderings of the divisions and subtle accommodations between Catholic and Protestant, between loyalist and rebel; the type of strains Heaney enacts in poems such as 'The Other Side', 'A Constable Calls', 'An Ulster Twilight, and 'Terminus'. The ways in which the poetry has often negotiated between the claims of both sides, and of his burden growing up 'in between' has been more-than-adequately dealt with elsewhere. What we are interested in here is the mesh of differences that were always already inscribed in the poet's consciousness, that precede the divisions of sect and nation. Witness the opening of his Nobel Prize lecture:

we crowded together in the three rooms of a traditional thatched farmstead and lived a kind of den-life which was more or less emotionally and intellectually proofed against the outside world. It was an intimate, physical, creaturely existence in which the night sounds of the horse in the stable beyond one bedroom wall mingled with the sounds of adult conversation from the kitchen beyond the other. We took in everything that was going on, of course - rain in the trees, mice on the ceiling, a steam train rumbling along the railway line one field back from the house - but we took it in as if we were in the doze of hibernation. Ahistorical, pre-sexual, in suspension between the archaic and the modern, we were as susceptible and impressionable as the drinking water that stood in a bucket in our scullery: every time a passing train made the earth shake, the surface of that water used to ripple delicately, concentrically, and in utter silence. But it was not only the earth that shook for us: the air around and above us was alive and signalling too. When a wind stirred in the beeches, it also stirred an aerial wire attached to the topmost branch of the chestnut tree. Down it swept, in through a hole bored in the corner of the kitchen window, right on into the innards of our wireless set where a little pandemonium of burbles and squeaks would suddenly give way to the voice of a BBC newsreader speaking out of the unexpected like a deus ex machina. And that voice too we could hear in our bedroom, transmitting from beyond and behind the voices of the adults in the kitchen; just as we could often hear, behind and beyond every voice, the frantic, piercing signalling of morse code. ${ }^{72}$

At the very moment in which an almost-prelapsarian innocence is proclaimed, we glimpse a world that is in fact saturated by emanations from elsewhere. Through that aerial come BBC Radio and Radio Eireann, to

72 Seamus Heaney, Opened Ground: Poems, 1966-1996 (London: Faber, I988), p. 447 . 
be sure, but also the broadcasts of 'foreign stations ... Leipzig and Oslo and Stuttgart and Warsaw and ... Stockholm.' And although the Morse code signal can be read quite easily as the encrypted language of the tribe entering into the chora-like existence of the children, it is more than likely that it is merely radio interference from the nearby United States Army Air Force base at Creagh, out of which A-20 Havoc and B-26 Marauder bombers flew on countless training missions between the summer of 1943 and November 1944. The air above Creagh and Toome was busy with their movements. And only a field away from the farmhouse ran the line of the Midland and Scottish Railway that impinges constantly on the childhood world of the poet. The line provides a theatre of sensation that is returned to time and again:

I used to lie with an ear to the line

For that way, they said, there should come a sound

Escaping ahead, an iron tune

Of flange and piston pitched along the ground,

But I never heard that. ${ }^{73}$

When we climbed the slopes of the cutting

We were eye-level with the white cups

Of the telegraph poles and the sizzling wires. ${ }^{74}$

I stood on the railway sleepers hearing larks, Grasshoppers, cuckoos, dogbarks, trainer planes ... ${ }^{75}$

... I'd lie

Listening for the goods from Castledawson..${ }^{76}$

73 Seamus Heaney, 'Glanmore Sonnets, iv', Field Work (London: Faber, 1979), p. 36.

74 Seamus Heaney, 'The Railway Children', Station Island (London: Faber, 1984), p. 45 .

75 Seamus Heaney, 'Squarings/Settings, xiv', Seeing Things (London: Faber, I991), p. 70.

76 Seamus Heaney, 'Polish Sleepers', District and Circle (London: Faber, 2006), p. 6. 
The rails, the sizzling telegraph wires that 'curved for miles / East and miles west beyond us, ${ }^{77}$ the creosoted railway sleepers imported from Poland: all provide routes to and beyond the horizon. As palpable a presence in the poetry as the yard or the byre, the rails provide a centrifugality that will open the poet to a cosmopolitanism barely registered in criticism of the poetry (especially in comparison, say, to the internationalism of Mahon and Muldoon). The routes opened up by the London and Midland railway will lead eventually to Lourdes, to London, to Berkeley, to Belgrade, to Olympia, and will accumulate in a later poetry of excited concatenation, such as here in 'The Flight Path':

Up and away. The buzz from duty free.

Black velvet. Bourbon. Love letters on high.

The spacewalk of Manhattan. The re-entry.

Then California. Laid-back Tiburon.

Burgers at Sam's, deck-tables and champagne,

Plus a wall-eyed, hard-baked seagull looking on.

Again, re-entry, Vows revowed. And off - ${ }^{78}$

Reading across Heaney's oeuvre it is remarkable how congested, how dynamic is his immediate homeground: and increasingly so. As each volume 'returns' to the farm, to the byre, to the yard; as it presents for the first time in poetry new versions of the Lagan's Road, Anahorish School, the aerodrome, differences through accumulation are endlessly produced. The world brought into being by the poetry is replete with objects, memories, fears, and sensations; is constituted by events, dates, and people. Increasingly his poetry registers an early world by no means insulated from the social formations and cultural influences of province and state, but thoroughly shot-through with signs that are enticingly, excitingly air-borne, mediated, and global. Heaney's relationship to the land, to the local, to the homeground has to be rethought. Alongside the Antaean attachments

77 Heaney, 'The Railway Children', p. 4

78 Heaney, 'The Flight Path', pp. 23-4. 
to what lies below, there is a realm of pleasurable difference that emanates not from the earth but from the air, from radio, cinema, and song. We wish to suggest (all too briefly here) that the poetry has always rendered a world of multiple sources out of which (and in the manner of Sean O'Riada who, on 'the most westerly Blasket', plucks an air 'out of wind'79) Heaney has made his music. This multiplicity was there all along, but it is in the later poetry, in particular, that the poet has most fully begun to re-vision his childhood world as more a confluence of 'native' and 'foreign' impressions; as a world busier, more complex, more open to, yes, the 'global' than is normally admitted. Tinkers, B-Men, POWs, labourers, plasterers, thatchers, demobbed soldiers, pass through his immediate territory. And always, buses and cars and lorries and tractors, passing into, through, and out of this mesh of a childhood terrain. But also, incongruously, bomber planes and columns of American soldiers:

Two lines of them, guns on their shoulders, marching.

Amoured cars and tanks and open jeeps.

Sunburnt hands and arms. Unknown, unnamed,

Hosting for Normandy. ${ }^{80}$

The homeground is also a plateau across which a rich literary and cultural intertextuality is at play: Byron and Keats (recited in the zinc-roofed Nissen hut of Anahorish schoolhouse), Irish ballads, 'scurrilous and sectarian' chants, the 'cultural debilitations' of Our Boys and Ireland's Own and also Champion, Rover, Hotspur, the Wizard, Far East, the Messenger, Dandy, Beano, Irish Weekly, Northern Constitution, Irish myths and legends, Treasure Island, Kidnapped, Lorna Doone, and later The Return of the Native. And through that aerial came signals carrying 'the thrill of story, such as a detective serial about a British special agent called Dick Barton or perhaps

79 Seamus Heaney, 'The Given Note', Door into the Dark (London: Faber, 1969), p. 46.

80 Seamus Heaney, 'Anahorish 1944', District and Circle (New York: Farrar, Straus and Giroux, 2006), p. 7. 
a radio adaptation of one of Capt. W.E. Johns's adventure tales about an RAF flying ace called Biggles.'

In his Nobel Lecture, Heaney recognised that it is through this hybrid radio and literary culture that he began his:

journey into the wideness of the world beyond. This in turn became a journey into the wideness of language, a journey where each point of arrival - whether in one's poetry or one's life - turned out to be a stepping stone rather than a destination. ${ }^{81}$

We like this final phrase. It confirms our sense of Heaney's work as an endless becoming. And, yet, doesn't it seem odd to talk about a return as becoming? Not if we think of home slightly differently than is normally the case. We have taken our cue here from Marina Warner's final 1994 Reith Lecture in which she asks if there might be 'another way of talking about home, without harking back to nostalgic lies about the hearth, the throne, the greensward, the island race ${ }^{>2}$ Home, and its metonyms, hearth and earth, she argues:

returns us once more to mum, she who embodies birthplace as well as the larger allegories of native land, and by extension of nation.... Home in myth promises an end to questing, to wandering ... home is closure, the arrival brings the story to an end. ${ }^{83}$

Heaney's returns to the 'homeground' produces through repetition and difference the converse of such closure. 'Home', and what it might represent, is constantly renewed through the irreducible difference that comes about when a new poem adds an estranging supplement to the existing work. 'Home', like the house, is never finished. In fact, more (or, indeed, less) than that, it is, as Marina Warner observes, always just out of reach: 'Home lies ahead, in the unfolding of the story in the future, not behind waiting to be regained. ${ }^{34}$

8I Heaney, Opened Ground, p. 448.

82 Marina Warner, Managing Monsters: Six Myths of Our Time (London: Vintage, 1994), p. 92.

83 Warner, Managing Monsters, p. 88.

84 Warner, Managing Monsters, p. 82. 


\section{Irish Theatre and Globalisation: A Faustian Pact?}

PATRICK LONERGAN

In May 2008, the Abbey Theatre staged The Seafarer, a new play by Conor McPherson. In many ways, it seems a typically Irish work: it involves a group of under-achieving working class men who talk (and drink) to excess, and it presents audiences with one of the Irish stage's most familiar scenes: the filthy living space, cluttered with empty whiskey bottles, with a sacred heart statue perched on the wall. What makes the play seem a little unusual, however, is that one of its characters is none other than the devil incarnate. The Seafarer blends the old Dublin tale of the Hellfire Club with elements of the Faust legend, which are brought into the present-day setting of a house on Dublin's northside. It's Christmas Eve, and a group of men have gathered to play a game of cards; they are joined unexpectedly by a stranger called Lockhart, who, it turns out, is Satan in human form, come to Dublin to win the soul of the play's protagonist, Sharky. 'I'm the son of the morning, Sharky', he says. 'I'm the snake in the garden. I've come here for your soul this Christmas, and I've been looking for you all fucking day!'

Sharky, we learn, had bartered his soul in a game of cards with Lockhart twenty-five years previously (in 1981, according to the play's chronology), when he was arrested after a drunken brawl that resulted in the death of a homeless man. Because he won that game, Sharky was never charged with his crime, but Lockhart demanded the right to play him again. Sharky has spent the subsequent quarter-century trying to forget his crime, and the deal that followed it: he drinks heavily, has separated from his partner

I Conor McPherson, The Seafarer (London: Nick Hern Books, 2006), p. 47. Subsequent references to this play appear parenthetically in the text. 
and (apparently) from his children, ${ }^{2}$ and he has lost one job after another. So McPherson's characterisation of Sharky slightly inverts the story of Marlowe's Doctor Faustus, who sold his soul in exchange for twenty-four years on Earth with Mephistopheles as his servant. Both Faustus and Sharky enjoy roughly the same period of time enjoying an undeserved and ultimately damaging freedom, but McPherson begins his play where Marlowe's ends - at the moment when the debt must finally be repaid.

Perhaps it's a sign of the strength of McPherson's writing that he manages to keep his audience's faith as his plot progresses. One of the ways he achieves this is by using financial rather than religious language to convey the fantastical elements of his plot. For instance, if Sharky loses his game of cards, Lockhart promises to take him to hell through what he calls 'the hole in the wall' - a rather sinister sounding phrase that also happens to be a colloquialism for an ATM (pp. 76, 96). And when he's asked to describe what it's like to fall from heaven into hell, Lockhart replies as follows:

Well you know, Sharky, when you're ... standing outside a shop where you were hanging around reading the magazines, pretending to buy one 'cause you've no money and nowhere to go ... And you see all these people who seem to live in another world all snuggled up together in the warmth of a tavern or a cosy little house, and you just walk and walk and walk and you're on your own and nobody knows who you are. And you don't know anyone and you're trying not to hassle people or beg, because you're trying not to drink ... Well, that's a fraction of the self-loathing you feel in Hell, except it's worse. (p. 77)

Being in hell, in other words, is like being penniless in Dublin today.

There are clear parallels between Sharky's situation and Lockhart's both men have fallen from a state of grace, and both are tortured not just by the harshness of their circumstances, but also by the memory of what they have lost. Irish audiences at this play are the very people whose 'cosy little homes' Sharky gazes into; we are the people from whom he tries not school run' (p. 29). This, presumably, means that he she uses it to bring children to and from school; it is unlikely that Sharky would have felt compelled to give up his car if those children were not his own. 
to beg; we are the occupants of that 'other world' from which Sharky - and Lockhart - are both excluded.

McPherson's use of economic language to convey his sense of unease with recent social developments isn't unusual. The story of Faust has broad resonances, but one of its major features is that it often appears in societies that are facing a crisis of valuation, in which something that should be free from the economic suddenly becomes commoditised. Goethe, for instance, writes extensively about the idea of paper money in Faust Part Two (1832), asking how something apparently valueless - paper - can act symbolically as a sign of actual wealth. ${ }^{3}$ It is interesting that we see McPherson deploying this myth again, at a time when Ireland is struggling with its sense of values, and trying to come to terms with the country's rapid enrichment between 1993 and 2007. Ireland, after all, has become a place where the words 'wealth' and 'prosperity' are frequently confused; indeed, it often feels like the country has itself entered into something of a Faustian pact. It should be noted in that context that McPherson is only one of a number of Irish writers who has turned to the Faust myth in recent years: the motif also appears in Marina Carr's Ariel (2002) and Mark O'Rowe's Terminus (2007), and is also a feature of Tom Murphy's 1983 masterpiece The Gigli Concert, which has been revived twice at the Abbey Theatre since $200 \mathrm{I} .{ }^{4}$

McPherson has drawn an explicit parallel between his play and contemporary Irish insecurities about money. 'We're not comfortable with success in this country,' he said, shortly before The Seafarer opened in Dublin. 'It's post-traumatic stress from our colonial past or whatever.' He went on to say

For a consideration of this issue, see Hans Christoph Binswanger, Money and Magic: Critique of the Modern Economy in the Light of Goethe's 'Faust', trans. John E. Harrison (Chicago: University of Chicago Press, 1994).

4 Many other Irish plays use a version of the Faust myth, from Yeats's Countess Cathleen in 1892 to Zoe Seaton's To Hell With Faust in 1998. We've even seen Satan on the Irish stage before, in Joseph Tomelty's 1953 comedy Down the Heather Glen. And there have been plays about such themes as demonic possession and exorcism too, most notably Frank Carney's The Righteous are Bold, which was an enormous success at the Abbey in 1946, and which appeared on Broadway in 1955-6. The Gigli Concert was produced at the Abbey Theatre in September/October 200I, and again in October 2004 in a production that also toured to Brisbane. 
that Irish people seemed relieved by news that recession was looming. 'Ireland is going to get back to what it knows now - hardship' said McPherson. 'That's where we're more comfortable. We can't wait for it to start'.

I am not suggesting that we should agree with McPherson's assessment of Irish attitudes to recession, but his statement does offer one way of understanding how he sees his own work. His characters generally are people who 'aren't comfortable with success', who embrace hardship because it is what they know best. So the Celtic Tiger period, for McPherson, cannot be represented in terms of the epic grandeur of an overreaching hero like Marlowe's Doctor Faustus. It is instead represented as a twentyfive year bender by a washed-up alcoholic who is desperate to forget his past, and who has gambled his soul because he never thought it could be worth saving in the first place. That decision - to sell your soul because you don't believe you actually have a soul - could be seen as another allusion to Marlowe's play, but it can also be interpreted as a harsh view on the values of Celtic Tiger Ireland. For that reason, the play has much to offer a contemporary Irish audience, exploring and explaining contemporary developments at a time when the country is confused about its sense of identity and its direction.

Irish audiences have had to wait quite a while to hear this message first hand, however. The Seafarer opened at the Abbey on 7 May 2008, almost two years after its premiere in London (it opened on 28 September 2006). The play has also been seen on Broadway, where it was nominated for four Tony Awards, eventually winning one of them. ${ }^{6}$ The play's production in 2008. See http://archives.tcm.ie/businesspost.ie/2008/04/27/ story32265.asp (accessed 4 May 2008).

6 The play was nominated for the following awards: Best Play, Best Performance by a Featured Actor in a Play (Conleth Hill), Best Performance by a Featured Actor in a Play (Jim Norton), and Best Direction of a Play (Conor McPherson). Norton won the award for his performance. 
Dublin thus occurred only after it has been seen in the two major global centres for theatre. The London and New York productions were directed by McPherson himself, and featured leading Irish actors such as Jim Norton, Conleth Hill, and (in New York) Ciarán Hinds.

McPherson speaks frankly about his unwillingness to premiere his 'typically Irish' plays before typical Irish audiences. Since 1997, only one of his plays has opened in Dublin because, Michael Colgan claims, McPherson is 'not going to put up with the level of criticism' in Ireland. ${ }^{7}$ In a pre-show talk at the Peacock Theatre in 2002, McPherson elaborated on this element of his career, stating that to open his plays in Dublin would involve reducing the likelihood that his work would travel internationally, be published, and be reviewed by people who actually know something about theatre. 'You could say I've embraced globalisation,' McPherson stated in 2007 - and it's true that his work functions in much the same way as other elements of global culture. ${ }^{8}$ His plays are premiered in the globalised core - the West End and Broadway - before being franchised out to the periphery, including Dublin itself.

McPherson is by no means unique in this context. Between $200 \mathrm{r}$ and 2007 , a total of 263 new Irish plays were produced, according to the Irish Playography. Of those, twenty-two premiered abroad - roughly 9 per cent of the overall total. That proportion might not seem problematic, until we consider what those plays were and whom they were written by. They include the newest plays of almost every major Irish dramatist: Tom Murphy, Sebastian Barry, Marina Carr, Martin McDonagh, Mark O’Rowe, Enda Walsh, Marie Jones and Frank McGuinness. These include important new works by younger Irish dramatists, such as Colin Teevan's How Many

7 Qtd in Lilian Chambers, Ger Fitzgibbon and Eamonn Jordan (eds) Theatre Talk: View of Irish Theatre Practitioners (Dublin: Carysfort Press, 200I), p. 87. The only McPherson play to open in Dublin was his one-act Come On Over, which was staged at the Gate in October 2003 as part of a triple bill that featured short works by Brian Friel and Neil Jordan.

8 Khokhar, Ahmer, 'Drink nearly killed me: McPherson', Sunday Independent, 3 June 2007, http://www.independent.ie/national-news/drink-nearly-killed-me-mcpherson-690739.html. 
Miles to Basra? (2006), a fascinating play that explores the British Army's presence in Iraq in relation to the Northern Irish Troubles, and Stella Feehily's Duck (2003), about a young woman in Celtic Tiger Dublin, and O Go My Man (2006), which is explicitly about globalisation.'

What this list means - put simply - is that many of the best and most significant Irish plays of the last decade have never been seen in Ireland; others have appeared only for short runs - perhaps four or five days - in touring productions from England. What is ironic in this context is that most of those plays are successful internationally precisely because they are branded as Irish; they are successful because of their association with a geographical space that they have little or no relationship with. Just as Goethe would ask how a piece of paper can symbolise real wealth that is stored somewhere else, these plays symbolise Irishness without literally being from Ireland. It could be argued, therefore, that Irish theatre has itself entered into something of a Faustian pact, embracing globalisation in a way that involves commoditising its most essential characteristics.

The impact of globalisation on theatre has resulted in a growing flexibility in the relationships of writers with theatres everywhere. In recent years, Neil LaBute and David Mamet have produced new work in London, Patrick Marber has premiered work in New York, and Edward Bond's Crime of the Twenty-First Century (2001), Sheelagh Stevenson's Enlightenment (2005), Neil LaBute's Wrecks (2005), and Sam Shepard's Kicking A Dead Horse (2007) all premiered in Ireland. Ireland's theatre - like the theatres of many other countries - is undergoing a paradigmatic shift that involves a

The full list is: Sebastian Barry, The Pride of Parnell Street and Hinterland; Marina Carr, Woman and Scarecrow; Stella Feehily, Duck and O Go My Man; Marie Jones, Rock Doves*; Owen McCafferty, Scenes from the Big Picture; Martin McDonagh, The Lieutenant of Inishmore and The Pillowman; Frank McGuinness, Speaking like Magpies* and There Came A Gypsy Riding*; Conor McPherson, Shining City, Port Authority, The Seafarer; Gary Mitchell, Loyal Women; Tom Murphy, Alice Trilogy; Edna O’Brien, Triptych*; Christian O'Reilly, Is This About Sex?; Mark O’Rowe, Made in China; Colin Teevan, How Many Miles to Basra?*; Enda Walsh, The New Electric Ballroom and The Small Things. Plays marked with an asterisk have never been produced in Ireland. 
realignment of its sense of space and movement. For much of the twentieth century, the Irish theatre was a vertical network - a hierarchy - with the Abbey Theatre at its pinnacle. Now the Abbey and Ireland's other theatres have become hubs on a horizontal network that is spread out globally. Writers like McPherson will naturally be drawn to the most prominent 'hubs' on that international network - the West End and Broadway. Meanwhile, theatres like the Abbey must define their place on that network, 'branding' themselves in ways that differentiate them from their international competitors. Hence, the theatre's production of work by Sam Shepard is an important statement of intent: Dublin can be one of the major centres for the development of new writing, the Abbey is suggesting. Similarly, its international tours of such plays as Mark O'Rowe's Terminus can be seen as an attempt to highlight those features of Irish drama that make it stand apart: poetry of speech, a focus on the urban working classes, an emphasis on the supernatural and fantastic, and so on. These developments are complex, and arise from a set of interlinking processes, many of which develop independently of each other. No individual or group is building or managing the network I'm describing; it is instead a web of interlinking processes that is constantly developing. Nevertheless, it is possible to note a number of common features. ${ }^{10}$

The dominant value in the global theatre network is mobility. Mobility in theatre, as in many other aspects of life, has become a signifier of success - it is the 'most powerful and most coveted stratifying factor' in contemporary society, as Zygmunt Bauman puts it ${ }^{11}$ - and thus has become desirable for writers, producers, and actors. This affects the production, reception, and study of theatre and other forms of literature and culture. This was evident in the marketing of the Abbey's production of The Seafarer, which used McPherson's Tony Awards nominations in New York as a way to tell their Dublin audiences that the play is worth seeing. So in New York, people went to see the play because it was Irish, but in Ireland, they Globalization: Irish Drama in the Celtic Tiger Era (London: Palgrave, 2009). 
were encouraged to see it because it was successful in New York. Mobility is therefore seen as inherently positive, but it's possible to use the term in other ways too. For instance, one of the reasons that The Seafarer has been successful internationally is that it is literally mobile: it has a relatively small cast (it offers parts for five middle-aged men), and low production values, and can therefore travel internationally without excessive expense.

Another form of theatrical mobility is the capacity to cross cultural and geographical barriers. Many different modes of reception occur on the global theatre network because of the importance of mobility. Some plays travel widely because they deal with concerns that audiences think of as 'universal'. Others are successful because they are examples of what Dan Rebellato has termed 'McTheatre': plays that set out to please their audiences instantly but superficially. ${ }^{12}$ However, the major determinant of a play's success on the global stage is its reflexivity: its ability to allow audiences to relate the play's meaning to personal or local contexts. Hence, we often see plays provoking overwhelmingly different responses as they tour globally - a phenomenon that is especially notable in the plays of Martin McDonagh. His Lieutenant of Inishmore, for instance, is seen in some countries as an attack on terrorism, and in others on the governments who are engaged in the so-called war against terrorism. ${ }^{13}$

One of the ways that producers aid a reflexive response to their work is through branding. What is being sold is not access to a play, but the right to participate in a staged experience - the entire experience of going to the theatre - about which the consumer will have strongly pre-determined expectations. Thus, to see a play that is branded as 'Irish' does not mean that we encounter a work that literally originated in Ireland itself. It means that we consume a work that accords with our pre-defined notions of Irishness. It is not important the work be Irish; it is important instead that as people

I2 Dan Rebellato, 'Playwriting and Globalisation: Towards a Site-Unspecific Theatre', Contemporary Theatre Review, I6:I (2006), pp. 97-I13.

I3 For more on the international reception of this play, see Patrick Lonergan, "'The Laughter Will Come of Itself; the Tears are Inevitable”: Martin McDonagh, Globalization and Irish Theatre Criticism', in Karen Fricker and Brian Singleton (eds), Irish Theatre Criticism, Special Issue of Modern Drama, 47:4, 2004. 
consume it, they are aware that it seems Irish. So Irishness has become deterritorialised - the word 'Irish' doesn't signify a relationship with a physical space, but a relationship with a concept.

A problem arising from this development is that local audiences are inevitably losing opportunities to generate meanings about their own localities. If productions are conceived with one eye on the mass market, then issues of specifically local importance can only be presented implicitly, if they are presented at all - so if McPherson's The Seafarer is about Celtic Tiger Ireland, we can only see that element of the play if we are prepared to read between the lines. Any production that dealt explicitly with issues of local importance would risk being relevant only in Ireland. Given that dramatists depend for their livelihood on international productions, translation, and the revival of their works by professional and amateur groups, it therefore seems foolish to be topical.

This of course is not a new problem. Irish theatre is in many ways uniquely positioned to benefit from globalisation, since Irish literature generally has always tended towards internationalism. Many of the great Irish texts of the seventeenth-century consider the impact of what we would now call the globalisation of trade. Some of Swift's works, for instance, expose how the production of goods for export and the strategic use of tariffs can have devastating consequences for a vulnerable population. Goldsmith's 'Deserted Village' (1770) imagines the destruction of a rural idyll, which is caused partially by the relentless pursuit of wealth through global trade. Sheridan's School for Scandal (1777) argues that the dissipation of the Surface brothers is a direct consequence of British imperialism: one is a hypocrite and the other financially irresponsible because both know that they can depend on the wealth of their uncle, Sir Oliver, who is due to return to London from the East Indies with their inheritance. In the nineteenth century, Dion Boucicault toured the world with his plays, devising strategies that would allow him to cross cultural boundaries more easily - strategies which were later imitated by Hollywood studios as the film industry developed. All of the great works of the Revival reveal the influences of international literature on Irish writers: of Ibsen on the plays of Synge and O'Casey, of Turgenev on the fictions of George Moore, of Dante on the works of Joyce and (later) on Beckett too. 
In the modern period, one of the best Irish plays about globalisation was written not during the Celtic Tiger period, but in the late 1960s: Brian Friel's The Mundy Scheme (1969). Focusing on F.X. Ryan, a fictitious Taoiseach who in many ways anticipates such real Irish leaders as Charles Haughey, Friel suggests that one solution to Ireland's economic woes might be to transform the west of the island into an enormous graveyard. That proposal is justified in terms of globalisation. 'The days of parochial, provincial, parish-pump thinking are over' in Ireland, states Ryan. 'Either you proudly proclaim your membership of the global village - or you die. No country can live in isolation. We are all dependent and interdependent. Commerce, trade, and business have made us all brothers. ${ }^{14}$ Globalisation is not simply desirable, Friel's protagonist states, but a matter of life and death. Friel's suggestion seems to be that Ireland can only succeed in the emerging global economy if it chooses to become an enormous memorial for the dead of the civilised West.

So when McPherson says that he is embracing globalisation, it's true that he is doing something that many of us would associate with practices that have emerged only since the mid-r990s. But it's also true that he's doing something similar to what Brian Friel did in the 1960s, and what Boucicault did in the 1860 s. What's different now is that the strategies used by writers like Friel and Boucicault are the norm: writers everywhere are being produced everywhere. Another difference is that, just as theatre has recently taken on the language and ethos of multinational business, it is also true that many businesses are starting to organise themselves like theatres. So it is possible, therefore, to think about another form of mobility: the movement of ideas between the economic and the theatrical.

Shortly after McPherson's first big New York success, Joseph Pine and Richard Gilmore published The Experience Economy (1999). The success

I4 Brian Friel, Crystal and Fox and The Mundy Scheme (New York: Farrar, Straus \& Giroux, 1970), p. 272. 
of many businesses, they argued, will be determined not by the quality of their services, but by the quality of the experience that they stage for customers. The service has become commodified, they suggested: we are no longer purchasing a product, but a memory of having experienced an event. Hence, the value of a trip to Starbucks is not determined by the quality of the beverage we consume; it instead involves participation in a staged experience that allows consumers to perform a sense of connoisseurship, and to be persuaded, while choosing from the many different varieties and recipes for their coffee, that they are exercising something like freedom of choice. Such experiences are offered by other successful multinational companies, from Disney to AOL to IBM. The use of theatrical terms in business contexts has become surprisingly common: services are 'the stage' and goods are 'props' used to engage customers, state Gilmore and Pine, who tell us that work is now a form of theatre in which we are all obliged to perform. ${ }^{15}$

This relationship between theatre and business works both ways. We've recently seen the plays of Samuel Beckett being used to inspire businesspeople - who were urged to 'fail better!' in a 2006 article by Stephen Brown (the exclamation point appears in the original article). He identifies seven principles from the pages of Waiting for Godot that can be applied to contemporary business: tenacity, brevity, contingency, ambiguity, narrativity, memory and something called 'Celticity' which apparently refers to all of the other principles. Those principles are then applied (convincingly, it must be said) to an analysis of the development of the Apple brand. ${ }^{16}$

I don't think Brown intends us to take his ideas very seriously, but it is noteworthy that an international business journal willingly published an article that featured detailed, credible analysis of Beckett. And that was not the first time that Beckett has been linked to international business. In 2003 , the Irish government went on a trade mission to China, the purpose Business School Press, 1999), passim.

I6 See Stephen Brown, 'Fail Better! Samuel Beckett's Secrets of Business and Branding Success', Business Horizons 49 (2006), pp. I6I-9. 
of which was to highlight the quality of Irish products, and to persuade Chinese investors of the unique characteristics of Ireland's society and, by extension, its workforce. They brought with them 127 individuals from seventy-seven companies and education institutions, according to the official press release. And they also brought two theatre productions. One was Riverdance. The other was the Gate Theatre's production of Waiting for Godot.

Likewise, in 2006, Ireland's Industrial Development Agency announced that Ireland was to be 'rebranded': the country's new slogan is 'Ireland knowledge is in our nature', which is part of a promotional campaign on The Irish Mind. 'What is different in Ireland is the way in which we tackle issues, solve problems and seek other new and better ways to meet needs' states the report,${ }^{17}$ attempting to differentiate Ireland from its competitors for Foreign Direct Investment in much the same way that the Abbey attempts to differentiate itself from other national theatres on the global theatre network. One of the most interesting claims made by the IDA is that the Irish approach to business' reflects a mindset and an approach that is innate, and which is likely related to the creativity that has been manifest in the Irish literary and artistic tradition' (p. 9). The implication here is that an essential set of characteristics - the Irish mind (close enough, perhaps to the Irish soul) - is a commodity that can be purchased by incoming investors. And this case is made by referring to Irish literature and art: the genius of a Beckett or a Bono arises from their national identity, the IDA suggests; and that genius will be evident in call centres, factories, and officeblocks throughout the island. This of course is complete nonsense, but it is interesting that the branding of Irish identity in and through literature is intrinsically linked with globalisation: the appearance of McPherson on Broadway is very good news for him, but it can also be used to differentiate Ireland from its competitors for FDI.

A corollary of that is that theatre-makers need to be aware that the kind of work they produce helps us to imagine globalisation. If digital technology allows globalisation to become an 'imagined community', theatre 
can imagine other kinds of community. Doing so will involve an awareness that the liveness of theatre offers something that cannot itself be mass produced or digitised: if a theatre audience has two or more people in it, it is already beginning to work against the processes of individualisation that are associated with globalisation.

The problem however is that identity and meaning no longer arise exclusively through the interplay of signifiers. Rather, due to globalisation, identity and meaning are being reconstructed as tokens in a chain of commodity exchanges: the Irish mind, the Irish play, the Irish workforce - all are up for sale, with essentialised qualities given an economic value in the global marketplace. As in any other kind of marketplace, values rise and fall. This inevitably affects the way that people think about themselves, and explains, I would suggest, why we are seeing so many plays in Ireland that focus on the idea of the Faustian pact. If the best way of attracting FDI into Ireland is to pretend that there is an 'innate' Irish temperament, then Ireland's economic wellbeing is dependent upon the entire nation's willingness to stage - or participate in - an enormous performance: even if we do not directly contribute to the presentation of 'innate' Irish qualities for global consumption, we all benefit from the success of that presentation.

A play like The Seafarer thus finds itself in a difficult double bind. On the one hand, it offers audiences a way to think about, and come to terms with, the way that globalisation affects their lives. Perhaps McPherson is doing little more than reassuring his audiences - not just in Ireland, but in London and New York too. His message is that the spiritual or the transcendent can survive in an excessively materialistic culture, which is exactly the kind of thing that people facing economic uncertainty have always wanted to hear. The Seafarer therefore can be seen as an Irish It's $A$ Wonderful Life, with John Martin's Sweet Little Mystery being played at its conclusion like a contemporary Auld Lange's Eyne.

On the other hand, however, is that there are obvious problems if Irish audiences only encounter such plays at second or third hand. It is difficult to sustain the IDA-sponsored notion that Ireland is 'innately' creative if our best dramatists consistently go elsewhere to have their work produced, and if Irish audiences only see Irish plays after they have travelled to 'more important' places. The construction of the 'Irish Mind' campaign should 
be dismissed as nonsense, but we can be alert to the obvious economic benefits that can arise from the presentation of Ireland as a 'creative' country. Irish theatres and other artistic institutions can make the case that funding the arts can 'brand' Dublin and other parts of the island in ways that will attract tourism and other forms of economic activity: an investment in a country's 'artistic infrastructure' can therefore be seen as economically worthwhile.

Crucially, however, these developments are also important for Irish audiences. The Seafarer can be seen as a fable that holds the promise of better things to come for Celtic Tiger Ireland, implying to audiences that all problems can be resolved through divine intervention - even if we don't deserve it. It is notable, after all, that McPherson's characters do little in the course of his play to merit the admiration of his audience, though perhaps it is for precisely that reason that they gain the attention of God. Put simply, Irish audiences can benefit from seeing Irish plays that address directly contemporary concerns, and it is vital that they be enabled to do so. As McPherson's play implies, it is possible for all of us to save our souls - but we must first acknowledge and repay what we owe. 


\section{Io. 'Coming of Age' (and other Fictions of Globalisation) in Three Novels by Seamus Deane, Roddy Doyle and Patrick McCabe}

WILLY MALEY

In an essay entitled 'Globalization and Culture: Placing Ireland' (2002), Honor Fagan, echoing Declan Kiberd's famous phrase, says 'if an Ireland did not already exist, globalization theory would have to invent it.' ${ }^{1}$ This is not the place to argue that the Celtic Tiger, if it ever existed, is now extinct, but it is the place to ask whether, given that an Ireland did and does exist, and that it has a long colonial history, globalisation's inventions, however ingenious, can do it justice. Fagan sees Ireland as an artful dodger among nations that puts into question neat binaries, and deconstructs the opposition between nationalism and globalisation. Fagan's argument is that Ireland, though often appropriated by those who would 'buy in totally to the ideology of globalization: if we take advantage of it, we can escape parochial nationalism', offers a more complex case that interrogates rather than endorses such cosy and complicit theories:

Many social groups in Ireland, many women especially, have always contested the smug conservative self-serving myths of Irish nationalism. Postnationalist accounts that imply that we have moved into a sea of tranquility where all conflict will be peacefully resolved in Brussels or Washington are also problematic. ${ }^{2}$

Fictions of globalisation have played an important part in criticism of Irish literature in the past two decades. By fictions of globalisation I mean both

I G. Honor Fagan, 'Globalization and Culture: Placing Ireland', in Annals of the American Academy of Political Science 58I (2002), pp. 133-43, p. 133. 
the literature of globalisation and also criticism/theory that insists on a break with the past and on the promotion of various post-isms. Simon During sees a double bind for colonised cultures that might benefit from postmodern modes of analysis yet are wary of the racism of universalism that can go with the territory:

For me, perhaps eccentrically, post-colonialism is regarded as the need, in nations or groups which have been victims of imperialism, to achieve an identity uncontaminated by universalist or Eurocentric concepts and images. Here the argument becomes complex, since post-colonialism constitutes one of those Others which might derive hope and legitimation from the first aspect of postmodern thought, its refusal to turn the Other into the Same. As such it is threatened by the second moment in postmodern thought [i.e. the tendency to totalisation/globalisation]. ${ }^{3}$

The purpose of this essay is to look at three novels from the 1990s, set in the 1950 s and 1960s, which raise questions about the history and politics behind appeals to postmodernity, postcolonialism and post-nationalism. I am interested in memory, time and trauma, in the afterlife of colonialism, and in the unfinished discourses of nation. In short the filthy tidemark on history's neck. Part of the purpose of my argument is to go back to Patrick Kavanagh's famous distinction between the parochial and the provincial and to argue for internationalisation - or internationalism - that is attentive to the local, and against a premature abandonment of rooted narratives and national allegories:

Parochialism and provincialism are opposites. The provincial has no mind of his own; he does not trust what his eyes see until he has heard what the metropolis towards which his eyes are turned - has to say on any subject. This runs through all activities.

The parochial mentality on the other hand is never in any doubt about the social and artistic validity of his [sic] parish. All great civilizations are based on parochialism - Greek, Israelite, English. Parochialism is universal; it deals with the fundamentals.

3 Simon During, 'Postmodernism or Post-Colonialism Today', in Thomas Docherty (ed.), Postmodernism: A Reader (Hemel Hempstead: Harvester Press, I993), pp. 44862, p. 449 . 
To know fully even one field or one lane is a lifetime's experience. In the world of poetic experience it is depth that counts, not width. A gap in a hedge, a smooth rock surfacing a narrow lane, a view of a woody meadow, the stream at the junction of four small fields - these are as much as a man can fully experience. ${ }^{4}$

Patrick McCabe's The Butcher Boy (1992), Roddy Doyle's Paddy Clark $\mathrm{Ha} \mathrm{Ha} \mathrm{Ha} \mathrm{(1993),} \mathrm{and} \mathrm{Seamus} \mathrm{Deane's} \mathrm{Reading} \mathrm{in} \mathrm{the} \mathrm{Dark} \mathrm{(1996),} \mathrm{are}$ all memoirs of sorts - Deane has said that his novel is 90 per cent autobiographical, Doyle addresses the life of a ten-year-old in Dublin in 1968 , when he himself was ten, and McCabe incorporated elements of his own upbringing in the small town of Clones into his tale. Similarly, all three writers engaged with particular places: Derry/Donegal, Dublin and Monaghan. The books under discussion are about boys dragged screaming into adolescence and young adulthood, perhaps prematurely. I want to take these texts as touchstones for a discussion around the extent to which the story of the Celtic Tiger is a Paper Tiger that conceals traces of struggles that persist into the present.

Some general remarks or propositions could be ventured about recent Irish fiction. Firstly, some maintain that, having for so long defined itself in relation to England, Irish literature is becoming 'Americanised' - postmodern, multicultural, late capitalist, postcolonial, globally marketed. Then the view is posited that the arrested development of modernism after partition having been broken, Irish writing is catching up with, and even overtaking, other national literatures. Finally, while it coincides with a resurgence of theory with a capital ' $T$ ' in Irish studies, this new fiction has arguably not been subjected to the kind of criticism that older or earlier authors such as Joyce and Yeats have enjoyed or endured; that as old certainties about the rights and wrongs of political struggle are thrown into doubt, what emerges are new ways of thinking about violence, and in particular ways in which violent language - vehement language - as well as obscuring the facts of history can accurately represent realities previously hidden, repressed, occulted, obscured. One question that arises from these claims

4 Patrick Kavanagh, cited in Peter Fallon and Derek Mahon (eds), The Penguin Book of Contemporary Irish Poetry (Harmondsworth: Penguin, 1990), p. xviii. 
to movement, advancement, progress, expansion, development, improvement and maturation is this: Why, if Irish fiction is coming of age, are its writers so obsessed with picking over the entrails of the past? There was a cartoon in the New York Times some years ago about a publishers' meeting at which a junior editor observed, 'Memoirs are so yesterday'. It's true, and some new Irish writers who appear to take their cue from Joyce are in fact closer to Yeats in their concern for the beauty that has passed from the world rather than that which is yet to come.

A lot of new Irish writers are first-generation professionals and graduates who went to good universities, got good degrees, may even have taught for a while, may still teach, yet who have, at least in their literary work, expressed a low regard for education, or rather for official forms of schooling. The fact that they had the benefit of a higher education explains, paradoxically, both their apparent anti-intellectualism or at least anti-establishment stance, as well as the reason they initially met with some resistance within the university. Some time ago, I met an American professor who works on Irish literature and particularly on Joyce. She was interested in my work, and mentioned a couple of male memoirs she thought were broadly in the same ballpark, Ciaran Carson's The Star Factory (1997) and Bernard MacLaverty's The Anatomy School (200I). As an afterthought, she added Frank McCourt's Angela's Ashes (1996) as another text worth looking at, if only to contrast the literary fiction with the more popular version of Irish childhood. Qualifying the term 'popular', she then told me that while in the United States Angela's Ashes was selling like hot cakes, in Ireland it was a hot potato, with people so angered by it they were taking it back to the bookshops in their hundreds. I'm not sure if they were doing so en masse or after Mass, but I assume they had read it first, and were merely economising (with the truth).

When I hatched the title for this essay I did so on the hoof, and it didn't occur to me till later how impertinent and presumptuous it was. To extrapolate from three texts by male authors, from Derry, Dublin and Monaghan, all charting the process of growing up in highly localised areas of Ireland in the 1950 s and 1960 s, seems absurd, not to say impossible. I suppose in my defence I could say I was seduced by an established rhetoric 
of growth and development, and by the fact that other critics were making grand claims from similarly small bases.

To suggest that something is now coming of age is an insult to what's gone before. Those of us who teach will have had the experience of claiming to be doing something new only to be rebuked by an older colleague who published the definitive essay on the topic thirty years ago. Or we might attribute something to our own period and thus betray our ignorance of earlier ones. So many things - self, nation and empire - appear to have their origins in the period in which we happen to have expertise. As well as being critically suspect, it is also politically problematic, and for a number of reasons. Revisionism, for example, the process of historical revision, suggests a re-reading, and an improvement upon an earlier draft. Like most discourses of progress or advancement it is questionable in the context of a colonial experience in which the coloniser was wont to represent native culture and traditions as backward, regressive, infantile. Claims to political maturity have gone hand-in-hand with discrimination and destruction. In the early modern period English colonists like Edmund Spenser represented Ireland as economically and culturally underdeveloped in order to justify its conquest and settlement. Critics such as Seamus Deane, Luke Gibbons and David Lloyd have taught us to be wary of Enlightenment narratives of progress that are complicit with empire and exclusion. Feminisation and infantilisation have been two strategies of colonialism, and since history repeats itself there's a risk that anti-colonial writings will fall into the trap of opposing through imitation, and thus merely mimicking.

But if claims that Irish writing is coming of age are premature or presumptuous then to insist that 'everything is already in Joyce' - as Derrida does $^{5}$ - is equally unfair on those writers following in his wake, and mapping out areas of experience - working-class rural experience, northern urban experience, female experience, queer experience, Gaelic experience - that have been abandoned, occulted, neglected or overlooked. What

$5 \quad$ Jacques Derrida, “'This Strange Institution Called Literature”: An Interview with Jacques Derrida', in Derek Attridge (ed.), Jacques Derrida: Acts of Literature (London: Routledge, 1992), pp. 33-75, p. 67. 
some (or much) recent Irish fiction shares with Joyce is a pronounced anticlericalism, or a virulent antipathy towards the Catholic Church. At least on the surface this appears to be the case. In an interview in the late 1990 , Frank McGuinness was asked if there was anything he could 'feel hopeful about at the end of the twentieth century'. McGuinness replied:

I think the Catholic Church having to become honest with itself, I think their having to grow up. And if it grows up, I hope a lot of its flock grows up as well. It's been hauled screaming into adolescence to be responsible for itself. There's hope in that all right. ${ }^{6}$

McGuinness was pressed further: 'You don't feel it's grown as far as it can grow?' This time his response was more frank:

Maybe it has actually. If it has grown as far as it can, then it's going to be left behind. Its failures now are so terrible, not just its sexual failures, which are so obvious, but its political failures as well, in the North, and in the South: social injustice here, the political war, the civil war in the North, which is propagated by its insistence on maintaining power in the schools. They've a lot to answer for. ${ }^{7}$

A lot to answer for indeed. Social injustice in the South, war in the North. That's a lot to lay at the door of the Catholic Church. Crucially, though, McGuinness goes on to distinguish between religion and spirituality, and between the Church as an institution and individual members who do good work. This is an important distinction - and a very Miltonic one whether or not it's wholly tenable. Some recent Irish fiction is intensely moral and spiritual, even pious and self-righteous, notwithstanding its opposition to official religion. A priest in Joyce's Portrait of the Artist declares 'that Victor Hugo had never written half so well when he had turned against the church as he had written when he was a catholic.'

6 Jacqueline Hurtley, 'Interview with Frank McGuinness', in Jacqueline Hurtley, Rosa Gonzáles, Inés Praga, and Esther Aliaga (eds), Ireland in Writing: Interviews with Writers and Academics (Amsterdam and Atlanta, GA: Rodopi Press, 1998), pp. 51-70, pp. 68-9.

7 Hurtley, 'Interview with Frank McGuinness', p. 69.

8 Harry Levin (ed.), The Essential James Joyce (St Albans: Granada, 1977), p. 29I. 
Later, Stephen's friend tells him a home truth: 'It is a curious thing, do you know, Cranly said dispassionately, how your mind is supersaturated with the religion in which you say you disbelieve.' This is true of a number of 'lapsed' Irish authors, who write like true priests of the imagination, though unlike the priest's opinion of Hugo they appear to have found inspiration in renunciation.

Roddy Doyle tells of an anonymous letter from a priest that ended with the line, 'We don't want you here, Mr Doyle. In your own words, fuck off!' This is not quite as bad as the newspaper photograph sent to the school where Doyle was teaching with another, more obscene four-letter word scrawled across his face and 'YOU'RE DEAD' written underneath. ${ }^{10}$ It could be argued that imitation is a form of flattery. It seems once you start using 'bad' or 'strong' language, once you start addressing violence or representing violence, then everyone wants to get in on the act. You can get caught up in the moment, the mayhem, and the madness. Doyle himself, speaking of The Woman Who Walked Into Doors (1996), said:

I felt quite exhilarated when I'd finished it. The pivotal chapter, which is the one about the first time she's hit - I was very excited and worked-up writing that chapter. It's ironic because it's horrible at one level but at the same time I felt that it was good, strong stuff. I was really quite happy about how I was doing it. ${ }^{11}$

Speaking of Doyle and his contemporaries, Gerry Smyth observes that 'Ireland itself has changed and grown, and it is perhaps no longer possible to offer a single artistic vision. ${ }^{12}$ I can't think of a vision more singular than that metaphor of growth, or one more problematic. Smyth goes further, and in a bold passage writes:

Doyle, like many of the most innovative and challenging of contemporary Irish novelists, grew up during the 1960 s, when Ireland was undergoing an intense renegotiation

9 Levin, The Essential James Joyce, p. 355.

Io Roddy Doyle, 'What's the Story?, in Hot Press 20:6 (1996), pp. I8-20, p. I8.

II Doyle, 'What's the Story?', p. I8.

I2 Gerry Smyth, The Novel and the Nation: Studies in the New Irish Fiction (Dublin: Pluto Press, 1997), pp. 66-7. 
of its identity and role in the world. From being a backward-looking and isolationist nation, Ireland moved to embrace the modern world - socially, economically, culturally. The pace of these changes, given the long years of stagnation which preceded them, seemed all the more unsettling to many Irish people. The world, if not turned upside down, was certainly revolving faster than it had for many years and while some welcomed the belated onset of the twentieth century, others feared the consequences of the clash between established practices and what had traditionally been represented as 'alien' ideas. ${ }^{13}$

Leaving aside questions of cosmology and geology, Smyth's certainty that Ireland was backward-looking before the belated onset of the twentieth century is at odds with his analysis of Paddy Clarke and The Butcher Boy: 'Both stories are narrated by young males, and one of the shared themes is the dangerous discrepancy between physical, psychological and emotional maturity.' ${ }^{14}$ If there is a 'dangerous discrepancy between physical, psychological and emotional maturity', why should political and cultural or literary maturity be as in step as Smyth implies? To speak of a 'process whereby a young, highly educated, post-nationalist community began to interrogate the discourses which had structured modern Ireland' is I think to move a little too quickly. ${ }^{15}$ To begin to interrogate something is not the same as being beyond or above it. In fact this transcendental state is rather close to the thing it wants to move beyond.

Paddy Clarke is a novel full of growing pains. At one point, Francis, Paddy's younger brother, also known as Sinbad, is crying in bed, and Paddy tells his parents. His mother goes upstairs:

- Ah, what's wrong, Francis?

She didn't say it like What's wrong this time.

- I've a pain in my legs, Sinbad told her.

His rhythm was breaking down: she'd come.

- What sort of pain?

- A bad one.

- In both your legs?

I3 Smyth, The Novel and the Nation, p. 79.

I4 Smyth, The Novel and the Nation, p. 82.

is Smyth, The Novel and the Nation, p. 80. 
- Yeah.

- Two pains.

- Yeah.

She was rubbing his face, not his legs.

- Like the last time.

- Yeah.

- That's terrible; you poor thing.

Sinbad got a whimper out.

- That's you growing up, you know, she told him.

- You'll be very tall.

I never got pains in my legs.

- Very tall. That'll be great, won't it? Great for robbing apples. That was brilliant.

We laughed.

- Is it going now? she asked him.

- I think so.

- Good. - Tall and handsome. Very handsome. Ladykillers. Both of you.

When I opened my eyes again she was still there. Sinbad was asleep; I could hear him. $^{16}$

Pains in the legs and in the legacy that are imprecise. Maybe Irish fiction is growing the way that Sinbad is growing? Later, Paddy's mother is helping him get dressed for school:

- You're getting very tall, she said.

She was trying to get the zip of my trousers to close.

- You'll soon be the same size as your daddy.

I wanted that, to be the same size as my da. My name was the same as his one. I'd waited till he'd gone to work before I'd shown her that the zip wouldn't shut properly. He'd have shut it. I hoped she wouldn't be able to do it. I hated the trousers. They were yellow corduroy. One of my cousins had owned them first. They'd never been mine.

She hitched them up. She tried to hold the two sides together so the zip would go up. I didn't cheat. I even sucked in my belly.

- No, she said. - No use.

She let go of the trousers.

- They're finished, she said. - You're growing too fast, Patrick.

I6 Roddy Doyle, Paddy Clarke Ha Ha Ha (London: Secker and Warburg, 1993), p. 66. 
She didn't mean it.

- We'll have to use a safety pin, she said.

She saw my face.

- Just for today. ${ }^{17}$

Again, Paddy's predicament might reflect the larger difficulty of contemporary fiction. It wants to be the same size as its father, and to get rid of those borrowed clothes, but it's still relying on hand-me-downs. At the end of the novel, Paddy predicts that his mother will say to him, in response to his father leaving: 'You're the man of the house now, Patrick', to which Paddy thinks in reply, 'That was the way it always happened. ${ }^{18}$

Something happened to Irish literature, or so the story goes - and grows. To use an Americanism, it just growed - sexually, socially, spiritually, internationally, in terms of class, gender, generation and global import. One of the ways it has growed or grown is arguably in the representation of violence, political and 'domestic'. In response to his father slapping his mother Paddy thinks:

He'd hit her. Across the face; smack. I tried to imagine it. It didn't make sense. I'd heard it; he'd hit her. She'd come out of the kitchen, straight up to their bedroom. Across the face ...

I loved him. He was my da. It didn't make sense. She was my ma. ${ }^{19}$

This ambivalence is carried over into Doyle's next novel, The Woman Who Walked Into Doors, a sustained treatment of male violence against women, where Paula says of Charlo: 'He loved me and he beat me. I loved him so I took it. It's as simple as that, and as stupid and as complicated. I keep on thinking and I'll never come to a tidy endin.' ${ }^{20}$

17 Doyle, Paddy Clarke, pp. 96-7.

I8 Doyle, Paddy Clarke, p. 28I.

19 Doyle, Paddy Clarke, pp. 190-I.

20 Roddy Doyle, The Woman Who Walked Into Doors (London: Jonathan Cape, 1996), p. 192. 
A refusal to take sides or to simply condemn or condone violence is a feature of contemporary Irish fiction. The most compelling and controversial instance is arguably Patrick McCabe's The Butcher Boy. In a perceptive review of Neil Jordan's 1997 film version Charlotte O'Sullivan writes:

Francie murders his well-off neighbour, Mrs Nugent, shooting her in the head with a butcher's stun gun then cutting open her body so he can smear the walls with her blood. Do we come to understand why he does it? Yes, we do. In Jordan's idiosyncratic take on Patrick McCabe's acclaimed novel, the child's violence is made to seem positively desirable. $^{21}$

O'Sullivan argues that Jordan's 'not-so-hidden agenda' is 'defining a new sort of morality, one to which violence is the key. ${ }^{22}$ Mrs Nugent (in the film) is a 'blood sacrifice' in the familiar tradition that says without the shedding of blood there can be no redemption. We are back with Pearse. O'Sullivan's reading of the book and the film lead her to conclude that while 'McCabe's story is a tragedy with many victims - a study of a world in which terrible things happen, deserved or not. In Jordan's The Butcher Boy, the world deserves everything it gets. ${ }^{23}$ O'Sullivan maintains that:

the view of Ireland on offer here is one the world (particularly America) finds comforting. Like Frank McCourt's Pulitzer Prize-winning novel Angela's Ashes, Jordan's film offers a dirt-poor Ireland, befuddled and priest-ridden, full of drunken, proud and feckless fathers with put-upon and irresponsible wives. In this way it comes very close to confirming the 'bog-man' stereotypes that torture (he never forgets Mrs Nugent calling him a pig) and structure Francie's imagination. ${ }^{24}$

The opposition that O’Sullivan sees Jordan setting up - innocent Francie versus complicit Ireland ${ }^{25}$ - is arguably the central tension of McCabe's

21 Charlotte O'Sullivan, 'Massacre of the Innocents', in Sight and Sound 7:3 (1998), pp. IO-I3, p. II.

22 O'Sullivan, 'Massacre of the Innocents', pp. II-I2.

23 O'Sullivan, 'Massacre of the Innocents', p. I2.

24 O'Sullivan, 'Massacre of the Innocents', p. I3.

25 O'Sullivan, 'Massacre of the Innocents', p. I3. 
novel, which is after all the sympathetic portrayal of a young boy who kills a middle-aged woman. O’Sullivan ends: 'Be like Francie, says Jordan, you have nothing to lose - fight back! ${ }^{26}$

But is it just Jordan, or is McCabe in on the deal? Their close collaboration on the screenplay suggests a shared vision, and other critics have viewed the novel and film as doing similar things:

This is a full-frontal attack on the bulwarks of conservative Irish society, and no mercy is shown. The agrarian culture, core of de Valera's ideal, is derided in the form of the 'bogmen', gangly big-eared narrow-eyed idiots who suck their porridge out of the air having flung it in the direction of the face with a kind of waterwheel motion of the spoon. The townspeople (although more civilised) are backstabbing dull conformists - all in contrast to Francie who, though homicidal, at least has a spark of creativity and a sense of humour. Jordan and McCabe, in the person of Francie, are dancing on the grave of Mrs Nugent, an icon for the old way of being Irish, and her culture - sanctimoniously pious, introverted, hypocritical, dead. ${ }^{27}$

Talk about violent language. These are strong words indeed, and problematic too. The old Ireland, the one that hasn't come of age, was depicted as a woman, and the new is also figured as female, as a woman (Mrs Nugent = 'new gent'). That leaves the problem of why Francie's fury is directed towards the mother of the boy who has taken away his best friend, why she gets the blame and the butchery. Despite what O'Sullivan says about Neil Jordan inflecting or deflecting the violence of the novel in his film adaptation there's a very real sense in which the novel already contains a justification of violence and a displacement of aggression and resentment onto a woman. Class is what it's all about on one level, but class is gendered in the form of the upwardly mobile, house-proud town mouse, Mrs Nugent. Mr Nugent is away on business a lot and doesn't really come into

26 O’Sullivan, 'Massacre of the Innocents', p. I3.

27 Terry Byrne, 'Review of Neil Jordan, The Butcher Boy', in Irish Studies Review 6: 2 (1998), pp. 227-9, pp. 228-9. 
it. Since the days of Spenser and Swift the figure of woman has been the site of colonialist and nationalist anxiety. ${ }^{28}$

Speaking of his own life Patrick McCabe has said it was:

I suppose outwardly quite normal, like any ordinary family, but inwardly - fireworks, catastrophic domestic stuff and all that. Certainly there was no such thing as an ordinary family so I would say I was born into an extraordinary, ordinary family. My parents were small town, working class, I suppose, poorly schooled but highly educated, surrounded by books, music, all that sort of thing. And because you're born into a small town your life is interwoven all the time with people; it is never divorced from people. So any time I approached fiction it always had to have the heartbeat of humanity in there for it to work. That was always why I was attracted to Joyce. Although people say he was cold, I've never found Bloom remotely cold, or any of the stuff in Dubliners. ${ }^{29}$

There's a book to be written on slaughterhouses in Irish literature: Memoirs of the Abattoir. According to McCabe: 'you encounter brutality at a very early age, anybody growing up in a small town does. I particularly did because the abattoir was beside the house. ${ }^{30}$ Asked whether he subscribed to Joyce's artistic principle, his refusal to serve, 'Non Serviam', McCabe replies:

I think the whole Joycean thing about Non Serviam, I mean you became aware at an early age that that belongs to a certain time. You'd actually get embarrassed if you said to someone 'I will not serve'. They'd laugh their heads off. 'You're what? Non Serviam. Yeah, sure, yeah ... good luck'. Because nobody cares, people were coming and going out of the country anyway. Non Serviam when people are flying across the

28 See for example Elizabeth Butler Cullingford, “'Thinking of Her ... as ... Ireland”: Yeats, Pearse and Heaney', Textual Practice 4:I (1990), pp. I-2I; Sabina Sharkey, 'Gendering Inequalities: The Case of Irish Women', Paragraph I6:I (1993), pp. 5-22.

29 Patrick McCabe, interviewed by Christopher FitzSimon, 'St Macartan, Minnie the Minx and Mondo Movies: Elliptical Peregrinations Through the Subconscious of a Monaghan Writer Traumatised by Cows and the Brilliance of James Joyce', in Irish University Review 28:I (1998), pp. 175-89, p. 177.

McCabe, 'St Macartan, Minnie the Minx and Mondo Movies', p. I84. 
world right left and centre, you'd just be the village idiot wouldn't you? 'Oh there's Non Serviam up there again! I suppose he's writing a few books! ${ }^{31}$

But how much has changed? What Raymond Williams says of Synge and O'Casey could be said of Doyle and McCabe:

What the writers found, in their own medium, was 'richness', but the richness was a function of a more pressing poverty, and this was at times idealized, at times compounded ... But the most interesting later work is where the interest always was: in the true nature of that endless fantasy of Irish talk. ${ }^{32}$

The orality, the articulacy, the comedy, the craic, stands in for an absence - political, social, economic, an emptiness and a burning at the heart of Irish culture, but it also speaks to an exclusion that the language assuages and assails.

There are three powerful images that the novels of Deane, Doyle and McCabe share. One is of being trapped, literally locked into the land. Another is of flight or disappearance (often frustrated, thwarted, disappointed). A third is that of exclusion, and of being excluded at home, either literally at home, in one's house, or in one's heartland, one's community or home town, of being alienated, ostracised, foreign in a familiar place. In Paddy Clarke Ha Ha Ha there's Paddy's hideaway in the pipe and his desire to run away before his father beats him to it. In The Butcher Boy Francie has a hideout too, and he's also Francie Pig - how much closer to the land can you get? But he has another name, his 'Indian' name, given when he and Joe become Blood Brothers. He is Bird Who Soars. In Reading in the Dark the narrator is shut in the fort at Grianan by his friends - they roll the stone over the entrance and enclose him in darkness. This episode comes immediately after one entitled 'The Field of the Disappeared', when the narrator's father takes him to a place near the cliff's edge that swallowed people and birds.

3I McCabe, 'St Macartan, Minnie the Minx and Mondo Movies', p. I85.

32 Raymond Williams, Drama from Ibsen to Brecht (Harmondsworth: Pelican, 198I). p. 148 , p. 169 . 
The passages I've selected, though, are about exclusion, rather than entrapment or escape. I think the consequences and implications of exclusion play a large part in recent Irish fiction, exemplified in these three novels. When Francie attacks Philip Nugent with a chain and his friend Joe restrains him, Francie feels as though: 'I was standing with my back against the wall it felt as if I was on a cliff edge. ${ }^{33}$ Characters with their backs to the land, the wall, a cliff edge, characters like Joyce's Eveline, abused at home yet fearful of leaving, such characters people this 'new' fiction. The three passages I've selected from the three novels depict moments when the characters are aware of being left out in the cold, looking through windows into interiors denied them. First, Paddy Clarke, stranded at the door of a local Protestant lad, Alan Baxter, the only boy in Barrytown to own a Scalextric electric train set, a coveted toy. ${ }^{34}$ Next, Francie Brady, admiring through the window the cosy home of the Nugents - new gents indeed with its 'butter dish with a special knife, a bluestriped jug with matching cups, all these things they had. It was as if just by being the Nugents it all came together as if by magic not a thing out of place. ${ }^{35}$ The only thing out of place is Francie.

That blue and white jug and with it a mother and son waiting for a father to return from work crops up again in Reading in the Dark. The narrator has written an essay full of high-flown nationalist rhetoric, drawn from old nationalist literature. His English teacher reads an essay aloud as an example of writing as it should be, 'just telling the truth. ${ }^{36}$ This essay - by a country boy, someone like Seamus Heaney, who was a classmate of Deane's - makes the narrator feel embarrassed, but at the same time he feels something else. He feels that the truth lies somewhere in between and that something is left out of this 'true' story, something is excluded, haunting the domestic scene:

34 Doyle, Paddy Clarke, p. I13.

35 McCabe, The Butcher Boy, p. 44.

36 Seamus Deane, Reading in the Dark (London: Jonathan Cape, 1996), p. 21. 
And yet I kept remembering that mother and son waiting in the Dutch interior of that essay, with the jug of milk and the butter on the table, while behind and above them were those wispy, shawly figures from the rebellion, sibilant above the great fire and below the aching, high wind. ${ }^{37}$

This passage, part of the title chapter of Reading in the Dark, captures beautifully the dilemma of recent Irish fiction, the dilemma of local truth or integrity and of inclusiveness, of awareness of a larger political context. I think Deane's is arguably the most subtle and searching exploration of these issues, but Doyle and McCabe have their moments too. A key question that arises in considering issues of exclusion and representation is the matter of the local versus - or voices? - the global. According to Keith Booker:

Doyle's work as a whole calls attention to the global spread of American popular culture in a striking way, but the very prominence of this culture in the work of an Irish writer also suggests that 'American popular culture' is something of a misnomer and that what is really involved is the popular culture of multinational capitalism. ${ }^{38}$

There are allusions to world events in the novels under discussion here, including Paddy's family watching the Vietnam war unfold on their TV screen; Francie hearing of Khrushchev's threat and the Cuban missile crisis; and Deane's protagonist dwelling on whether the global maters more than the local. Doyle certainly feels that his work filled a gap site in public life. He says:

I wrote The Commitments because there are probably a million people living in the suburbs in Dublin who did not exist in TV content or literature. I am a social democrat. I believe in the equality of all people. I reject the idea that the small world is less important than the world of leaders. I think that the ignored life is fascinating. ${ }^{39}$

37 Deane, Reading in the Dark, p. 21.

38 M. Keith Booker, 'Late Capitalism Comes to Dublin: "American” Popular Culture in the Novels of Roddy Doyle', in ARIEL 28 (1997), pp. 27-45, p. 33.

39 Roddy Doyle, interview in The Big Issue (Ireland) 40, 21 March-3 April 1996, p. 23. 
The small world, the ignored life - this is the setting and subject of the new local and international - rather than national - Irish literature. It brings to light places - of the land and of the mind - hitherto veiled, vanished, vanquished or voiceless. McCabe asks: 'If you haven't known disappointment, or if you haven't known exile, can you do any of these things ? ${ }^{30} \mathrm{How}$ can writers and readers connect with the occulted elements of a culture? According to Jacques Derrida:

One of the most necessary gestures of a deconstructive understanding of history consists ... in transforming things by exhibiting writings, genres, textual strata (which is also to say - since there is no outside-the-text, right - exhibiting institutional, economic, political, pulsive [and so on] 'realities') that have been repulsed, repressed, devalorized, minoritized, deligitimated, occulted by hegemonic canons, in short, all that which certain forces have attempted to melt down into the anonymous mass of an unrecognisable culture, to '(bio)degrade' in the common compost of a memory said to be living and organic. ${ }^{41}$

There is also the matter of knowing and dealing with disappointment. Paddy Clarke, towards the end of Doyle's novel, climbs into the cupboard to conquer his fear of the dark: 'The dark was the only thing to beat, and I'd beaten it. It didn't scare me a bit. I liked it. It was a sign of growing up, when the dark made no more difference to you than the day. ${ }^{42}$ All these novels are about reading in the dark, and in that respect they all owe a debt to John McGahern's pioneering novel, The Dark, published to much outrage in 1965: 'Say what you said because I know. ${ }^{\text {'3 }}$ If the Enlightenment was merely one way in which British imperialists rationalised what they were doing then perhaps what we're seeing is an 'Endarkenment', a movement beyond the pale, into hidden recesses, dim corners, hideaways, underground passages and secret stairways, hung with shadows. These writers know the good that can come out of the dark.

40 McCabe, 'St Macartan, Minnie the Minx and Mondo Movies', p. I86.

4I Jacques Derrida, 'Biodegradables: Seven Diary Fragments', trans. Peggy Kamuf, Critical Inquiry 15:4 (1989), pp. 812-73, p. 821.

42 Doyle, Paddy Clarke, p. 278.

43 John McGahern, The Dark (London: Faber, 1965; 1983), p. 7. 
The most powerful passage to my mind in Reading in the Dark occurs in the chapter entitled 'The Roses', when the son destroys the rose bushes in defiance of the father, the desecration of the garden, the destruction of a pastoral retreat, first rehearsed as a poem by Deane. There are shades of Alice Munro's short story 'Vandals', the closing tale of the collection Open Secrets (1995). ${ }^{44}$ Violence has a history, vandalism a context. Without the shedding of buds there can be no redemption, and without that scene the subsequent cry of love would not carry the same weight:

He went upstairs. He never took a drink in his life. I've reconstructed his vigil behind the door in that noisy room a hundred times since, just as I reconstructed his life out of the remains of the stories about his dead parents, his vanished older brother, his own unknowing and, to me, beloved silence. Oh, father. ${ }^{45}$

Children who have outgrown their parents can still acknowledge a debt, a burden, and devotion. Coming of age can entail a reconciliation rather than - as well as - a rejection, renunciation or refutation.

The purpose of this chapter has been to suggest that we ought not to be too hasty in our efforts to be done with the past. I wanted to sound a note of caution - especially in light of current world events - against what I see as an over-optimistic attitude to globalisation. I'm interested in the sleeve-tugging and shoulder-tapping elements that can be found in fiction and which take the long view, back as well as forward. The three writers discussed here have offered backward looks that are arguably more nuanced and subtle than some of the celebrations of postnationalism and pluralism that have accompanied the era of globalisation. As I put the finishing touches to this essay, two items appeared in The Guardian newspaper that dovetailed neatly with my theme of premature overdevelopment and the pitfalls of a complacent and complicit narrative of progress. One item concerned a village in India where environmental changes are creating 'tiger widows', as the animals are forced to forage for food closer to humans. As part of a ploy to evade the tigers, villagers took to entering

44 Alice Munro, Open Secrets (London: Vintage, 1994; 1995).

45 Deane, Reading in the Dark, p. 226. 
the forest wearing a mask on the backs of their heads, as tigers only attack from behind. Unfortunately, this ruse didn't fool the tigers for long. ${ }^{46} \mathrm{The}$ next day another item, this time a financial rather than environmental story, announced that Ireland, the much-vaunted 'Celtic Tiger', had gone into recession. Clearly the mask worn back-to-front isn't working there either, and tiger widows and orphans will be the order of the day. ${ }^{47}$ The time of literature is different from that of history or economics, but Irish fiction that addresses the complexities of coming-of-age stories can help make us more aware of the hidden agendas and false faces of those who wish to reassure us that we are all heading in the same and the right direction. Gerry Smyth's confident assertion - 'From being a backward-looking and isolationist nation, Ireland moved to embrace the modern world - socially, economically, culturally' - appears less credible in this light. ${ }^{48}$ There is much to be said for the backward look, especially when there are fat cats on the prowl.

46 'There are many Tiger Widows here', http://www.guardian.co.uk/environment/2008/ sep/25/conservation.climatechange (accessed 27 September 2008).

47 'Ireland is First to Slip into Recession', http://www.guardian.co.uk/world/2008/ sep/26/ireland.globaleconomy (accessed 27 September 2008).

48 Smyth, The Novel and the Nation, p. 79. 



\section{II. 'The Universal is the Local without Walls': John McGahern and the Global Project}

EAMON MAHER

John McGahern (1934-2006) has long been considered a writer who was rooted in a very specific place - the northwest midlands around Leitrim and Roscommon - as well as someone with a finely attuned understanding of the rural communities who inhabit this area. The idea of his work being included in a book on globalisation and culture might initially seem inappropriate. After all, he did not concern himself excessively with the emergence of the Celtic Tiger, other than to say that he thought the newly found prosperity was wonderful: instead of seeing generations leaving Ireland to seek work abroad, it was pleasant to know that there were ample opportunities for young people to stay and work in their country of birth. The spin-offs of globalisation such as immigration, the arrival of multinational companies, global capital flows, increased opportunities for travel, the internet, full employment, improved GNP and GDP, did not impact on his characters to any great extent, mainly because he wrote about communities who tended to live at a temporal and geographical remove from this sort of thing. Getting livestock to the fair, saving the hay, interacting with family and friends, attending Mass and religious services, facing up to the prospect of death, these are the main preoccupations of the characters we encounter in McGahern's novels and short stories.

What I will seek to demonstrate in the course of this chapter is that his concentration on the local did not prevent McGahern from achieving a global resonance, that it assisted him, in fact, to give a universal dimension to his work. In an interview in 2000 , he quoted the Portuguese writer Miguel Torga, who in the sixth volume of The Creation of the World wrote: 
'The universal is the local without walls.' I consider this a good description of McGahern's main literary achievement: he managed to make of one small place an everywhere. Like a Renaissance painter, he was constantly perfecting his canvas with fine brush strokes, attaining near the end of his life something approaching perfection.

One thing that has often struck me is the extent to which McGahern tended to quote international writers when it came to citing influences. Yes, there were the Irish reference points like Joyce, Beckett, Tomás O'Crohan, Patrick Kavanagh, Ernie O'Malley, Kate O'Brien and Michael MacLaverty to name a few, but interspersed with these names was a host of internationally renowned figures such as Proust, Flaubert, Camus, Thomas Hardy, Tolstoy, Chekhov and Alisdair MacLeod, who all displayed qualities that McGahern was seeking to emulate in his own work. In this regard a comment by Jane Austen, another influence, is significant. In a letter she wrote describing the inspiration for her work, Austen spoke of 'the little bit (two Inches wide) of Ivory on which I work with so fine a Brush, as produces little effect after much labour.' This sums up McGahern's approach very well. He was painstaking in his attempts to evoke the right sounds, smells, colours and impressions connected with his 'little bit of Ivory.' He sculpted and re-sculpted his words until they captured the correct rhythm, the authentic voice, the exact image. Now that a few years have elapsed since his untimely death in 2006 , critics are coming to terms with his legacy and discovering that he was essentially a writer with a keen sense of place, an appreciation of the glory of nature, a close identification with, and admiration for, local characters and their foibles. Ultimately, his great ability was to move seamlessly from the local to the global.

It is worth considering for a while the Ireland in which McGahern grew up and that he mined for his fictional creations. The r930s and 1940 s were

I McGahern and Torga (who is referred to as Torja) are actually misquoted in the tapescript of the interview, which was published as 'Catholicism and National Identity in the Works of John McGahern', in Studies: An Irish Quarterly Review, 90:357, Spring 200I, pp. 70-83, p. 8I.

2 Deirdre Le Faye (ed.), Jane Austen's Letters (Oxford: Oxford University Press, 3rd edn, 1995). Earlier editions were edited by R.W. Chapman. 
decades when the fledging Irish Free State, later to become a Republic, was attempting to come to terms with its newly found freedom from British rule as well as the aftermath of a bitter Civil War which had left deep scars and divisions. Emigration reached epidemic proportions during these years and McGahern saw many of the young men who attended his primary school having to leave Ireland in order to make a living in Britain or the United States. He wrote in the following manner about the i950s:

There were two sectarian states in place in the 1950s, North and South, inward-looking and ostensibly secure, secretly content with one another, despite public claims and utterances. Each could point the other out in self-justification. [...] In the South individual speech and thought were equally discouraged. The moral climate can be glimpsed in the warning catchphrases: A shut mouth catches no flies; Whatever you say, say nothing; Think what you say, but don't say what you think; The less you say, the more you'll hear; Mind you, I have said nothing. ${ }^{3}$

The moral climate was obviously as depressing as the economic one south of the border, yet there were signs of a loosening of the absolute control exercised by the Catholic Church. ${ }^{4}$ People did not live in Ireland at the time, according to McGahern. Rather, they lived in 'small, intense communities, and the communities could vary greatly in spirit and character, even over a distance of a few miles.' Within these communities were mini-republics, where the real power lay - the families. McGahern understood the structures of the Irish society that moulded him. He disliked the repressive nature of authoritarian Catholicism and yet appreciated the beauty of its rituals. He resented the violence that characterised many family situations, the bullying fathers and the pious, accepting mothers,

3 John McGahern, 'Whatever you say, say nothing', in The Irish Times, 26 October 1999, p. 13.

4 While it may have appeared in 1951, with the resignation of Dr Noel Browne after his failure to secure party support for his controversial mother-and-child scheme, that the church was rarely more in the ascendant, there is a sense in which this event marked the beginning of the end of this type of successful church interference in state affairs.

McGahern, 'Whatever you say, say nothing'. 
yet knew that the bonds of place and family were an essential part of the fabric that held society together. Irish emigrants, for example, could never look on their new abodes in London, Liverpool, Boston or New York as being real somehow and they resented the fact that they had been forced to uproot themselves from their homes in Ireland. There had been evidence of much transformation in the course of the decade, as McGahern notes at the end of his Irish Times article:

I think of the decade beginning with the lighting of the paraffin lamps as darkness came on, the polishing of the globe, the trimming of the wicks, the adjustment of the flame, as it had been done for generations. By the end of the decade every house had electricity. Most people had radios, very soon they would all have television. The world that had stayed closed and certain for so long would soon see nothing but change. ${ }^{6}$

When assessing the impact of globalisation on Irish society in recent decades, much is made of the negative effect it has had on the notion of belonging to a community, on religious practice or involvement in charitable organisations: in essence, it appeared to bring with it a blurring of national boundaries and identity, as Irish society came to resemble more closely the experience of the countries of mainland Europe. For McGahern and his generation, the fifteen-odd years of economic boom that began in the 1990 s was not much more than the second playing of a drama that had occurred during the 1960s, another decade of seismic upheaval in Irish life. His own literary career began with the publication of The Barracks in 1963 and continued until his death in 2006. In effect, therefore, it coincided with two major periods of change and evolution. Air travel, the widespread availability of the motor car, television, building booms, sexual liberation, the Women's Rights movement, Ireland's entry to the EEC, the internet, political and clerical scandals, the legalisation of contraception and divorce - all these events and many more took place during McGahern's career. However, he is seen as a writer who, while being about every house having electricity at the end of the i950s would stand up to scrutiny, but I think that the point he makes about change is valid. 
aware of the transformations that were happening all around him, decided to concentrate on certain immutable truths, on situations where there was evidence of resistance to change, where, in fact, very little changed at all. Towards the end of The Pornographer, as he is driving back to Dublin after the funeral of his aunt, the nameless narrator's boss Maloney notes how his friend's uncle, who returns to work in his saw mill the day after his sister's funeral, is someone who has figured out the key to happiness: 'There's one man who knows he's going everywhere by staying put." As we now begin to assess some of McGahern's fiction in the light of what it brings to our understanding of his engagement with the global project, I think that Maloney's assessment is apposite. Knowledge is not merely dependent on education, travel or technology: it can also be achieved while living an uncomplicated life in a community that cares more for what is happening in its immediate environs than events, however momentous, taking place a mile down the road. David Pierce shows a genuine understanding of McGahern's literary goal when he observes that 'he [McGahern] relies for the most part on the iterative mode where things gather meaning with repetition and where the larger frame of ritual, or the seasons, or family history, informs or obtrudes. ${ }^{8}$

McGahern was undoubtedly cognisant of the profound changes that took place in Ireland during his lifetime: how, for example, the International Financial Services Centre and Temple Bar became the symbols of a new vibrant Ireland during the 1990 s and the early years of the new millennium. But his literary canvas was not composed of the fast-moving milieu of material prosperity, flash cars, casual sex, recreational drugs and plentiful money that these places came to represent. Rather, it was one in which change came into being in a much more leisurely and imperceptible manner. His fictions clearly do not reflect the Celtic Tiger era, which is not to say that he chose to ignore its existence: it was just a case of his knowing

7 John McGahern, The Pornographer (London: Faber, 1979), p. 250. All subsequent references will be to this edition, with page numbers in parentheses.

8 David Pierce, Light, Freedom and Song: A Cultural History of Irish Writing (New Haven and London: Yale University Press, 2005), p. 280. 
that the people and places which best suited his particular esthetic were situated west of the Shannon and were sometimes gloriously unaware of what was going on in their capital city and elsewhere. Certain critics took issue with the rather depressing image of Ireland presented in his earlier fiction and others complained at how his last novel, That They May Face the Rising Sun, was too tranquil in its representation of an idealised rural Ireland. McGahern was no stranger to controversy in his early career. His second novel, The Dark (1965), courageously tackled taboo subjects like masturbation, sexual abuse and violence in the home - as well as hinting at clerical child abuse - a move which cost him his job as a primary-school teacher in Clontarf. Effecting social change was not how he saw his role as a writer, however. He stated in an interview (August 2002):

If a writer only sets out to reflect a particular society he will only be of interest to a historian or a sociologist. What is permanent is the spirit or personality in language, the style, and that's what lasts. A book that was written two hundred years ago can be as alive today as when it was first published, and last month's novel can be as dead in a year as a laboratory mouse. I do think that if a person gets his words right that he will reflect many things; but if he sets out deliberately to do it, he'll be writing journalism. ${ }^{9}$

McGahern could never be accused of writing journalism. His objective was not to instruct or be didactic: he just wanted to paint a realistic picture of the Ireland he knew and in so doing capture some universal truths. In the first example of his fiction to which we now turn, the short story 'A Country Funeral', we will see how the journey back to the place where they were forced to travel from Dublin to spend every summer on their uncle's farm evokes strange feelings in three brothers. The news that their uncle Peter has died means that Fonsie, Philly and John Ryan have to travel west in a hired Mercedes (Philly works on the oil rigs and makes good money, most of which he wastes buying drinks for people in their Dublin local during his visits home). As far as the invalided Fonsie is concerned, their uncle Peter was a horrible man who made them feel unwelcome in his home. Philly

9 'Interview with John McGahern', in Eamon Maher, John McGahern: From the Local to the Universal (Dublin: The Liffey Press, 2003), pp. I43-6I, p. I45. 
and John, a married teacher, do not harbour the same degree of rancour as their brother. As they prepare to get into the car and head to the funeral, their mother warns: 'Everything you do down there will be watched and gone over. I'll be following poor Peter in my mind until you rest him with Father and Mother in Killeelan (cemetery). ${ }^{{ }^{10}}$

What is strange about their journey is the extent to which the three men get sucked into the life of their uncle, for whom they had no great affection, as well as coming under the spell of the community to which he belonged. Because they are the only family he had, the brothers must look after the funeral arrangements and meet the people from the surrounding area. McGahern knew the significance of a funeral in rural Ireland. It is not simply a question of putting a corpse in a coffin and burying it. No, certain rituals must be obeyed: food and drink bought for the wake; a full discussion and appraisal of the man's life up until his death; the funeral Mass and the laying to rest of the body. The same rituals have been observed for centuries and must be strictly adhered to. There is a sense in which the landscape around Gloria Bog where their uncle lived is transforming the men without their realising it. The idea of journeying towards self-knowledge is strong in McGahern, for whom life was a never-ending quest. Note how it is important that the Ryans get out of Dublin before they can really discuss things:

Not until they got past Leixlip, and fields and trees and hedges started to be scattered between the new raw estates, did they begin to talk, and all their talk circled about the man they were going to bury, their mother's brother, their Uncle Peter McDermott. (p. 374)

Similarly, beyond Carrick-on-Shannon, they begin to remember certain sights from their youth: 'They were coming into country they knew. They had suffered here' (p. 377). The memories that come flooding back are not pleasant, especially for Fonsie: 'The man wasn't civilized. I always felt if he Stories (London: Faber, 2006), pp. 373-4. All subsequent references will be to this edition, with page numbers in parentheses. 
got a chance, he'd have put me in a bag with a stone and thrown me in a bog hole like that black whippet' (p. 378). When they arrive at Peter's house, they are greeted by his neighbour Jim Cullen and a few other people who stand up and offer their condolences. Their uncle is laid out on the bed and already Mrs Cullen has been busy making tea and sandwiches. Then the testimonies to the dead man's life and character begin:

'You couldn't have a better neighbour. If he saw you coming looking for help he'd drop whatever he was doing and swear black and blue that he was doing nothing at all', an old man said. (p. 379)

Jim Cullen discreetly shows them the bill for the food and drink he has bought and informs them of the wad of notes that was in Peter's wallet. Every effort is made to let the brothers know exactly what is expected of them. When it looks like all three are going to head to the village, it is suggested that it might be as well if one stayed in case of callers. Mrs Cullen then volunteers to sit with John, who is amenable to greeting visitors in the house but who would know very few of them. Fonsie is bursting with resentment as he and Philly drive to town. He senses that Philly, to whom he is close, is impressed at the way the locals support one another in their time of need. Fonsie says it is all 'barbaric, uncivilized, obscene', that they should not have come. He refuses to accompany his brother into Henry's bar-grocery, where the proprietor insists that Philly have a drink on the house. On their way back to their uncle's, the car laden with food and drink for the wake, Philly stops to look at Gloria Bog. Already the idea is taking shape that this could be the place for him to settle after he has finished on the rigs.

The three brothers are quite different in temperament. John is easygoing, full of charm and good manners. He refused the headship of the school where he was teaching, a fact that greatly displeased his ambitious wife. Philly is more extrovert, though perhaps not as natural a mixer. He accepts the condolences of the mourners and answers them with the customary phrases: 'Thank you for coming. You're very good.' Fonsie is a ball of fuming anger in his wheelchair, constantly ready to find fault with those coming to pay their respects. His hatred of his uncle cannot be assuaged, 
even beyond the grave. Philly decides to spend the night of the removal in Peter's house, where he briefly looks through his affairs. There are thousands of pounds in his wallet, along with dollars and receipts - all remnants of a solitary life on a small farm. Peter had been fond of making animals out of matchsticks in the candlelight, an image that for Philly captures the pointlessness of his life:

Tomorrow he'd lie in the earth on the top of Kelleelan Hill. A man is born. He dies. Where he himself stood now on the point between those two points could not be known. He felt as much like the child that came each summer years ago to this bog from the city as the rough unfinished man he knew himself to be in the eyes of others, but feelings had nothing to do with it. He must be already well out past halfway. (p. 395)

The winding path up to the cemetery (Killeelan) was treacherous for those carrying the coffin. From the car, Fonsie could see the torturous ascent of the cortege: 'he found the coffin and the small band of toiling mourners unbearably moving as it made its low stumbling climb up the hill, and this deepened further his irritation and the sense of complete uselessness' (p. 399). There is something poignant about Fonsie's disability, his dependency on Philly, his loathing of his infirmity. He knows that the funeral has changed Philly and he can see why. Nevertheless he remonstrates with him that it is not respect for the dead that inspires the people around Gloria Bog: 'Oh, it's easy to honour the dead. It doesn't cost anything and it gives them a chance to get out of their bloody houses before they start to eat each other within' (p. 404). He could endure the thought of Philly going to the oil rigs, safe in the knowledge that he would always return. But the announcement after the funeral that he intends to buy Peter's house and farm from their mother, who will inherit everything, fills Fonsie with dread. On their way home, Philly tells his brothers:

'I felt something I never felt when we left the coffin on the edge of the grave. A rabbit hopped out of the briars a few yards off. He sat there and looked at us as if he didn't know what was going on before he bolted off. You could see the bog and all the shut houses next to Peter's below us. There wasn't even a wisp of smoke coming from any of the houses. Everybody gathered round, and the priest started to speak of the dead and the Mystery and the Resurrection.' (p. 404) 
What makes 'The Country Funeral' a masterpiece of short fiction writing is the subtle manner in which the customs and practices of a specific part of rural Ireland are conveyed. Centuries of respect for the dead, of gentle, supportive neighbourliness in times of distress, of remembering and commemorating a life just ended, are what render Gloria Bog and its inhabitants so precious in Philly's eyes. He is also aware that his own roots lie in this soil, perhaps because of his mother and their summer visits, through his uncle and those with whom he shared his frugal life. The decision to return here is not too shocking when considered in this context. In fact, Philly is one of a number of McGahern's characters who make their way back to what they think of as their primordial home. At the end of The Pornographer, the young protagonist similarly takes the decision to settle on the farm his parents left him in the west of Ireland after years of unbridled debauchery in Dublin. It is no coincidence that the nurse with whom he wishes to spend his life there is also from the country and he associates her with the smell of freshly cut hay. His friend Maloney is aghast at what he regards as a retrograde step. How could anyone bury himself in the country where religious bigotry and ignorance were rife?

'Look at today - isn't the whole country going around in its coffin! But show them a man and a woman making love - and worst of all enjoying it - and the streets are full of "Fathers of eleven", "Disgusted" and the rest of them. Haven't I been fighting it for years, and giving hacks like you employment into the bargain.' (p. 249)

Trapped in a loveless marriage, wealthy editor of pornographic publications, failed poet, Maloney is someone who needs to rail against what he views as a repressed Irish society governed by priests and pious politicians. Just as Fonsie fears losing Philly, Maloney does not want to lose his friend on account of this new vocation he senses in him after the burial of his aunt. McGahern, while remaining at a remove from the Catholicism in which he was reared, would always maintain respect for the positive aspects of Catholic rituals. Like the social rituals, the Church ceremonies have centuries of history behind them. Philly, a 'rough unfinished man', and the pornographer, who refuses to see the child he has fathered with a bank official and is described as a 'wastrel and a corrupter with a priest's 
face' (p. 214) by Maloney, are both somehow better, more fulfilled men when placed among their own people. The pornographer's loving care of his aunt when she is dying contrasts sharply with his shabby treatment of Josephine, the mother of his child. His epiphany at the end of the novel is the result of his knowledge that true happiness is found in the security of loving and being loved. He can achieve that with the nurse, living in close proximity to his uncle and the land:

What I wanted to say was that I had a fierce need to pray, for myself, Maloney, my uncle, the girl, the whole shoot. The prayers could not be answered, but prayers that cannot be answered need to be more completely said, being their own beginning as well as end. (p. 252)

He has not suddenly found God, but he has achieved a type of self-knowledge that will help him to tackle the obstacles that are placed in his path and possibly to overcome them. He has experienced the freedom of sexual liberation, has tasted the forbidden fruit and paid the price. Now what he seeks is a peace that is not possible for him in Dublin. To realise his destiny, he needs to journey back to the well of knowledge, there since his youth, but invisible to his inexperienced eyes. (As McGahern wrote in his first novel, The Barracks: 'The road away becomes the road back.') ${ }^{11}$ His uncle knows that he doesn't need to travel to see the world - all existence is there in front of you if you have a will to see it. His aunt remarked in relation to the garden she kept so beautifully: 'I don't know. It's only after years that you get some shape on things, and then after all that you have to leave. It's comical. You want to go on and you can't.' (p. I44)

The reader may well be wondering what all this has to do with the issue of globalisation. Well, what I am attempting to demonstrate is how essential truths are contained in the apparently most mundane situations. The global and the local are inextricably linked, as McGahern memorably illustrated in his work. He once stated: 'I think that all good writing is local, and by local I don't differentiate between Ballyfermot and north Roscommon. 
If the writer gets his words right, he'll make that local scene universal., ${ }^{12}$ His two last novels, Amongst Women (1990) and That They May Face the Rising Sun (2002), with which we conclude this chapter, are perhaps the best illustrations of the merging of the local and the global.

Amongst Women is generally accepted as being McGahern's most accomplished work. It won the Irish Times/Aer Lingus Irish Fiction Prize, the Sunday Independent/Irish Life Arts Award and the Bank of Ireland and Hughes Award. It was also shortlisted for the Booker Prize. The writing is compact, the characterisation dexterous, and the level of emotion it aroused in people in many different countries bears witness to its global appeal. Fintan O'Toole wrote that the novel was 'completely Irish and highly universal. ${ }^{13}$ The story of Michael Moran, veteran of the Irish War of Independence, widowed father of five children, domineering and sometimes violent patriarch, farmer in the west of Ireland whose homestead is referred to as Great Meadow, definitely has a resonance that reaches out beyond national boundaries. So many people have known someone who resembles this disenchanted figure who, after waging a successful guerilla war campaign against the English forces, decides that he will transfer his full attention to the care (or military supervision) of his family. Eamonn Wall makes a pertinent claim in relation to the extent to which McGahern succeeded in encapsulating in a short, dense novel the evolution of a society:

Amongst Women is a mirror to the century - from the War of Independence to close to the present. Here is a work which functions both as a chronicle of the fortunes of the Moran family and also a chronicle of the fortunes of the nation in its progress through fifty years of change. ${ }^{14}$

I2 'Catholicism and National Identity in the Works of John McGahern' (interview), p. $8 \mathrm{I}$.

I3 Fintan O'Toole, 'Both Completely Irish and Universal', review of Amongst Women in The Irish Times, is September 1990.

I4 Eamonn Wall, 'The Living Stream: John McGahern's Amongst Women and Irish Writing in the I990s', in Studies, No. 88 (351), Autumn 1999, pp. 305-14, p. 305. 
Moran's ultimate ambition, that of keeping his family together, handing on the farm to one of his two sons, thus ensuring some sort of continuity, is undone by what emerges from his heroics as a freedom fighter. The War of Independence has not led to the secure and egalitarian State that Moran and his idealistic fellow-revolutionaries had hoped for. Early on, he laments: 'What did we get for it? A country, if you'd believe them. Some of our own johnnies in the top jobs instead of a few Englishmen. More than half my own family work in England. The whole thing was a cod.'15 This disillusionment is not shared by his former comrade-in-arms and junior officer, McQuaid, who visited him every year on Monaghan Day, the day in February when the fair took place in Mohill. The two would reminisce about the war while McQuaid drank whiskey and the daughters served up a splendid meal. This was an important occasion for everyone in Great Meadow and that is why the daughters, seeing that their father is beginning to slip into a dangerous lethargy, decide to resurrect it after a number of years in an effort to revive Moran's drooping spirits. What they fail to comprehend is that McQuaid and their father had had a major falling out the last time they met on Monaghan Day. Irritated at Moran's compulsion to be top dog at all costs, McQuaid broke the habit of years by announcing he would not be staying the night. Unlike Moran, his friend had done well in post-independence Ireland as a cattle dealer. He therefore no longer felt obliged to play a subordinate role. Getting into his Mercedes (a far less common sight in Ireland at that time than it is now), he uttered under his breath, but loudly enough to be heard: 'Some people just cannot bear to come in second' (p. 22). This is an obvious reference to the reversal of their fortunes since the war. Moran is aware that this heralds the end of an old and valued friendship but he will yield no ground because in a way he had always despised friendship; families were what mattered, more particularly that larger version of himself - his family; and while seated in the same scheming fury he saw each individual member slipping out of his reach' (p. 22).

I5 John McGahern, Amongst Women (London: Faber, 1990), p. 5. All subsequent references will be to this edition, with page numbers in parentheses. 
The daughters were unaware of this rift, just as they forgot the tension the day brought with it. In their mind, Monaghan Day 'had become large, heroic, blood-mystical, something from which the impossible could be snatched' (p. 2). The parallels with the ideals of the leaders of the 1916 leaders are not coincidental. The women in Moran's life (and these obviously include his second wife Rose whom he decided to marry soon after that fateful falling out with McQuaid) determinedly insist on excusing the tantrums and excesses of their father and husband. When the girls are questioned by Rose's mother about whether their father beats them, they immediately close ranks and say that they were punished in Great Meadow when they were bold, just like in any other house. The fact that their older brother Luke left home for London after a serious beating is conveniently forgotten or is explained by the fact that the son and father never got on. Moran assumes heroic qualities in the eyes of the adoring women in his life. However, soon after moving into Great Meadow, Rose notices the fear that sometimes takes hold of the girls:

Only when they dropped or rattled something, the startled way they would look towards Moran, did the nervous tension of what it took to glide about so silently show. [...] The violence Moran had turned on her (Rose) she chose to ignore, to let her own resentment drop and to join the girls as they stole about so that their presences would never challenge his. (p. 53)

When young Michael starts to mitch from school and travel around the country in a car with the returned emigrant Nell Morahan, whose father worked as a day labourer (a fact that makes the Morahans socially inferior to the Morans of Great Meadow), he is teeing up a confrontation with his father. Michael's escapades with this woman show the vast difference in moral values between father and son. Young Michael is grateful for Nell's expert sexual initiation but when Moran discovers that he has been skipping school to spend time with this woman, the scene is set for a showdown. At this stage, his three sisters have all left home and there is only Rose to protect the rebellious adolescent. What young Michael fails to grasp is his father's desire for the two of them to run the farm together: 
He had forgotten how good two people could be working together. A man working alone was nothing. If the boy wanted to come in with him the two of them could do anything. They could run this place like clockwork. They could in time even take over other farms, a dream he had once had about his eldest son: together they could take over everything. (p. 1०8)

Moran's tragedy is to see all his dreams for a happy future dashed by the tides of time over which he has no control. Luke works in the property business (the prop that supported the latter years of the Celtic Tiger, before it finally brought it down) in London and can see no way of returning to live in Ireland, and certainly not with his father. Likewise, Michael makes a life for himself in London, where he meets and marries a woman a good few years older than he, and works as an accountant. The daughters are the ones with the fiercest loyalty, but, try as they may, they cannot run the farm with their father. Moran shares some obvious traits with McGahern's own father, another autocratic veteran of the War of Independence who was prone to inflicting sudden physical violence and verbal assaults on his children. But the essential difference lies in the detached manner in which the writer allows us to see some redeeming qualities in Moran - qualities that are sparse to the point of invisibility in the father figure in Memoir. As he approaches the end of his life, Moran spends much time contemplating the meadow at the back of the house, which prompts Mona to say to Rose: 'He must see something there' (p. 179). Her female intuition has led Mona to believe that her father's preoccupation with the meadow is linked to his imminent death. The tragedy is that Moran does actually see the splendour that is all around just as he arrives on the threshold of death:

To die was never to look at all this again. It would live in others' eyes but not in his. He had never realized when he was in the midst of confident life what an amazing glory he was part of. (p. 179)

As he is being led back to the house by his wife and daughters, he comments: 'I never knew how hard it is to die' (p. 179). Years of struggling with the land had caused him to miss out on its beauty, never to appreciate its 'amazing glory'. At this point, Moran achieves a hard-won epiphany. While he has the capacity to horrify and fascinate readers in equal measure because 
of his obduracy and self-absorption, McGahern's character is also shown to have some redeeming qualities. He writes a letter to Luke in which he apologises for any hurt he may have caused him and he inspires huge love in Rose and his daughters. The human drama that is lived out within the confines of Great Meadow stands outside history to a certain extent. This aspect of the novel makes Fintan O'Toole's assessment profoundly valid:

You start off thinking that it [Amongst Women] is about Irish history, about a man that fought in the War of Independence and what happens to him afterwards. But you realize as you go on that it is about the absence of history, about the country that was not formed, the community that did not come into existence, the society that did not grow. ${ }^{16}$

Hence the gloomy vista at the end of the novel when 'a little man in a brown felt hat, old and stiff enough to have fought with Fionn and Oisin' removed and folded 'the worn flag' (p. 183) while two local politicians looked on the crowd assembled with 'undisguised contempt' (p. I83). Joe Cleary argues that while Moran's attitude is definitely one that 'refuses to acknowledge that anything at all positive emerged from the national struggle', and that there is 'no strong repudiation of Moran's assessment of either the national struggle or its outcome in the novel either. ${ }^{17} \mathrm{I}$ am not sure that McGahern would have seen his role as a novelist as one that obliged him to present an evaluation of historical events or their legacy. It is true that the image of post-independence Ireland presented in the novel is negative and harrowing, but the novel is narrated through the eyes of someone whose hopes have been dashed. I would incline more towards the assessment of Declan Kiberd who says that McGahern 'manages to be utterly faithful to his immediate world of Roscommon/Leitrim, yet by keeping the references to that region vague and sparing, he can treat of it as an everywhere. ${ }^{\prime 18}$

I6 O’Toole, 'Both completely Irish and Universal'. Emphasis in the original.

I7 Joe Cleary, Outrageous Fortune: Capital and Culture in Modern Ireland (Dublin: Field Day Publications, 2007), p. 222.

I8 Declan Kiberd, 'John McGahern's Amongst Women', in Maria Tymoczko and Colin Ireland (eds), Language and Tradition in Ireland: Continuities and Displacements 
That They May Face the Rising Sun, McGahern's last novel, allows us intimate access to a period in the lives of a community living around a lake in a setting that has more than a passing resemblance to the residence where McGahern and his second wife, Madeline, made their home when the couple decided to settle in Leitrim in the 1970s. He explains the choice in Memoir: "It was a time when we could have settled almost anywhere, and if she had not liked the place and the people we would have moved elsewhere. I, too, liked the place, but I was from these fields and my preference was less important. ${ }^{19}$ There are striking similarities between the setting and the characters presented and real life situations. But, as Memoir has revealed, facts, when recounted from memory, are always subject to artistic rearrangement. Certainly the returned emigrant Joe Ruttledge and his artistic wife Kate remind one of McGahern and his wife, especially in terms of their rather unconventional farming techniques. The local handyman Patrick Ryan says of the Ruttledges: 'There's an old Shorthorn they milk for the house that would nearly sit in an armchair and put specs on to read the Observer. ${ }^{\prime 20}$ There are also several examples of where fact and fiction diverge significantly. The mistakes made with the highly autobiographical The Leavetaking, where McGahern was too close to his subject and lacked that distance that is demanded of all good fiction, would not be repeated in his last novel. Having said that, I suspected from the nostalgic, gentle tone of the novel when it was first published that it would be McGahern's last work of fiction. I was thus less than surprised when it was followed a few years later by Memoir. Seamus Deane, in a review published in The Guardian, wrote:

The book is a strange and wonderful mixture of various genres of writing - narrative in the basic sense, but also a meditation, a memoir, a retrospect, an anthropological

(Amherst and Boston: University of Massachusetts Press, 2003), pp. 195-213, p. 199.

I9 John McGahern, Memoir (London: Faber, 2005), p. 2

20 That They May Face the Rising Sun (London: Faber, 2002), p. 76. All subsequent references will be to this edition, with page numbers in parentheses. 
study of a community ... a celebration of an Ireland that had formerly been the object of chill analysis as well as loving evocation. ${ }^{21}$

This novel recounts how a group of middle-aged to elderly people, living at a slight remove from the world all around them, exist in a sort of timeless zone where change is rare. Their support of one another is obvious in the way that the big-hearted Jamesie keeps a watchful eye on the Ruttledges' cow who is due to calve, or in how Patrick Ryan, a rough-tongued labourer, tells Joe that he will finish the shed that has been standing roofless for years. The death of his brother Edmund and close friend Johnny has shown Ryan that life is transient: 'We're going to finish that building. [...] It takes a hard jolt every now and again to learn us that we'll not be in it forever' (p. 297). The same man announced early in the novel: 'After us there'll be nothing but the water hen and the swan' (p. 45). Jamesie's wife Mary makes an analogous comment: 'We're not more than a puff of wind out on the lake' (p. IIs). This elegiac tone is palpable throughout the novel as the community comes to terms with the fact that they are likely to be the last of their kind. Other people may well come to live in the area, but they will not be the same type of people; they will not share the same belief system, the same values. In terms of the impact of globalisation, it can be seen that the houses around the lake are not in a time warp when it comes to having access to modern domestic appliances like dishwashers and televisions, or up-to-date agricultural machinery like tractors and bailing machines. This does not change the essential ingredients of the people's lives, though. They are still committed to the traditional ideals, particularly neighbourliness. Scarcely a day goes by but Jamesie travels around the lake to visit the Ruttledges, sometimes just to chew the cud, at other times to help them out on the farm. When his vigilance saves the cow and her calf, Ruttledge describes him as 'an angel of the Lord' (p. 53). In return, Ruttledge drives over in his tractor to help his friend with turning and bailing the hay. He also assists him with writing to his brother Johnny, a long-time emigrant in England, who announces that he is thinking of returning to

2I Seamus Deane, 'A New Dawn', review of That They May Face the Rising Sun in The Guardian, I2 January 2002. 
live in Ireland for his retirement. The thought of Johnny living with them on a permanent basis fills Jamesie and Mary with dread, but they are at a loss as to how to convey this to him:

They could not live with him and they could not be seen - in their own eyes and in the eyes of others - to refuse him shelter or turn him away. The timid, gentle manners, based on a fragile interdependence, dealt in avoidances and obfuscations. Edges were softened, ways found round harsh realities. What was unspoken was often far more important than the words that were said. (p. I86)

This scene is beautifully observed by a writer who understands his characters and what motivates them. Social convention would demand you never refuse a bed to a close relative and yet such a situation would be disastrous for all involved. In the end, Johnny decides to stay on in England and so the situation they so dreaded never arises, but their gratitude for Ruttledge's letter explaining their uneasiness about the proposed move is deep and long-lasting. Although Johnny is a relatively minor figure in the novel, arriving home for a few weeks' holiday at the beginning of every summer, being collected by his brother from the train station, visiting the same people to whom he says the same things, declaring everything to be 'alphabetical', his word for perfect, he is nonetheless central to some of the most important episodes in the book. After a day out with Ruttledge, where his prowess as a darts player gains huge admiration in a local pub, Johnny dies peacefully, probably as a result of a massive heart attack. In the absence of Patrick Ryan, who cannot be contacted, Ruttledge is asked to lay out his corpse. This act assumes a spiritual connotation:

The rectum absorbed almost all of the cotton wool. The act was as intimate and warm as the act of sex. The innate sacredness of each single life stood out more starkly in death than in the whole of natural life. To see him naked was also to know what his character and clothes had disguised - the wonderful physical specimen he had been. (p. 273)

As we have already noted in relation to 'A Country Funeral', McGahern's treatment of the rituals surrounding death is always surefooted and respectful. When describing later to Kate how he was affected by the incident, Ruttledge explains: 'It made death and the fear of death more natural' 
(p. 279). Later, as they are digging Johnny's grave, Patrick Ryan tells Ruttledge that the head must lie facing the west for one simple reason: 'So that when he wakes he may face the rising sun. [...] We look to the resurrection of the dead' (p. 282) The Catholic and pagan are wonderfully fused in this description: the worship of the sun being combined with a belief in the resurrection of the dead. In a way, living as they do in such close proximity to nature, it is difficult for the inhabitants of this area to escape from its influence. There are several detailed depictions of the beauty of the landscape which a man like Ruttledge, living a more leisurely existence than Moran, has time to appreciate:

A pair of herons moved sluggishly through the air between the trees of the island and Gloria Bog. A light breeze was passing over the sea of pale sedge like a hand. The blue of the mountain was deeper and darker than the blue of the lake or the sky. Along the high banks at the edge of the water there were many little private lawns speckled with fish bones and blue crayfish shells where the otters fed and trained their young. (p. 42)

Passages like this cannot be faked. They require an experienced eye, as well as a sympathetic understanding of the workings of nature. Like Moran before him, Ruttledge knows that death means severing one's links with a material world that is mysterious and entrancing, with people who are on the whole decent and supportive, with a life whose seemingly repetitive and empty rhythms often reveal hidden meanings. For Denis Sampson, the myriad of references to the lake, the homes dotted around it and their inhabitants are there because 'at the centre of his [McGahern's] poetic interest here is the relationship between transient human habitations and the natural contours of the landscape in which they are situated. ${ }^{22}$ Towards the end of the novel, Jamesie states: 'I may not have travelled far but I know the whole world' (p. 296), a comment that echoes the observation by Maloney quoted earlier in relation to the pornographer's uncle. At the conclusion of the book, the telephone poles erected around the lake, occluding the view, Sun', in the Irish University Review (special John McGahern issue), ed. John Brannigan, 35:1, Spring/Summer 2005, pp. 136-46, p. 138. 
are a reminder that the community, just after burying one of their own, Johnny, face a precarious future. The sense of place, so strongly embedded in people like Ruttledge, his uncle 'The Shah', Jamesie, Mary, Patrick Ryan cannot resist the inroads of globalisation indefinitely. Like Heaney, McGahern was attuned to the musicality of place names: Aughawillan, Cootehall, Ardcarne, Dromod, Carrick-on-Shannon, Oakport assume a sort of incantatory quality similar to prayer in his work. Often, as characters make their way back to Dublin by train, they make a mental note of the towns they pass through as if in an effort to gauge the distance they are travelling from their roots. The naming of the trees, plants and wildlife of Leitrim in Memoir serves a similar purpose. In a period when the effects of globalisation assail us from every angle, McGahern's writings remind us that two or three hours away from the gridlock of Dublin traffic and the frenetic world of Temple Bar and what remains of the Celtic Tiger, there still exists a rural Ireland which has remained largely intact, although fragile. Even when it is not possible to physically live in such an environment, we can experience it by reading McGahern's recreation of what Heaney has referred to as a 'country of the mind.' It seems appropriate to end this collection with the words of the Nobel Laureate and close friend of McGahern:

Irrespective of your creeds or politics, irrespective of what culture or subculture may have coloured our individual sensibilities, our imaginations assent to the stimulus of the names, our sense of place is enhanced, our sense of ourselves as inhabitants not just of a geographical country but of a country of the mind is cemented. ${ }^{23}$

23 Seamus Heaney, 'The Sense of Place', in Preoccupations: Selected prose 1968-78 (London: Faber, I980), p. 132. 



\section{Notes on Contributors}

Michael Cronin holds a Personal Chair in the Faculty of Humanities and Social Sciences at Dublin City University. He is author of Translating Ireland: Translation, Languages and Identity (1996); Across the Lines: Travel, Language, Translation (2000); Translation and Globalization (2003); Time Tracks: Scenes from the Irish Everyday (2003); Irish in the New Century/ An Ghaeilge san Aois Nua (2005); Translation and Identity (2006); The Barrytown Trilogy (2007); and Translation goes to the Movies (2008). He is co-editor of Tourism in Ireland: A Critical Analysis (1993); Anthologie de nouvelles irlandaises (1997); Unity in Diversity? Current Trends in Translation Studies (1998); Reinventing Ireland: Culture, Society and the Global Economy (2002); Irish Tourism: Image, Culture and Identity (2003); The Languages of Ireland (2003). Transforming Ireland, co-edited with Peadar Kirby and Debbie Ging will be published in spring 2009. He is a Member of the Royal Irish Academy and co-editor of The Irish Review.

ANNE fOGARTY is Professor of James Joyce Studies at University College Dublin and President of the International James Joyce Foundation. She is Director of the UCD James Joyce Research Centre and editor of the Irish University Review. She is co-editor with Timothy Martin of Joyce on the Threshold (2005), with Morris Beja of Bloomsday Ioo: Essays on Ulysses and with Luca Crispi of Dublin James Joyce Journal, No. I (2008). She is currently completing a study of the poetry of Eavan Boland and a monograph on the socio-historical contexts of Ulysses, entitled James Joyce and Cultural Memory: Reading History in Ulysses. She is the recipient of the 2008 Charles Fanning Award for excellence in Irish studies.

TOM HERRON is Lecturer in English and Irish Literature in the School of Cultural Studies at Leeds Metropolitan University. He is the co-author (with John Lynch) of After Bloody Sunday: Representation, Ethics, Justice 
(2007). His edited collection of poetry, The Harrowing of the Heart (coedited with Julieann Campbell) was launched in Derry's Guildhall on 30 January 2008 to mark the thirty-sixth anniversary of Bloody Sunday. He was the editor of the new edition of Louis MacNeice's I Crossed the Minch (2007), and is currently working on two book projects: The Other Capital - Irish Writing London, and The Good March: a History of Bloody Sunday commemoration.

TOM INGLIS has written extensively on the cultural transformation of Ireland concentrating primarily on religion, identity and sexuality. His recent book Global Ireland: Same Difference (2008) is a study of how everyday life in Ireland has become globalised and how Irish difference has been maintained. His other books include Truth, Power and Lies: The Case of the Kerry Babies (2003), Lessons in Irish Sexuality (1998) and Moral Monopoly: The Rise and Fall of the Catholic Church in Modern Ireland (2nd edn, 1998). He is an Associate Professor in the School of Sociology at University College Dublin.

PEADAR KIRBy is Professor of International Politics and Public Policy in the Department of Politics and Public Administration, University of Limerick. His latest book is Contesting the State: Lessons from the Irish Case, co-edited with Maura Adshead and Michelle Millar (2008) and he has two books forthcoming in 2009: Power, Dissent and Democracy: Civil Society and the State in Ireland, co-edited with Deiric Ó Broin, and Transforming Ireland: Challenges, Critiques and Resources, co-edited with Debbie Ging and Michael Cronin. He is author of Explaining Ireland's Development: Economic Growth with Weakening Welfare, Social Policy and Development Paper No. 37, published in 2008 by the United Nations Research Institute for Social Development (UNRISD) as part of its research project on poverty reduction and policy regimes. He has published extensively on international development and globalisation, especially in Ireland and Latin America. Among his other books are Taming the Tiger: Social Exclusion in a Globalised Ireland, co-edited with David Jacobson and Deiric Ó Broin (2006), Vulnerability and Violence: The Impact of Globalisation (2006), Introduction to Latin America: Twenty-First Century Challenges (2003), 
The Celtic Tiger in Distress: Growth with Inequality (2002), Reinventing Ireland: Culture, Society and the Global Economy, co-edited with Luke Gibbons and Michael Cronin (2002) and Poverty Amid Plenty: World and Irish Development Reconsidered (1997).

PATRICK LONERGAN lectures at the National University of Ireland, Galway. He writes about theatre for The Irish Times and Irish Theatre Magazine, and his books include Globalization and Theatre: Irish Drama in the Celtic Tiger Era (2008), The Methuen Drama Anthology of Irish Plays (2008), and (with Nicholas Grene), Interactions: the Dublin Theatre Festival, 1957-2007 (2008). He is Academic Director of the Synge Summer School.

CATHe Rine Maignant is Professor of Irish Studies at the University of Lille and President of the French Association for Irish Studies. After writing a $\mathrm{PhD}$ on early medieval Irish Christianity, she now specialises in contemporary Irish religious history. Her research interests include the new religious movements, the response of the Catholic Church to secularisation, interreligious dialogue, Celtic Christianity and the religious aspects of globalisation.

EAMON MAHER is Director of the National Centre for Franco-Irish Studies at the Institute of Technology, Tallaght, where he also lectures in humanities. Recent monographs include Jean Sulivan (1913-1980): La marginalité dans la vie et l'oeuvre (2008) and John McGahern: From the Local to the Universal (2003). He edits the series Reimagining Ireland and Studies in Franco-Irish Relations for the Peter Lang Publishing Group. He is currently working on a second monograph on John McGahern entitled 'The Church and its Spire': John McGahern and the Catholic Question.

WILLY MALEY is Professor of Renaissance Studies at the University of Glasgow, and Visiting Professor in Irish Studies at the University of Sunderland. He is the author of $A$ Spenser Chronology (1994), Salvaging Spenser: Colonialism, Culture and Identity (1997), Nation, State and Empire in English Renaissance Literature: Shakespeare to Milton (2003), and Muriel Spark for Starters (2008). He is editor, with Andrew Hadfield, of $A$ View of the Present 
State of Ireland: From the First Published Edition (1997). He has also edited five collections of essays: with Brendan Bradshaw and Andrew Hadfield, Representing Ireland: Literature and the Origins of Conflict, I534-I660 (1993); with Bart Moore-Gilbert and Gareth Stanton, Postcolonial Criticism (1997); with David J. Baker, British Identities and English Renaissance Literature (2002); with Andrew Murphy, Shakespeare and Scotland (2004); and with Alex Benchimol, Spheres of Influence: Intellectual and Cultural Publics from Shakespeare to Habermas (Peter Lang, 2006). Work in progress includes a monograph on Milton's History of Britain and several edited collections, including Shakespeare and Wales, Shakespeare and England, and The Edinburgh Companion to Spark, as well as the proceedings of the Annual Conference of the Society for the Study of Nineteenth-Century Ireland held in Glasgow in 2007, Romantic Ireland: From Tone to Gonne (2 vols), co-edited with Paddy Lyons.

GRACE NEVILLE is Vice-President for Teaching and Learning at University College Cork (National University of Ireland). She studied at UCC, the Université de Caen and the Université de Lille 3. She taught at the Université de Lille 3 and the Université de Metz before her appointment at UCC. Her research and publication areas include Franco-Irish studies, women's studies and language legislation in France.

EUGENE O'BRIEN is Senior Lecturer, Head of the Department of English Language and Literature and Director of the MIC Irish Studies Centre at Mary Immaculate College, Limerick. His publications include: The Question of Irish Identity in the Writings of William Butler Yeats and James Joyce (1998); Examining Irish Nationalism in the Context of Literature, Culture and Religion: A Study of the Epistemological Structure of Nationalism (2002); Seamus Heaney - Creating Irelands of the Mind (2002); Seamus Heaney and the Place of Writing (2003); Seamus Heaney: Searches for Answers (2003). He co-edited: La France et la Mondialisation/France and the Struggle against Globalization (Peter Lang, 2007); Reinventing Ireland Through a French Prism (Peter Lang, 2007) and Modernity and Postmodernity in a FrancoIrish Context (Peter Lang, 2008). His monograph 'Kicking Bishop Brennan 
up the Arse': Negotiating Texts and Contexts in Contemporary Irish Studies has recently been published by Peter Lang.

Alison O'MALley-YOUnger is Senior Lecturer in English and Drama at the University of Sunderland. With John Strachan, she founded the annual Irish studies conferences at Sunderland in 2002 and she is Director of the North-East Irish Culture Network. She has published in the fields of contemporary critical theory and women's writing in Ireland and Irish Drama, both contemporary and nineteenth-century. Her current projects include Essential Criticism: Brian Friel and an edited collection with John Strachan entitled, Ireland at War and Peace. She has edited, with Frank Beardow, Representing Ireland: Past, Present and Future (2005), with John Strachan, Essays on Modern Irish Literature (2007) and with Paddy Lyons, No Country for Old Men: Fresh Perspectives on Irish Literature (Peter Lang, 2009). She is currently researching notions of heroic masculinity in nineteenth-century patriotic melodrama in Ireland and, with John Strachan and John Nash, is working on a Leverhulme-funded major research project entitled 'Consumer Culture, Advertising and Literature in Ireland I848-1904' and with Claire Nally on an edited collection entitled Naked Exhibitionism: Women, Performance and Public Exposure from the Medieval to the Present.

FINTAN O'TOOLE is Assistant Editor of The Irish Times and has been drama critic of In Dublin Magazine, The Sunday Tribune, The Irish Times and the New York Daily News. His most recent books are White Savage: William Johnson and the Invention of America (2005) and, with Shane Hegarty, The Irish Times Book of the 1916 Rising (2006). 



\section{Index}

Abbey Theatre, I77, I79, I80, 183

altericide, 17

America, 2, 103, 104, 137, 291, 234, 237

Andrews, Elmer, I54

Ang, Ien, 150

Appadurai, Arjun, 75, 76, 77, 82, I21, I22, I25, 136

Austen, Jane, 212

Barry, Sebastian, xii, I81, I82

Baudrillard, Jean, I70, I7I

America, 170

Bauman, Zygmunt, I83

Beckett, Samuel, I85, I87, I88, 212

Bhabha, Homi, I50

Booker, Keith, I2, 206, 222

Boucicault, Dion, I85, 186

Bourdieu, Pierre, 76, I25, I27

Braidotti, Rosi, 82, 89, 92, 160

Brand, Steward, 29

Carr, Marina, I79, I8I, I82

Carson, Ciaran, 194

Casanova, Pascale, 24

Catholic Church, xiii, 4, 37, 93, 106, 107, 108, 109, 196, 213, 234, 235

Catholicism, 38, 94, 98, 106, 107, 108, 109, I 44, 2I2, 2I3, 220, 222

Celtic Tiger, vii, viii, 3, 4, 27, 53, 54, 55, 57, $59,60,61,63,65,74,93,107,108$, II9, I33, I80, I82, I83, I85, I86, I90, 191, 193, 209, 21I, 215, 225, 231, 235

Cleary, Joe, 4, 226 communication, 34, 70, 7I, 73, 85, 88, 136, 150

Critchley, Simon, 67

Cronin, Michael, 6, II, I8, I33, 234, 235

cyber space, 88

Dantanus, Ulf, I6I

Daukantas, Simonas, vii

Deane, Seamus, 6, 160, I64, I91, 193, 195, 204, 205, 206, 208, 227, 228

Reading in the Dark, 193, 204, 205, 206, 208

deconstruction, 69, 78, 87

Deleuze, Gilles and Guattari, Félix, I54, I57, I59, I6I

Derrida, Jacques, 35, 52, 68, 69, 70, 78, 79, 8I, 87, 91, I37, I46, I95, 207

difference, 25, 75, 89, IIO, II 4, I33, 234

dinnseanchas, 162

Docherty, Thomas, 162, 163, 192

Doyle, Roddy, 6, I33, I34, I40, I4I, I42, I43, I9I, 193, 197, 199, 200, 204, 205, 206, 207

Paddy Clarke Ha Ha Ha, 204

The Deportees, I33, I34, I40, I4I, I42

During, Simon, I17, I19, I2I, 192

dwelling, I5, 23

economics, 75, 95, I03, I33, 179, I86, I87, 233,235

Ennis, Seamus, II

Enright, Anne, I2, I4, 16, 26, 29, 133, 134, I $43,144,146$ 
The Gathering, I2, I4, I33, 134, I43, I 44, I 45, I 46

ethics, I28, 233

Fagan, Honor, 73, 74, 191

Fennell, Desmond, 169

financial transactions, 5,72

Freud, Sigmund, I7I

Friel, Brian, 6, 7, I49, I50, I51, I52, I53, I54, I59, I60, I6I, I62, I8I, I86, 237

future, xi, I6, I8, 26, 27, 28, 29, 33, 36, 40, $42,43,45,50,51,58,59,68,72$, 78, 94, IOI, III, I42, I54, I64, I76, 225, 231

Gaffney, Maureen, 20, 2I

Gibbons, Luke, 133, 195, 235

Giddens, Anthony, 5, 97, 116

Goethe, Johann Wolfgang von, 179, I82

government, vii, 2, 3, 20, 56, 71, 72, 73, 78, 97, 184, 187

GPS (Global Positioning System), 71, 87, $88,89,90$

Graham, Brian, I49

Grene, Nicholas, I52, I59, I6I, 235

Grewal, Inderpal, 137

Guattari, Félix see Deleuze, Gilles

habitus, 71, 76, 77, 83, 85, I15, I22, I24, I25, I26, I27, 130

hauntological, 72, 75, 76

Heaney, Hugh, 167

Heaney, Seamus, 6, 7, I49, I50, I51, I52, I59, I62, I63, I64, I65, I66, 167, I68, I69, I70, 171, 172, 173, 174, 175, 176, 203, 205, 231, 236

Heidegger, Martin, 8I, I49, I64

history, 29, 74, 119, 215, 233, 234, 236

information, 2I, 8I

Ingold, Tim, I5, 23
Jordan, Neil, I8I, 201, 202

Joyce, James, X, I85, 193, I94, 195, I96, I97, 203, 205, 212, 233, 236

Julien, François, I 8

Kavanagh, Patrick, 192, 193, 212

Keogh, Dermot, viii

Kiberd, Declan, 191, 226

Kirby, Peadar, 2, 3, 93, 96, 97, 108, 133, 233

knowledge, 70, 215

Komito, Lee, vii

Laval, Christian, 22

Le Faye, Deirdre, $2 \mathrm{I} 2$

Levinas, Emmanuel, I4I

Lloyd, David, I63, 195

Lonergan, Patrick, I33, I77, I83, I84

Longley, Michael, 168

MacLaverty, Bernard, 194, 212

Mahon, Derek, I68, 174, 193

Maître, Bernard, 27

Marlowe, Christopher, 178, I80

McCabe, Patrick, 6, 191, 193, 201, 202, 203, 204, 205, 206, 207

The Butcher Boy, 193, 198, 201, 202, 204, 205

McCann, Colum, 6, I33, I34, I37, I38, I39, I 40

Zoli, 133, 134, I37, 138, I39, 140

McCartney, Colum, 167

McDonagh, Martin, I8I, I82, I84

McGahern, John, 6, 7, 207, 211, 212, 213, $214,215,216,217,220,221,222$, 225, 226, 227, 229, 230, 231, 235

Amongst Women, 222, 223, 226

That They May Face the Rising Sun, 216, 222, 227, 228

The Barracks, 214, 221

The Dark, 207, 216

The Pornographer, 215, 220 
McGrew, Anthony, 134, 135

McGuckian, Medbh, I64, I67

McGuinness, Frank, I81, I82, 196

McPherson, Conor, 6, I77, I78, 179, I80, I8I, I82, I83, I85, I86, I88, I89, 190

McWilliams, David, I6, 20

memoir, 225, 227, 23I

mnemotechnics, 84

mobile phones, $68,71,75,83,84,90$

mobile technology, 67, 71, 74, 75, 76, 8I, $82,83,84,87,89,9 \mathrm{I}$

'muintir', I2, I3, I4

Mulcahy, Orna, xii

Muldoon, Paul, I56, I63, I64, 174

Murphy, Tom, 73, 74, 75, 77, 179, I81, I82, 236

Nietzsche, Friedrich, 156, I6I

The Birth of Tragedy, $16 \mathrm{I}$

Nolan, Brian, 27

nomadic subject, 89

Northern Ireland, xi, 74, II

Nugent, Ciaran, I44, I45, I46, I66, 20I, 202, 205

O’Crohan, Seán, x

O'Crohan, Tomás, $\mathrm{x}, 2 \mathrm{I} 2$

Ó Cróinín, Dáibhí, 29

Ó Searcaigh, Cathal, 169

Ó Treasaigh, Lorcán, I2, I3, 16, 26, 29

Cnoc na Lobhar, 12

O'Brien, Sean, 163

Other, $18,19,56,75,77,83,85,142,146$,

$$
\text { I72, } 192,228,234
$$

Otherness, $\mathrm{X}, \mathrm{I3} 4, \mathrm{I3} 9, \mathrm{I} 4 \mathrm{I}, \mathrm{I} 45, \mathrm{I} 46$

Papusza (Bronislawa Wajs), 138

personal, 5, II3, II7, 233

Pierce, David, 215
Pine, Joseph and Richard Gilmore, I86, I87 postmodernism, 163,192

Pratt, Mary Louise, 23

race, $\mathrm{x}, 37, \mathrm{I} 42$

Rebellato, Dan, I84

Reith Lecture, 1994 (Marina Warner), 176

religion, 37, 50, 93, 98, 99, 100, 103, 105, 236

revisionism, 195

Riverdance, 188

Robinson, Tim, 22, 25, 26, 85

Sampson, Denis, 230

Sassen, Saskia, I35, 136

science, I9I

secularisation, 74, 99, I05, IIO

self, 5, 52, 67

Sheridan, R.B., I85

SMS messages, 82, 85, 90

Smyth, Gerry, 197, 198, 209

The Novel and the Nation, 197, 198, 209

Starbucks, I87

Swift, Jonathan, I85, 203

symbolism, 81, 82

Synge, John Millington, I85, 204, 235

techné, $8 \mathrm{I}$

technology, 6, 70, 79, 87, 235

Tomlinson, John, I13, 136, 137

Torga, Miguel, 6, 211, 212

transnationalism, 137

Turner, Victor, I50, 154

United States Army Air Force, 173

Urry, John, 24, 25, 170

the tourist gaze, 170 
Vattimo, Gianni, 83

Veronica, St, I3, I4, I7, 26, I44, I45, I46

Virilio, Paul, 79, 80, 8I

vulnerability, 93, 96, 97, 234
Wall, Eamonn, 222

Walsh, Enda, I8I, I82

Warner, Marina, 176

Williams, Raymond, 204 


\section{Reimagining Ireland}

Series Editor: Dr Eamon Maher, Institute of Technology, Tallaght

The concepts of Ireland and 'Irishness' are in constant flux in the wake of an ever-increasing reappraisal of the notion of cultural and national specificity in a world assailed from all angles by the forces of globalisation and uniformity. Reimagining Ireland interrogates Ireland's past and present and suggests possibilities for the future by looking at Ireland's literature, culture and history and subjecting them to the most up-to-date critical appraisals associated with sociology, literary theory, historiography, political science and theology.

Some of the pertinent issues include, but are not confined to, Irish writing in English and Gaelic, Nationalism, Unionism, the Northern 'Troubles', the Peace Process, economic development in Ireland, the impact and decline of the Celtic Tiger, Irish spirituality, the rise and fall of organised religion, the visual arts, popular cultures, sport, Irish music and dance, emigration and the Irish diaspora, immigration and multiculturalism, marginalisation, globalisation, modernity/postmodernity and postcolonialism. The series publishes monographs, comparative studies, interdisciplinary projects, conference proceedings and edited books.

Proposals should be sent either to Dr Eamon Maher at eamon.maher@ ittdublin.ie or to Joe Armstrong, Commissioning Editor for Ireland, Peter Lang Ltd, P.O. Box 38, Kells, County Meath, +353 (0) 46924 9285, joearmstrong@eircom.net.

Vol. 1 Eugene O'Brien: 'Kicking Bishop Brennan up the Arse': Negotiating Texts and Contexts in Contemporary Irish Studies ISBN 978-3-03911-539-6. 219 pages. 2009.

Vol. 2 James P. Byrne, Padraig Kirwan and Michael O'Sullivan (eds): Affecting Irishness: Negotiating Cultural Identity Within and Beyond the Nation

ISBN 978-3-03911-830-4. 334 pages. 2009. 
Vol. 3 Irene Lucchitti: The Islandman: The Hidden Life of Tomás O'Crohan

ISBN 978-3-03911-837-3. 232 pages. 2009.

Vol. 4 Paddy Lyons and Alison O'Malley-Younger (eds): No Country for Old Men: Fresh Perspectives on Irish Literature ISBN 978-3-03911-841-0. 289 pages. 2009.

Vol. 5 Eamon Maher (ed.): Cultural Perspectives on Globalisation and Ireland ISBN 978-3-03911-851-9. 256 pages. 2009.

Vol. 6 Lynn Brunet: 'A Course of Severe and Arduous Trials': Bacon, Beckett and Spurious Freemasonry in Early TwentiethCentury Ireland ISBN 978-3-03911-854-0. 218 pages. 2009.

Vol. 7 Claire Lynch: Irish Autobiography: Stories of Self in the Narrative of a Nation ISBN 978-3-03911-856-4. 234 pages. 2009.

Vol. 8 Victoria O'Brien: A History of Irish Ballet, 1927-1963 ISBN 978-3-03911-873-1. Forthcoming.

Vol. 9 Irene Gilsenan Nordin and Elin Holmsten (eds): Liminal Borderlands in Irish Literature and Culture ISBN 978-3-03911-859-5. 208 pages. 2009.

Vol. 10 Claire Nally: Envisioning Ireland: W.B. Yeats's Occult Nationalism ISBN 978-3-03911-882-3. Forthcoming.

Vol. 11 Raita Merivirta: 'Trying to take the Gun out of Irish Politics': Neil Jordan's Michael Collins: Examining National History and Reimagining Irishness on Screen ISBN 978-3-03911-888-5. Forthcoming.

Vol. 12 John Strachan and Alison O'Malley-Younger (eds): Ireland: Revolution and Evolution ISBN 978-3-03911-881-6. Forthcoming. 
Vol. 13 Barbara Hughes: Between Literature and History: The Diaries and Memoirs of Mary Leadbeater and Dorothea Herbert ISBN 978-3-03911-889-2. Forthcoming.

Vol. 14 Edwina Keown and Carol Taaffe (eds): Irish Modernism:

Origins, Contexts, Publics

ISBN 978-3-03911-894-6. Forthcoming.

Vol. 15 John Walsh: The Irish Language and Ireland's Development ISBN: 978-3-03911-914-1. Forthcoming.

Vol. 16 Michelle Woods: Ernest Gébler: The Unlikely Irishman ISBN: 978-3-03911-926-4. Forthcoming.

Vol. 17 Susan Cahill and Eóin Flannery (eds): This Side of Brightness: Essays on the Fiction of Colum McCann ISBN: 978-3-03911-935-6. Forthcoming.

Vol. 18 Brian Arkins: The Thought of W.B. Yeats ISBN: 978-3-03911-939-4. Forthcoming. 
